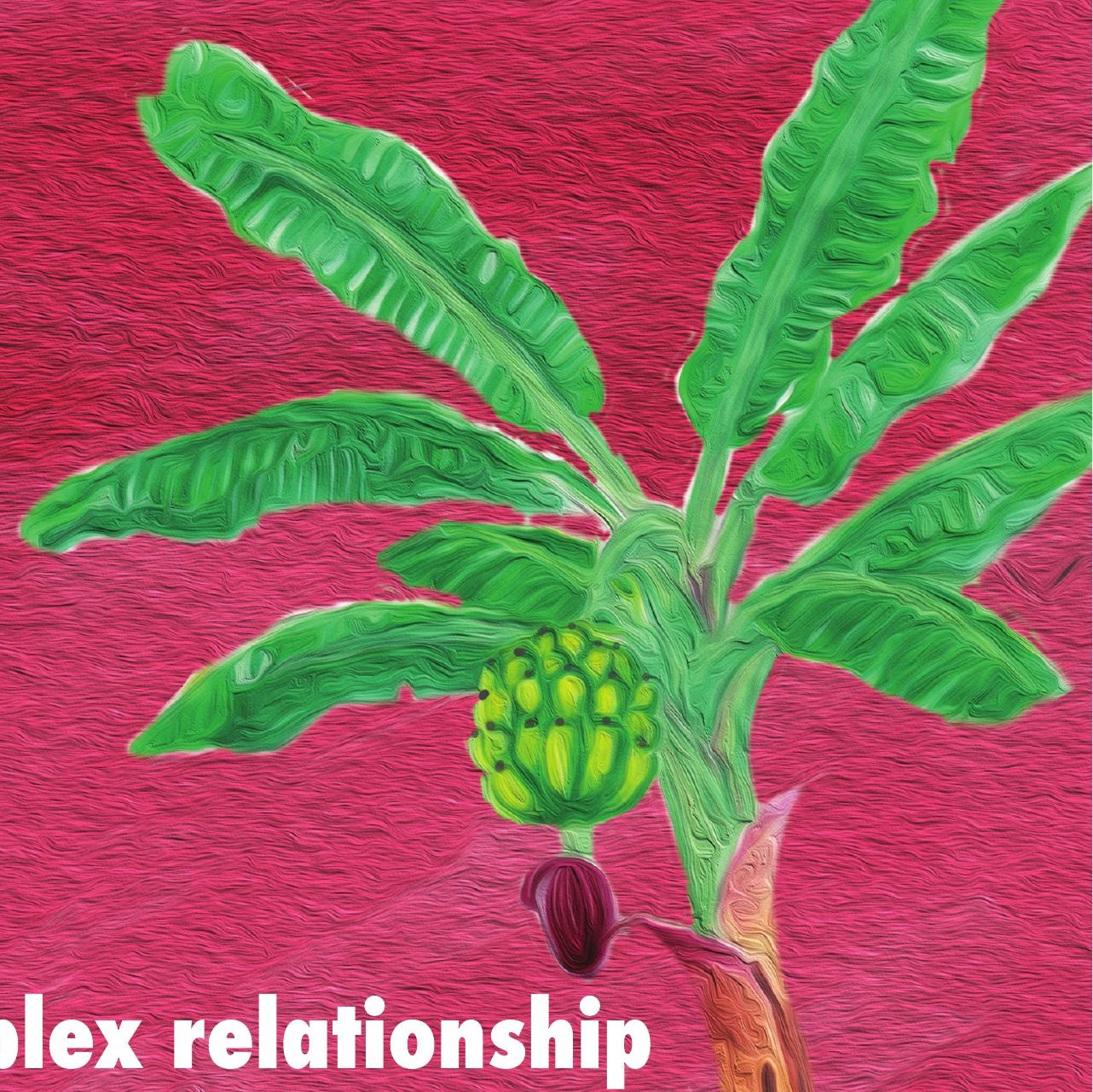
Banana \& Fusarium wilt in Indonesia

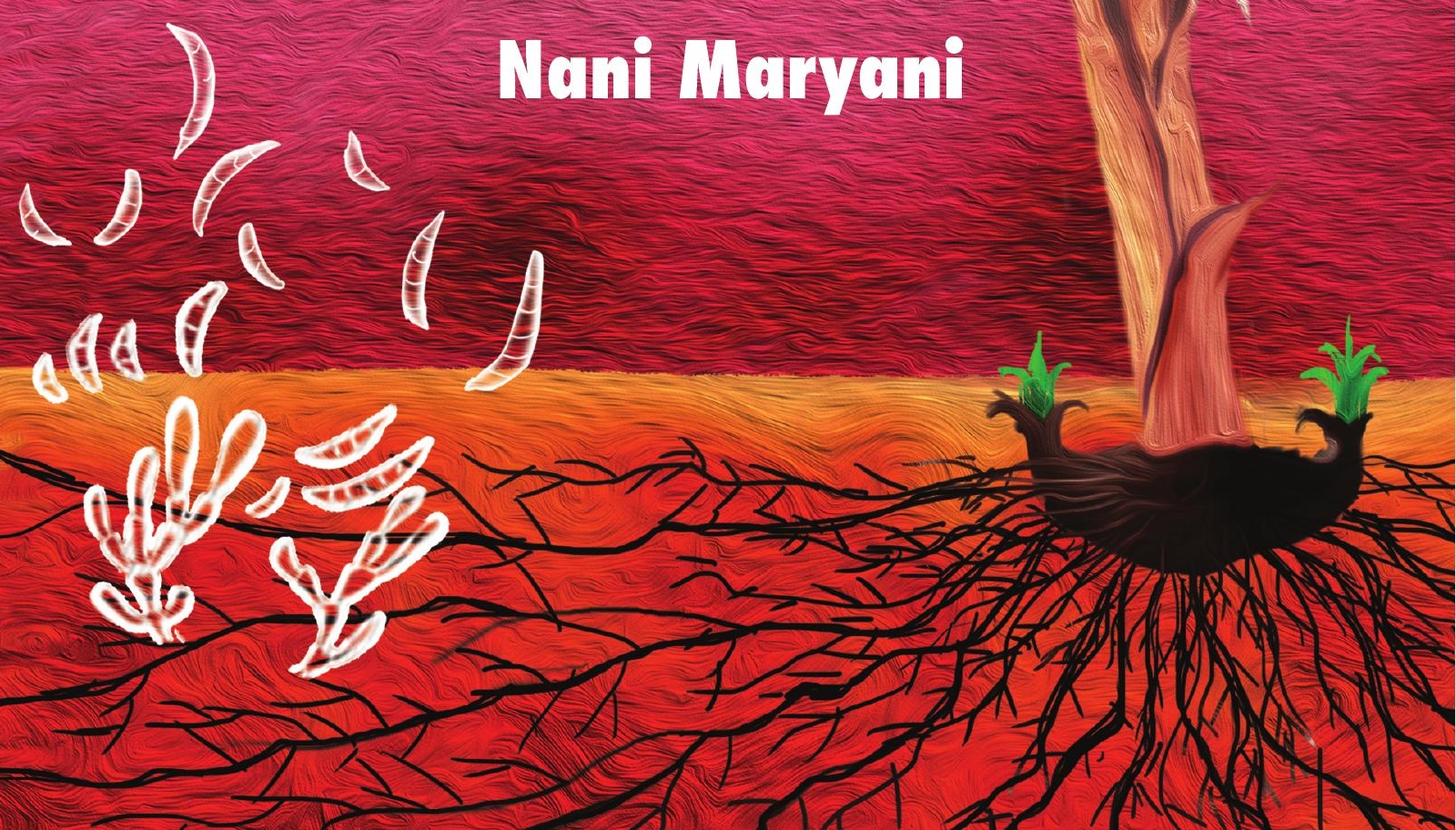


Propositions

1. The taxonomy of the Fusarium oxysporum species complex is outdated and requires a thorough revision.

(this thesis)

2. The future of banana research lies in genetics, which also requires the phenotyping of many isolates to understand the banana - Fusarium spp. interaction.

(this thesis)

3. Complexity guarantees durability and denounces monocultures as utter simplicity.

4. Collaboration in science diminishes skills.

5. Even the best politicians and scientists only flourish through logic, grammar and rhetoric.

6. Indonesian players excel in badminton because of their tactic and individuals skills to win the game.

Propositions belonging to the thesis, entitled

"A complex relationship: Banana \& Fusarium wilt in Indonesia"

Nani Maryani

Wageningen, 29 October 2018 



\section{A complex relationship \\ Banana \& Fusarium wilt in Indonesia}

Nani Maryani 


\section{Thesis committee}

\section{Promotors}

Prof.Dr Gerrit H.J. Kema

Special professor, Tropical Phytopathology

Wageningen University \& Research

Prof.Dr Pedro W. Crous

Special professor, Evolutionary Phytopathology

Wageningen University \& Research

\section{Other members}

Prof.Dr David M. Geiser, PennState University, Pennsylvania, USA

Prof.Dr Liesje Mommer, Wageningen University \& Research

Prof.Dr Martijn Rep, University of Amsterdam, NL

Prof.Dr Thomas W. Kuyper, Wageningen University \& Research

This research was conducted under the auspices of the Graduate School of Experimental

Plant Sciences 


\title{
A complex relationship Banana \& Fusarium wilt in Indonesia
}

\author{
Nani Maryani
}

Thesis

submitted in fulfilment of the requirements for the degree of doctor at Wageningen University by the authority of the Rector Magnificus,

Prof. Dr A.P.J. Mol, in the presence of the

Thesis Committee appointed by the Academic Board to be defended in public on Monday 29 October 2018 at 11 a.m. in the Aula. 


\section{Nani Maryani}

A complex relationship: Banana \& Fusarium wilt in Indonesia 210 pages

PhD thesis, Wageningen University, Wageningen, NL (2018)

With references, with summaries in English, Bahasa, and Dutch

ISBN: 978-94-6343-353-2

DOI: https://doi.org/10.18174/460210 
"Verily! In the creation of the heavens and the earth, and in the alternation of night and day, there are indeed signs for men of understanding"

Q. 3: 190

Untuk Mama dan Bapa 



\section{CONTENTS}

Acknowledgements

ix

Chapter 1. General introduction

Chapter 2. Phylogeny and genetic diversity of the banana Fusarium wilt pathogen Fusarium oxysporum f. sp. cubense in the Indonesian centre of origin

Chapter 3. Genotyping-by-sequencing reveals extensive genotypic diversity among sympatric Fusarium wilt pathogens of banana in Indonesia

Chapter 4. Pathogenic diversity of Indonesian Fusarium wilt pathogens in wild and cultivated bananas

Chapter 5. New endemic Fusarium species hitchhiking with pathogenic Fusarium strains causing Panama disease in small-holder banana plots in Indonesia

Chapter 6. General discussion

Summary

Ringkasan

Samenvatting

Curriculum vitae

List of publications

Education statement 



\section{Adknowledgements}

Alhamdulillâh. All praise and thanks are due to Allah.

A work of this size and duration cannot be completed through the sole effort of one person. The five PhD years in Wageningen comprise one of the most important phases in my life. The journey brought many good things in scientific growth, self-reflections and revival of faith. There are many to acknowledge, and as the saying of the Prophet Muhammad goes, "He who does not thank people does not thank God!"1

First and foremost, I must offer my heartfelt and sincere gratitude to my promotor and supervisor Prof. Gerrit H.J. Kema. Dear Gert, thank you for bringing me into the KNAW-SPIN program and my particular project to pursue my PhD research in your group. I am indebted for the hundreds of hours of discussion and supervision that you gave me. Your attention to every detail of the writing of the manuscripts is very valuable in shaping the whole story of the thesis. I will always miss our Friday afternoon discussions spanning science, culture, and tough topics on theology. Thank you for helping me discover the beauty of plant pathology in His magnificent creations of Fusarium and banana. From you, I learnt humbleness, patience, perfection, generosity and most importantly, consciousness of the grandeur of God's creation in scientific discovery. I shall forever be grateful for the trust that you placed in me. I hope I have lived up to your expectations.

I would also like to offer my sincere gratitude to my promotor Prof. Pedro W. Crous. Dear Pedro, thank you for the opportunity to work in your laboratory and for introducing me to the broad fungal community. I have very much enjoyed the research environment and overall friendliness of your group and others at the Westerdijk Institute. Thank you for your advices, encouragements and motivations. I will always miss working with you in your personal laboratory, energetically describing many new fungal species. Many dreams were built in my head even during the short period of my work in Utrecht. I hope the completion of this thesis will not be the end, but the starting point of flourishing Fusarium research in Indonesia. I am looking forward to continue collaborative work with both my promotors.

I would like to express my gratefulness to all co-authors for their help and contributions to the chapters of this thesis. Dear Lorenzo, thank you for your supervision, guidance, and trust in me. You are my mentor but also a friend in time of distress. I enjoyed working with you, our discussions on a wide range of topics from science to personal life. To Michael, thank you for sharing your knowledge and comments in shaping the DArT chapter. You taught me how to be very critical in every aspect of the manuscript. To Marcelo, you opened my horizon of Fusarium beyond oxysporum. Thank you for sharing your knowledge and kind help at any time. I enjoyed very much every discussion in the coffee time during my

\footnotetext{
1 Narated from Abu Hurayra, in the Kitab Sunan Abu Dawud, The Book of Manners: Regarding Giving Thanks in Return for a favor.
} 
short stay in Utrecht. To Paul, thank you for your patience in teaching me to understand my data from a statistician's perspective. I enjoyed our discussions and thank you for your high appreciation of Indonesia. To my external supervisor Dr. Anne Genissel, thank you for your advice and encouragements. I very much enjoyed our discussion during my visit to Grignon.

To the KNAW-SPIN team, the fellow-Indonesian banana project partners both in Indonesia and in The Netherlands. Dear Bu Yuyu, thank you for your guidance in choosing locations for my expeditions. Thank you for your commitment and company during our travels across Indonesia and sharing your knowledge on banana with me. I learnt different things and I never felt so grateful as Indonesian before and since that journey. To Bu Siti, thank you for your advices and motivations. To Bu Eka, Pak Rilus and Pak Arif, thank you for the joy and fun you brought in our team. To Hans, thank you for your encouragements. I appreciate your unexpected visit to the greenhouse, your questions and your endorsement on my participation in the European bioinformatics course in the beginning of this work. To Martijn, thank you for your friendliness and for adopting me in your group during the conferences that I attended. I appreciate your help for introducing me to the Foxy plant pathologist community and I enjoyed very much the company of your group. Many thanks for sharing your knowledge and wisdom from science to theology. To Sietze and Jetse, thank you for sharing your experience and knowledge. I enjoyed very much the fieldwork in Cianjur and Yogyakarta with you and all team members. It was a very valuable experience for me to work with a group of Dutch and Indonesian scientists in the field. I learnt many different things from each of the team members, not only from their expertise on different scientific disciplines but also got more insight in their personal characters.

Dear Mas Fajar, you are like my brother. I am grateful for your help at any circumstances. Thank you for sharing your knowledge and endless discussions on various topics while doing greenhouse experiments and at any time. May our friendship be preserved, Terima kasih! To Pak Iman, Mbak Heni and Mbak Nurmi, I am grateful for our friendship. I enjoyed very much our discussion in different places, sharing ideas to better Indonesia on various topics, and I hope we can continue this gathering in the future. I hope our work will be beneficial for our people.

Dear Sarah, I am grateful for our friendship. Many thanks for your company during my expedition in West Indonesia. You are my best traveller companion. I appreciate your help and understanding of the unexpected situations in the field. I enjoyed very much our conversations on various topics and the fun time, especially during our trip to Central Java. I hope, someday, we can enjoy Rorojongrang dance performances behind the shadow of the Prambanan temple at dawn. I wish you the best in your career and life.

I would also like to acknowledge agricultural offices, in each province who helped me with providing information, assistance and support during my expeditions. I thank Dinas Pertanian and BPPT provinsi Aceh, Sumatra Utara, Sumatra Barat, Sumatra Selatan, Lampung, Jawa Barat, Jawa Tengah, Jawa Timur, Kalimantan Timur, Kalimantan Barat, Kalimantan Selatan, Kalimantan Tengah, Sulawesi Selatan, Nusa Tenggara Timur and Papua. Too many to 
mention each of Dinas Kabupaten and the agricultural officers who helped me in collecting my samples. Your help was indispensable for which I am sincerely grateful.

I must also gratefully acknowledge the help and company of my fellow PhD students and colleagues in the Kema group. Dear Harold, thank you for your attention and for always being helpful. Your arrival in the group brought so much good. You are always ready for questions at any time. Dear Nadia, I am grateful for our friendship. I enjoyed our fun time while working in the laboratory, having lunch or coffee. I will always remember our DNA extraction song. I appreciate your care along these years. Dear Maricar, thank you for always making me laugh. Our Eastern backgrounds make me feel easy to talk and joke with you. Thank you for your support and smiles. Dear Fernando, thank you for your help and nice conversations. I enjoyed working with you and fun time in the green house especially during hectic times of inoculation. I wish you the best for your future career and life. Dear Lamia and Amir, I am grateful for our friendship. Thank you for always being available for questions and help. I enjoyed very much our conversations on various topics while working in the laboratory. Thank you for sharing your culture and traditions so that I learn and respect diversity and appreciate my own. To Cauca and Pablo, thank you for nice conversations. I wish you good luck in your careers and lives. To Einar, thank you for sharing your knowledge on Cuban banana. I wish you the best for your PhD. To the many BSc and MSc students who worked in our group during the last five years, thank you for joining me in various aspects of the experimental work. Truly appreciated.

To the Crous group members in Utrecht, I am grateful that I was part of the group. To Ewald, thank you for always being available to answer my questions especially when Lorenzo wasn't available. To Sandra, Joyce, Alejandra, Margarita, Tao, Lingwei and Vladi thanks for nice conversations during lunchtime, sharing your knowledge, practical things that I couldn't discover in the textbooks. I enjoyed every meeting and symposium that we attended, togetherness and jokes at our table. To Mieke, thanks for always providing me primers, trays and things that I need for laboratory work. To Arien, thanks for always taking care of me. To Maudi and Marijke, thanks for being nice office mates. To Manon, thank you for your kind help and warm welcome.

To Abdullah and Sara, thank you for always providing me a place to pray in your office. To Balazs, thank you for sharing your knowledge. To Anna, thanks for always being enthusiastic about my banana. To Michelle, thanks for always providing my sequences very fast.

I would like to thank all members of the Biointeractions and Plant Health business unit of the former Plant Research International, now Wageningen Plant Research, where I spent most of the time working on this thesis. I gratefully acknowledge all the technicians for their help inside and outside the laboratory work, their kind greeting and smiles. They were my first coaches when I started my laboratory work. To Odette, Marga and Els, thank you for sharing your knowledge and experiences. To Patricia, Helen, Carin and Mirjam, thank you for your kind help and assistance. To Trudy and Mark, thank you for nice conversations in the corridor. To Pieter, thank you for always being helpful at any time. To Marion, many thanks for your 
help and care from the first step I entered the university until the very last day to complete this thesis.

I would also like to acknowledge the Unifarm members for their help during my greenhouse experiments. To Bertus, Andre, Pauline and Eric, thank you for your help to prepare experiment tools. To Henk, thank you for taking care of my plants. To Casper, thank you for your warm greetings and nice stories about the people in West Java.

To all members of the Laboratory of Phytopathology, where this beautiful journey ends. To Bart, Francine and Jan, thank you for your kind greetings, smiles and encouragements. To my writing buddies Chara, Malaika, Aranka and Jinling, thank you for sharing bitter and sweet experiences, encourage one another to always be strong and be optimistic to finish our PhDs. To Jinbin, Hui, Martin, Nick, Xiaoqian, Nelia, Jasper, Edgar, Claudio, Xavier, Wen, Sander, Laura, Gabriel, Yaohua, Maikel, Laurens, Grardy and Ester, thank you for your smile and nice conversations in the fyto coffee corner. To Ali, many thanks for your help with administrative matters when I was about to reach the finish line.

I would like to thank all members of the Laboratory of Genetics, LIPI, Cibinong, Indonesia. To Teh Elin, thank you for being helpful in preparing tools and equipment for my sampling trips. To Mbak Tanti, Gita, Indah and Pak Dian, thanks for your help and nice conversations. I enjoyed my time at LIPI in planning my trips and preparing and processing my samples, and the knowledge that each one of you shared about different aspects of Indonesian bananas.

My teachers during my study at Bogor Agricultural University, IPB, for the knowledge and mannerism that they passed on me. To Dr. Gayuh Rahayu, thank you for inspiring me to continue to study mycology and plant pathology. To Prof. Lisdar Sudirman, thank you for your encouragements and motivation, especially when I was doing my MSc study in France. You inspired me to be passionate about my work, and to always think how to contribute to society.

I would like to thank Kelurahan PhD Indonesia as well as PPI Wageningen, former and present, for their companionship and brotherhood. To Pak Elham, Pak Taufik, Pak Waldi, Mbak Atin, Kang Dasep, Mbak Deni, Pak Dadan \& Teh Nia, Pak Dikky, Pak Eko, Mas Yuda, Uni Eli, Mbak Suparmi, Teh Pini, Mbak Shinta, Mbak Dian, Pak Ahmad, Bu Ita, Pak Ery, Teh Novi \& Mas Indra, Mbak Eka and Mbak Eva and many others that I couldn't mention one by one, thank you for being a big Indonesian family who support each other! To my neighbours at Bornsesteeg 7C9, Pak Fanny, Rusdi, Bang Komar, Kenardo, Roro, Mihris, Wang and Sanjay thank you for being nice to me. I enjoyed the food we shared with each other.

To my badminton buddies, the community where I found energy for mind and body. To Ko William \& Ci Sisi, thank you for making the group so solid and with high spirit in any competition we joined. I enjoyed every dinner and barbeque party that we had in your house. To Syukur, Mas Febri, Harum, Dea, Clement, Alim, Azril, Gumi \& Gendis and Ince, thanks for the beautiful games we had inside and outside De Bongerd. To my accidental coach, Lugas, thanks to your instructions I got two gold medals in the national and international student competitions. To Ko Sony, thanks for training my backhand shoot. To Arief, Fuad, Andre, Bang Yani, Hijjaz and Talitha, thanks for being always enthusiastic to play, even during exam weeks. 
To Daniel Lee, you are our best manager ever. I shall always miss Friday and Sunday afternoons with the joy and fun that you bring to the court.

To my akhawat, thank you for the beautiful ukhuwah and camaraderie over the course of my memory-filled nearly five years in Wageningen. To Mbak Vivi, you are like my sister. Thank you for always being a good listener to my stories, your sincere advices made me feel strong and to firmly stand on my ground. To Mbak Hikmah, thank you for your nice anecdotes on various topics. I enjoyed very much cycling with you to go to the mosque for tarawih at midnight and I never feel the sweetness of ibadah such as those nights of Ramadan. To Sister Anab, thank you for your kindness and hospitality. I enjoyed the time I spent in the mosque with all the activities, feeling grateful and humble for what I have back home in Indonesia. To Mbak Atik and Mbak Aviv, thank you for sharing your knowledge and experience which always inspired me. I will always miss your delicious cakes and dishes. I enjoyed the time we cooked and laughed together on your smart jokes. To Moskee Wageningen community and PPI Pengajian Wageningen, I pray that all the goodness that you spread will add weight to our scale. I hope that someday I can pray in our new Moskee, to see the fruit of our efforts and works to have our own masjid.

I would like to thank the academic board of Universitas Sultan Ageng Tirtayasa Banten for giving me the opportunity and supporting me to do my PhD at Wageningen University. To my colleagues in Biology UNTIRTA, thank you for your support and encouragements to finish my PhD.

Last and most importantly, to my beloved family, my sisters, Ratih and Yulia, thank you for your support, patience and love. I will always be in debt to both of you for being with our parents, as I was not always able to be with them and serve them during times of need. To my two little Muhammad, Hafidz and Rasyid, and my little river Salsabila, you shall always be the coolness of our eyes. To Mama and Bapa, thank you for raising me, you sacrificed everything to give me the best education, you encouraged and supported me for every endeavour in which I partook. All of this is possible because of your continuous dua, day and night. It is to them I dedicate this thesis.

Untuk keluargaku tersayang, adik-adikku, Ratih dan Yulia, terima kasih untuk semua dukungan, kesabaran dan kasih sayang. Aku akan selalu mengingat kebaikan kalian untuk selalu menjaga orang tua kita, karena aku tidak selalu ada di rumah untuk melayani mereka. Untuk dua Muhammad kecilku, Hafidz dan Rasyid, sungai kecilku Salsabila, kalian akan selalu menjadi penyejuk mata kami. Untuk Mama dan Bapa, terima kasih telah membesarkanku, mengorbankan segalanya untuk pendidikanku, memberikan semangat dan mendukungku dalam segala hal yang kulakukan. Keberhasilanku adalah berkat doa kalian siang dan malam. Untuk kalian kupersembahkan karya ini. 

Chapter 1

General introduction 
The global human population increases exponentially. However, agricultural progress lags behind and hence, food security for the predicted 9.8 billion people by 2050 is a main concern (Population Reference Bureau, www.prb.org). Thomas Robert Malthus already predicted in his essay On the Principle of Population (1798), that a catastrophic food scarcity will become apparent as human populations grow geometrically (i.e. doubling with each cycle) while food production grows at an arithmetic rate (i.e. by the repeated addition of a uniform increment). He, however, overlooked the impact of advanced technology in agriculture and considered subsistence farming as the only source of food production. Through plant breeding, fertilizers, irrigation and mechanization - to name a few - food supply can outpace population growth. Nevertheless, the Malthusian view is not passed, as contemporary agriculture faces many challenges, not the least by new and expanding plant diseases (Bebber et al. 2014).

Plant diseases have dramatic impacts and destabilizing effects on societies. They can change the course of history, due to social-economic and political upheaval. One of the most destructive plant disease epidemics ever recorded in human history is Fusarium wilt of banana, also known as Panama disease (Simmonds 1962, Stover 1962). The impact of Fusarium wilt on food security, as banana is an important part of local diets, is not well documented. The disease has caused huge economic losses and has had a massive social impact due to unemployment in many banana exporter countries in Latin America (Koeppel 2009). The disease devastated one of the most important fruits and staple food crops which is grown in more than 135 countries in the (sub)tropics (FAO 2018, http://www.fao.org/). In 2016, the global banana production reached 78.8 million tonnes, with 18.6 million tonnes accounting for exports, mainly from Central and South America (representing $30 \%$ of the global productions) (Fruit Trop 2017).

Currently, the threat of Fusarium wilt to banana is recurring, thereby alerting producers but also importers and particularly consumers, as they may see their beloved fruit go extinct. However, in the centre of origin of banana, which from the co-evolutionary standpoint is also the centre of origin of major pathogens threatening the crop (Ploetz \& Pegg 1997), hundreds of excelling varieties are grown. This thesis discovers and describes the diversity of the Fusarium wilt pathogen of banana in its centre of origin, Indonesia.

\section{Bananas: history and early domestication}

Nowadays, banana is one of the most popular fruits in the world. People consume more than 100 billion bananas each year, whether as staple food or fruit, which make its one of the largest crops produced after wheat, rice, and corn (FAO 2018, http://www.fao.org/). Banana is one of the earliest plants to be cultivated by humans, which started approximately, 7000 BC in South-East Asia and Papua New Guinea, marking the early history of tropical agriculture (De Langhe \& De Maret 1999). Bananas were most likely introduced to Africa via 
Madagascar in the ancient time by Indonesian immigrants (Vérin 1981). However, the dispersal of bananas was mainly by Arab traders in the first millennia to Mesopotamia, Palestine, and Egypt, and became popular in that area as it is mentioned in the Koran as the "fruit of paradise" (Kervegant 1935, Koeppel 2007). The linguistic evidence supports this notion, that the first scientific term given to banana is Musa paradisiaca Linn (Linnaeus 1753) that means "fruit from paradise" (Musa, mauz-Arabic = fruit; paradisiaca, firdaws-Arabic = paradise) (Koeppel 2007). It took until the 15th century for Portuguese traders to introduce bananas to the New World, i.e. South America and Caribbean islands, which in the present day supplies most of the commercially produced bananas to the western world, i.e Europe and North America (Stover \& Simmonds 1987).

Bananas are herbaceous monocotyledon perennial plants belonging to the family of Musaceae that includes the genera Musa and Ensete. The section Eumusa in the genus Musa includes wild and edible bananas that we eat today (Simmonds \& Shepherd 1955). Generally, wild bananas are seeded, less pulpous and found wild in the forest or in abandoned areas, whereas edible bananas are seedless, pulpy fruits and grown in home gardens or plantations (Fig. 1). Musa acuminata Colla $(2 n=22, A A)$ and Musa balbisiana Colla $(2 n=22, B B)$ are the ancestors of all edible bananas. Both wild banana species originate from the Indo-Malayan region, with $M$. acuminata being the most diverse sub-species found in South-East Asia, and M. balbisiana occurring in the Indian subcontinent and also in South-East Asia (Valmayor et al. 1999, Perrier et al. 2011; Fig. 1F). Both wild species hybridized and diversified into various cultivated varieties (cultivars) whose genomic composition and ploidy level were derived from these two wild diploid parents. The edible cultivars can be found as diploid $A A$ and $A B$ groups, triploid $A A A, A A B, A B B$, and $B B B$ groups, and occasionally tetraploid, $A A A A, A A A B$, and $A B B B$ groups. The terms plantain, cooking banana and banana have been used interchangeably, but academically "plantain" has been used to refer to the starchy banana AAB group that is eaten after cooking, "cooking banana" has been used to refer to the starchy banana ABB group, and "dessert banana" has been used to refer to the sweet banana, that is eaten fresh upon ripening (Valmayor et al. 1999). However, in the place where bananas are indigenous, "banana" refers to any type of the above-mentioned terms. The term "Pisang", which means "banana" in Bahasa and Indo-Malayan language, followed by local names is used to describe cultivated varieties in the Indo-Malayan region, especially in Indonesia. 

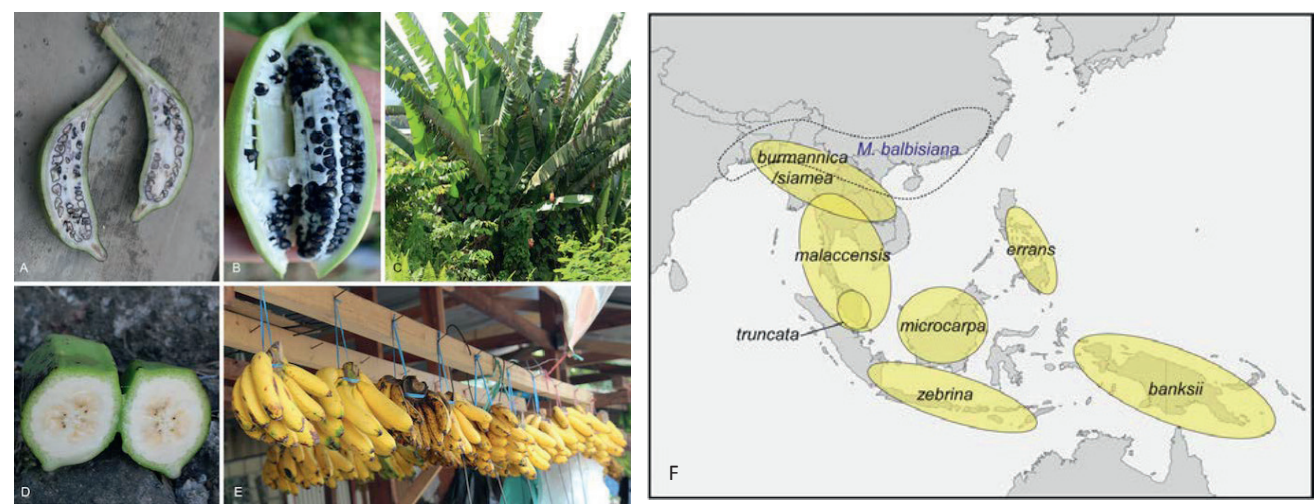

Fig. 1. A. Seeded wild banana species Musa acuminata var. microcarpa. B. Musa acuminata var. alasensis (Photo by F. Ahmad). C. Musa bornensis growing as wild massive herbs in the indigenous tropical forest of Kalimantan, Indonesia. D. Seedless cultivated banana, Pisang Kepok. E. Local banana cultivars for sale in a traditional open market stand. F. Geographical distribution of Musa balbisiana and subspecies of Musa acuminata, the wild ancestors of cultivated bananas (Perrier et al. 2011).

Indonesia is the homeland of bananas. They play a central role in the Indonesian culture and heritage (Kennedy 2009). Hundreds of local varieties are grown across the Indonesian archipelago, making it the number one fruit commodity in the country (http://pusdatin.setjen.pertanian.go.id). Indonesia is the primary gene centre for banana, the contact area between species and subspecies of wild Musa (Simmonds 1962, Perrier et al. 2011; Fig. 1F) and hosts around 71 Musa species, of which 15 are sub-species of $M$. acuminata (Nasution 1990; Fig. 2). The origin of M. balbisiana is largely outside Indonesia, primarily the Indian sub-continent, South China and The Philippines. Yet, the diversity of this wild species is high in Indonesia especially on the islands of Java, Sumatra, and Sulawesi (De Langhe et al. 2009, Ochse \& van den Brink 1931, Ahmad 2013). The diversity of wild Musa species in Indonesia results in a huge diversity of approximately 200 cultivated varieties which are largely well identified and maintained in the Purwodadi Botanical Garden (Kebun Raya Purwodadi) in East Java (166 cultivars, mainly from Eastern Indonesia; Hapsari et al. 2015), the Research Center for Biology (Pusat Penelitian Biologi LIPI Cibinong) in West Java (191 cultivars, including 42 wild Musa accessions; Poerba et al. 2016) and the Indonesian Tropical Fruit Research Institute (BALITBU Solok) in South Sumatra (300 cultivars; Sutanto 2018, pers. comm.). In 2006, the International Network for the Improvement of Banana and Plantain (INIBAP, current name Biodiversity International) estimated that, 1000 banana cultivars occurred in tropical and subtropical regions. Based on a rough estimate, Indonesia hosts around $50 \%$ of the total global banana diversity. It is essential to conserve banana germplasm for research and development and, most importantly, it provides an excellent source of diversity for the various banana breeding programs. 


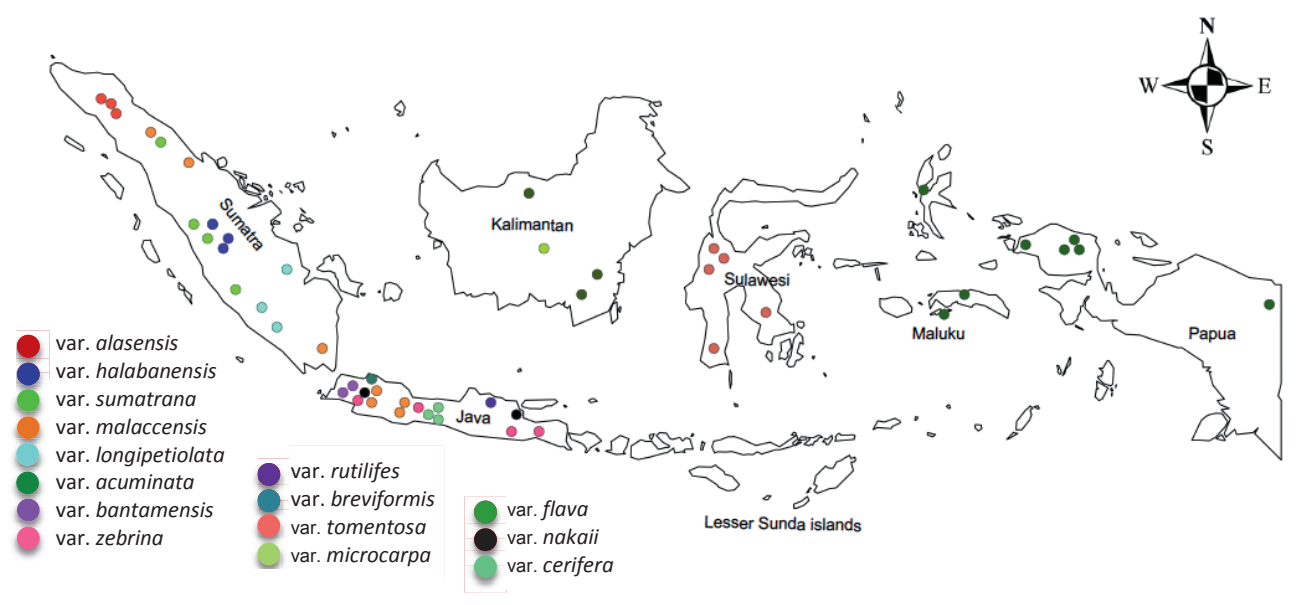

Fig. 2. Geographical distribution of 15 sub-species of the wild seeded banana, Musa acuminata (adopted from Nasution 1990).

\section{Banana production}

In contrast to the common knowledge that banana is an export crop, $70 \%$ of the global banana production is aimed for domestic markets, and only $30 \%$ for export or trade (FAO 2015). Thus, the majority of bananas is produced from smallholder farms, and is staple food in many countries in Africa, tropical America, and Asia (Ploetz et al. 2015). Indonesia is among the top 10 banana producers of the world and mainly supplies the domestic market (90\%) with only a small amount for export (10\%), primarily to China (53.74\%), Saudi Arabia (25.68 \%), Kuwait (15.51 \%) and Malaysia (3.66 \%) (http://pusdatin.setjen.pertanian.go.id/). In Indonesia, and many other Asian countries banana is grown in backyards, in a mixed cropping system as well as in commercial smallholder production and corporate farms or agri-business plantations (Fig. 3). It is a cash crop that costs almost nothing, but provides a substantial income to over five million households. In 2016, >7M tons of bananas were produced from 81 812 ha, which contributes to $38 \%$ of the national fruit production (Central Bureau Statistics, Directorate of Horticulture 2016, http://www.pertanian.go.id). The fruits are abundant in any traditional market as well as in modern supermarkets, and are highly appreciated across society as the national snack fruit and ingredient in many sweet dishes. Therefore, bananas are planted everywhere near people's livelihoods such as in yards, fields, on hills, mountains, and along rivers (Fig. 3). 


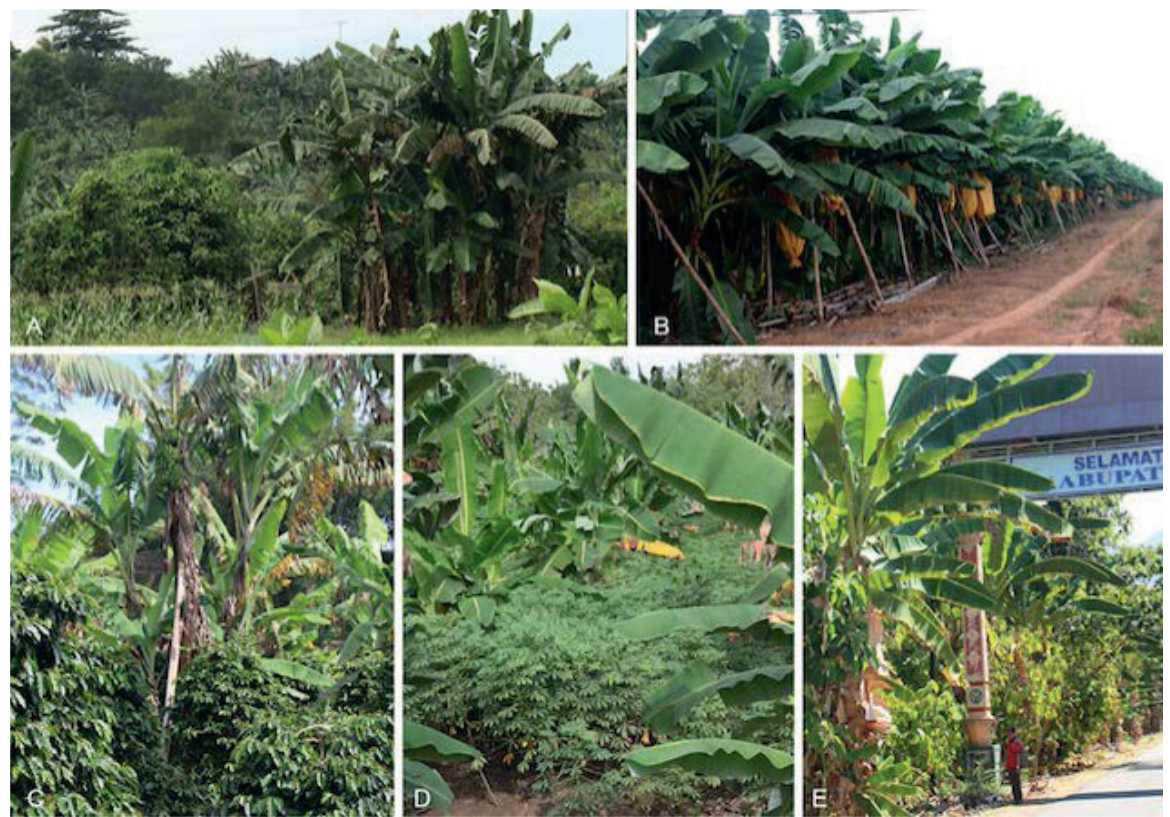

Fig. 3. Types of banana cultivation in Indonesia. A. Backyard plantation, East Kalimantan. B. Monoculture commercial plantation, Lampung, South Sumatra. C. Intercropping in a coffee plantation, Brastagi, North Sumatra. D. Mixed cropping with cassava, Central Java. E. Bananas grow as weeds by the roadside, Maumere, Flores.

\section{Fusarium wilt of banana}

Despite its great importance, global banana cultivation faces significant problems due to diseases. Fusarium wilt or Panama disease is one of the most devastating plant diseases ever recorded in the history of an agricultural crop. In the beginning of the 1960's, around 40,000 ha of Gros Michel plantations were abandoned in Latin America because of this disease. Initially, the cause of the disease was a big mystery, until Smith (1910) isolated a purple fungal culture which produced both macro- and microconidia, and demonstrated that the fungus was the cause of a Cuban banana plant disease, to which he assigned the name Fusarium cubense. Brandes (1919) for the first time provided a formal description of the fungus, conducted pathogenicity tests and concluded that the fungus was host-specific. In later studies, Waite \& Stover (1960) determined that the Gros Michel (AAA) and Silk (AAA) varieties were susceptible to Race 1 , and that the Bluggoe (ABB) variety was susceptible to Race 2. In 1940, Snyder \& Hansen proposed the name Fusarium oxysporum Schlecht f. sp. cubense (Foc) for this pathogen, which then was widely adopted by most plant pathologists. However, "Panama disease" became notorious after the first big epidemic in Panama, and Stover (1962) used this name for the first time in Jamaica. Later on, the name "Fusarium wilt disease" was preferred and widely used in agreement with other crop diseases caused by Fusarium oxysporum. 
Even though the first identification of the disease was in Latin America, the pathogen was thought to come from the host origin in the Indo-Malayan region (Stover 1962). In general, pathogens evolve with the hosts since the start of agriculture, during domestication and selection for cultivation by humans (Stukenbrock \& McDonald 2008). Thus, there is no doubt that Indonesia, as the centre of origin and diversity of banana also hosted its pathogens. The first recognition of Fusarium wilt of bananas in Indonesia was in 1916, in a banana plantation on the island of Java (Rijks 1915, in Stover 1962). At that time, there was a massive migration of people from Java to Suriname, which could account for the international dissemination of the disease (Malefijt 1963). Gros Michel affected by Fusarium wilt was recognised very early in Suriname (1904), where it was likely intercropped with cocoa, as many of the immigrant workers from Java worked in cocoa plantations (Stover 1962). Such records trace back the origin of the pathogen that likely disseminated along with its host from SouthEast Asia. This hypothesis was later substantiated by O'Donnell et al. (1998) who suggested that South-East Asia is the place of co-evolution between the Fusarium wilt pathogen and banana.

The banana industry in Latin America was saved by the introduction of the resistant Cavendish variety. However, two decades later, a new strain called Race 4 was identified in Cavendish plantations in Taiwan (Su et al. 1986). This new strain was virulent to many banana varieties in tropical areas, and was later called Tropical Race 4 (TR4) (Gerlach et al. 2000, Ploetz 2006). The dissemination of TR4 around the globe is recurring to many banana producing countries, for both export as well as for staple food products. To date the TR4 epidemic spans three continents (Asia, Australia, and Africa), affecting of a total of 15 countries (http//: www.fusariumwilt.org; Fig. 4) and it seems a repetition of history once this pathogen disseminates to the American continent.

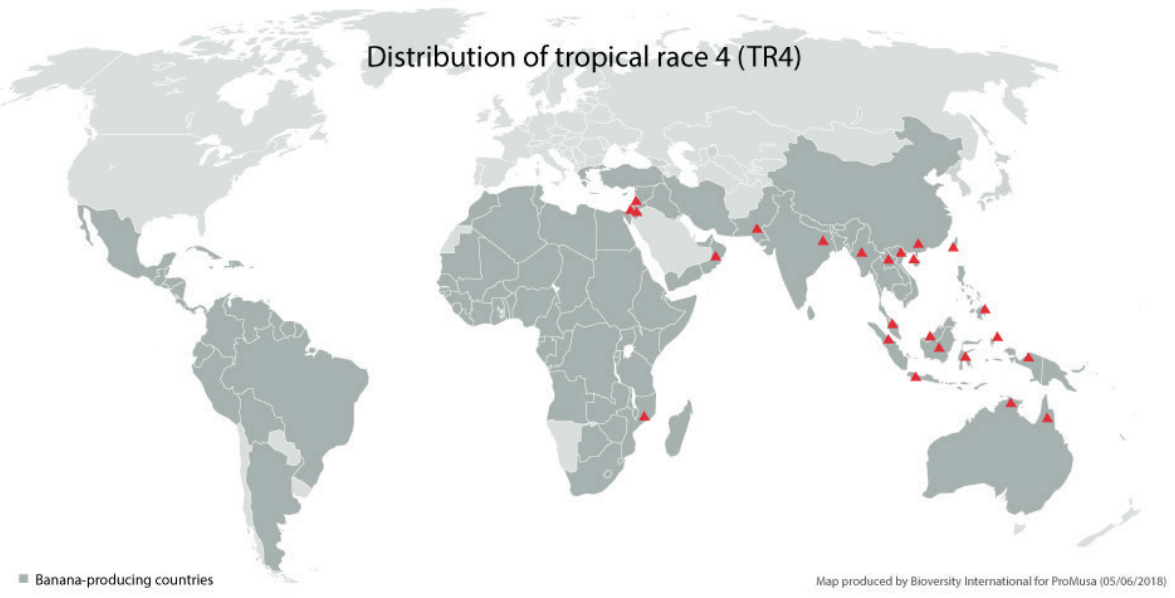

Fig. 4. Global dissemination of Tropical Race 4 (TR4). 
In Indonesia, Fusarium wilt is recognized by local people as "penyakit layu" with major symptoms of wilting and yellowing of the leaves, collapsing of leaf petioles, and systemic infection causing longitudinal splitting of the lower portion of the pseudostem (Fig. 5). The clearest symptom to distinguish the disease from wilting caused by other biotic or abiotic agents is the discoloration of the pseudostem and corm (Moore et al. 1995; Fig. 5). The disease already spread from the Western part (Sumatra) to the Eastern part (Papua) of Indonesia (Nasir et al. 1999) and TR4 has devastated thousands of hectares of Cavendish plantations in South and North Sumatra (Jumjunidang et al. 2012). Moreover, many local popular varieties succumbed to the disease (Hermanto et al. 2009).

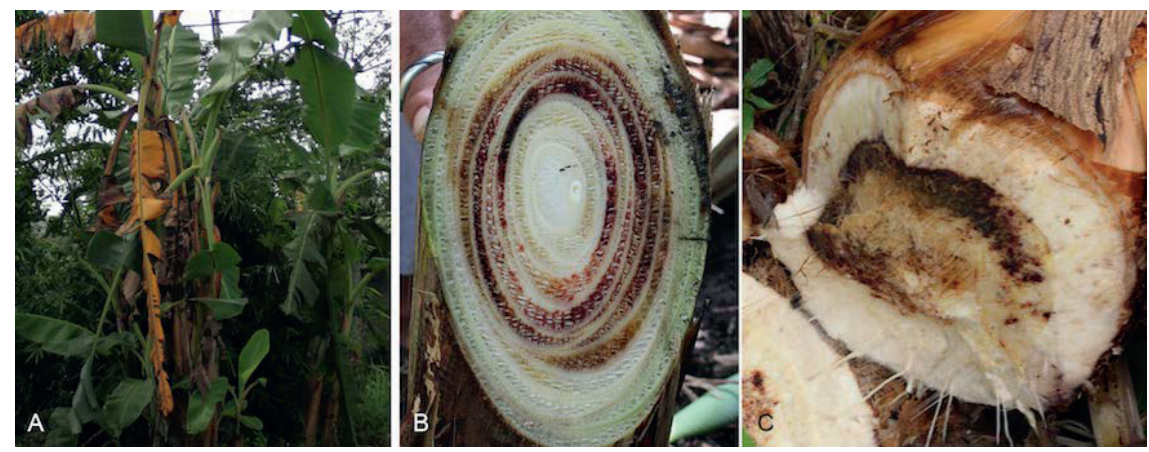

Fig. 5. Symptoms of Fusarium wilt of bananas. A. Wilting and yellowing of the leaves. B. Discoloration of the pseudostem. C. Discoloration of the corm.

To date, there is no effective control to manage the epidemic due to the persistence of chlamydospores that can survive in contaminated soils for decades. The above-mentioned impact of the disease on a global and local scale affects food security in many countries. Finding a resistant variety is the best solution to stop the epidemic as demonstrated by the resistant Cavendish that quenched the previous epidemic which was caused by Race 1 strains. Despite the fact that Cavendish has maintained its resistance against Race 1 for more than 50 years in areas prone to Fusarium wilt, neither the genetics of resistance nor the genes responsible for pathogenicity were explored and understood. Therefore, striving for resistance to Fusarium wilt requires elucidation of resistance as well as deciphering the interaction between Foc and banana. The race concept in Foc is only based on a limited set of varieties which consequently overshadows details of diversity in Foc populations (Cunha et al. 2015, Karangwa et al. 2017). Hence, the resistance of the host and pathogenicity of the pathogen are overly simplified. However, to unveil the interaction of the host and pathogen, both the degree of resistance and pathogenicity are very important keys to clarify the type of interaction that occurs in this particular pathosystem. It is of foremost importance to scrutinize resistance to Fusarium wilt in banana (D'Hont et al. 2012, Dale et al. 2017, Zuo et al. 2018). The identification of resistance to TR4 in Musa acuminata var. malaccensis is an 
obvious example of a resource in a wild variety from the centre origin of bananas. Moreover, many cultivated varieties are also sources of resistance (Handayani et al. 2017). Thus, the diversity of both wild and cultivated varieties needs to be explored in the quest for resistance to Foc. In this thesis, we explored diversity in Fusarium spp. affecting banana and studied the interaction with some banana varieties of Indonesian origin. Therefore it provides a basis for improving the understanding of the banana-Foc pathosystem.

\section{Fusarium oxysporum f. sp. cubense: taxonomy, diversity and co-evolution}

Fusarium oxysporum is an ascomycete fungus that is commonly found as a soil inhabitant worldwide. Fusarium oxysporum f. sp. cubense (Foc), together with many other pathogenic isolates from a wide range of important crops, is part of the Fusarium oxysporum species complex (FOSC) (Baayen et al. 2000, O'Donnell et al. 2004). Due to the lack of a sexual life cycle, the taxonomy of FOSC was traditionally defined by morphological characters, and delimited by asexual structures (Wollenweber \& Renking 1935, Booth 1971, Nelson et al. 1983). With a more pragmatic and broad definition, especially for plant pathologists, Snyder \& Hansen (1940) subdivided this complex by introducing formae speciales (ff. spp), thus strains infect particular plant hosts but are not pathogenic to others. Formae speciales are further sub-divided into races, which refer to host cultivar specificity (Armstrong \& Armstrong 1981). However, molecular phylogeny showed that many formae speciales are polyphyletic (Baayen et al. 2000). Therefore, formae speciales and races are considered as physiological classifications, without taxonomic significance, but facilitate communication among plant pathologists (Gordon 2017). As molecular data are continually accumulated, many members of the FOSC are subject to taxonomical revisions and Foc is no exception.

The phylogeny and diversity of Foc have been studied using various morphological, physiological and molecular genetic tools (O'Donnell et al. 1998, Groenewald et al. 2006, Fourie et al. 2009, Ordonez et al. 2015, Mostert et al. 2017). While all results suggest coevolution of Foc and banana in South East Asia, little is known about the diversity of the pathogen in the centre of origin of the host, which is likely to represent its full diversity. In this thesis, we explore, exploit and analyse the diversity of Foc from natural ecosystems in Indonesia where hundreds of local banana varieties are grown. This knowledge is of great importance for sustaining global banana production through advanced breeding programs.

\section{Outline of the thesis}

The first chapter lays out the history and current knowledge of the diversity of banana and the fungal pathogen Fusarium oxysporum f. sp. cubense (Foc), the situation of Fusarium wilt in Indonesia and at the global perspective of the disease. It culminates in the importance and urgency of a diversity study of Foc in the centre of origin of banana in Indonesia. 
The second chapter is the first of four experimental chapters and describes the exploration of Fusarium wilt of bananas across six main islands of Indonesia: Java, Flores, Kalimantan, Papua, Sumatra and Sulawesi (details of geographical locations, ecology, and host identity were recorded). More than 200 Fusarium isolates from many local varieties were isolated and Multi Locus Sequence Typing (MLST) was used for molecular identification and characterization. Multi-gene phylogenetic analyses were used for identification of new Fusarium spp. to replace Foc lineages in the FOSC. New species names were assigned and formal taxonomic descriptions were given. Furthermore, pathogenicity tests were conducted to further characterize new phylogenetic species.

The third chapter describes a population study using genotyping-by-sequencing (Diversity Array Technology [DArTseq]) as a technique for diversity analyses of the Indonesian isolates comprising Fusarium species identified in chapter 2. Polymorphic DArTseq markers were used for hierarchical clustering and genotype identification in each Fusarium species. Association between species, genotype, and physiological race were also analysed. The advantage of DArTseq and its robustness to assess genotypic diversity in the Fusarium spp. causing wilt in banana are discussed.

The fourth chapter provides an insight into the pathology of the Fusarium spp. banana pathosystem. The knowledge on the diverse genotypes of Indonesian isolates in chapter $\mathbf{3}$ was used to challenge wild and cultivated banana varieties with Fusarium diversity. Phenotyping assays were conducted in well-controlled greenhouse experiments that took almost two consecutive years to collect qualitative and quantitative disease data.

The fifth chapter describes the discovery of other Fusarium species which were isolated from Fusarium wilt diseased samples discussed in chapter 2. Twenty isolates were identified as members of three other Fusarium species complexes, namely the Fusarium fujikuroi species complex (FFSC), the Fusarium incarnatum-equiseti species complex (FIESC) and the Fusarium sambucinum species complex (FSSC). Multi-gene phylogenetic analyses of each complex were used for phylogenetic species recognition. In addition, pathogenicity tests were conducted to check host specificity of these species. The last chapter provides a general discussion of the thesis. The primary findings are discussed in a broader context of banana production and additional and required future research is suggested.

\section{References}

Armstrong GM, Armstrong JK (1981). Formae speciales and races of Fusarium oxysporum causing wilt diseases. In: Fusarium: Diseases, Biology and taxonomy (Nelson PE, Toussoun TA, Cook RJ, eds). The Pennsylvania State University Press, USA: 391-399.

Ahmad F (2013). Keragaman Genetik Pisang Musa balbisiana Colla di Indonesia menggunakan penanda Amplified Frangment Length Polymorphism (AFLP). Master thesis, Sekolah Pasca Sarjana, Institut Pertanian Bogor (IPB), Indonesia.

Baayen RP, O'Donnell K, Bonants PJM, et al. (2000). Gene genealogies and AFLP analyses in the Fusarium oxysporum complex identify monophyletic and nonmonophyletic formae speciales causing wilt and rot disease. Phytopathology 90(8): 891-900. 
Bebber DP, Holmes T, Gurr SJ (2014). The global spread of crop pests and pathogens. Global Ecology and Biogeography 23: 1398-1407.

Beckman CH (1987). The Nature of Wilt Diseases in Plants. The American Phytopathological Society, Minnesota USA.

Booth C (1971). The genus Fusarium. CAB, Commonwealth Mycological Institute, UK.

Brandes EW (1919). Banana wilt. Phytopathology 9(9): 339-390.

Cunha CMS, Hinz RH, Pereira A, et al. (2015). Aggressiveness and genetic diversity of Fusarium oxysporum f. sp. cubense from Santa Catarina, southern Brazil. Tropical Plant Pathology 40(5): 326-334.

Dale J, James A, Paul JY, et al. (2017). Transgenic Cavendish bananas with resistance to Fusarium wilt tropical race 4. Nature communications $\mathbf{8}(1)$ : 1496

De Langhe E, De Maret P (1999). Tracking the banana: its significance in early agriculture. In Prehistory of food: Appetites for change (One world archeology) (Gosden C, Hather J, eds) Oxford press, UK: 377-396.

De Langhe $E$, Vrydaghs L, De Maret $P$, et al. (2009). Why bananas matter: an introductory to the history of banana domestication. Ethnobotany Research \& Applications 7: 165-177.

D'Hont A, Denoeud F, Aury JM, et al. (2012). The banana (Musa acuminata) genome and the evolution of monocotyledonous plants. Nature 488(7410): 213-217.

FAOSTAT (2018) http://www.fao.org/faostat/.

Fourie G, Steenkamp ET, Gordon TR, et al. (2009). Evolutionary relationships among the Fusarium oxysporum $\mathrm{f}$. sp. cubense vegetative compatibility groups. Applied and Environmental Microbiology 75(14): 4770-4781.

FruitTrop magazine (2017). Banana and avocado close-ups. Banana statistqiues, April edition: 86-87. CIRAD Agricultural for development, Montpellier, France.

Gerlach KS, Bentley S, Moore NY, et al. (2000). Characterisation of Australian isolates of Fusarium oxysporum $\mathrm{f}$. sp. cubense by DNA fingerprinting analysis. Australian Journal of Agricultural Research 51(8): 945-953.

Gordon TR (2017). Fusarium oxysporum and the Fusarium wilt syndrome. Annual Review of Phytopathology 55(1): 23-9.

Groenewald S, Van Den Berg N, Marasas WFO, et al. (2006). The application of high-throughput AFLP's in assessing genetic diversity in Fusarium oxysporum f. sp. cubense. Mycological Research 110(3): $297-305$.

Handayani T, Martanti D, Poerba YS, et al. (2017). Deteksi awal ketahanan beberapa aksesi pisang lokal dan hasil persilangan terhadap penyakit layu Fusarium (Foc VCG 01213/16 TR4). Journal Hortikultura Indonesia 8(2): 88-96.

Hapsari L, Lestari DA, Masrum A (2015). Album Koleksi Kebun Raya Purwodadi Seri-1: 2010-2015. Unit Pelaksana Teknis Konservasi Tumbuhan Kebun Raya Purwodadi-LIPI press, Surabaya, Indonesia.

Hermanto C, Sutanto A, Jumjunidang, et al. (2009). Incidence and distribution of Fusarium wilt disease of banana in Indonesia. International ISHS-ProMusa Symposium on Global Perspectives on Asian Challenges 897: 313-322.

INIBAP (2006). INIBAP annual report: Global Conservation Strategy for prepared by INIBAP with the collaboration development community. Montpellier, France.

Jumjunidang, Edison, Riska et al. (2012). Penyakit layu Fusarium pada tanaman pisang di provinsi NAD: Sebaran dan identifikasi isolat berdasarkan analisis vegetative compatibility group. Jurnal Hortikultur 22(2): 164171.

Kennedy J (2009). Bananas and People in the Homeland of Genus Musa: Not just pretty fruit. Ethnobotany Research \& Applications 7: 179-197.

Karangwa P, Mostert D, Ndayihanzamaso P, et al. (2017). Genetic Diversity of Fusarium oxysporum f. sp. cubense in East and Central Africa. Plant Disease 102(3): 552-560.

Kervégant D (1935). Le bananier et son exploitation. Paris société d'éditions, gèographiques, maritimes et colonials, France.

Koeppel D (2007). Banana: The fate of the fruit that changed the world. Hudson Street Press, New York, USA.

Malefijt ADW (1963). The Javanese of Surinam: segment of a plural society. Van Gorcum \& Comp. N.V., Assen, The Netherlands.

Malthus RT (1798). An essay on the principle of population. Printed for J. Johnson, in St. Paul's Church-Yard, London, UK.

Mostert D, Molina A, Daniells J, et al. (2017). The distribution and host range of the banana Fusarium wilt fungus, Fusarium oxysporum f. sp. cubense, in Asia. PLOS ONE 12(7): e0181630.

Nasir N, Pittaway PA, Pegg KG, et al. (1999). A pilot study investigating the complexity of Fusarium wilt of bananas in West Sumatra, Indonesia. Australian Journal of Agricultural Research 50(7): 1279-1283.

Nasution RE (1990). A Taxonomic Study of the Species Musa acuminata Colla with its intraspesific taxa in Indonesia. Ph.D dissertation: Tokyo University of Agriculture, Japan. 
Nelson PE, Marasas WFO, Toussoun TA (1983). Fusarium Species: An Illustrated Manual for identification. The Pennsylvania State University press, Pennsylvania, USA.

Ochse JJ, Bakhuizen van den Brink RC (1931). Vegetables of the Dutch East Indies : edible tubers, bulbs, rhizomes and spices included : survey of the indigenous and foreign plants serving as pot-herbs and side-dishes. Nijhoff, The Hague, NL.

O'Donnell K, Kistler CH, Cilgenik E, et al. (1998). Multiple evolutionary origins of the fungus causing Panama disease of banana: Concordant evidence from nuclear and mitochondrial gene genealogies. Proceedings of the National Academy of Sciences of the USA 95(5): 2044-2049.

O'Donnell K, Sutton DA, Rinaldi MG, et al. (2004). Genetic diversity of human pathogenic members of the Fusarium oxysporum complex inferred from multilocus DNA sequence data and amplified fragment length polymorphism analyses: evidence for the recent dispersion of a geographically widespread clonal lineage and nosocomial origin. Journal of Clinical Microbiology 42(11): 5109-5120.

Ordonez N, Seidl MF, Waalwijk C, et al. (2015). Worse comes to worst: bananas and Panama disease-when plant and pathogen clones meet. PLoS Pathogen 11(11): e1005197.

Perrier X, De Langhe E, Donohue M, et al. (2011). Multidisciplinary perspectives on banana (Musa spp.) domestication. Proceedings of the National Academy of Sciences of the USA 108(28): 11311-11318.

Ploetz R, Pegg K (1997). Fusarium wilt of banana and Wallace's line: Was the disease originally restricted to his Indo-Malayan region? Australasian Plant Pathology 26(4): 239-249.

Ploetz RC (2006). Panama disease, an old nemesis rears its ugly head: part 2, the cavendish era and beyond. Plant Health Progress March: 1-17.

Ploetz RC, Kema GHJ, Ma LJ (2015). Impact of diseases on export and smallholder production of banana. Annual Review of Phytopathology 53: 269-288.

Poerba YS, Witjaksono, Martanti D, et al. (2016). Katalog Pisang, Koleksi Kebun Plasma Nutfah Pisang Pusat Penelitian Biologi Lembaga IImu Pengetahuan Indonesia. LIPI Press, Jakarta, Indonesia.

Rijks AB (1915). Rapport over een Onderzoek naar de Pisangsterfte op de Saleirereinlanden. Dep. Landb. Nijverheit en Handel (Dutch East Indies). Meded. Lab. Plantenziekten 21. in full Mededeelingen van het Laboratorium voor Plantenziekten.

Simmonds N, Shepherd K (1955). The taxonomy and origins of the cultivated bananas. Journal of the Linnean Society of London, Botany 55: 302-312.

Simmonds N (1962). The Evolution of Bananas. London: Longman Itd.

Smith E (1910). A cuban banana disease. Science 31(802): 754-757.

Snyder WC, Hansen HN (1940). The species concept in Fusarium. American Journal of Botany 27(2): 64-67.

Stover RH (1962). Fusarial wilt (Panama Disease) of bananas and other Musa species. Oxford university press, Oxford, UK.

Stover RH, Simmonds NW (1987). Bananas, third edition. Longman Scientific \& Technical, New York, USA.

Stukenbrock EH, McDonald BA (2008). The origins of plant pathogens in agro-ecosystems. Annual Review of Phytopathology 46: 75-100.

Su HJ, Hwang SC, Ko WH (1986). Fusarial wilt of Cavendish bananas in Taiwan. Plant Disease 70(9): 814-818.

Valmayor RV, Jamaluddin SH, Silayoi JSB, et al. (1999). Banana cultivar names and synonyms in Southeast Asia. INIBAP, Montpellier, France.

Vérin P (1981). Madagascar. In: General History of Africa. II, Ancient Civilization of Africa (Mokhtar G, eds). Unesco University of California Press, USA: 693-717.

Waite BH, Stover RH (1960). Studies on Fusarium wilt of bananas. VI. Variability and the cultivars concept in Fusarium oxysporum f. sp. cubense. Canadian Journal of Botany 38: 985-994.

Wollenweber HW, Reinking OA (1935). Die Fusarien, ihre Beschreibung, Schadwirkung, und 677 Bekämpfung. Paul Parey, Berlin.

Zuo C, Deng G, Li B, et al. (2018). Germplasm screening of Musa spp. for resistance to Fusarium oxysporum f. sp. cubense tropical race 4 (Foc TR4). European Journal Plant Pathology, https://doi.org/10.1007/s10658-0171406-3. 


\title{
Chapter 2
}

\section{Phylogeny and genetic diversity of the banana Fusarium wilt pathogen Fusarium oxysporum f. sp. cubense in the Indonesian centre of origin}

\author{
Nani Maryani ${ }^{1,2,}$, Lorenzo Lombard ${ }^{4}$, Yuyu S. Poerba ${ }^{5}$, Siti Subandiyah ${ }^{6}$ \\ Pedro W. Crous ${ }^{4}$, and Gerrit H.J. Kema ${ }^{1,2}$
}

'Biointeractions and Plant Health, Wageningen Plant Research, Wageningen University and Research, Wageningen, The Netherlands; ${ }^{2}$ Laboratory of Phytopathology, Wageningen University and Research, Wageningen, The Netherlands; ${ }^{3}$ Biology Education, Faculty of Education, Universitas Sultan Ageng Tirtayasa (UNTIRTA), Banten, Indonesia; ${ }^{4}$ Westerdijk Fungal Biodiversity Institute, Utrecht, The Netherlands; ${ }^{5}$ Research Centre for Biology, Indonesian Institute of Sciences (LIPI), Cibinong, Indonesia; ${ }^{6}$ Entomology and Phytopathology Department, Gajah Mada University, Yogyakarta, Indonesia 


\begin{abstract}
Fusarium oxysporum f. sp. cubense (Foc), the causal agent of Fusarium wilt or Panama disease on banana, is one of the major constraints in banana production worldwide. Indonesia is the centre of origin for wild and cultivated bananas, which likely co-evolved with Foc. This study explored the widest possible genetic diversity of Foc by sampling across Indonesia at 34 geographically and environmentally different locations in 15 provinces at six islands. This resulted in a comprehensive collection of $\sim 200$ isolates from 40 different local banana varieties. Isolates were identified and assessed using sequence analysis of the translation elongation factor-1alpha (tef1), the RNA polymerase II largest subunit (rpb1), and the RNA polymerase II second largest subunit (rpb2). Phylogenetic analyses of these genes allowed the identification of 180 isolates of Fusarium oxysporum f. sp. cubense (Foc), and 20 isolates of the Fusarium fujikuroi species complex (FFSC), the Fusarium incarnatum-equiseti species complex (FIESC), and the Fusarium sambucinum species complex (FSSC). Further analyses, incorporating a worldwide collection of Foc strains, revealed nine independent genetic lineages for Foc, and one novel clade in the Fusarium oxysporum species complex (FOSC). Selected isolates from each lineage were tested on the banana varieties Gros Michel and Cavendish to characterise their pathogenicity profiles. More than $65 \%$ of the isolates were diagnosed as Tropical Race 4 (TR4) due to their pathogenicity to Cavendish banana, which supports the hypothesis that TR4 is of Indonesian origin. Nine independent genetic lineages for Foc are formally described in this study. This biodiversity has not been studied since the initial description of Foc in 1919. This study provides a detailed overview of the complexity of Fusarium wilt on banana and its diversity and distribution across Indonesia.
\end{abstract}

Key words: morphology, new species, panama disease, pathogenicity, Tropical Race 4, 11 new taxa

Taxonomic novelties: New species: Fusarium cugenangense N. Maryani, L. Lombard, Kema \& Crous; F. duoseptatum N. Maryani, L. Lombard, Kema \& Crous; F. grosmichelii N. Maryani, L. Lombard, Kema \& Crous; F. hexaseptatum N. Maryani, L. Lombard, Kema \& Crous; F. kalimantanense N. Maryani, L. Lombard, Kema \& Crous; F. odoratissimum N. Maryani, L. Lombard, Kema \& Crous; F. phialophorum N. Maryani, L. Lombard, Kema \& Crous; F. purpurascens N. Maryani, L. Lombard, Kema \& Crous; F. sangayamense N. Maryani, L. Lombard, Kema \& Crous; F. tardichlamydosporum N. Maryani, L. Lombard, Kema \& Crous; F. tardicrescens N. Maryani, L. Lombard, Kema \& Crous 


\section{INTRODUCTION}

Indonesia is one of the main centres of origin for banana in South-East Asia (Valmayor 1999). Edible banana cultivars are descendants from two ancestral wild Musa species, Musa acuminata Colla (AA, $2 n=22)$ and Musa balbisiana Colla $(B B, 2 n=22)$ (Simmonds 1962). These diversified into various edible varieties comprising diploids ( $A A, B B$ ), triploids ( $A A A, A A B$, $A B B$ ) and tetraploids (ABBB). Indonesia is the main contact area between species and subspecies of wild banana in sub-centres of diversity (Perrier et al. 2011) and, therefore, represents the primary gene centre for banana, resulting in a huge phenotypic and genotypic diversity. Indonesia is among the top 10 banana producing countries (FAOSTAT 2017) with over 200 varieties that are presently grown in almost every region of the Indonesian archipelago (Nasution 1993). The actual number of identified cultivated banana varieties could easily surpass 500. Banana is one of Indonesia's primary fruit commodities (BPS 2017), with most production supplying the domestic market.

Despite this great diversity and high popularity of bananas, there are some constraints on production. The most important of these is fungal diseases, including Fusarium wilt, also known as Panama disease (Stover 1962a). Fusarium wilt is caused by the soil-borne fungus Fusarium oxysporum f. sp. cubense (Foc), which first appeared in the 1900s in a banana plantation on Java (Stover 1962a) and thereafter disseminated to other banana production areas in Indonesia and beyond. This devastating agent of wilt on banana was first reported in the literature from samples collected in a Cuban banana plantation, and it subsequently gained notoriety as Fusarium cubense (Smith 1910).

The history of Fusarium wilt on banana goes back to the 20th century when this disease eliminated thousands of hectares of the favoured Gros Michel banana in Central America. The outbreak evolved into one of the worst epidemics of plant disease of all times. The discovery of resistant Cavendish bananas eventually quenched the epidemic and the variety was so successful that it was disseminated around the world until it attained its current predominance in the global banana trade. The resistance of Cavendish bananas to the socalled Race1 strains, which caused the epidemic in Gros Michel is unique and durable. The risk of global monocultures is evident and problems surfaced again once other pathogenic Fusarium oxysporum strains appeared that were able to cause Fusarium wilt in Cavendish plantations. A harmful strain was initially reported from Taiwan, from whence it spread further into South-East Asia, and recently to the Indian subcontinent, the Middle East and Africa (Ordóñez et al. 2015). The ongoing epidemic in Cavendish bananas is caused by a unique genotype, Vegetative Compatibility Group (VCG) 01213, of Foc and is called Tropical Race 4 (TR4). It has caused significant losses in commercial and subsistence production areas of Taiwan, Malaysia, and the northern territories of Australia (Su et al. 1986, Gerlach et al. 2000, Hermanto et al. 2009). In Indonesia, Nasir et al. (1999) reported that Fusarium wilt occurred from the Aceh province of Sumatra in the far west, to the far eastern Papua province. 
Losses in export Cavendish plantations in southern Sumatra have exceeded $70 \%$. In Northern Sumatra over 1000 ha of plantations were destroyed within $3 \mathrm{yr}$ after the appearance of the disease in this area (Nasir et al. 1999). Not only was Cavendish affected, but also many local popular varieties named in Bahasa Indonesia with 'Pisang' (= 'banana') variety names, such as Pisang Raja Bulu, P. Raja Sereh, P. Ambon, P. Mas and P. Barangan, were damaged. The affected varieties are very important for the local markets (Hermanto et al. 2009).

To date, no control method has yet been identified or successfully implemented to effectively manage TR4. This is further complicated by the soil-borne nature of Foc and its ability to produce persistent chlamydospores that contaminate soils for decades (Booth 1971). Essentially, there are presently no control methods, except prevention by using pathogen-free tissue culture plants planted in non-infested soil (Ploetz 1994), and the adoption of quarantine strategies. However, these practices are mostly applied in large commercial plantations, but not in smallholder settings. Evidently, the development of new resistant banana cultivars would be the most effective control strategy to follow, and therefore research on the diversity of this pathogen is essential, particularly since it has been shown to be polyphyletic (O'Donnell et al. 1998). It is therefore essential to acquire a better understanding of the differences between the genetic lineages for developing control strategies, and for effective resistance breeding.

In Fusarium systematics, Foc belongs to the Fusarium oxysporum species complex (FOSC). Four clades of FOSC have been identified using translation elongation factor 1-alpha (tef1) and mitochondrial subunit rDNA (mtssu), with Foc isolates clustering as basal lineage (O'Donnell et al. 2004). The incorporation of Foc isolates from native host populations, especially those from indigenous ecosystems, will be of great importance for diversity studies of this complex species.

Diversity studies of Foc isolates were conducted by using various physiological and molecular methods, which included Vegetative Compatibility Groups (VCGs; Moore et al. 1993), random amplified polymorphic DNA markers (RAPDs; Bentley et al. 1995), restriction fragment length polymorphisms (RFLPs; Koenig et al. 1997), amplified fragment length polymorphism (AFLP; Groenewald et al. 2006) and DNA sequence analyses (O'Donnell et al. 1998). These studies showed that the South-East Asian population of this fungus exhibits a high degree of variation, suggesting that Foc lineages co-evolved with their hosts in SouthEast Asia (Ploetz \& Pegg 1997). However, these studies used Foc isolates from various disconnected geographical areas and lacked evidence on genetic diversity from the gene centre of banana diversity, which is likely also the origin of the co-evolving Foc (Buddenhagen 2007). It has alternatively been suggested that Foc has multiple independent evolutionary origins, both within and outside the Musa genetic centre (Bentley et al. 1998). Using the phylogenetic genealogical approach, O’Donnell et al. (1998) identified five independent genetic lineages of Foc in a global population. Using a similar approach and additional data, 
Fourie et al. (2009) found three additional lineages. However, neither of these studies included Indonesian populations, and hence only limited information is available on the diversity of Foc in the centre of origin of banana.

Here, we explore the genetic diversity among Indonesian Foc strains that were isolated from local banana varieties in various different ecosystems across the country. This overview of the complexity of Fusarium wilt of banana enables us to greatly improve our knowledge of the taxonomic and phylogenetic position of Foc in the FOSC.

\section{MATERIALS AND METHODS}

\section{Isolates}

A comprehensive survey of Fusarium wilt of banana was undertaken in Indonesia. In total, 34 locations in 15 provinces were visited, representing the main banana-producing regions in Java, Sumatra, Kalimantan, Sulawesi, Papua, and Nusa Tenggara (Table 1, Fig. 1). Sampling expeditions to the former three islands were undertaken in 2014, whereas the other islands were sampled in 2015. Sampling locations were identified in two to three different regions in each province. Diagnostic specimen was collected from diseased banana plants displaying typical Fusarium wilt symptoms: yellowing of older leaf margins, collapsed leaves at the petioles, and pseudostem discolouration and splitting. The pseudostems of the diseased plants were cut and discoloured vascular strands were sampled and placed on sterile filter paper to dry, and were eventually packed in a paper envelope. Global positioning coordinates were recorded and ecological parameters, including soil $\mathrm{pH}$, light intensity and vegetation of the sampling area were collected at each site. For each banana plant sampled, the youngest (cigar) leaf was taken for ploidy identification of the germplasm by flow-cytometry analyses and morphological characterisation following Valmayor (1999) and Simmonds \& Shepherd (1955), as well as in-situ comparisons with local banana varieties in the Musa collection at the Indonesian Institute of Sciences (LIPI) Cibinong, Bogor, Indonesia.

\section{Isolation}

The dried pseudostem samples were cut into pieces of $2 \times 3 \mathrm{~cm}$ and plated on Komada medium (Komada 1975). After approximately 2 d, fungal colonies resembling Fusarium were transferred to potato dextrose agar (PDA) plates (Leslie \& Summerell 2006). Axenic cultures were derived by streaking a small amount of conidia, collected with the tip of an inoculation needle, on water agar (WA) plates, which allowed conidia to separate. After $24 \mathrm{~h}$ of incubation, plates were observed under a dissection microscope at 50× magnification and single germinating conidia were collected and transferred to PDA. Monospore isolates were either maintained on PDA or in $20 \%(\mathrm{v} / \mathrm{v})$ glycerol at $-80{ }^{\circ} \mathrm{C}$. All isolates were deposited in the Indonesian Culture Collection (InaCC) Cibinong, Indonesia. Twenty-four Foc isolates, 
representing the known VCG's (Ordóñez et al. 2015) in the global Foc collection were included for phylogenetic analyses.

Table 1. Names and geographical details of 34 sampling locations in Indonesia for building the Indonesian Fusarium oxysporum f. sp. cubense collection.

\begin{tabular}{|c|c|c|c|c|}
\hline \multirow{2}{*}{ Province } & \multirow{2}{*}{ District } & \multicolumn{3}{|c|}{ GPS } \\
\hline & & Long. & Lat. & Alt. (m) \\
\hline \multirow[t]{2}{*}{ East Kalimantan } & Kutai Timur & 117.62 & 0.68 & 57 \\
\hline & Benajam & 116.77 & -1.62 & 21 \\
\hline \multirow[t]{3}{*}{ Central Kalimantan } & Kapuas Timur & 114.48 & -3.10 & 16 \\
\hline & Katingan & 113.42 & -1.71 & 35 \\
\hline & Palangkaraya & 114.02 & -2.43 & 18 \\
\hline \multirow[t]{3}{*}{ South Kalimantan } & Kota Baru & 116.22 & -2.58 & 118 \\
\hline & Tanah Bumbu & 115.74 & -3.63 & 13 \\
\hline & Banjar & 115.03 & -3.41 & 34 \\
\hline \multirow[t]{2}{*}{ West Kalimantan } & Kubu Raya & 109.29 & -0.06 & 8 \\
\hline & Pontianak & 109.34 & -0.04 & 17 \\
\hline \multirow[t]{3}{*}{ West Java } & Bogor & 107.10 & -6.68 & 657 \\
\hline & Cianjur & 107.10 & -7.02 & 875 \\
\hline & Sukabumi & 106.79 & -7.01 & 263 \\
\hline \multirow[t]{3}{*}{ Central Java } & Kendal & 110.35 & -7.20 & 794 \\
\hline & Semarang & 110.59 & -7.00 & 9 \\
\hline & Demak & 110.74 & -7.06 & 21 \\
\hline \multirow[t]{4}{*}{ East Java } & Lumajang & 113.11 & -8.08 & 637 \\
\hline & Bondowoso & 113.94 & -8.09 & 379 \\
\hline & Purwodadi & 112.75 & -7.82 & 491 \\
\hline & Jember & 113.68 & -8.24 & 39 \\
\hline Aceh & Jantho Aceh Besar & 95.63 & 5.35 & 133 \\
\hline \multirow[t]{2}{*}{ North Sumatra } & Karo & 98.25 & 3.00 & NA \\
\hline & Brastagi & 98.51 & 3.19 & NA \\
\hline \multirow[t]{2}{*}{ West Sumatra } & Bukit Tinggi & 100.38 & -0.29 & NA \\
\hline & Padang & 100.35 & -0.94 & NA \\
\hline \multirow[t]{2}{*}{ South Sumatra } & Ogan Ilir & 104.70 & -3.29 & 27 \\
\hline & Palembang & 104.75 & -2.99 & NA \\
\hline Lampung & Way Jepara & 105.54 & -5.56 & NA \\
\hline Papua & Sentani Jayapura & 140.83 & -2.65 & NA \\
\hline \multirow[t]{4}{*}{ South Sulawesi } & Barru & 119.62 & -4.08 & 8 \\
\hline & Bone & 120.02 & -4.62 & 101 \\
\hline & Maros & 119.63 & -5.10 & 48 \\
\hline & Sidreng Rappang & 119.69 & -3.93 & 165 \\
\hline East Nusa Tenggara & Sikka Flores & 122.37 & -8.61 & 20 \\
\hline
\end{tabular}

\section{DNA isolation, amplification and analyses}

Total genomic DNA was extracted from axenic isolates grown for $7 \mathrm{~d}$ on PDA, using the DNA Wizard Magnetic DNA Purification System for Food kit (Promega, USA) following the protocols provided by the manufacturer. Partial gene sequences were determined for the RNA polymerase largest subunit gene (rpb1) using primers RPB1-Fa \& RPB1-G2R (O'Donnell et al. 2010), the RNA polymerase second largest subunit gene ( $r p b 2)$ using primers RPB2-5f2 \& RPB2-7cr (O'Donnell et al. 2010), and the translation elongation factor 1-alpha gene (tef1) using primers EF1 \& EF2 (O’Donnell et al. 1998). Amplicons were sequenced in both directions 
using the same primer pairs as were used for amplification to ensure integrity of the sequences.

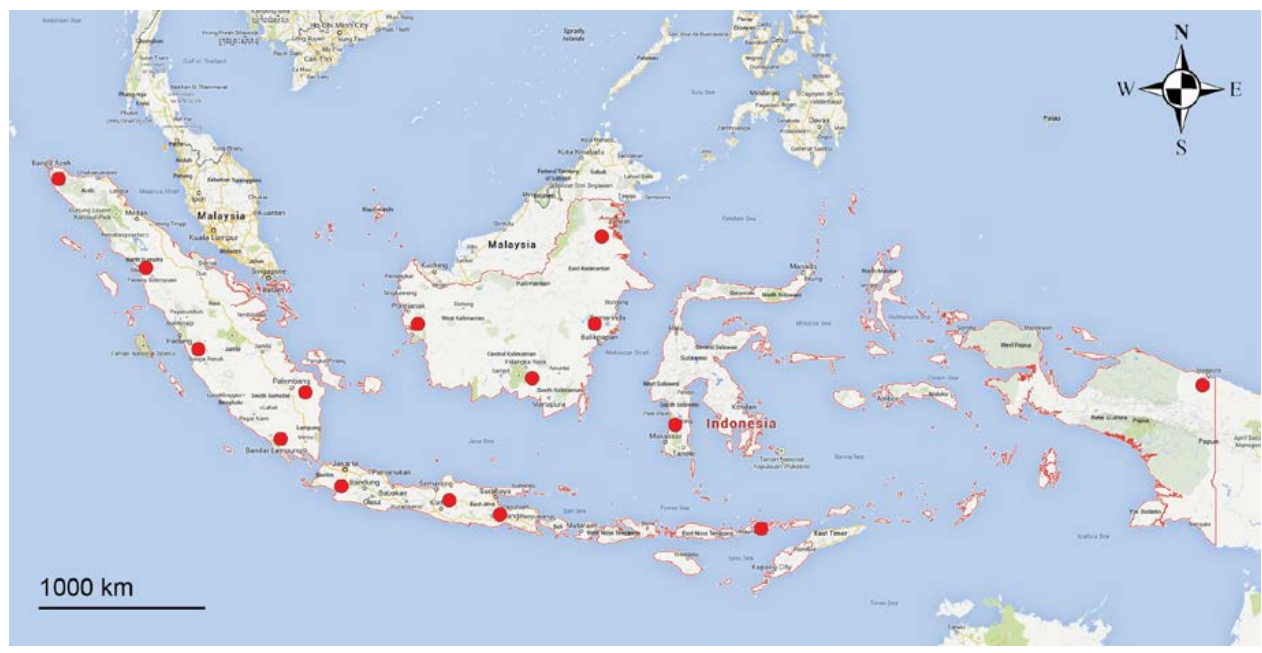

Fig. 1. Map of sampling collection in 2014-2015 on the island of Java, Sumatra, Kalimantan, Sulawesi, Papua, and Flores.

Consensus sequences were determined and assembled using MEGA v. 6 (Tamura et al. 2013) and compared to representative sequences from previous studies (O'Donnell et al. 1998, Fourie et al. 2009, Ordóñez et al. 2015). Subsequent alignments for each individual locus were generated using MAFFT v. 7.110 (Katoh \& Standley 2013) and manually corrected if necessary. The individual sequences generated in this study were compared with those maintained in the Fusarium MLST database (http://www.westerdijkinstitute.nl/fusarium/) and the NCBI's GenBank, and relevant sequences were included in the subsequent phylogenetic inference. Phylogenetic congruencies of the three loci were tested using a $70 \%$ reciprocal bootstrap criterion (Mason-Gamer \& Kellogg 1996).

Phylogenetic inference in this study was based on Maximum Likelihood (ML) and Bayesian Inference (BI). The ML analysis was performed using RAxML v. 8. (randomised accelerated (sic) maximum likelihood for high performance computing) (Stamatakis 2014) through RAxML BlackBox (http://embnet.vital-it.ch/raxml-bb/index.php). Bootstrap support (BS) was determined automatically by the software to assess the robustness of the analyses. The $\mathrm{BI}$ analysis was performed using MrBayes v. 3.2 (Ronquist et al. 2012). A Markov Chain Monte Carlo (MCMC) algorithm of four chains was initiated in parallel from a random tree topology with a heating parameter set at 0.3 . The MCMC analyses lasted until the average standard deviations of split frequencies were below 0.01 with phylogenies saved every 1000 generations. The first $25 \%$ of saved phylogenies were discarded as the "burn-in" phase and posterior probabilities (PP) were determined from the remaining phylogenies. All the 
sequences generated in this study were deposited in the European Nucleotide Archive (ENA) and the alignments in TreeBASE.

\section{Morphology}

All Foc isolates were grown on carnation leaf agar (CLA; Fisher et al. 1982), synthetic lownutrient agar (SNA; Nirenberg 1981) and PDA to induce sporulation under continuous light (Osram L18W/840 Cool White) for $7 \mathrm{~d}$ at $25^{\circ} \mathrm{C}$. Growth rates of all isolates were determined after $7 \mathrm{~d}$ incubation at $25^{\circ} \mathrm{C}$ in the dark on PDA. Colony colours were determined using the mycological colour charts of Rayner (1970). Gross morphological characters, including microconidia, macroconidia, chlamydospores and conidiophores, were examined (50x) after mounting fungal structures in sterile water and observed using light microscopy at $1000 \times$ magnification. For each taxonomically informative structure, the extremes are provided, but for conidia we calculated the $95 \%$ confidence intervals and provide extremes in parentheses. All descriptions, illustrations and nomenclatural data were deposited in MycoBank (Crous et al. 2004).

\section{Pathogenicity assays}

Isolates of Foc clustering in different clades based on the MLST analyses were selected for pathogenicity assays. The TR4 reference strain Focll5-NRRL5006 (Ordóñez et al. 2015) was included as a positive control, and negative controls were treated with water. For all assays, we followed the inoculum production, inoculation and diseases assessment protocols developed by Garcia-Bastidas et al. (2018, in prep.) using 2-3-mo-old Cavendish and Gros Michel plants. Prior and post-inoculation greenhouse conditions were adjusted to a constant day temperature of $25^{\circ} \mathrm{C}$ (ambient light until max. $16 \mathrm{~h}$ ), a night temperature of $23^{\circ} \mathrm{C}$, and a relative humidity of $\geq 75 \%$. After $7 \mathrm{wk}$, disease severities were evaluated by scoring external foliage and internal corm symptoms.

\section{RESULTS}

\section{Isolates}

Symptoms characteristic of Fusarium wilt were observed in most of the sampling locations on a diverse suite of banana varieties in typical backyards and in a Cavendish industrial plantation (Fig. 2). In total, 40 local banana varieties showed Fusarium wilt symptoms and were sampled (Table 2, Fig. 3). However, wild banana species, including Musa acuminata var. bantamensis in West Java, M. acuminata var. rutilifes in the forest of East Java, and M. acuminata var. microcarpa and M. bornensis in Kalimantan, and the Musa-related species, Ensete glaucum in Flores, were consistently free of external Fusarium wilt symptoms. In total, 203 isolates were obtained from the symptomatic banana plants (Table 3 ). 


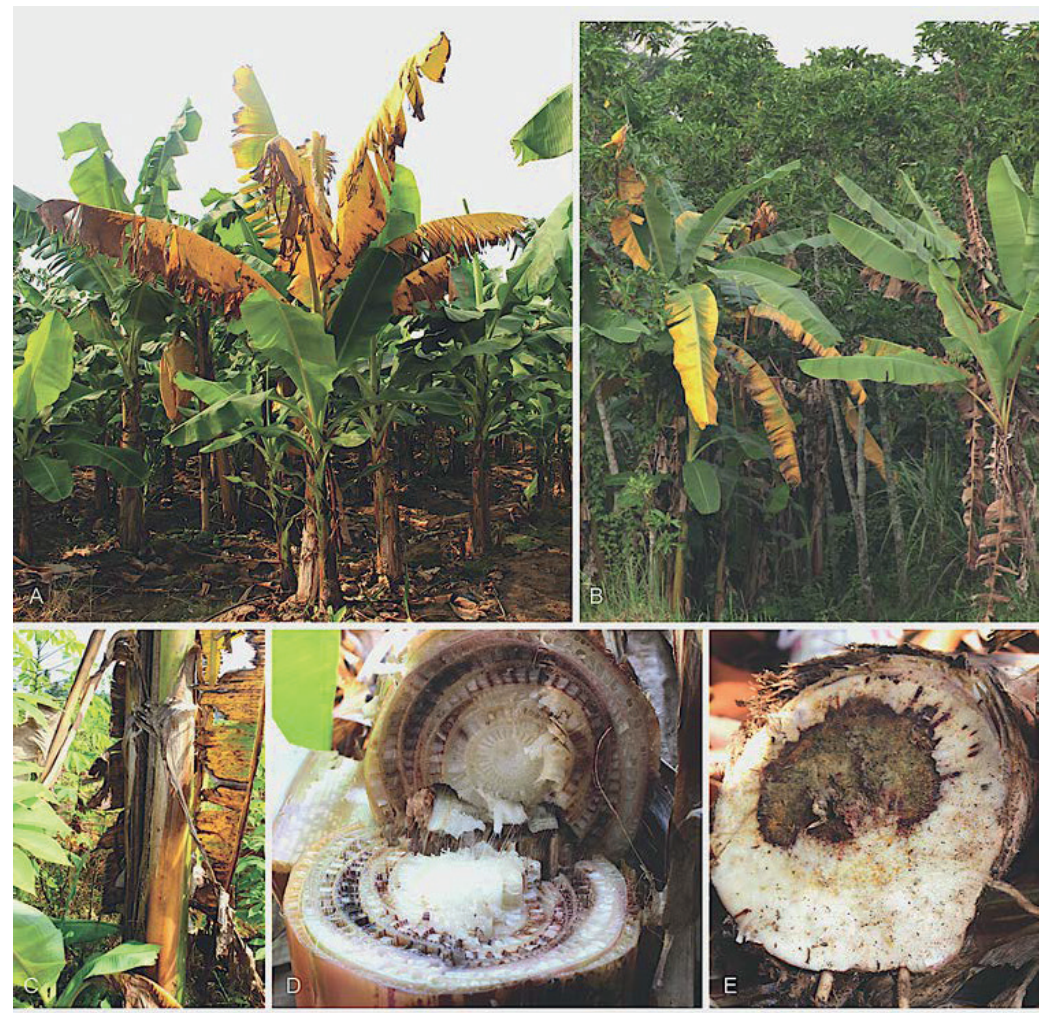

Fig. 2. Symptoms of Fusarium wilt on banana. A. External wilting symptom on leaves in a monoculture plantation in Lampung, Sumatra. B. External wilting symptom on leaves in a backyard home plantation in Cianjur, West Java. C. Splitting of the pseudostem. D. Internal symptoms, discoloration of the pseudostem. E. discoloration of the corm.

\section{Phylogenetic analyses}

Approximately 632 bp were determined for tef1, 864 bp for $r p b 2$ and 1444 bp for the rpb1 gene regions. The congruency analyses revealed no conflicts in tree topologies, with only minor differences in branch support. Therefore, the sequences of the three loci were combined in a single dataset for subsequent analyses. For the $B I$ and $M L$ analyses, a $G T R+I+G$ model was selected for all three gene regions and incorporated into the analyses. The $M L$ tree topology confirmed the tree topologies obtained from the BI analyses, and therefore, only the ML tree is presented.

The combined tef1, rpb1 and $r p b 2$ sequences dataset included 244 ingroup taxa and $F$. dimerum (NRRL 36140) as outgroup taxon. This dataset consisted of 2909 characters, which yielded a single best $M L$ tree with $-\operatorname{InL}=-9286.260647$ (Fig. 4). The $\mathrm{BI}$ lasted for $11 \mathrm{M}$ generations, and the consensus tree, with posterior probabilities, was calculated from 8251 trees left after 2750 trees were discarded as the "burn-in" phase. 
Table 2. List of 40 susceptible local banana varieties at six Indonesian islands from which samples were taken to isolate Fusarium oxysporum f. sp. cubense strains.

\begin{tabular}{|c|c|c|c|c|c|}
\hline \multirow[b]{2}{*}{ Islands } & \multicolumn{3}{|c|}{ Banana varieties } & \multirow[b]{2}{*}{ Scientific name $^{1}$} & \multirow[b]{2}{*}{ Genome $^{1}$} \\
\hline & Local name & Popular name & $\begin{array}{l}\text { International } \\
\text { name }\end{array}$ & & \\
\hline \multirow[t]{7}{*}{ Sumatra } & Pisang Ayam & Pisang Barangan & Lakatan & Musa acuminata & AAA \\
\hline & P. Wak & P. Awak & Awak & Musa sp. & $A B B$ \\
\hline & P. Abe & P. Kepok & Saba & Musa sp. & $A B B$ \\
\hline & P. Talon & P. Raja & Raja & Musa sp. & $A A B$ \\
\hline & P. Barangan & P. Barangan & Lakatan & Musa acuminata & AAA \\
\hline & P. Tanduk Bawen & P. Tanduk & Horn & Musa sp. & $A A B$ \\
\hline & P. Mas & P. Mas & Sucrier & Musa acuminata & AA \\
\hline \multirow[t]{11}{*}{ Kalimantan } & $\begin{array}{l}\text { P. Sanggar/ } \\
\text { Manurun/ Nipah }\end{array}$ & P. Kepok & Saba & Musa sp. & $A B B$ \\
\hline & $\begin{array}{l}\text { P. Awak/ Pulau } \\
\text { Pinang }\end{array}$ & P. Awak & Awak & Musa sp. & $A B B$ \\
\hline & P. Ambon & P. Ambon Hijau & Cavendish & Musa acuminata & AAA \\
\hline & P. Susu & P. Raja Sereh & Silk & Musa sp. & $A A B$ \\
\hline & P. Hawa & P. Awak & Awak & Musa sp. & $A B B$ \\
\hline & P. Gelobok & P. Awak & Awak & Musa sp. & $A B B$ \\
\hline & P. Talas & P. Talas & NA & Musa acuminata & AA \\
\hline & P. Selendang & NA & NA & Musa acuminata & AAA \\
\hline & Dwarf Cavendish & P. Kapal & Dwarf Cavendish & Musa acuminata & AAA \\
\hline & P. Raja & P. Raja Buluh & Raja & Musa sp. & $A A B$ \\
\hline & P. Kepok & P. Kepok & Saba & Musa sp. & $A B B$ \\
\hline \multirow[t]{15}{*}{ Java } & P. Mas Kirana & P. Mas Kirana & Sucrier & Musa acuminata & AA \\
\hline & P. Embuk & NA & NA & Musa sp. & $A A B$ \\
\hline & P. Kongkong & NA & NA & Musa acuminata & AAA \\
\hline & P. Susu & P. Raja Sereh & Silk & Musa sp. & $A A B$ \\
\hline & P. Glintung & NA & NA & - & NA \\
\hline & P. Ambon & P. Ambon Kuning & Gros Michel & Musa acuminata & AAA \\
\hline & P. Ambon Lumut & P. Ambon Hijau & Cavendish & Musa acuminata & AAA \\
\hline & Cau Langadai & P. Siem & NA & Musa sp. & $A B B$ \\
\hline & Cau Apu & P. Siem & NA & Musa sp. & ABBB \\
\hline & P. Jimbluk & P. Siem Jumbo & NA & Musa sp. & ABBB \\
\hline & P. Uli & P. Uli & NA & Musa acuminata & $\mathrm{AA}$ \\
\hline & P. Raja Nangka & P. Nangka & Laknau & Musa acuminata & AAA \\
\hline & P. Cavendish & P. Ambon Hijau & Cavendish & Musa acuminata & AAA \\
\hline & P. Kepok Pipik & P. Kepok Putih & NA & Musa sp. & $A B B$ \\
\hline & P. Raja & P. Raja Buluh & Raja & Musa sp. & $A A B$ \\
\hline \multirow[t]{2}{*}{ Papua } & P. Tanduk & P. Tanduk & Horn & Musa sp. & $A A B$ \\
\hline & P. Raja & P. Raja Buluh & Raja & Musa sp. & $A A B$ \\
\hline \multirow[t]{3}{*}{ Sulawesi } & P. Kepok & P. Kepok & Saba & Musa sp. & $A B B$ \\
\hline & P. Ambon & P. Ambon Hijau & Cavendish & Musa acuminata & AAA \\
\hline & P. Cere & NA & NA & Musa acuminata & AAA \\
\hline East Nusa & P. Kepok & P. Kepok & Saba & Musa sp. & $A B B$ \\
\hline Tenggara & P. Barangan & P. Barangan & Lakatan & Musa acuminata & AAA \\
\hline
\end{tabular}

${ }^{1}$ https://www.crop-diversity.org/mgis/taxonomy 

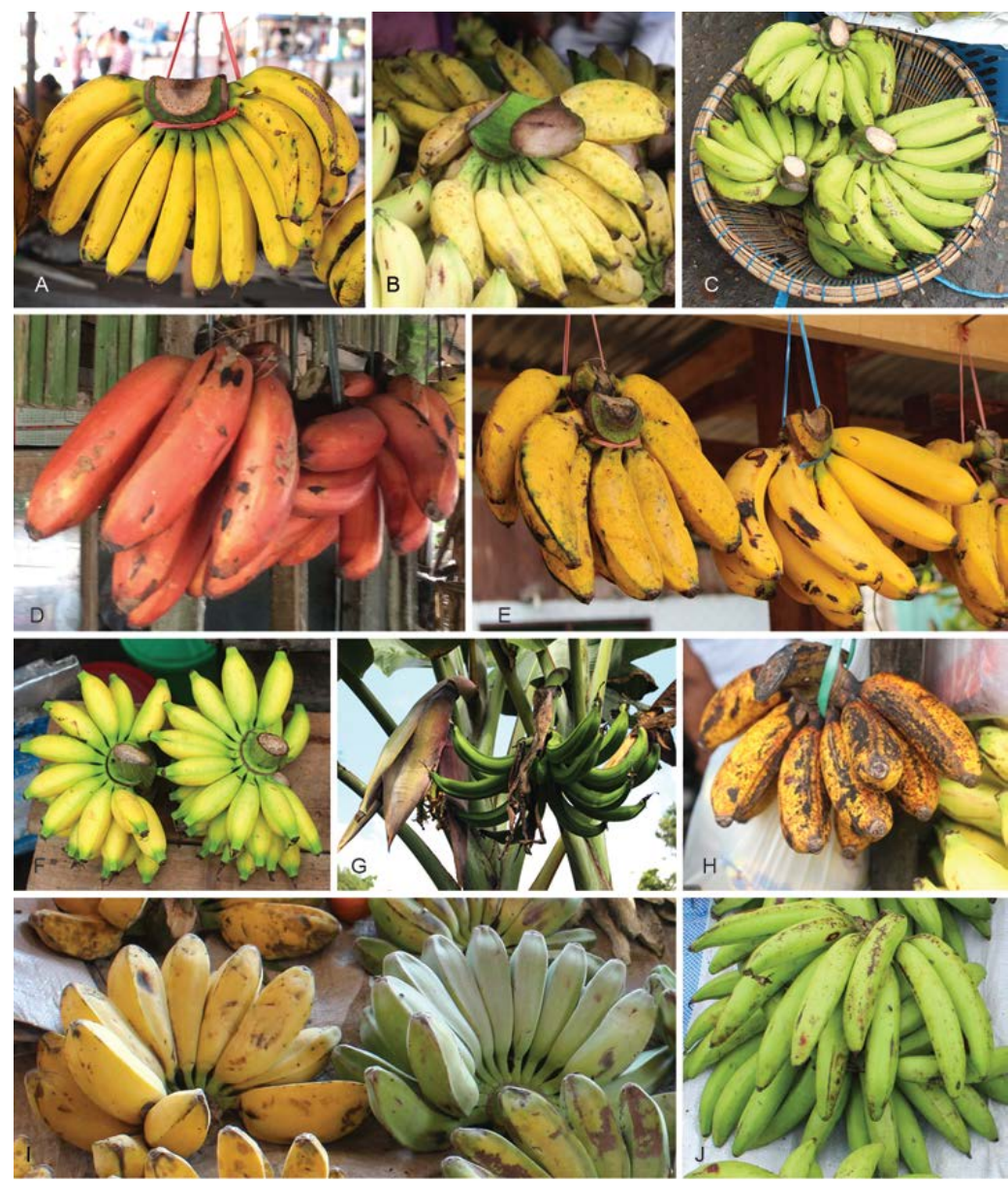

Fig. 3. Local Indonesian banana varieties. A. Pisang Raja Bulu (AAB). B. Pisang Awak (ABB). C. Pisang Ambon Hijau (AAA). D. Pisang Udang (ABB). E. Left, Pisang Raja Manten (AAB), right, Pisang Barangan (AAA). F. Pisang Mas Lampung (AA). G. Pisang Tanduk (AAB). H. Pisang Susu (AAB). I. Pisang Kepok (ABB). J. Pisang Jarum (AA).

Phylogenetic inference of the three gene regions placed all isolates recovered from the symptomatic samples in the genus Fusarium (Fig. 4). Of these, 180 isolates clustered in the FOSC clade, one isolate clustered in the Fusarium sambucinum species complex (FSSC) closely related to $F$. longipes, 11 isolates clustered in the Fusarium incarnatum-equiseti species complex (FIESC), and eight isolates clustered in the Fusarium fujikuroi species complex (FFSC). The highest phylogenetic support was obtained using the tef1 and $r p b 1$ gene regions. The $r p b 2$ gene region displayed less resolution of the isolates, between the various Fusarium species complexes and within each complex. The clades representing FIESC and FSSC resolved in this study were highly supported (BS $=100 \%$; PP $=1$ ). The FFSC resolved FOSC and other members of the FFSC into two highly supported clades (BP = $100 \%$; PP = 1 \& BP = 97\%; PP = 1, respectively). 
In the FOSC, using the single gene analyses of tef1, and after incorporation of the dataset of O'Donnell et al. (2004) and Fourie et al. (2009), two clades were resolved as in the previous study (O'Donnell et al. 2004; Fig. 5). None of the Indonesian isolates resided in Clade 3. A single isolate, representing FocCNPMF.R1 (Dita et al. 2010), clustered in the FOSC Clade 4. The phylogeny, however, revealed one new clade in the FOSC ( $B P=100 \%, P P=1.0$ ), assigned to FOSC Clade 5, comprising five isolates that were isolated from Pisang Kepok $(A B B, 2 n=33$ ) and Pisang Ambon (AAA, $2 n=33$ ) in Central and South Kalimantan.

Further analyses of the Foc phylogeny using the combined tef1, rpb1 and rpb2 dataset included 216 ingroup taxa and F. fujikuroi (CBS 221.76.) as an outgroup taxon (Fig. 5). The majority of Indonesian isolates clustered in Clade 1, including eight previously established Foc lineages (Fig. 5; O'Donnell et al. 1998, Fourie et al. 2009), and the overall phylogeny revealed nine independent clonal lineages (Fig. 6). The Indonesian Foc isolates were equally distributed across the nine lineages except for $L 9$ that did not include any Indonesian isolate. We did not identify significant correlation between the origin of the isolates and host genotypes.

\section{Taxonomy}

Based on phylogenetic inference and morphological observations, several novel Fusarium taxa could be identified in this study, and these are described below.

\section{Foc Lineage L1}

Fusarium odoratissimum N. Maryani, L. Lombard, Kema \& Crous, sp. nov. MycoBank MB826800. Figs 7, 8.

Etymology: Name refers to the strong odour associated with older cultures.

Macroconidia abundant on CLA, less abundant on PDA and SNA, formed on sporodochia on CLA and on aerial conidiophores on SNA and PDA, falcate, (44-)59-75(-79) × 6-8 $\mu \mathrm{m}$ (av. 67 $\times 7 \mu \mathrm{m}), 0-6$-septate, with apical cells papillate, basal cells foot-shaped. Conidiogenous cells mono- or polyphialidic on sporodochia, or formed directly on hyphae (lateral phialides), 12 $28 \times 4-8 \mu \mathrm{m}$. Microconidia abundant on PDA and SNA, less frequent on CLA, oval to ellipsoid, $(6-) 8-16(-23) \times(4-) 6(-8) \mu \mathrm{m}$ (av. $12 \times 5 \mu \mathrm{m}$ ), 0-3-septate, arranged in false heads on branched conidiophores carried on hyphae. Aerial conidiophores rare on CLA and SNA but formed abundantly on PDA, branched sparsely or formed laterally. Chlamydospores globose to subglobose, formed intercalarily or terminally, single or in pairs, (7-)9-13(-14) $\times(7-) 8-11(-$ 12) $\mu \mathrm{m}$, rarely produced on SNA after $7 d$, rough-walled. 


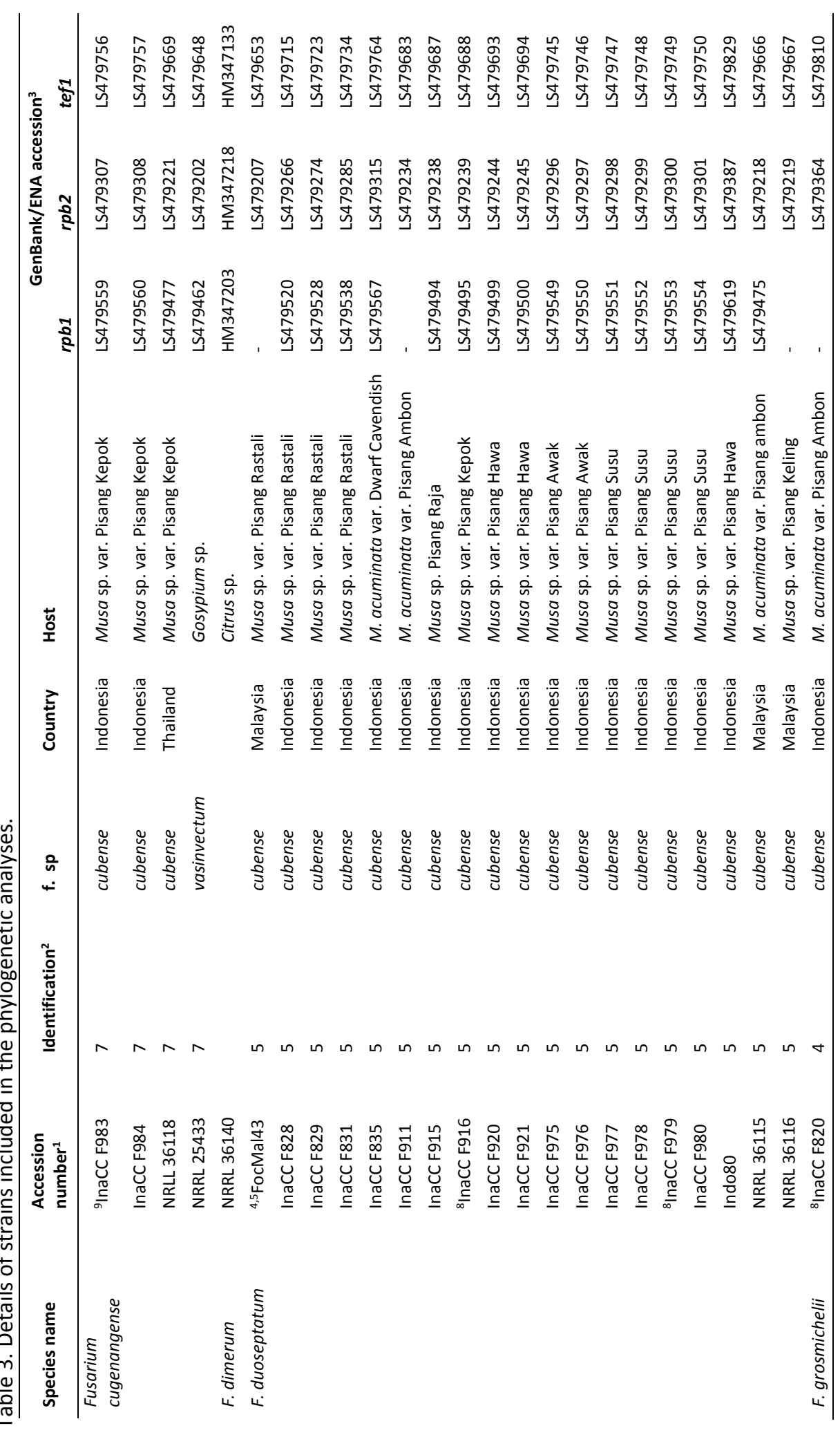




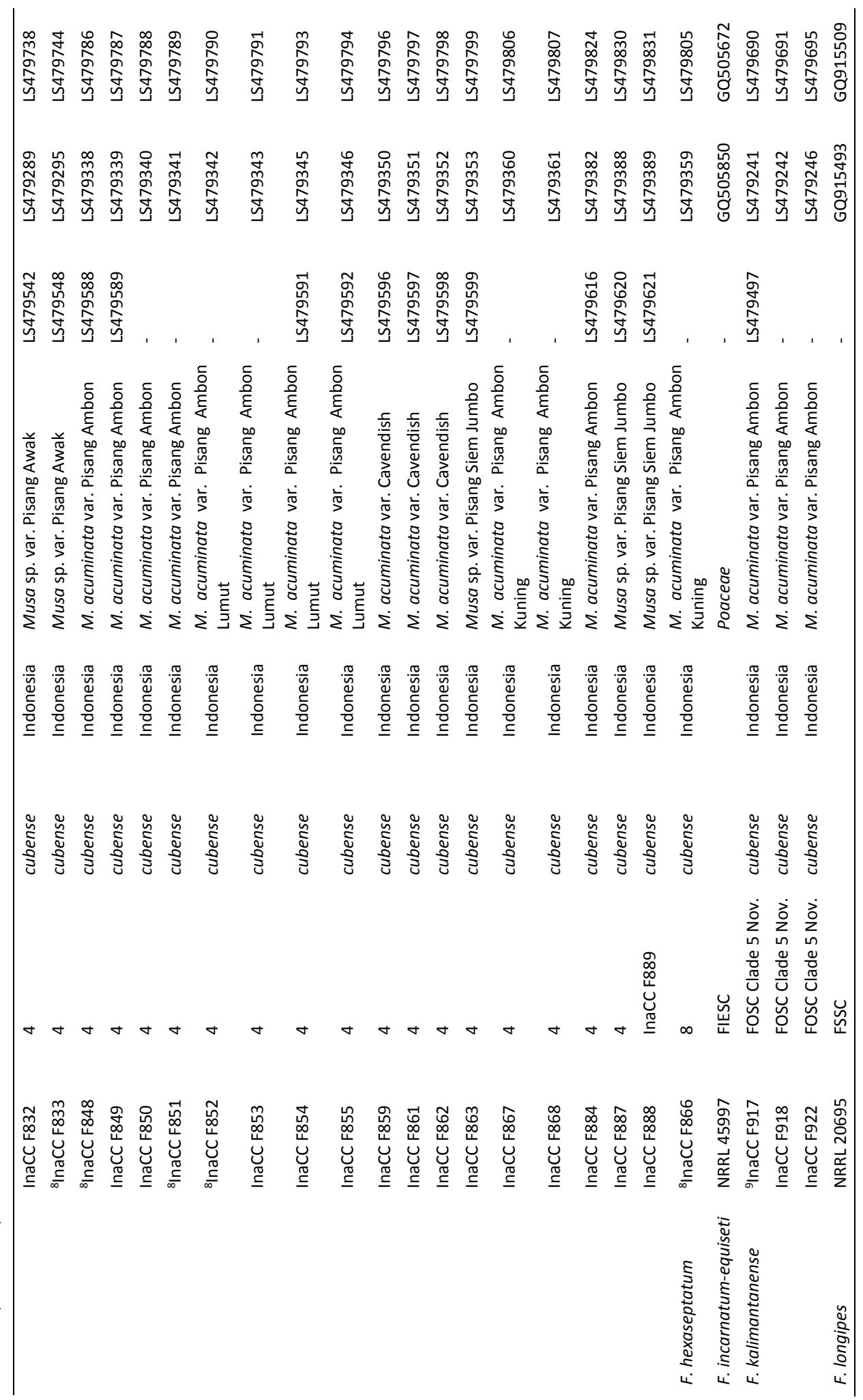




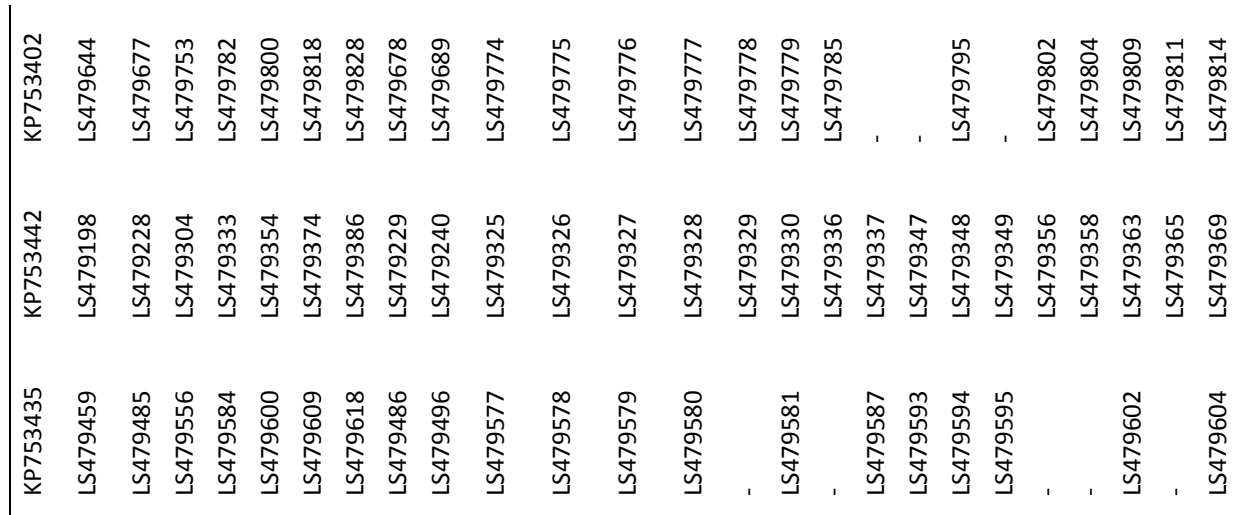

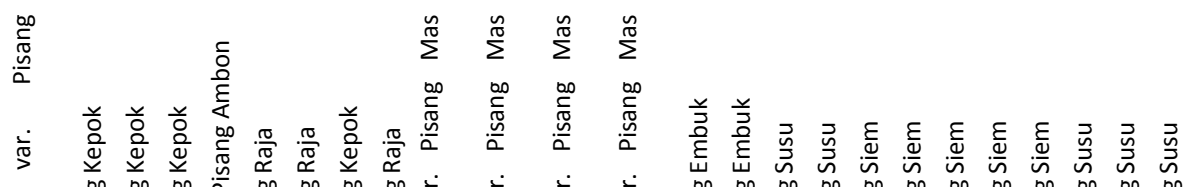

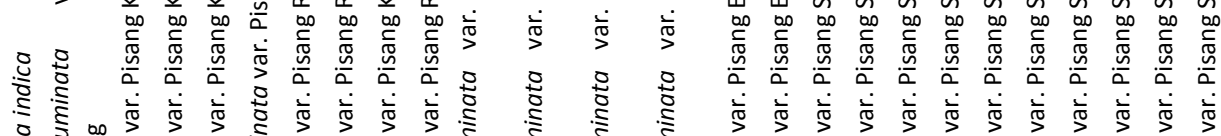

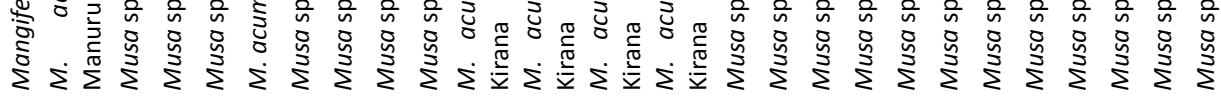

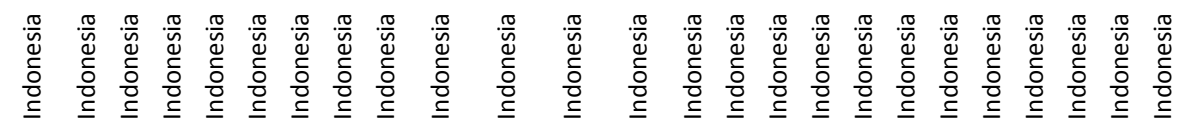

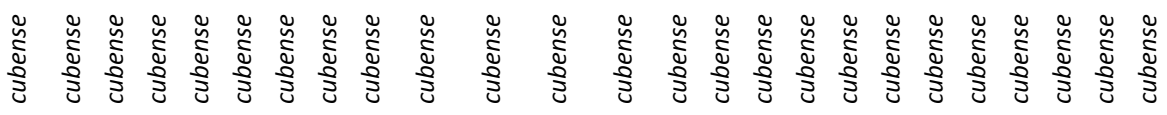
若

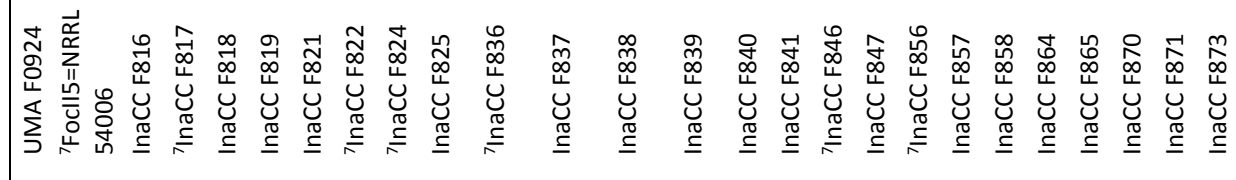

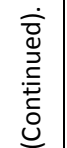

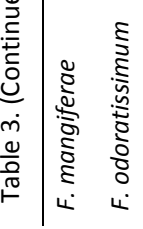




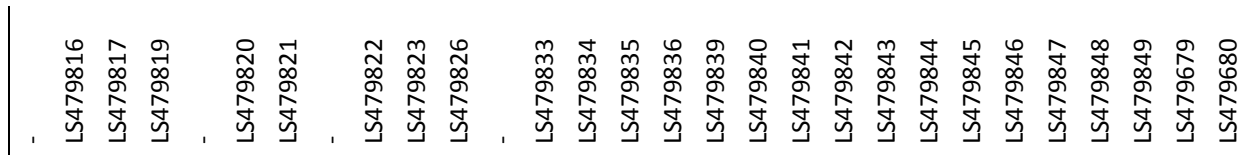

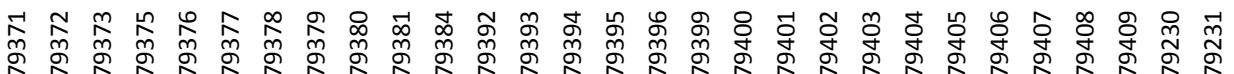

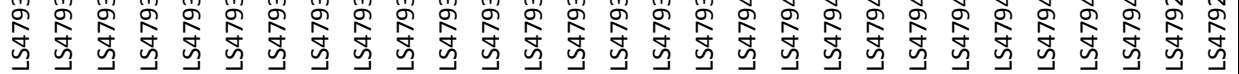

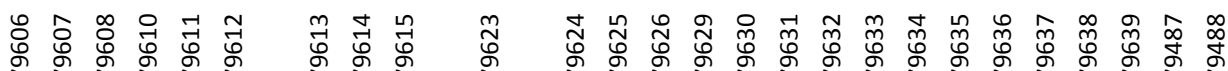

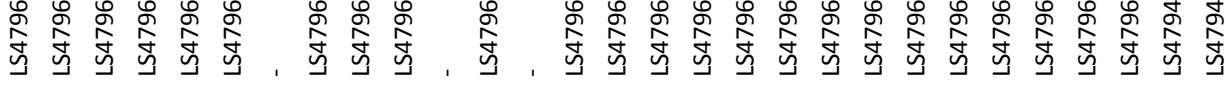

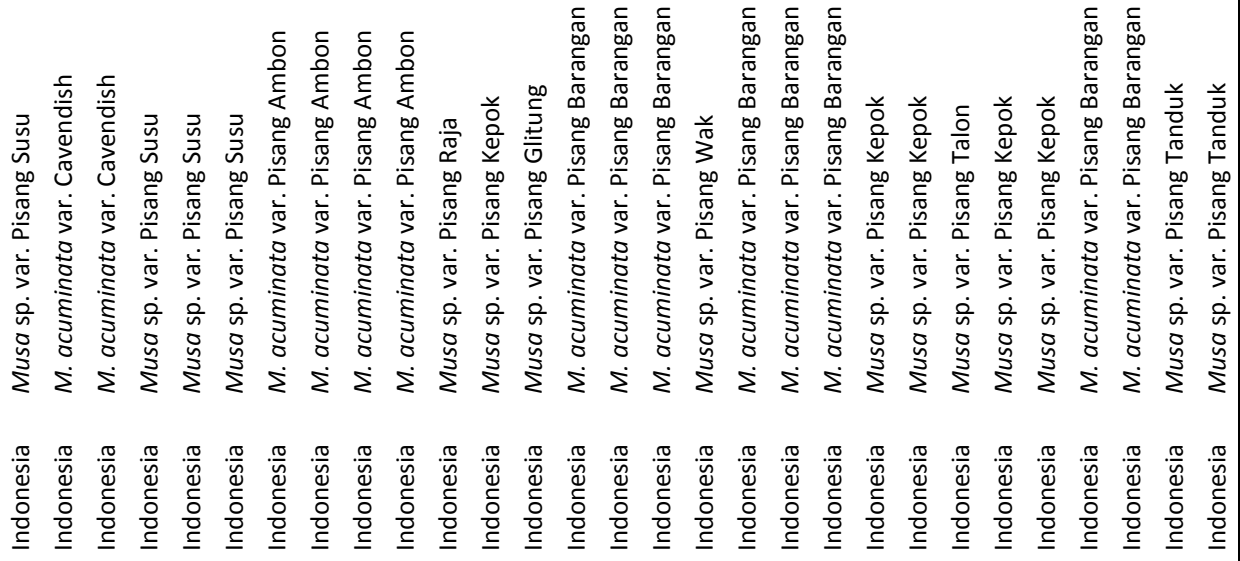

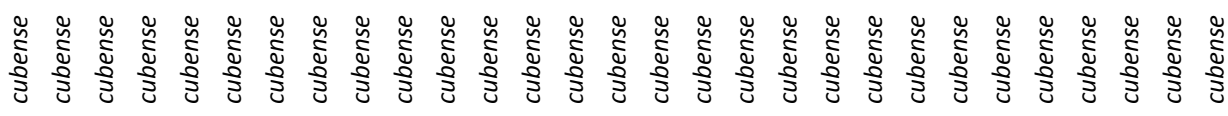

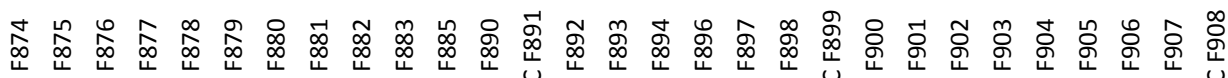

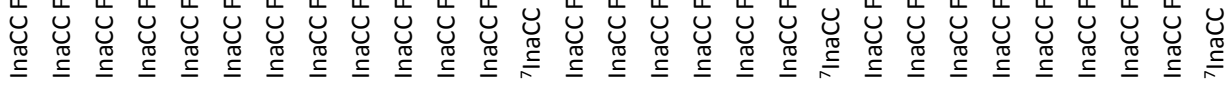




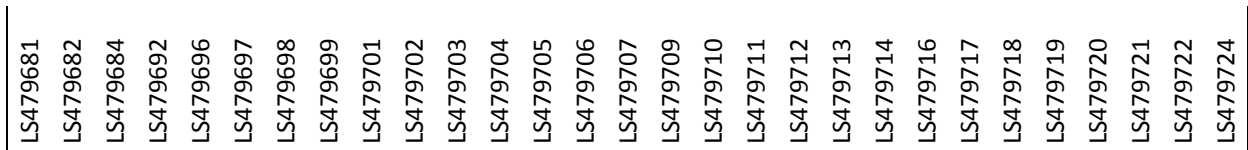
苂

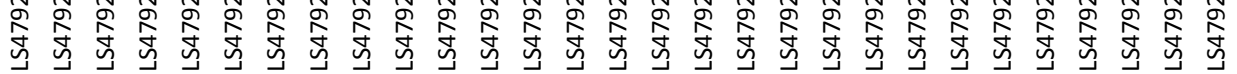

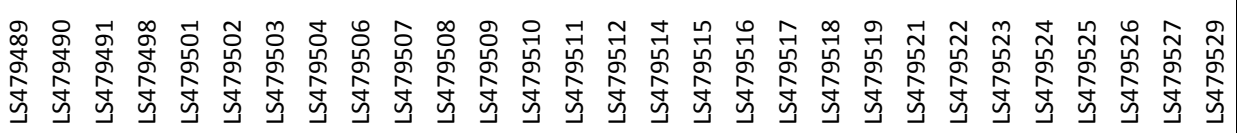

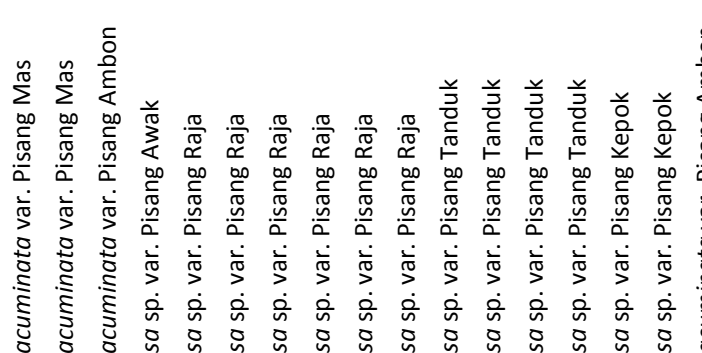

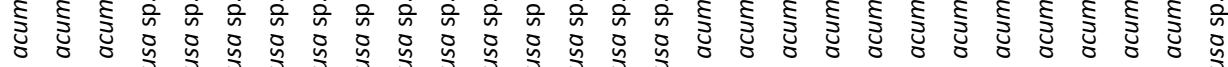

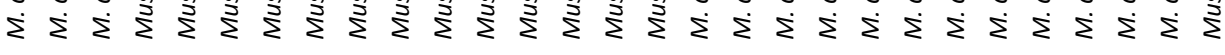

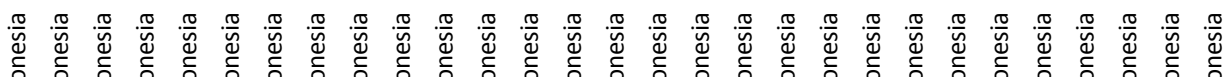

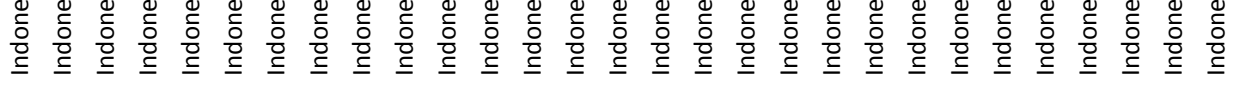

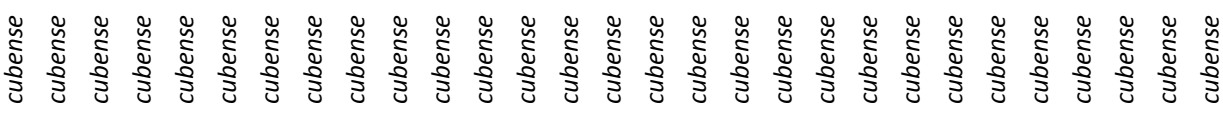

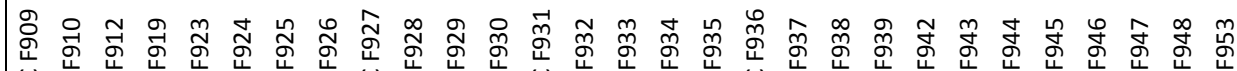

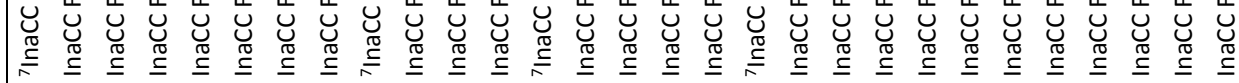

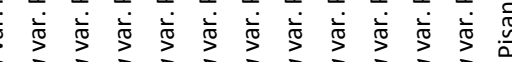




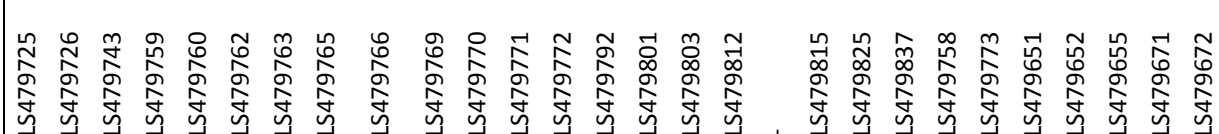

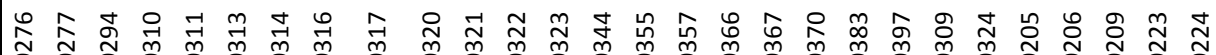
光

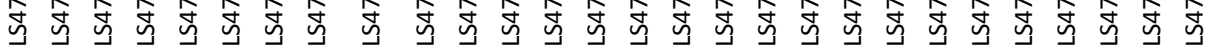

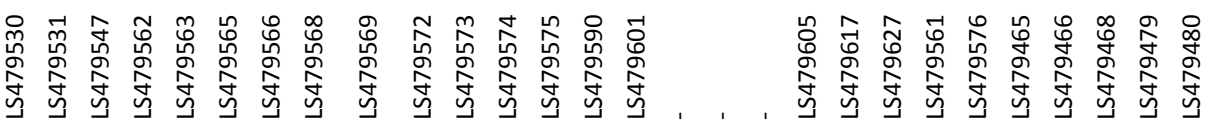

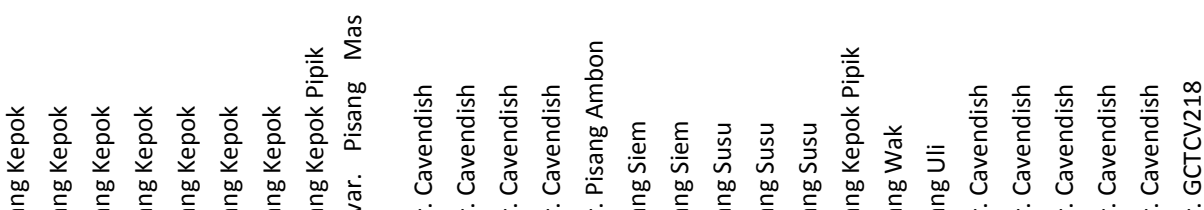

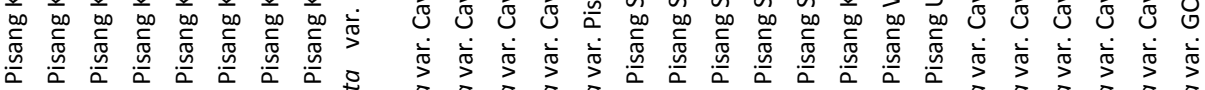

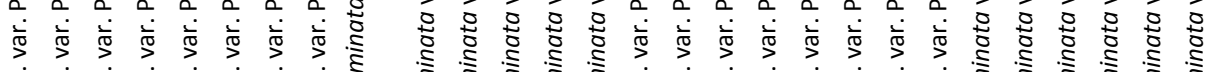

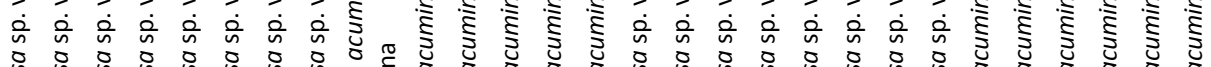

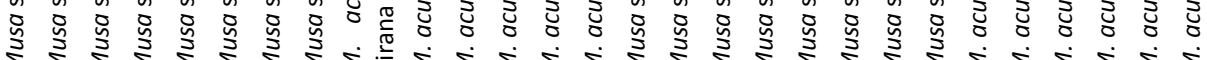

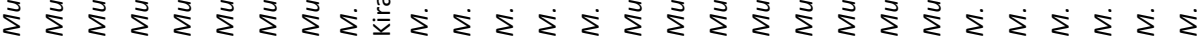

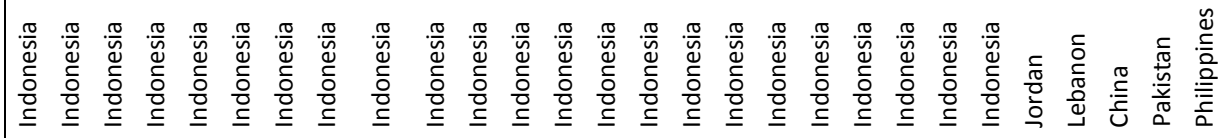

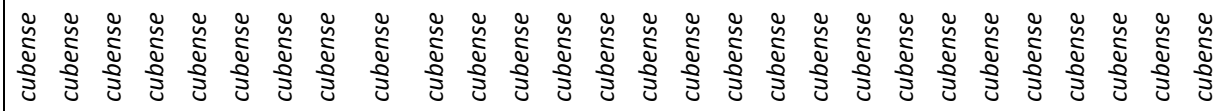

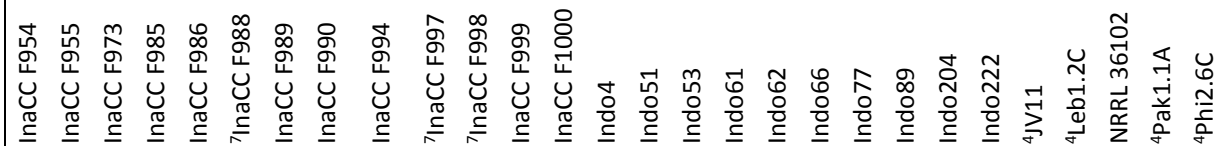




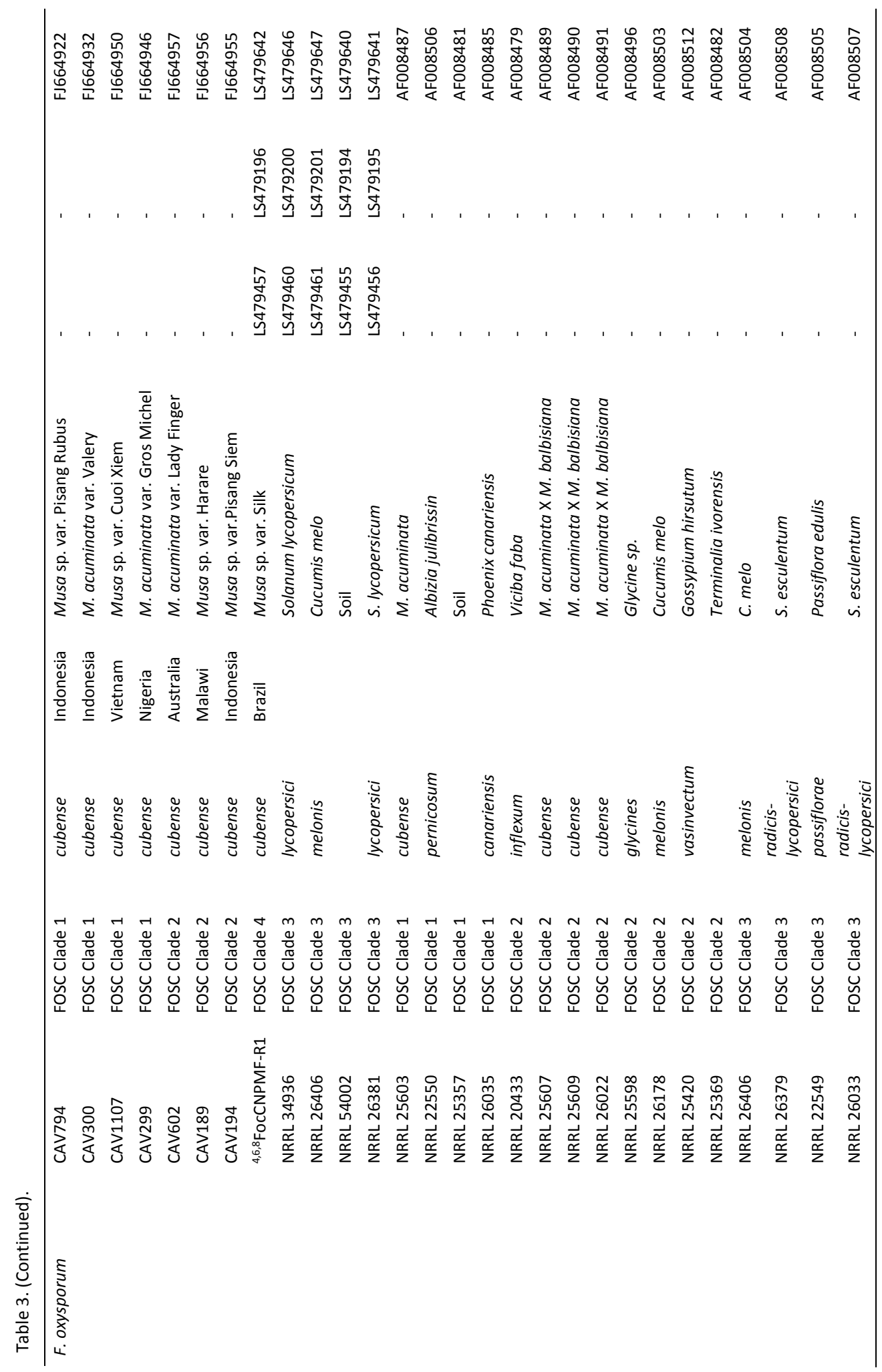




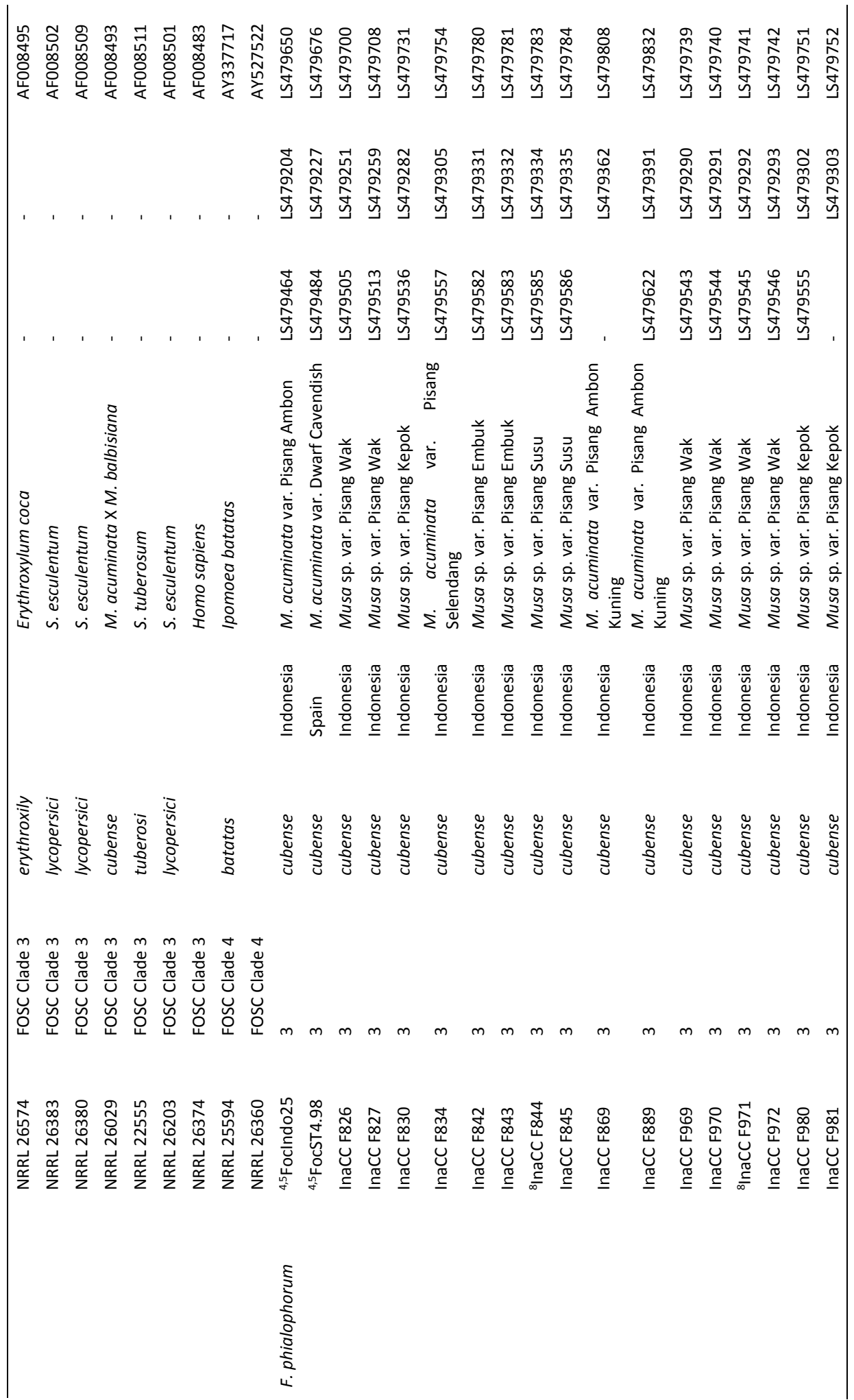




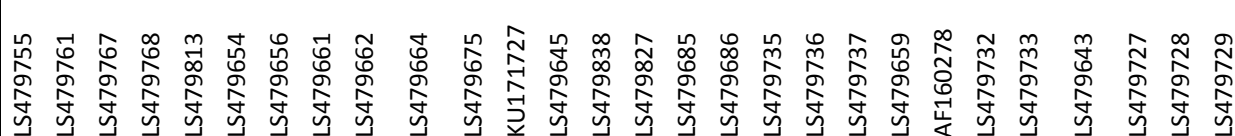

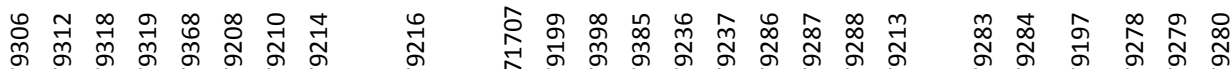

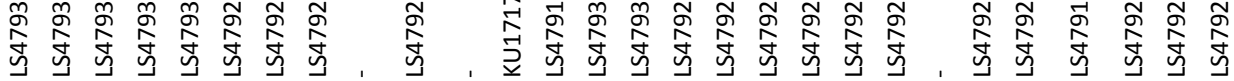

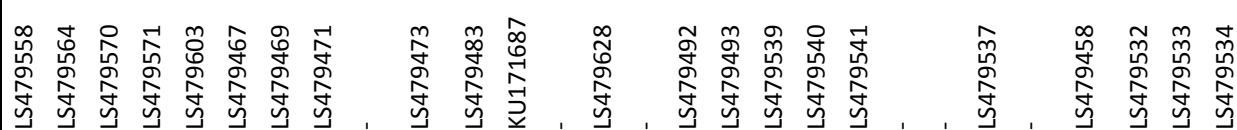

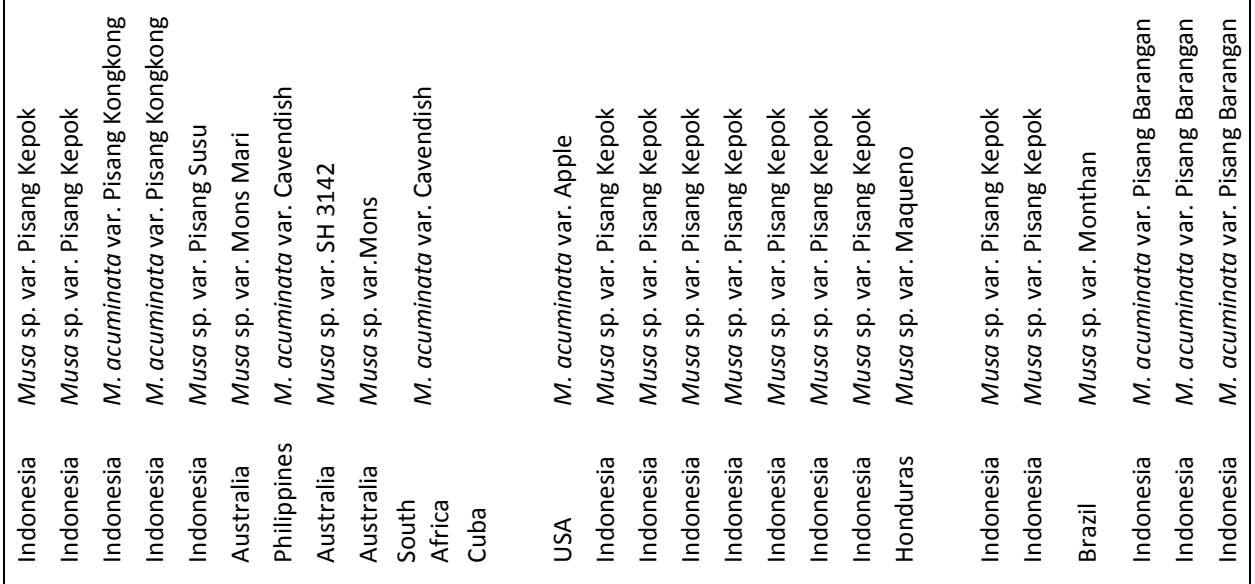

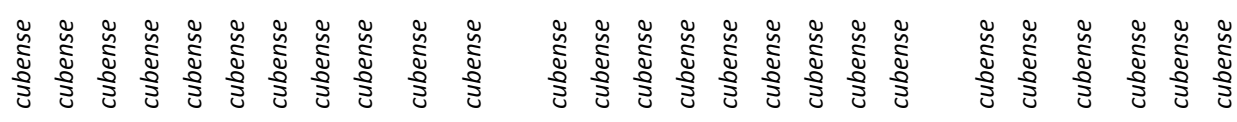

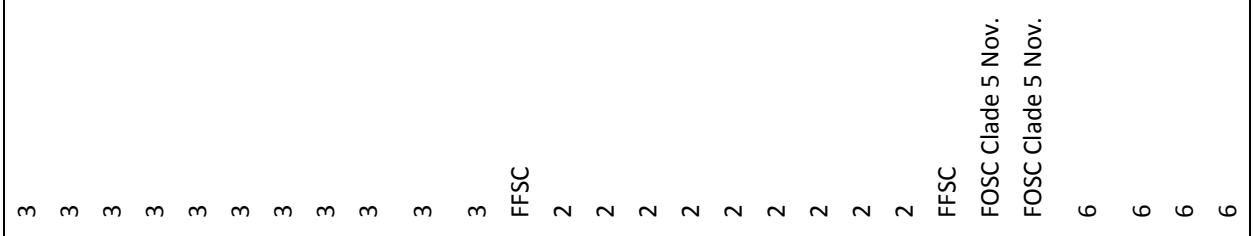

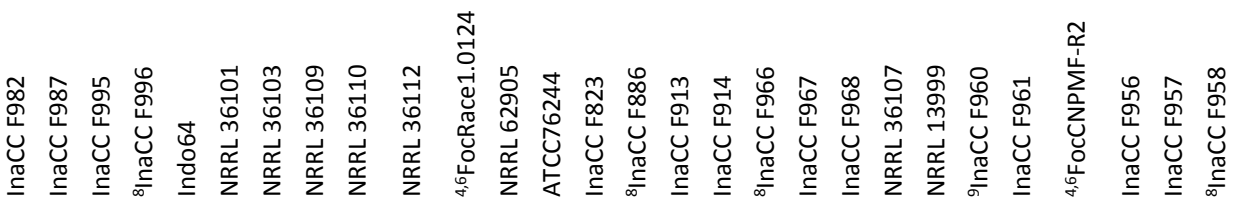




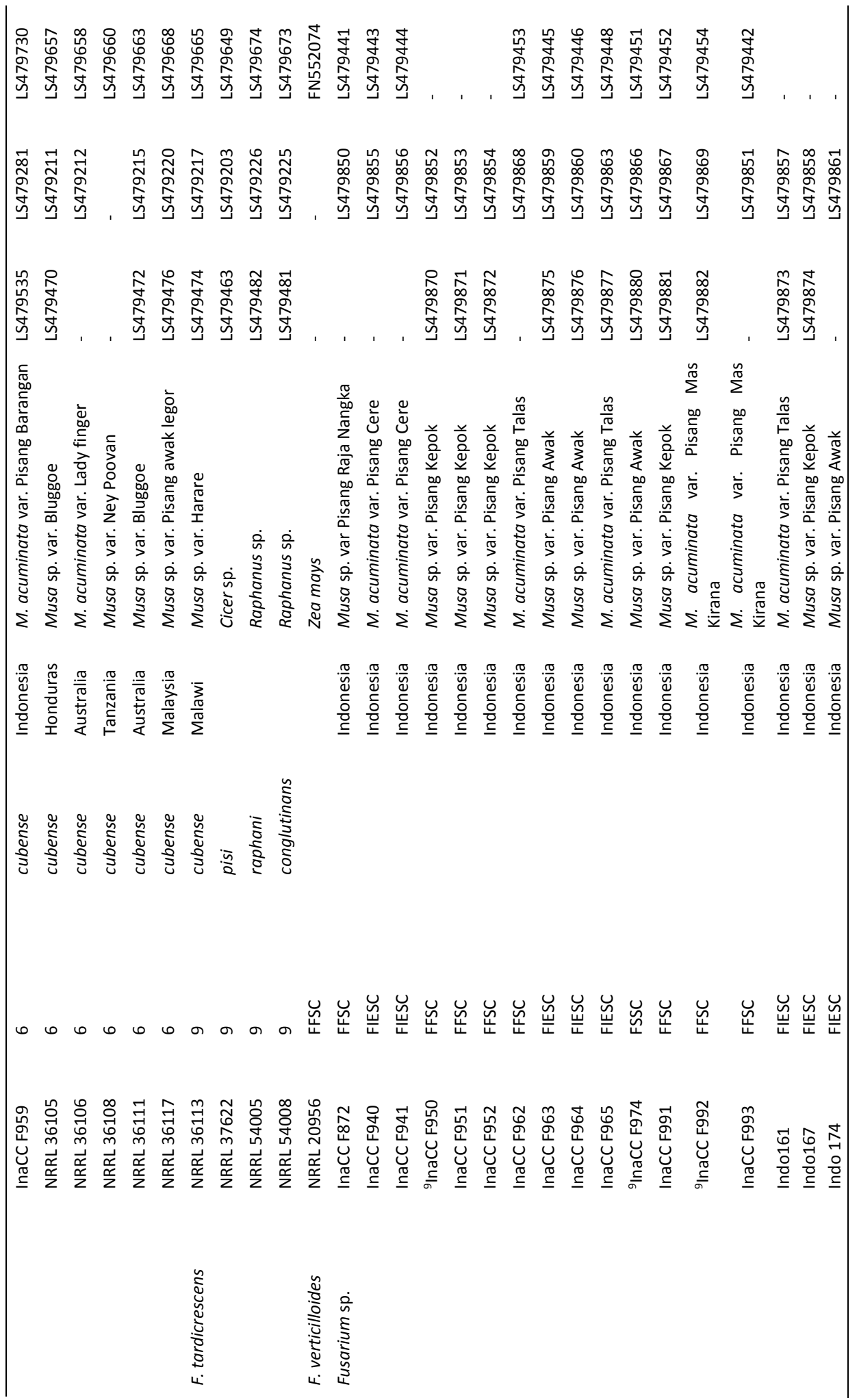




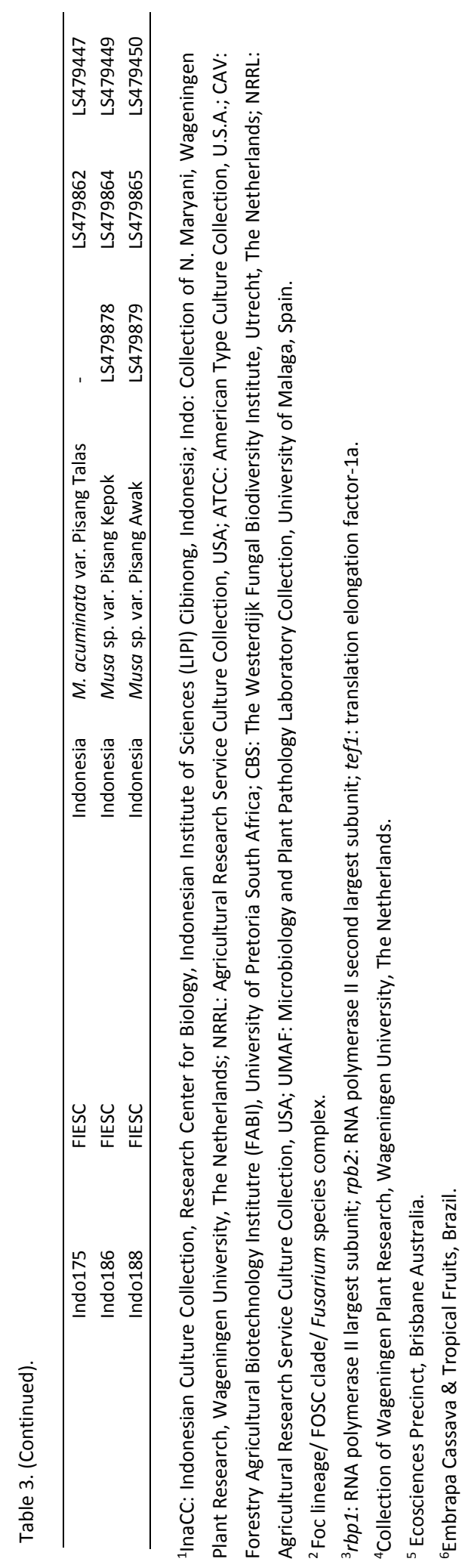




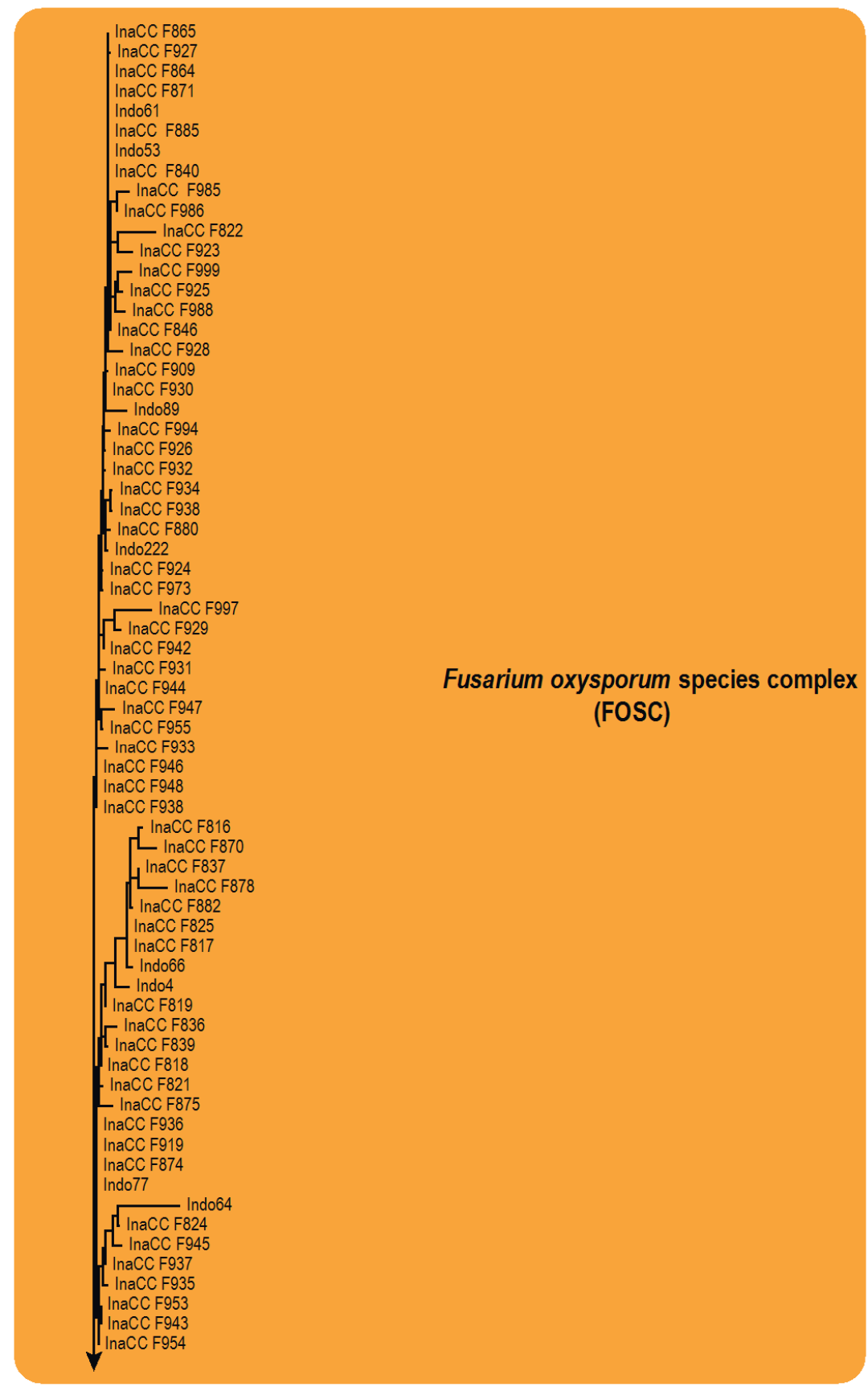

Fig. 4. Maximum likelihood tree inferred from the combined $r p b 1, r p b 2$ and tef1 genes sequence data sets of 244 isolates. The bootstrap support values (BP) and Bayesian posterior probabilities (PP) are given at nodes. Coloured blocks indicate the various Fusarium species complexes included. The tree is rooted to Fusarium dimerum (NRRL 36140). 


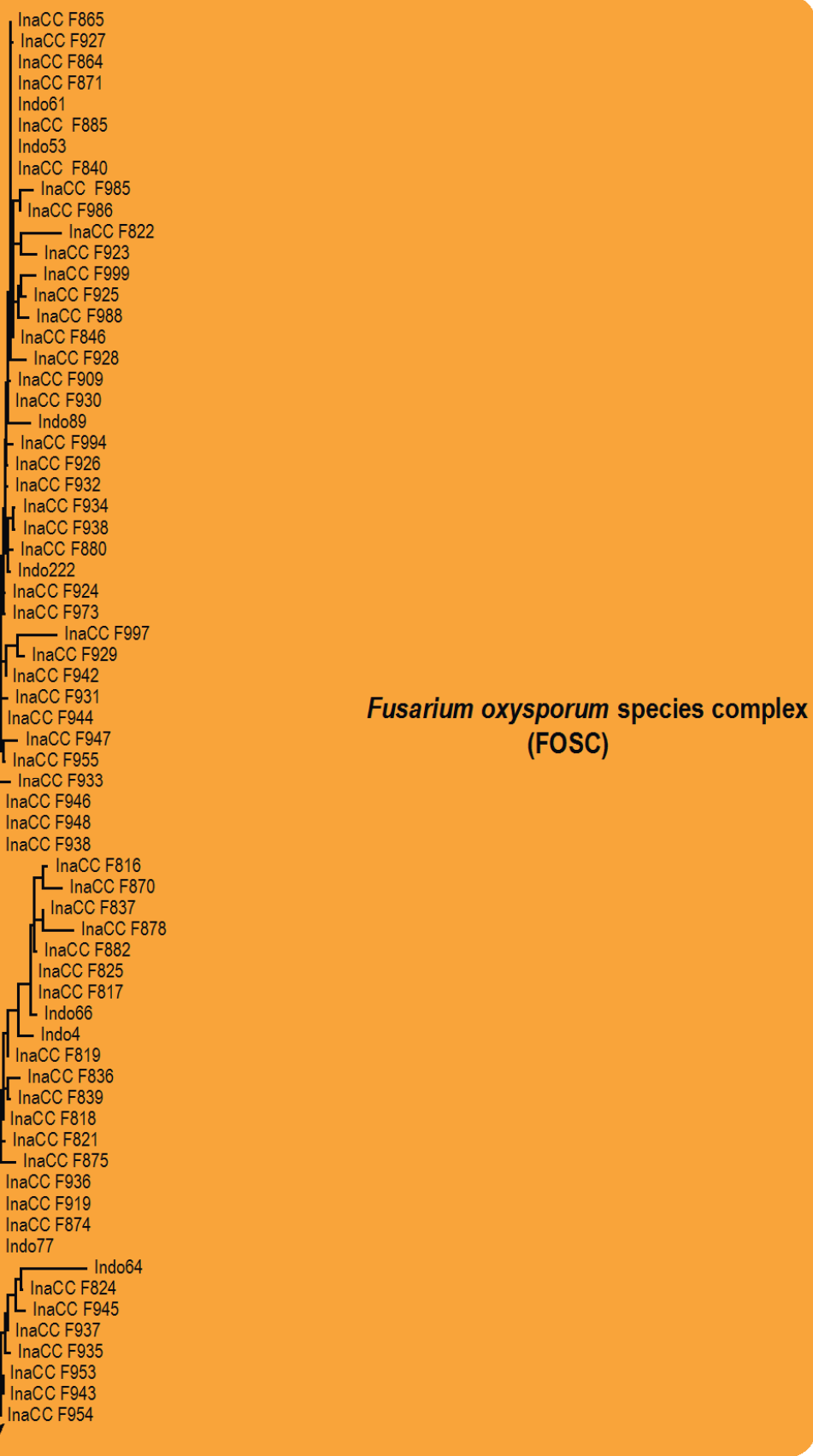

Fig. 4. (Continued). 


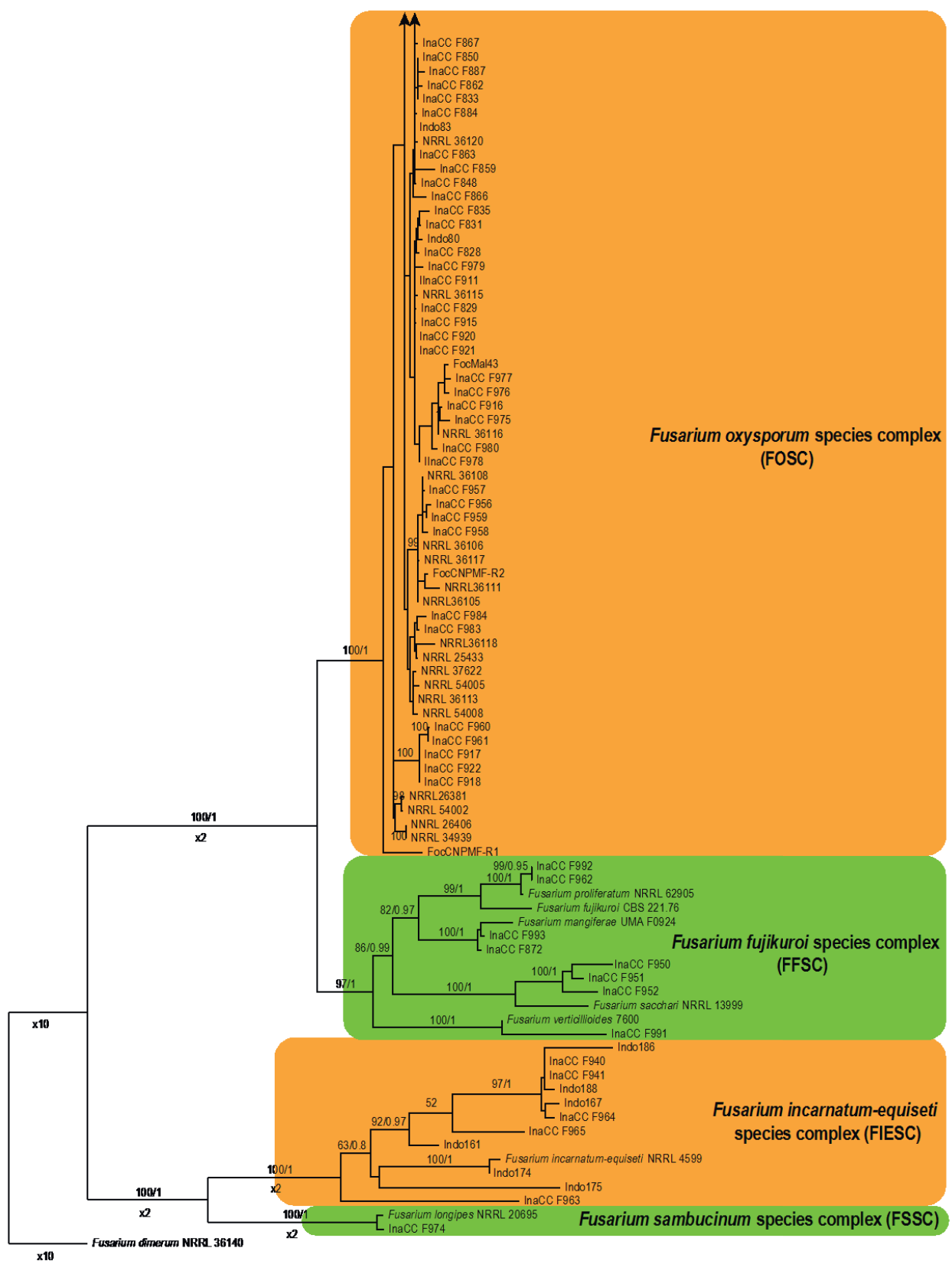

0.04

Fig. 4. (Continued). 


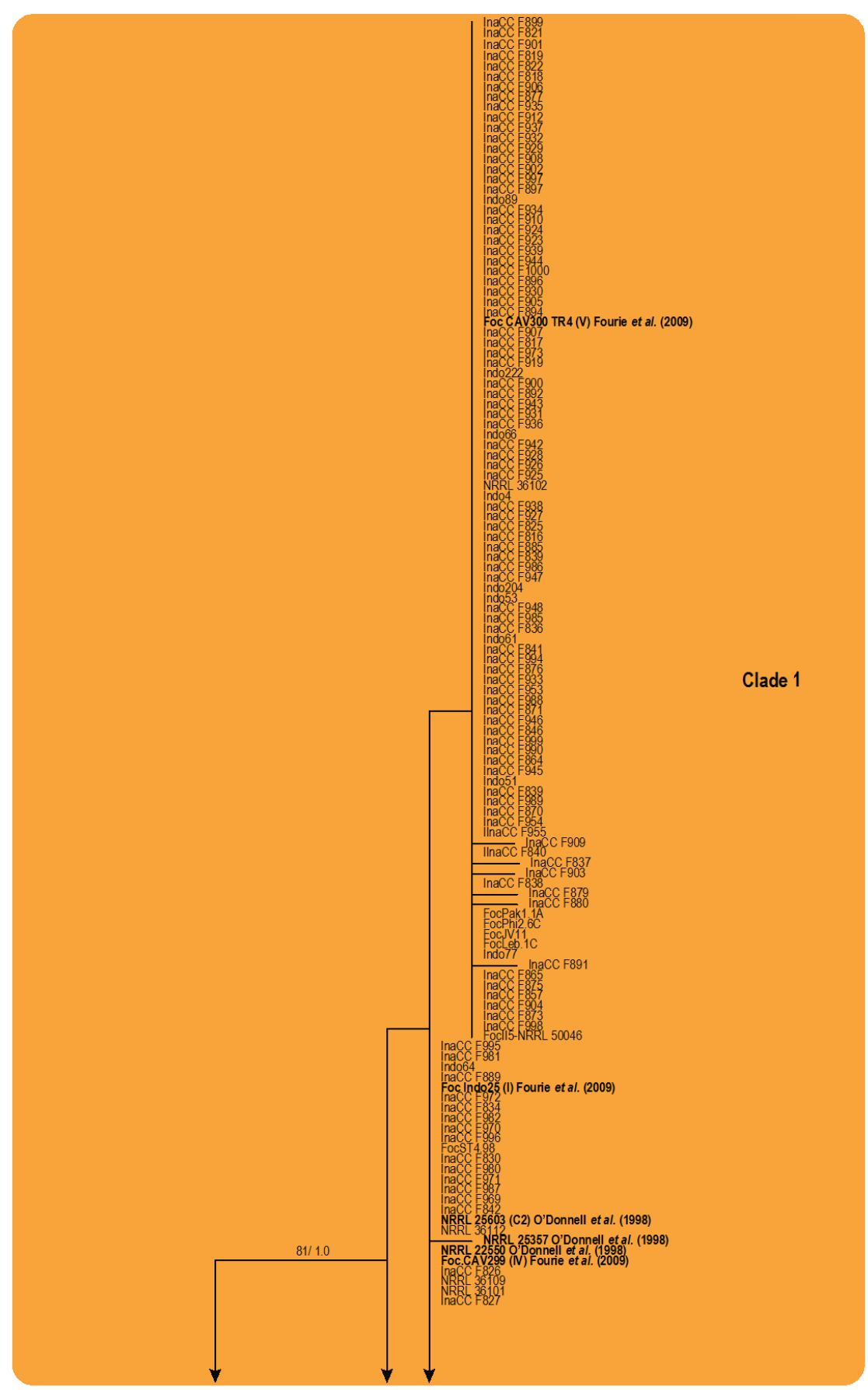

Fig. 5. Maximum likelihood tree inferred from the tef1 gene sequence data set of 183 Indonesian isolates in the FOSC clade. Included are representatives of the studies by O'Donnell et al. $(1998,2004)$ and Fourie et al. $(2009)$, indicated in bold. The bootstrap support values $>70 \%$ (BS) and Bayesian posterior probabilities $>0.95$ (PP) are given at nodes. The tree is rooted to Fusarium fujikuroi (CBS 221.76). 


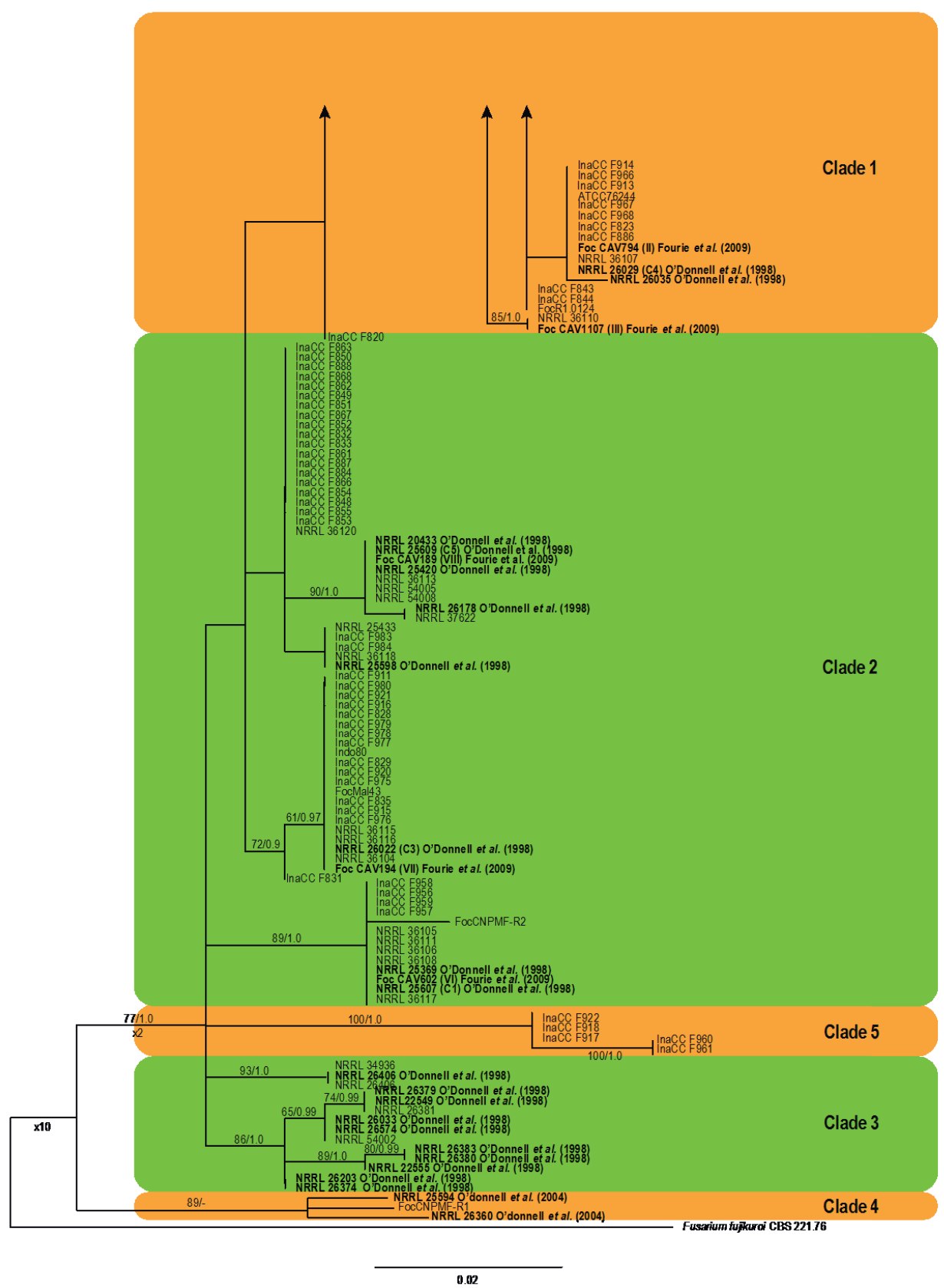

Fig. 5. (Continued). 


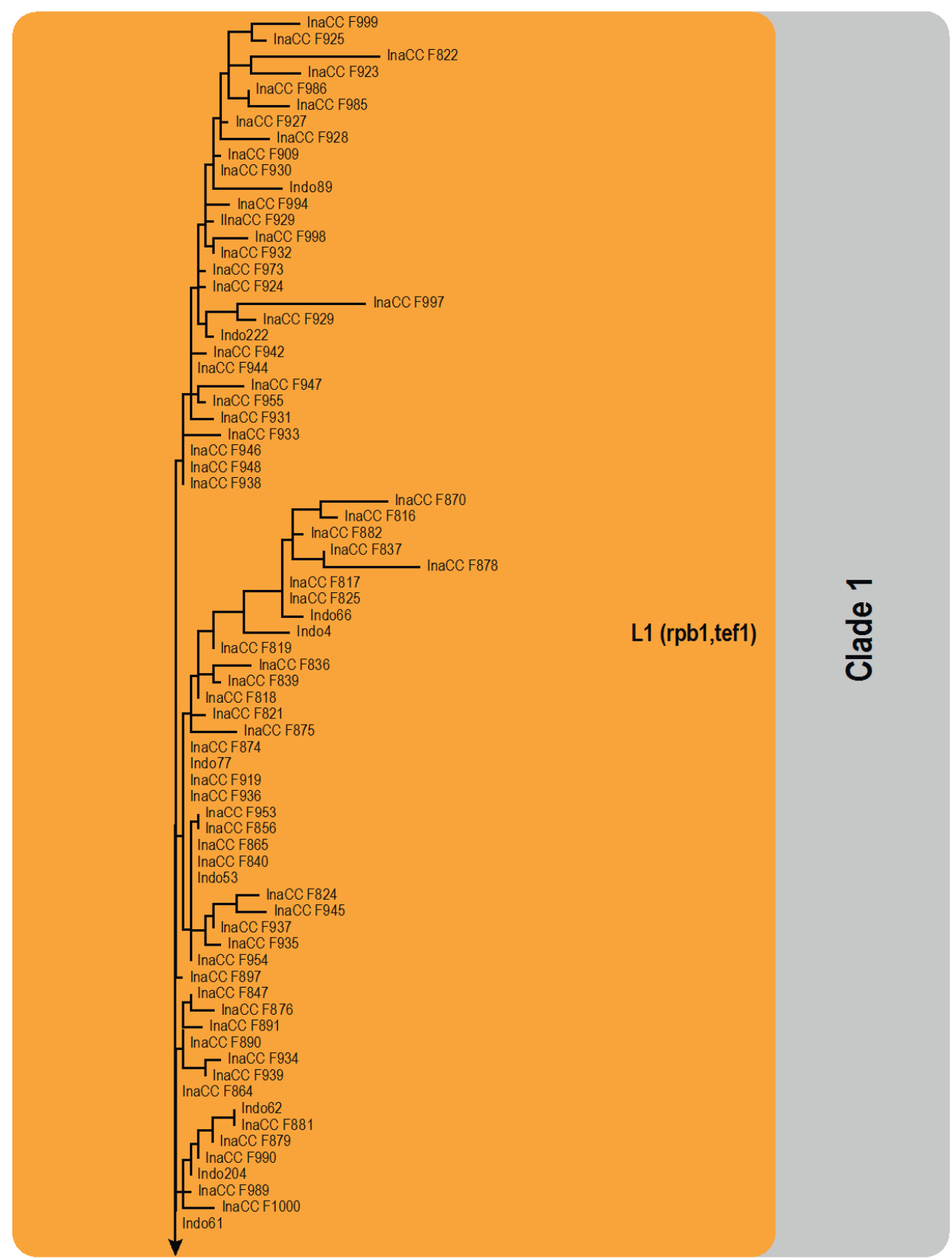

Fig. 6. Maximum likelihood tree inferred from the combined $r p b 1, r p b 2$ and tef1 genes sequence data sets. The bootstrap support values $>70 \%$ (BS) and Bayesian posterior probabilities $>0.95$ (PP) are given at nodes. Foc lineages are numbered based on the consensus from single and combined gene data sets represented by the coloured blocks. The tree is rooted to Fusarium fujikuroi (CBS 221.76). 


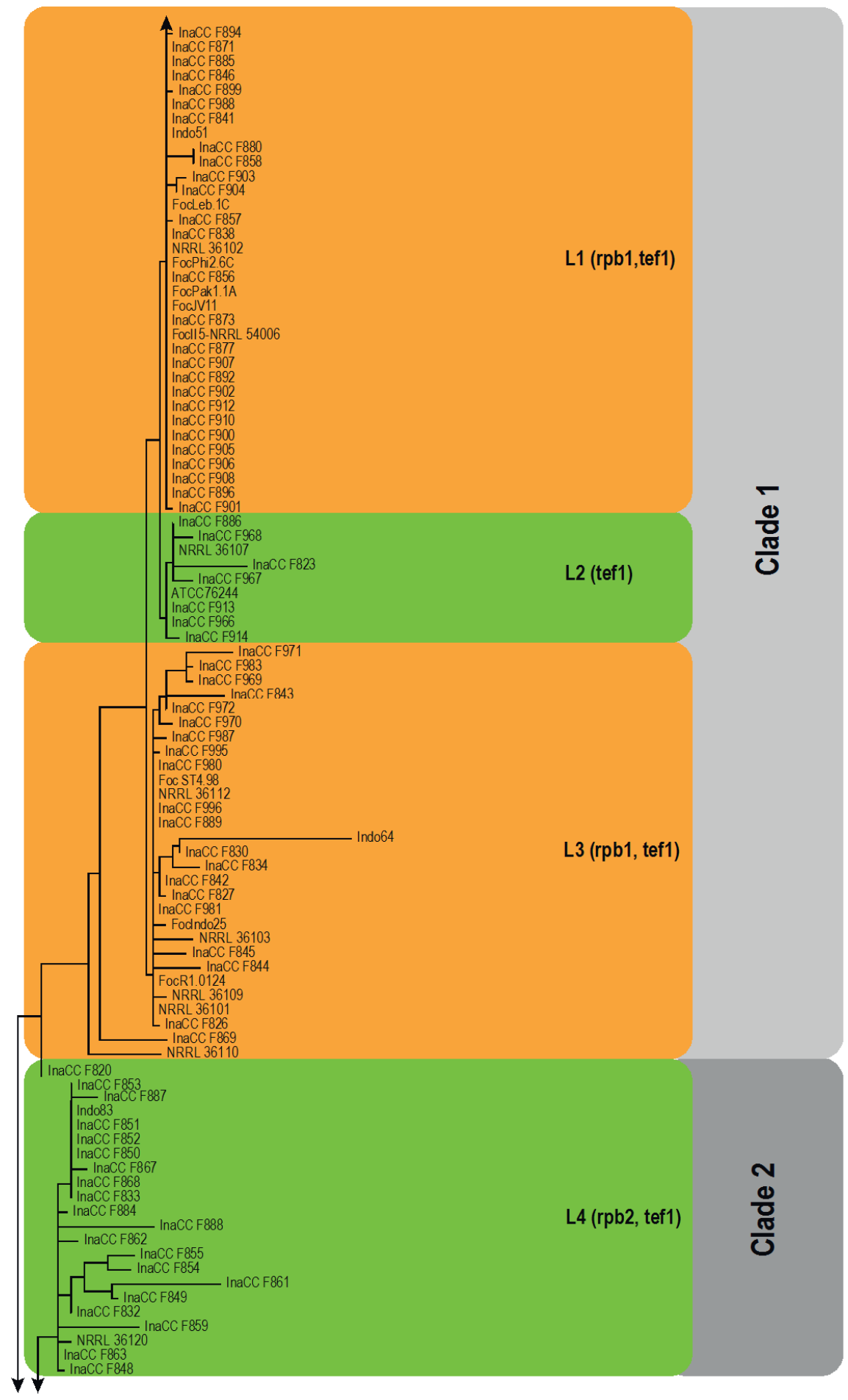

Fig. 6. (Continued). 


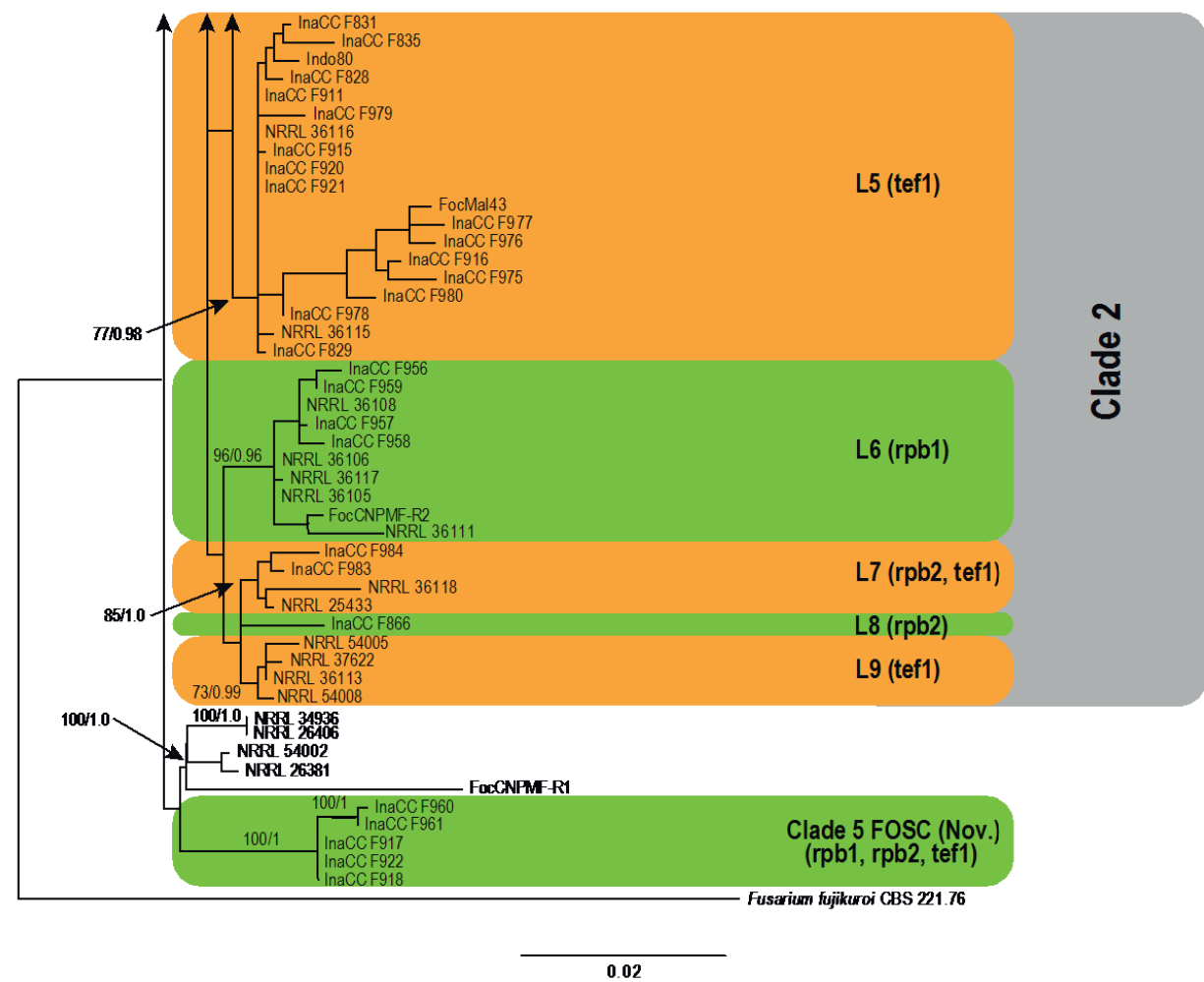

Fig. 6. (Continued).

Culture characteristics: Colony on PDA showing optimal growth at $25^{\circ} \mathrm{C}$ with an average growth rate of $4.5-5.0 \mathrm{~mm} / \mathrm{d}$. Colony reverse, uniformly white and unpigmented. Colony surface dry, cottony, white, with filamentous margin. No exudates observed. Aerial mycelium abundant, cottony, with abundant sporulation. Sporodochia formed abundantly on CLA after $7 \mathrm{~d}$, pale orange.

Geography and host: Kutai Timur, East Kalimantan, Musa sp. var. Pisang Kepok (ABB).

Pathogenicity: Pathogen on Gros Michel (AAA) and Cavendish (AAA).

Material examined: Indonesia, Kampung Salak Martadinata, Kutai Timur, East Kalimantan (117 $26^{\prime} 850^{\prime \prime} \mathrm{E}$ and $\left.0^{\circ} 11^{\prime} 590 \prime N\right)$, on infected pseudostem of Musa sp. var. Pisang Kepok (ABB), 16 Jun. 2014, N. Maryani, (holotype preserved as metabolically inactive culture, InaCC F822). 

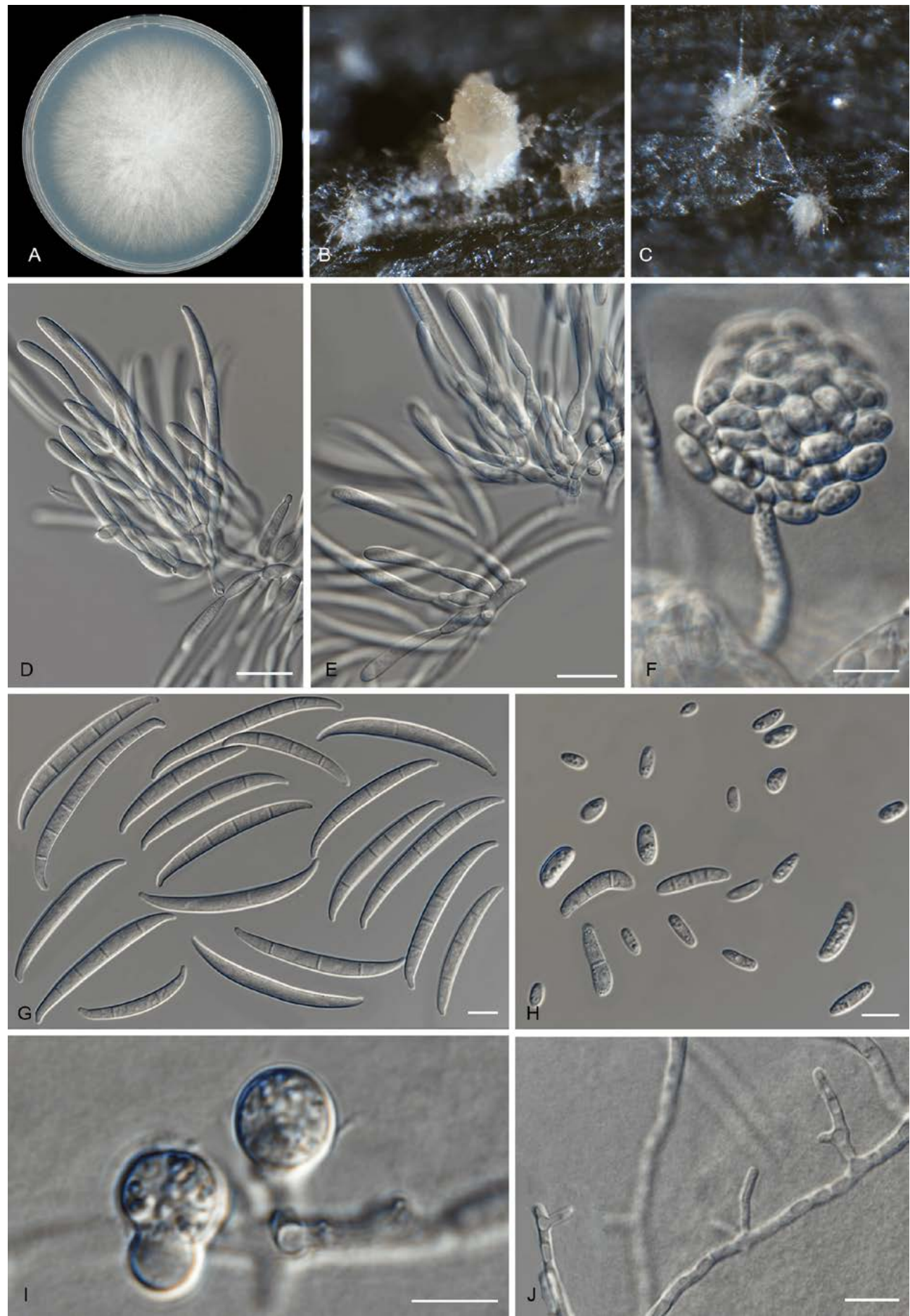

Fig. 7. Fusarium odoratissimum (InaCC F817). A. Culture grown on PDA. B-C. Sporodochia on carnation leaves D-E. Sporodochial branched conidiophores with monophialides. F. False head. G. Falcate-shaped macroconidia. H. Microconidia. I. Chlamydospores. J. Polyphialides. Scale bars D-J $=10 \mu \mathrm{m}$. 

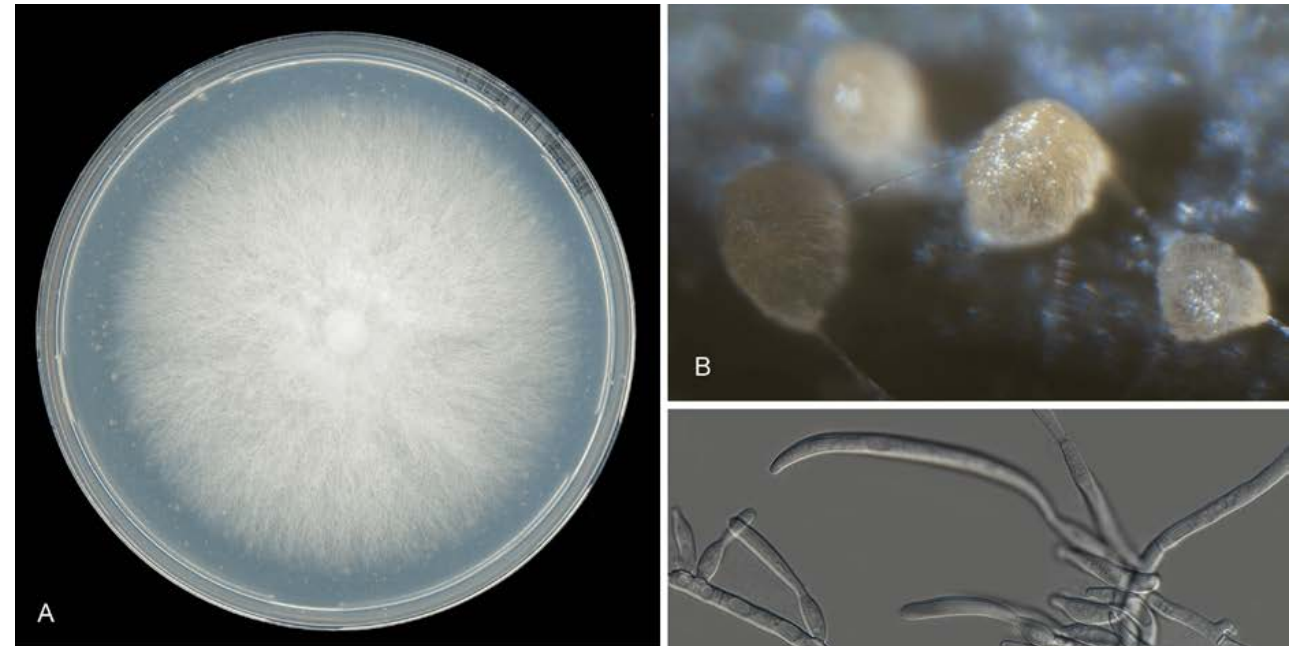

B
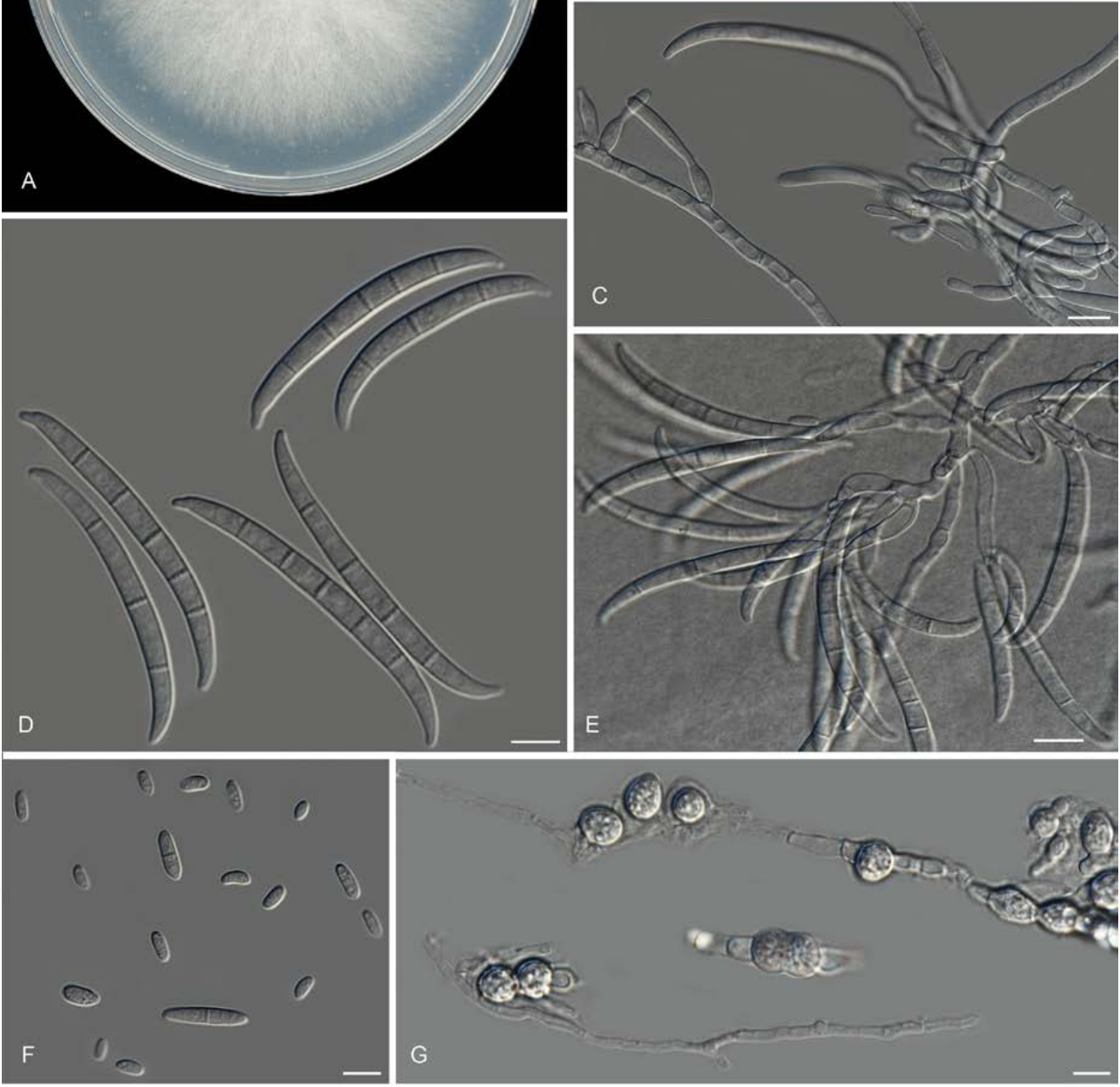

Fig. 8. Fusarium odoratissimum typed species (ex-type InaCC 822). A. Culture grown on PDA. B. Sporodochia on carnation leaves. C. Monophialides with initial conidia being formed. D. Falcate-shaped macroconida. E. Branched conidophores. F. Eliptical microconidia. G. Thick-walled chlamydospores. Scale bars $C-G=10 \mu \mathrm{m}$.

Notes: Fusarium odoratissimum formed a small cryptic clade within the L1 cluster (Fig. 6), and can be distinguished by the septation of its macroconidia (0-6-septate) and microconidia (03-septate), characteristics not common for F. oxysporum (Leslie \& Summerell 2006). This 
species also produces chlamydospores relatively more rapidly than was observed for other Fusarium isolates examined in this study. F. odoratissimum and all isolates in L1 produce a strong peculiarly stale odour in mature cultures, of which the causal volatiles remain to be characterised. Pathogenicity tests showed that $F$. odoratissimum and all isolates in lineage 1 were able to infect Cavendish and Gros Michel bananas. Isolates in this lineage were thus classified as TR4.

\section{Foc Lineage L2}

Fusarium purpurascens N. Maryani, L. Lombard, Kema \& Crous, sp. nov. MycoBank MB 826801. Fig. 9

Etymology: Name reflects the purple pigmentation which was observed when cultivated on potato dextrose agar.

Macroconidia abundant on CLA, less abundant on PDA and SNA, formed on sporodochia on CLA and on aerial conidiophores on SNA and PDA, falcate (50-)55-63(-67) $\times(4-) 6-7(-9) \mu \mathrm{m}$ (av. $59 \times 7 \mu \mathrm{m}$ ), 3-5-septate, with apical cells papillate, basal cells foot-shaped. Conidiogenous cells mono- or polyphialidic on sporodochia, or formed directly from hyphae (lateral phialides), 5-45 $\times$ 3-8 $\mu \mathrm{m}$. Microconidia abundant on PDA and SNA, less frequent on CLA, ovoid to ellipsoid, (8-)18(-37) × (3-)5(-6) $\mu \mathrm{m}$ (av. $12 \times 4 \mu \mathrm{m}$ ), 0-1-septate, arranged in false heads on branched conidiophores carried on hyphae. Aerial conidiophores rare on CLA and SNA, and formed abundantly on PDA, branched sparsely or formed laterally. Chlamydospores not observed.

Culture characteristics: Colony on PDA showing optimal growth at $25{ }^{\circ} \mathrm{C}$ with an average growth rate of $4.4-4.8 \mathrm{~mm} / \mathrm{d}$. Colony reverse, livid purple. Colony surface dry, cottony, white, filamentous in the centre and livid purple towards the margin, forming exudate droplets. Aerial mycelium abundant, cottony, with moderate sporulation. Sporodochia formed abundantly on CLA after $7 \mathrm{~d}$, pale orange.

Geography and host: Kutai Timur, East Kalimantan, Musa sp. var. Pisang Kepok (ABB).

Pathogenicity: Pathogen on Gros Michel (AAA).

Material examined: Indonesia, Kampung Salak Martadinata, Kutai Timur, East Kalimantan $\left(117^{\circ} 26^{\prime} 684^{\prime \prime} \mathrm{E}\right.$, $0^{\circ} 26^{\prime} 684^{\prime \prime} \mathrm{N}$ ), on infected pseudostem of Musa sp. var. Pisang Kepok (ABB), 17 Jun. 2014, N. Maryani, (holotype preserved as metabolically inactive culture, InaCC F886). 

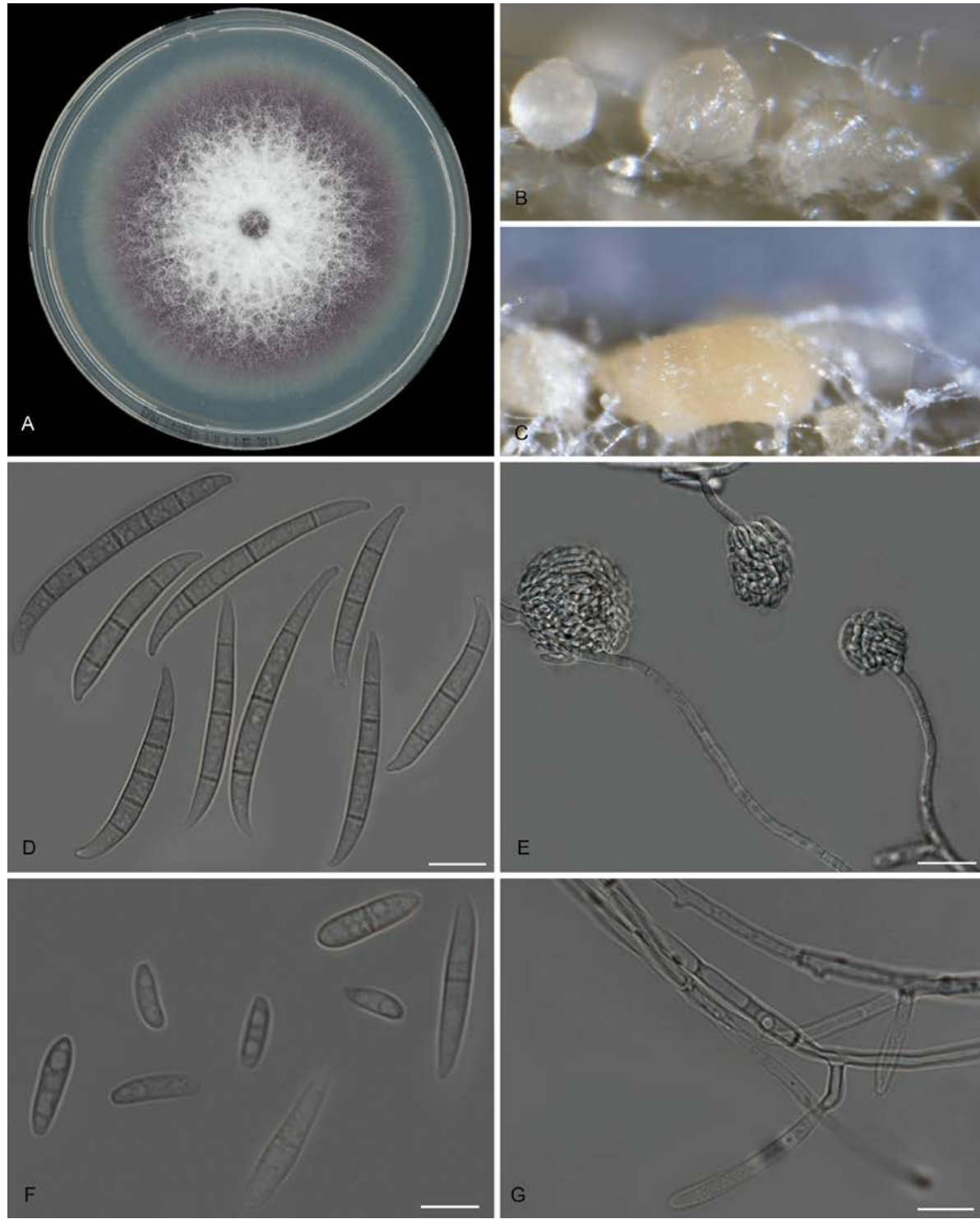

Fig. 9. Fusarium purpurascens (ex-type InaCC F886). A. Culture grown on PDA. B-C. Sporodochia grown on carnation leaves. D. Falcate-shaped macroconidia. E. False head. F. Microconidia. G. Monophialides. Scale bars $\mathrm{D}-\mathrm{G}=10 \mu \mathrm{m}$.

Notes: Fusarium pupurascens exhibits the strongest purple colony colour on PDA of all the isolates with purple colonies. It is relatively slow-growing compared to other isolates clustered in lineage L1. No chlamydospores were observed for this species, in contrast to other L1 members, which readily produce chlamydospores in culture. Furthermore, F. purpurascens produces exudate droplets, something not observed among other L1 isolates. Older cultures 
become pigmented, a distinctive phenomenon rarely seen in L1. F. purpurascens and other isolates in this lineage were able to infect Gros Michel, and were therefore classified as Race1.

\section{Foc Lineage L3}

Fusarium phialophorum N. Maryani, L. Lombard, Kema \& Crous, sp. nov. MycoBank MB826802. Fig. 10.

Etymology: Name refers to its elongated phialidic collarettes observed in culture.

Macroconidia abundant on CLA, less abundant on PDA and SNA, formed on sporodochia on CLA and on aerial conidiophores on SNA and PDA, falcate, (50-)54-60(-62) $\times(3-) 4-5(-7) \mu \mathrm{m}$ (av. $57 \times 7 \mu \mathrm{m}$ ), 2-5-septate, with apical cells papillate, basal cells foot-shaped. Conidiogenous cells monophialidic on sporodochia, or formed directly from hyphae (lateral phialides) with elongated collarettes, 7-41 × 3-7 $\mu \mathrm{m}$. Microconidia abundant on PDA, less frequent on CLA, ovoid to ellipsoid, (6-)7-16(-24) ×(3-)4(-6) $\mu \mathrm{m}$ (av. $12 \times 5 \mu \mathrm{m}), 0-1$-septate, arranged in false heads on branched or lateral conidiophores carried on hyphae. Aerial conidiophores rare on CLA and SNA and formed abundantly on PDA, branched sparsely or forming short lateral conidiophores. Chlamydospores globose to subglobose, formed terminally, single or in pairs, $(8-) 9-12(-13) \times(9-) 10(-11) \mu \mathrm{m}$, rarely produced on SNA after $7 \mathrm{~d}$, rough-walled.

Culture characteristics: Colony on PDA showing optimal growth at $25{ }^{\circ} \mathrm{C}$ with an average growth rate of 4.9-5.2 mm/d. Colony reverse, uniformly white and unpigmented. Colony surface dry, cottony, white, filamentous margin. No exudates observed. Aerial mycelium abundant, cottony, with high sporulation. Sporodochia formed abundantly on CLA after $7 \mathrm{~d}$, pale orange to orange.

Geography and host: Tanah Bumbu, South Kalimantan, Musa sp. var. Pisang Awak (ABB).

Pathogenicity: Pathogen on Gros Michel (AAA).

Materials examined: Indonesia, Kampung Betung, Tanah Bumbu, South Kalimantan (115 $\left.37^{\prime} 477^{\prime \prime} \mathrm{E}, 3^{\circ} 37^{\prime} 45^{\prime \prime} \mathrm{S}\right)$, on infected pseudostem of Musa sp. var. Pisang Awak (ABB), 20 Jun. 2014, N. Maryani, (holotype preserved as metabolically inactive culture, InaCC F971).

Notes: Fusarium phialophorum has elongated phialidic collarettes, which are rarely found in other lineages. Polyphialidic conidiophores were not found, and chlamydospores were formed, but were rare. Isolates in this lineage were able to infect Gros Michel but not Cavendish, and were therefore classified as Race1. 

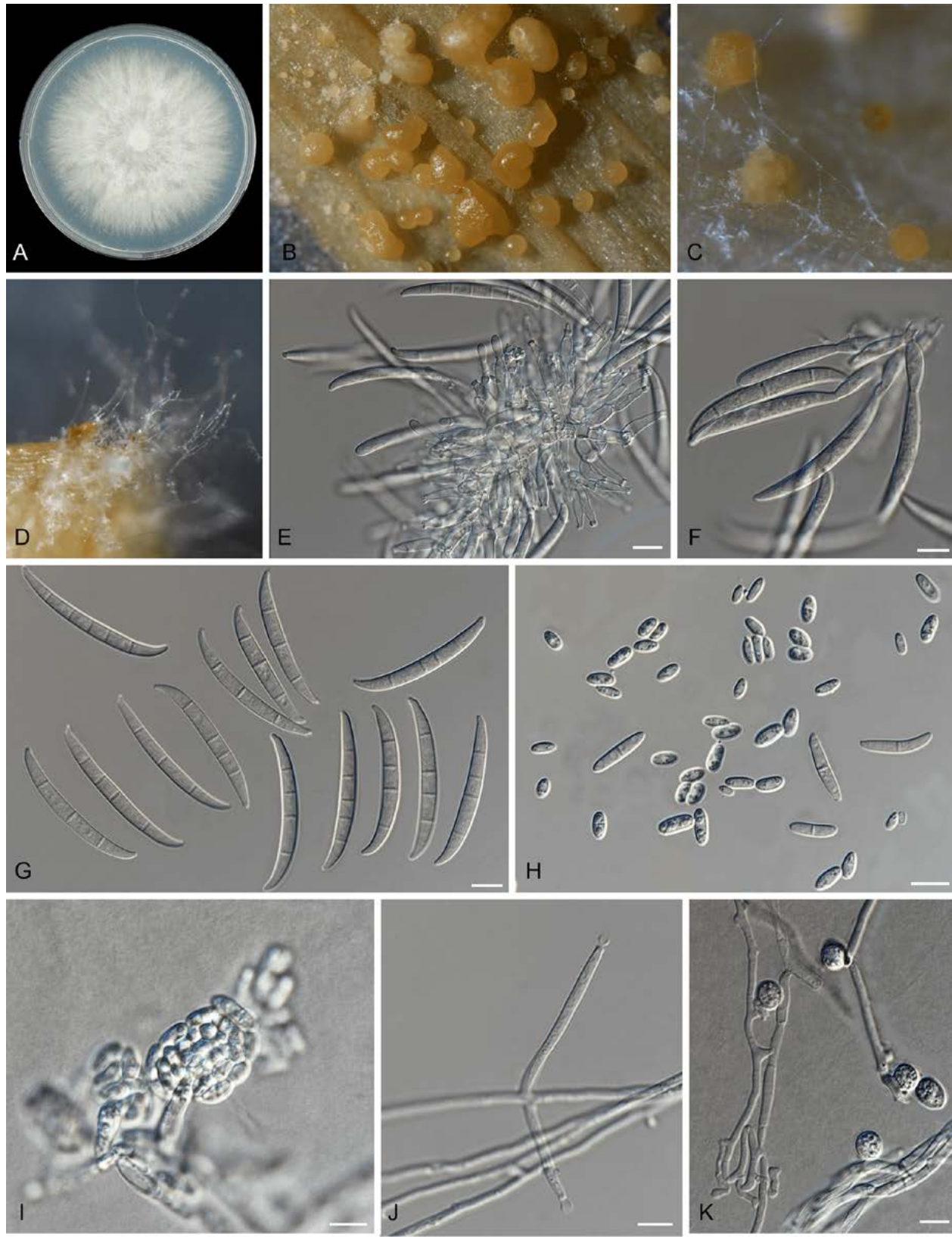

Fig. 10. Fusarium phialophorum (ex-type InaCC 971) . A. Culture grown on PDA. B-C. Sporodochia on carnation leaves. D. Aerial conidiophore on carnation leaves. E-F. Sporodochial phialides. G. Falcate-shaped macroconidia. H. Microconidia. I. False head. J. Lateral monophialides with long collaretes. K. Thick-walled chlamydospores. Scale bars $\mathrm{E}-\mathrm{K}=10 \mu \mathrm{m}$. 


\section{Foc Lineage L4}

Fusarium grosmichelii N. Maryani, L. Lombard, Kema \& Crous, sp. nov. MycoBank MB 826803. Fig. 11.

Etymology: Name reflects its association with the banana variety Gros Michel.

Macroconidia abundant on CLA, less abundant on PDA and SNA, formed on sporodochia on CLA and on aerial conidiophores on SNA and PDA, falcate, (47-)51-59(-64) $\times(5-) 6-8(-9) \mu \mathrm{m}$ (av. $55 \times 7 \mu \mathrm{m}$ ), 3-5-septate, with apical cells papillate, basal cells foot-shaped. Conidiogenous cells mono- or polyphialidic on sporodochia, on branched conidiophores, or formed directly from hyphae (lateral phialides), (8-)16-28(-36) × (3-)4-6(-7) $\mu \mathrm{m}$. Microconidia abundant on PDA and SNA, less frequent on CLA, ovoid to ellipsoid, (4-)9-17(-21) $\times(3-) 4-6(-7) \mu \mathrm{m}$ (av. 12 $\times 5 \mu \mathrm{m}), 0-1$-septate, arranged in false heads on branched or lateral conidiophores carried on hyphae. Chlamydospores globose to subglobose, formed terminally or intercalarily, single or in clumps, rarely produced on SNA after $7 \mathrm{~d}$, rough-walled.

Culture characteristics: Colony on PDA showing optimal growth at $25{ }^{\circ} \mathrm{C}$ with an average growth rate of $4.7-5.0 \mathrm{~mm} / \mathrm{d}$. Colony reverse in the dark uniformly white and unpigmented. Colony surface dry, cottony white with filamentous margin. No exudates observed. Aerial mycelium abundant, cottony, with abundant sporulation. Sporodochia formed abundantly on CLA after $7 \mathrm{~d}$, pale orange to orange.

Geography and host: Bogor, West Java, Musa acuminata var. Pisang Ambon Lumut (AAA).

Pathogenicity: Pathogen on Gros Michel (AAA).

Materials examined: Indonesia, Suakarya Megamendung, Bogor, West Java $\left(106^{\circ} 54^{\prime} 214^{\prime \prime} \mathrm{E}, 6^{\circ} 41^{\prime} 185^{\prime \prime} \mathrm{N}\right)$, on infected pseudostem Musa acuminata var. Pisang Ambon Lumut (AAA), 10 Jul. 2014, N. Maryani, (holotype preserved as metabolically inactive culture InaCC F833); ibid., Indo18.

Notes: Fusarium grosmichelii is morphologically very similar to F. phialophorum, but differs in having a higher number of septa in its macroconidia (3-5-septate). F. grosmichelii and others in this lineage are morphologically similar to $F$. odoratissimum, but $F$. grosmichelii was not able to infect Cavendish. Most of the isolates in L4 were tested on Gros Michel, and were able to cause disease, and were thus classified as Race1. 

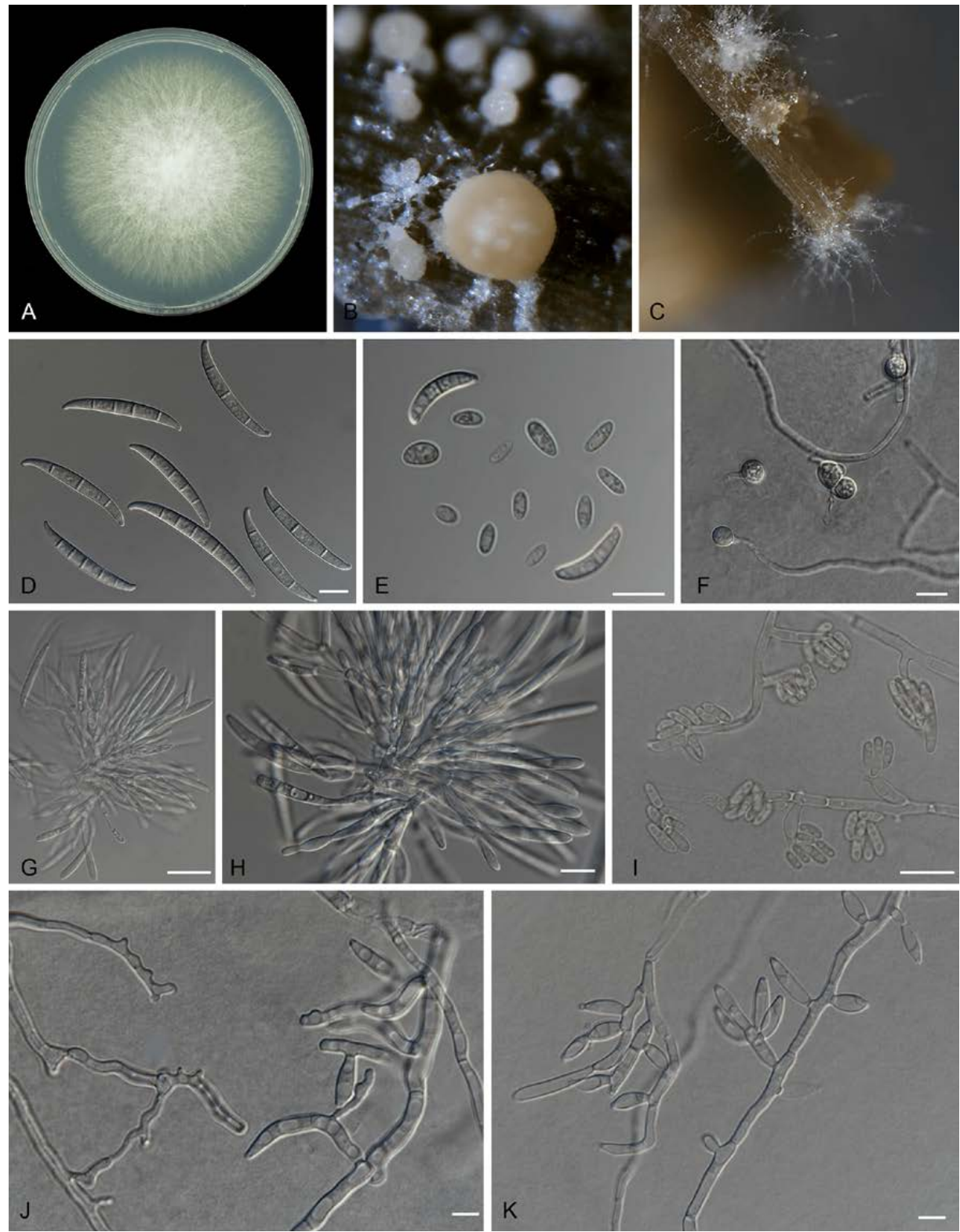

Fig. 11. Fusarium grosmichelii (ex-type InaCC 833). A. Culture grown on PDA. B. Sporodochia on carnation leaves. C. Aerial conidiophores from stereo microscope. D. Falcate-shaped macroconidia. E. Microconidia. F. Chlamydospores. G-H. Sporodochial phialides. I. False head. J. Polyphialides. K. Branched conidiophore. Scale bars $\mathrm{D}-\mathrm{F}, \mathrm{H}-\mathrm{K}=10 \mu \mathrm{m}, \mathrm{G}=20 \mu \mathrm{m}$. 


\section{Foc Lineage L5}

Fusarium duoseptatum N. Maryani, L. Lombard, Kema \& Crous, sp. nov. MycoBank MB826804. Fig. 12.

Etymology: Name reflects the fact that its microconidia are frequently 2-septate.

Macroconidia abundant on CLA, less abundant on PDA and SNA, formed on sporodochia on CLA and on aerial conidiophores on SNA and PDA, falcate, (50-)53-63(-68) $\times(5-) 6-8(-9) \mu \mathrm{m}$ (av. $58 \times 7 \mu \mathrm{m}$ ), 3-5-septate, with apical cells papillate, basal cells foot-shaped. Conidiogenous cells mono- or polyphialidic on sporodochia, or on aerial hyphae, or formed directly from hyphae as lateral phialides, (5-)9-25(-38) $\times(3-) 4-7(-9) \mu \mathrm{m}$. Microconidia abundant on PDA and SNA, less frequent on CLA, ovoid to ellipsoid, (9-)21(-33) $\times(2-) 3(-6) \mu \mathrm{m}$ (av. $15 \times 5 \mu \mathrm{m}$ ), $0-2$-septate, arranged in false heads on branched conidiophores carried on hyphae. Aerial conidiophores rare on CLA and SNA, formed abundantly on PDA, branched sparsely or formed laterally. Chlamydospores globose to subglobose, formed laterally, intercalary or terminally, single or in pairs, $(6-) 8-10(-11) \times(6-) 7-9(-11) \mu \mathrm{m}$, abundantly produced on SNA after $7 \mathrm{~d}$, rough-walled.

Culture characteristics: Colony on PDA showing optimal growth at $25^{\circ} \mathrm{C}$ with an average growth rate of $3.8-4.1 \mathrm{~mm} / \mathrm{d}$. Colony reverse violet, mycelium becoming purple, and pigmented with age. Colony surface dry, cottony violet in the centre, and white towards the margin. No exudates observed. Aerial mycelium abundant, cottony, with moderate sporulation. Sporodochia formed abundantly on CLA after $7 \mathrm{~d}$, pale orange to orange.

Geographic and host: Kapuas, Central Kalimantan, Musa sp. var. Pisang Kepok (ABB).

Pathogenicity: Pathogen on Gros Michel (AAA).

Material examined: Indonesia, Serapat tengah, Kapuas Timur, Central Kalimantan $\left(114^{\circ} 28^{\prime} 65^{\prime \prime} \mathrm{E}, 3^{\circ} 6^{\prime} 9^{\prime \prime} \mathrm{S}\right)$, on infected pseudostem of Musa sp. var. Pisang Kepok (ABB), 22 Jun. 2014, N. Maryani, (holotype preserved as metabolically inactive culture InaCC F916).

Notes: Fusarium duoseptatum has distinctive septation in its microconidia, being 0-2-septate, thus differing from F. gromichelii, which is $0-1$-septate. The former is relatively slow-growing compared to members of the most closely related lineage, $L 4$, and forms pigmentation in the centre of colony that is not observed in isolates of L4. F. duoseptatum and most of the members of $L 5$ were able to infect Gros Michel, and were therefore classified as Race1. 

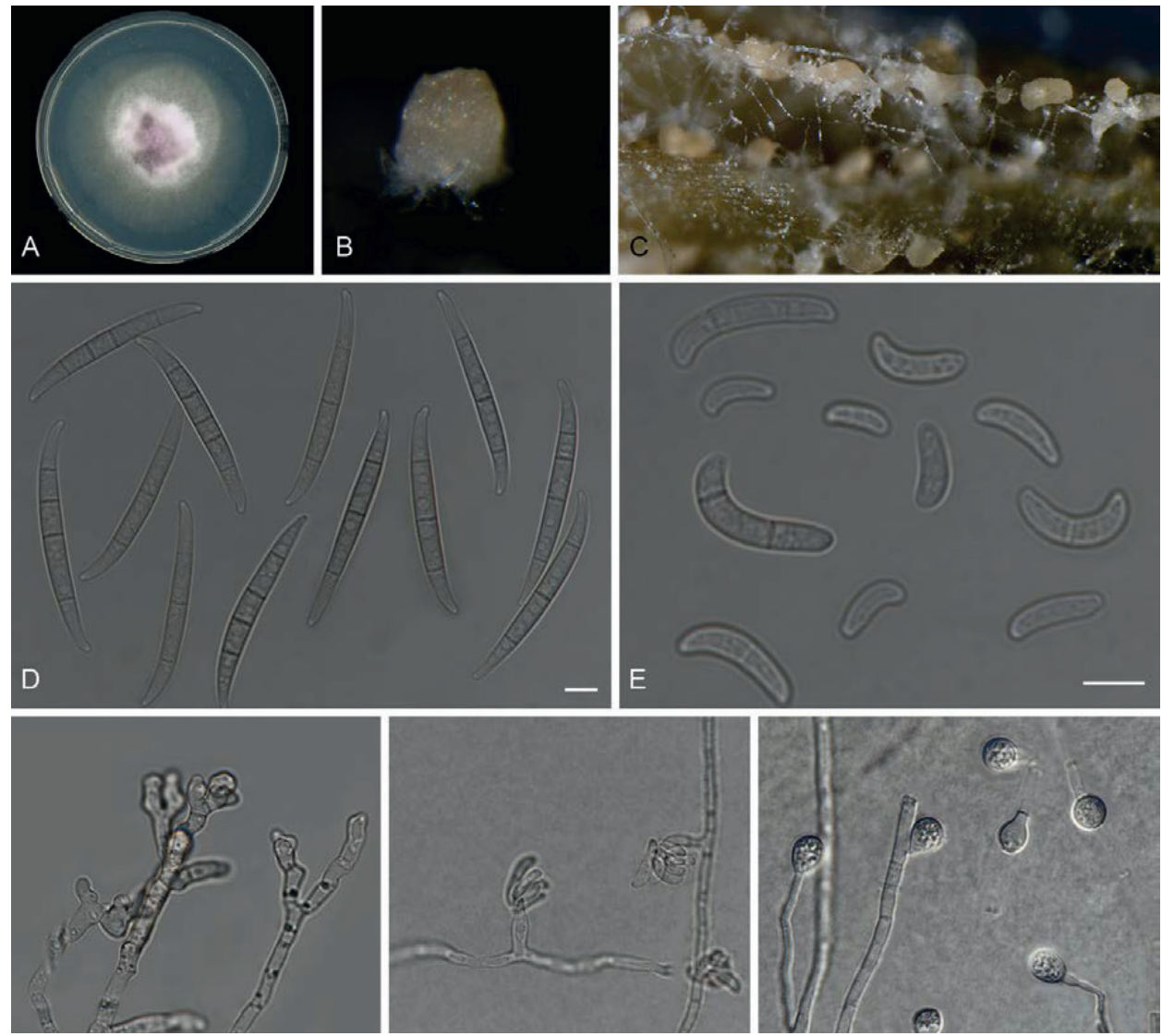

Fig. 12. Fusarium duoseptatum (ex-type InaCC 916). A. Culture grown on PDA. B-C. Sporodochia on carnation leaves. D. Falcate-shaped macroconidia. E. Microconidia. F. Polyphialidic conidiogenous cells. G. False head. H. Chlamydospores. Scale bars D-H=10 $\mu \mathrm{m}$.

\section{Foc Lineage $\mathbf{L 6}$}

Fusarium tardichlamydosporum N. Maryani, L. Lombard, Kema \& Crous, sp. nov. MycoBank MB826805. Fig. 13.

Etymology: Name reflects the delayed chlamydospore production observed in this species.

Macroconidia abundant on CLA, less abundant on PDA and SNA, formed on sporodochia on CLA and on aerial conidiophores on SNA and PDA, falcate, (36-)37-43(-45) $\times(4-) 5-6(-7) \mu \mathrm{m}$ (av. $40 \times 5 \mu \mathrm{m}$ ), 3-5-septate, with apical cells papillate, basal cells foot-shaped. Conidiogenous cells monophialidic on sporodochia, or on aerial hyphae, or formed directly on hyphae as lateral phialides, (3-)7-14(-19) $\times(2-) 3-5(-8) \mu \mathrm{m}$. Microconidia abundant on PDA and SNA, ovoid to ellipsoid, (3-)5-9(-15) × (2-)5(-9) $\mu \mathrm{m}$ (av. $7 \times 3 \mu \mathrm{m}$ ), 0-2-septate, arranged in false heads on branched conidiophores carried on hyphae. Aerial conidiophores rare on CLA and 
SNA and formed abundantly on PDA, branched sparsely or formed laterally. Chlamydospores abundantly produced after $4 \mathrm{wk}$, globose to subglobose, $(6-) 7-10(-13) \times(4-) 6-9(-10) \mu \mathrm{m}$, formed terminally or intercalarily, single or in pairs, rough-walled.

Culture characteristics: Colony on PDA showing optimal growth at $25{ }^{\circ} \mathrm{C}$ with an average growth rate of 4.6-5.6 mm/d. Colony reverse sparsely dark purple in the centre, becoming white towards the margins, and purple slate, pigmented with age. Colony surface dry, cottony, with white filamentous margin, and lacking exudates. Aerial mycelium abundant, cottony, with abundant sporulation. Sporodochia formed abundantly on CLA after $7 d$, pale orange to orange.

Geography and host: Sikka, Flores, Musa acuminata var. Pisang Barangan (AAA).

Pathogenicity: Pathogen on Gros Michel (AAA).

Materials examined: Indonesia, Desa Kota Uneng Kecamatan Alok, Sikka Flores, East Nusa Tenggara $\left(112^{\circ} 12^{\prime} 16^{\prime \prime} \mathrm{E}, 8^{\circ} 37^{\prime} 11^{\prime \prime} \mathrm{S}\right)$, on infected pseudostem of Musa acuminata var. Pisang Barangan (AAA), 21 Aug. 2015 , N. Maryani, (holotype preserved as metabolically inactive culture, InaCC F958).

Notes: Colonies of Fusarium tardichlamydosporum are relatively fast growing (av. 4.6-5.6 $\mathrm{mm} / \mathrm{d}$ ) compared to those of $F$. duoseptatum (av. 3.8-4.1 mm/d). Polyphialidic conidiophores were not observed in this species/lineage. Chlamydospores were produced, but only after 4 wk. F. tardichlamydosporum was able to infect Gros Michel, and is therefore classified as Race1.

\section{Foc Lineage $\mathrm{L7}$}

Fusarium cugenangense N. Maryani, L. Lombard, Kema \& Crous, sp. nov. MycoBank MB826807. Fig. 14.

Etymology: Name reflects Cugenang, the location where this species was collected in Indonesia.

Macroconidia abundant on CLA, formed on sporodochia, on aerial conidiophores or on lateral phialides, falcate, (44-)47-54(-57) × (5-)6-7(-8) $\mu \mathrm{m}$ (av. $53 \times 7 \mu \mathrm{m}), 3-6$-septate, with apical cells papillate, basal cells foot-shaped. Conidiogenous cells monophialidic on sporodochia, or on aerial hyphae, or formed directly from hyphae as lateral phialides, (5-)12-31(-45) × (3-)5$7(-8) \mu \mathrm{m}$. Microconidia abundant on PDA and SNA, less frequent on CLA, ovoid to ellipsoid, $(7-) 8-11(-24) \times(2-) 7(-12) \mu \mathrm{m}$ (av. $12 \times 5 \mu \mathrm{m}), 0-3$-septate, arranged in false heads on 
branched conidiophores carried on hyphae. Aerial conidiophores rare on CLA and SNA, and formed abundantly on PDA, branched sparsely or formed laterally. Chlamydospores rarely produced on SNA after $4 \mathrm{wk}$, globose to subglobose, $(9-) 10-14(-16) \times(10-) 11-14(-16) \mu \mathrm{m}$, formed terminally, single or in pairs, rough-walled.

Culture characteristics: Colony on PDA showing optimal growth at $25{ }^{\circ} \mathrm{C}$ with an average growth rate of 5.2-5.4 mm/d. Colony reverse purple at centre to pale viscous grey, white towards the margins, becoming purple slate with age, and pigmented. Colony surface dry, cottony, dark purple to white with filamentous margin, lacking exudates. Aerial mycelium abundant, cottony, with profuse sporulation. Sporodochia formed abundantly on CLA after 7 $d$, pale orange to orange.

Geography and host: Cianjur, West Java, Musa sp. var. Pisang Kepok (ABB).

Pathogenicity: Non-pathogenic on Gros Michel (AAA) and Cavendish (AAA).

Material examined: Indonesia, Cugenang, Cianjur, West Java $\left(107^{\circ} 4^{\prime} 109^{\prime \prime} \mathrm{E}, 6^{\circ} 47^{\prime} 867^{\prime \prime} \mathrm{S}\right)$, on infected pseudostem Musa sp. var. Pisang Kepok (ABB), 10 Jul. 2014, N. Maryani, (holotype preserved as metabolically inactive culture, InaCC F984).

Notes: Lineage 7, including Fusarium cugenangense and other isolates, represents an Indonesian lineage with isolates that are closely related to other formae speciales (Fig. 6; e.g. NRRL 25433 Fusarium oxysporum f. sp. vasinvectum). Polyphialidic conidiogenous cells were not observed in this species. This species has macroconidia with unique septation (3-6septate) and microconidia (0-3-septate), which is rather uncommon for Fusarium oxysporum species. This species causes a slight infection on Cavendish and Gros Michel, and testing on other cultivars such as Bluggoe (Pisang Kepok, ABB) are needed to fully classify strains as FocRace2. 

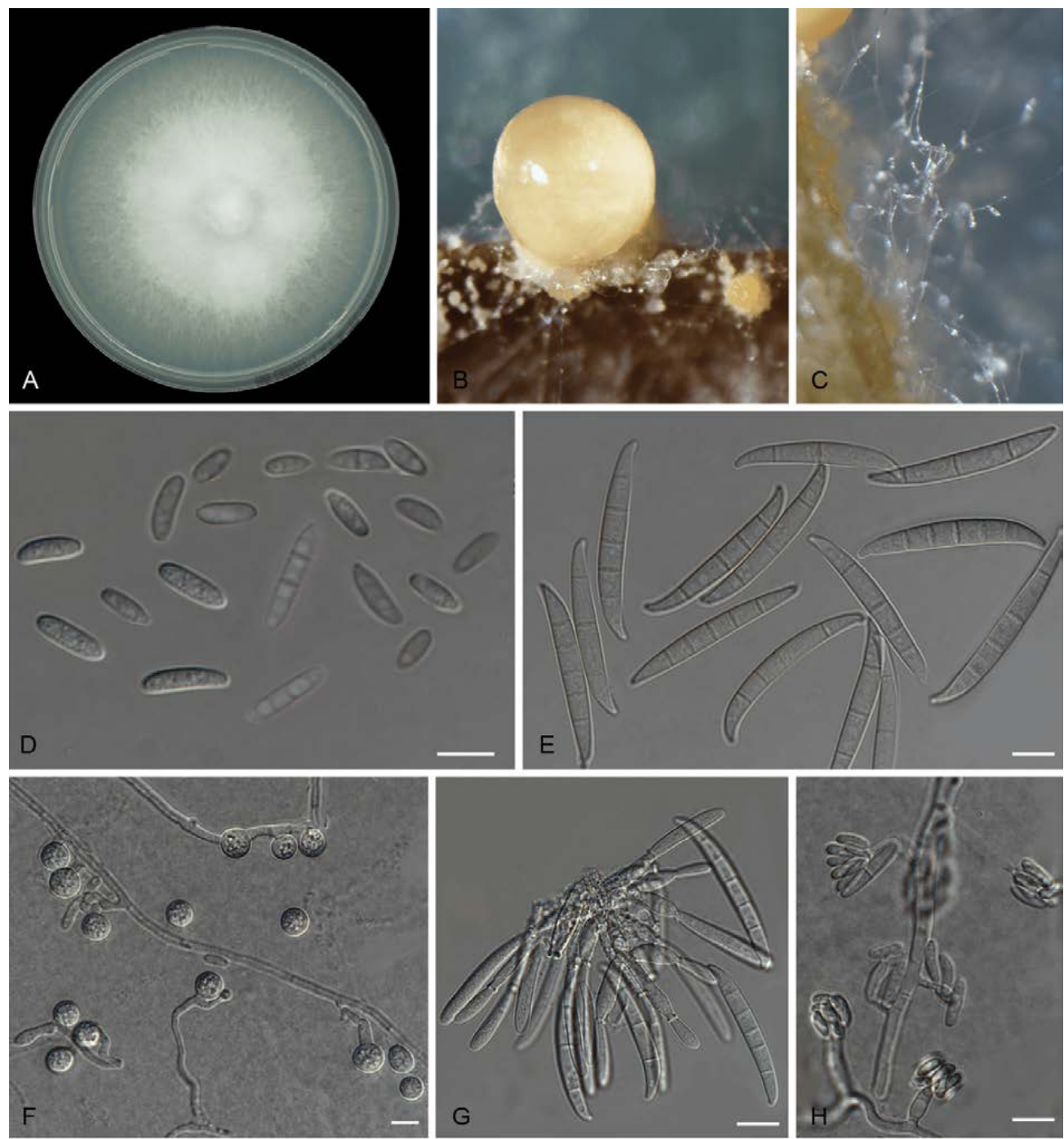

Fig. 13. Fusarium tardichlamydosporum (ex-type InaCC F958). A. Culture grown on PDA. B. Sporodochia on carnation leaves. C. Aerial conidiophore. D. Microconidia. E. Falcate-shaped macroconidia. F. Chlamydospores. G. Sporodochial phialides. H. False head. Scale bars $\mathrm{D}-\mathrm{H}=10 \mu \mathrm{m}$.

\section{Foc Lineage $\mathrm{L} 8$}

Fusarium hexaseptatum N. Maryani, L. Lombard, Kema \& Crous, sp. nov. MycoBank MB826808. Fig. 15.

Etymology: Name reflects the six conidial septa observed in its macroconidia.

Macroconidia abundant on CLA, less so on PDA and SNA, formed on sporodochia on CLA and on aerial conidiophores on SNA and PDA, falcate, (34-)45-71(-76) $\times(5-) 6-8(-9) \mu \mathrm{m}(\mathrm{av} .58 \times$ 
$7 \mu \mathrm{m})$, 3-6-septate, with apical cells papillate, basal cells foot-shaped. Conidiogenous cells mono- or polyphialidic on sporodochia, or formed directly from on hyphae (lateral phialides), 7-20 $\times$ 2-6 $\mu \mathrm{m}$. Microconidia abundant on PDA and SNA, rare on CLA, ovoid to ellipsoid, (4) $8-23(-29) \times(2-) 7(-12) \mu \mathrm{m}$ (av. $16 \times 5 \mu \mathrm{m}), 0-1$-septate, arranged in false heads on branched conidiophores carried on hyphae. Aerial conidiophores rare on CLA and SNA and formed abundantly on PDA, branched sparsely or formed laterally. Chlamydospores abundantly formed in hyphae, globose to subglobose, $(5-) 14(-20) \times(4-) 6-12(-17) \mu \mathrm{m}$, formed terminally or intercalarily, single or in pairs.

Culture characteristics: Colony on PDA showing optimal growth at $25{ }^{\circ} \mathrm{C}$ with an average growth rate of 4.9-5.9 mm/d. Colony reverse, in the dark, white and becoming livid purple in the centre of the colony. Colony surface with filamentous margin, dry, cottony, white becoming livid vinaceous in age. No exudates observed. Aerial mycelium abundant, cottony, with high sporulation. Sporodochia formed abundantly on CLA after $7 \mathrm{~d}$, colourless to pale orange.

Geography and host: Sukabumi, West Java, Pisang Ambon Kuning (AAA).

Pathogenicity: Pathogen on Gros Michel (AAA).

Material examined: Indonesia, Parakan Lima, Sukabumi, West Java $\left(106^{\circ} 48^{\prime} 674^{\prime \prime} \mathrm{E}, 6^{\circ} 59^{\prime} 874^{\prime \prime} \mathrm{S}\right)$, on infected pseudostem Musa acuminata var. Pisang Ambon Kuning (AAA), 11 Jul. 2014, N. Maryani, (holotype preserved as metabolically inactive culture, InaCC F866).

Notes: Fusarium hexaseptatum is the single species in L8. Macroconidia with 6 septa are abundantly observed in this lineage, whereas in L7 and L9, they are very rare. This lineage is distinguished from L7 and L9 by its ability to cause disease on Gross Michel, and therefore it was classified as Race1. Fusarium hexaseptatum has chlamydospores that are relatively large compared to those in other lineages (av. $9 \times 9 \mu \mathrm{m}$ ). 

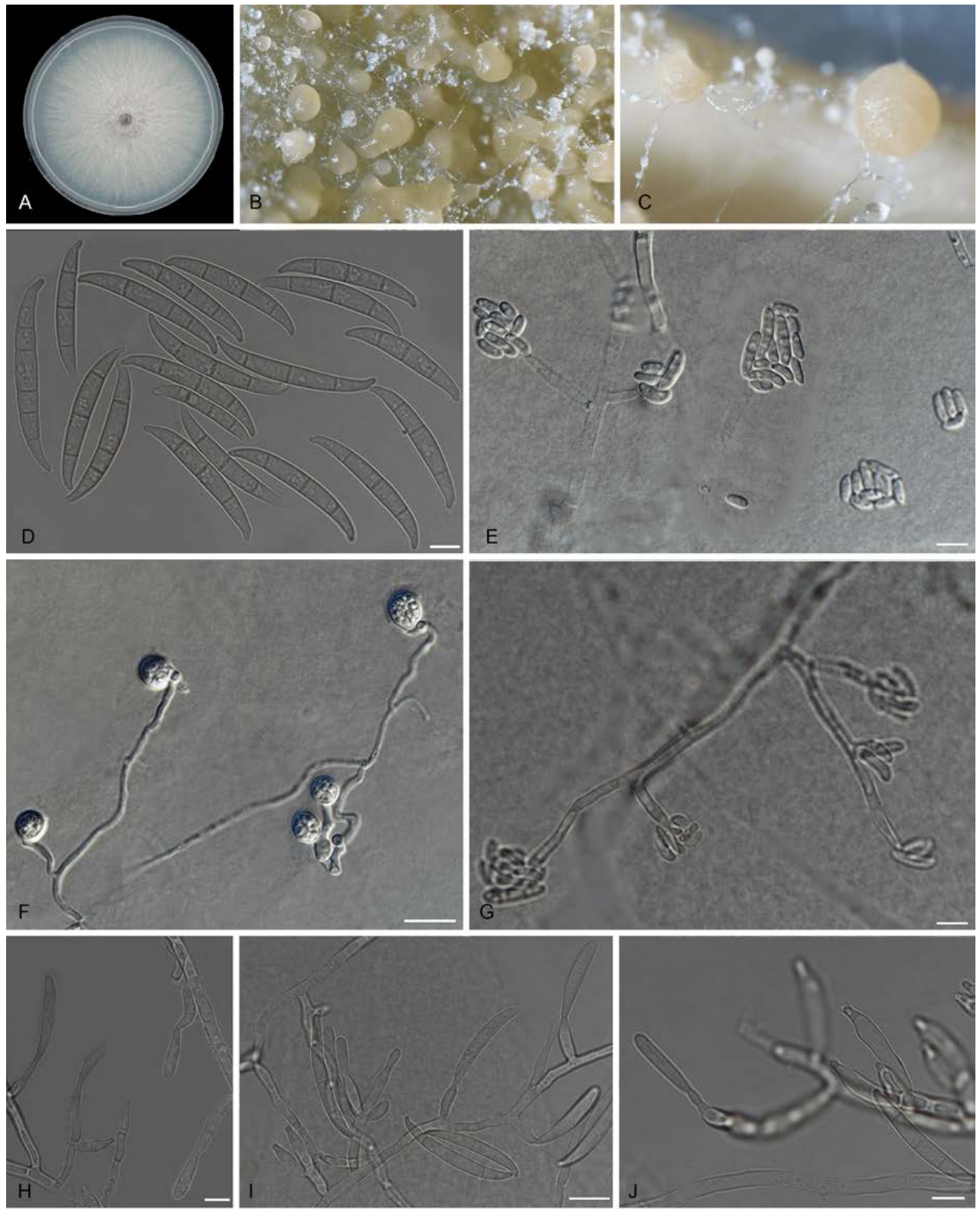

Fig. 14. Fusarium cugenangense (ex-type InaCC F984). A. Culture grown on PDA. B-C. Sporodochia on carnation leaves. D. Falcate-shaped macroconidia. E. Microconidia. F. Chlamydospores. G. False head. H. Monophialides conidiogenous cells. I-J. Branched conidiophores. Scale bars D-J=10 $\mu \mathrm{m}$. 

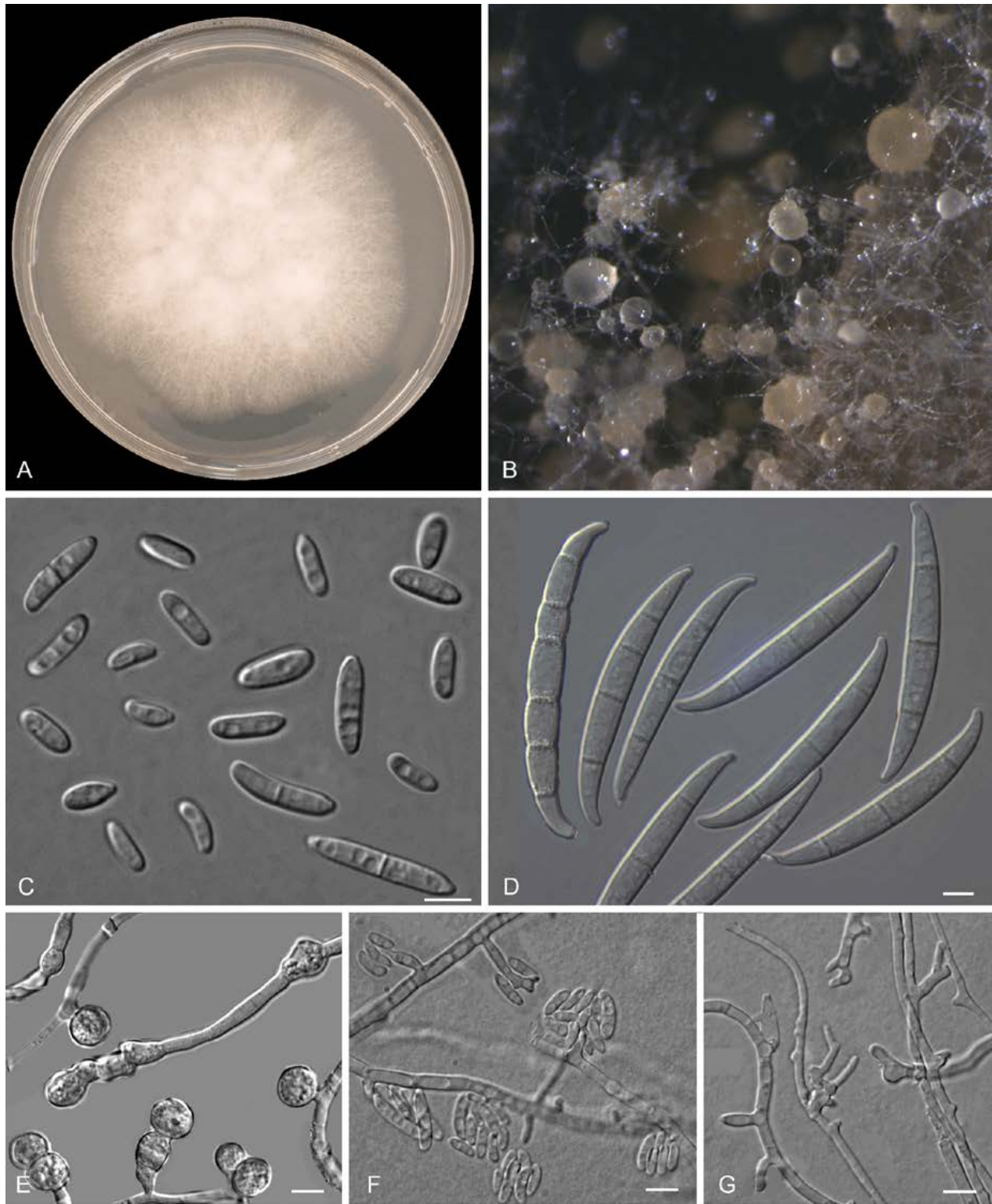

Fig. 15. Fusarium hexaseptatum (ex-type InaCC F866). A. Culture grown on PDA. B. Sporodochia on carnation leaves. C. Microconidia. D. Falcate-shaped macroconidia. E. Thick-walled chlamydospores. F. False head. G. Monophialides and polyphialides. Scale bars $\mathrm{C}-\mathrm{G}=10 \mu \mathrm{m}$. 


\section{Foc Lineage L9}

Fusarium tardicrescens N. Maryani, L. Lombard, Kema \& Crous, sp. nov. MycoBank MB826809. Fig. 16.

Etymology: Name reflects the slow growth rate in culture.

Macroconidia abundant on CLA and SNA, less abundant on PDA, formed on sporodochia on CLA and on aerial conidiophore on SNA and PDA, falcate, (52-)56-75(-89) $\times(5-) 6-8(-9) \mu \mathrm{m}$ (av. $66 \times 7 \mu \mathrm{m}$ ), 2-6-septate, with apical cells papillate, basal cells foot-shaped. Conidiogenous cells mono- and polyphialidic on sporodochia formed directly from hyphae (lateral phialides), 7-32 × 2-6 $\mu \mathrm{m}$. Microconidia abundant on PDA and SNA, less so on CLA, ovoid to ellipsoid, (7)10-16(-20) × (2)-5(-7) $\mu \mathrm{m}$ (av. $13 \times 4 \mu \mathrm{m}), 0-1$-septate, arranged in false heads on branched conidiophores carried on hyphae. Chlamydospores globose to subglobose, (5-)7-9(-10) $\times(5-$ )6-8(-10) $\mu \mathrm{m}$, formed intercalarily or terminally, singly or in pairs, produced abundantly on SNA after $7 \mathrm{~d}$, brown, rough-walled.

Culture characteristics: Colony on PDA showing optimal growth at $25{ }^{\circ} \mathrm{C}$ with an average growth rate of 2.9-3.9 mm/d. Colony reverse, in the dark, dark violet becoming dark livid and pigmented. Colony surface dry, cottony, dark purple becoming dark livid. No exudates observed. Aerial mycelium abundant, cottony, with abundant sporulation. Sporodochia formed abundantly on CLA after $7 d$, pale orange to orange.

Geography and host: NA.

Pathogenicity: NA.

Material examined: Malawi, Karonga, Misuku Hills, Musa sapientum cv. Harare, 1989, R.C. Ploetz NRRL 36113 (holotype preserved as metabolically inactive culture CBS 102024).

Notes: Fusarium tardicrescens in $\mathrm{L9}$ represents one of two lineages of formae specialis cubense, which clustered with other formae speciales. This lineage does not contain any Indonesian isolates. Fusarium tardicrescens is the slowest growing species (av. 2.9-3.9 mm/d). Fusarium tardicrescens causes moderate infection on both Cavendish and Gros Michel (Ordóñez 2018). 

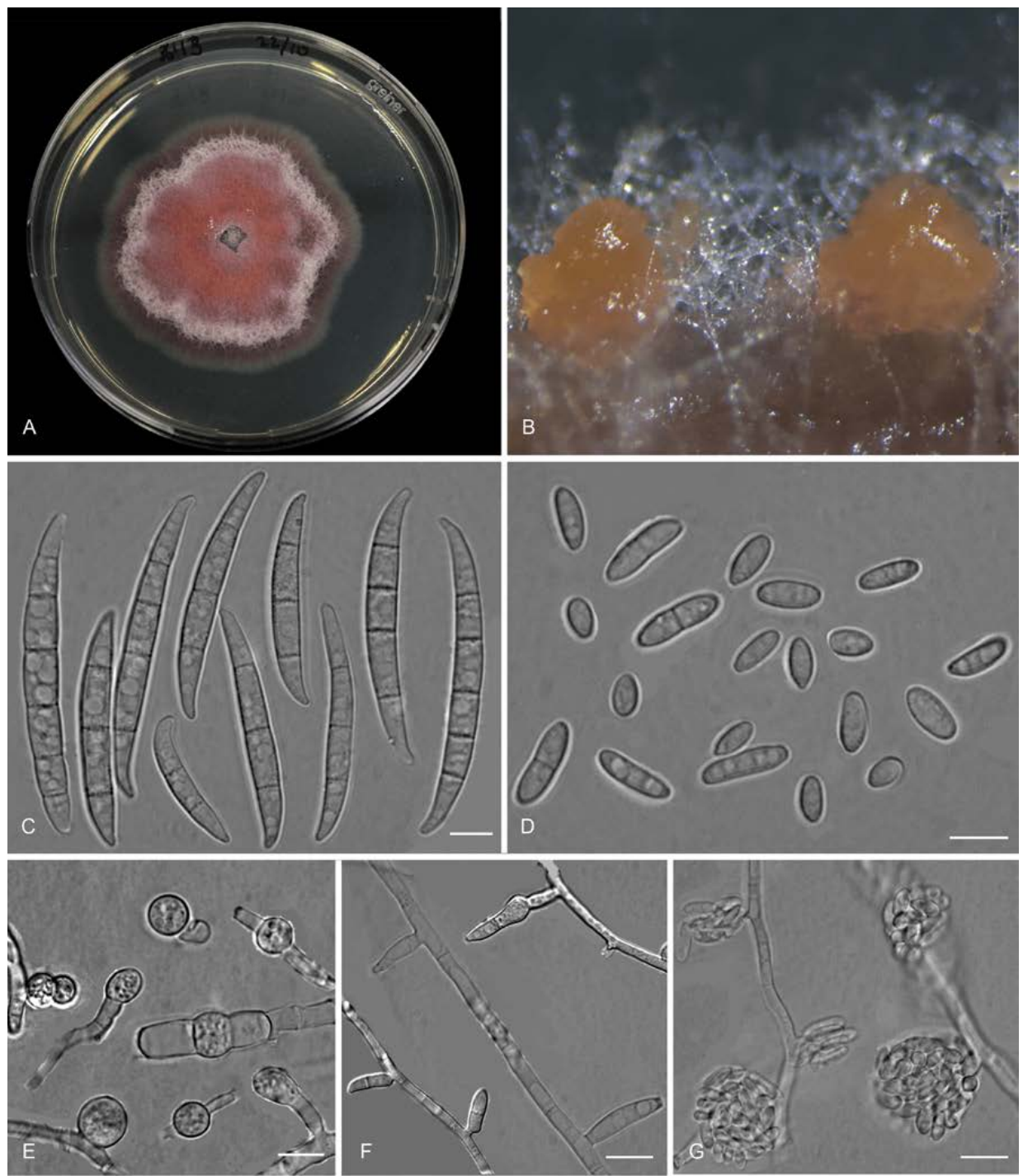

Fig. 16. Fusarium tardicrescens (ex-type CBS 102024). A. Culture grown on PDA. B. Sporodochia on carnation leaves. C. Falcate-shaped macroconidia. D. Microconidia. E. Thick-walled chlamydospores. F. Monophialides produce micro conidia and macroconidia. G. False head. Scale bars $\mathrm{C}-\mathrm{G}=10 \mu \mathrm{m}$.

\section{Novel Clade/ Taxa in FOSC}

Fusarium kalimantanense N. Maryani, L. Lombard, Kema \& Crous, sp. nov. MycoBank MB826810. Fig. 17.

Etymology: Name reflects Kalimantan, the island in Indonesia from where this fungus was collected. 
Macroconidia abundant on CLA, less abundant on PDA and SNA, formed on sporodochia on CLA and on aerial conidiophores on SNA and PDA, falcate, (52-)56-63(-65) $\times(5-) 6-7(-8) \mu \mathrm{m}$ (av. $59 \times 7 \mu \mathrm{m}$ ), 3-5-septate, with apical cells papillate, basal cells foot-shaped. Conidiogenous cells monophialidic on sporodochia, or on aerial hyphae, or formed directly from hyphae as lateral phialides, (9-)11-15(-16) $\times(2-) 3(-5) \mu \mathrm{m}$. Microconidia abundant on PDA and SNA, less frequent on CLA, ovoid to ellipsoid, (6-)8-15(-20) $\times(2-) 3-4(-7) \mu \mathrm{m}$ (av. $12 \times 4 \mu \mathrm{m}$ ), aseptate, arranged in false heads on branched conidiophores borne on hyphae. Aerial conidiophore sparse on CLA and SNA and formed abundantly on PDA, branched sparsely or formed laterally. Chlamydospores rarely produced on SNA after $7 \mathrm{~d}$, globose to subglobose, formed terminally or laterally, single or in pairs, $(6-) 7-10(-11) \times(7-) 8-9(-10) \mu \mathrm{m}$, rough-walled.

Culture characteristics: Colony on PDA showing optimal growth at $25{ }^{\circ} \mathrm{C}$ with an average growth rate of 4.8-1.2 mm/d. Colony reverse rosy buff (pinkish) to white towards the margins, becoming fuscous black and pigmented with age. Colony surface dry, cottony, rosy buff (pinkish) to white, becoming purplish grey with age, filamentous margin, and lacking exudates. Aerial mycelium abundant, cottony, with moderate sporulation. Sporodochia formed abundantly on CLA after $7 \mathrm{~d}$, pale orange to orange.

Geography and host: Katingan, Central Kalimantan, Musa acuminata var. Pisang Ambon (AAA).

Pathogenicity: Non-pathogenic on Gros Michel (AAA) and Cavendish (AAA).

Material examined: Indonesia, Pulau Malam, Katingan, Central Kalimantan $\left(113^{\circ} 13^{\prime} 333^{\prime \prime} \mathrm{E}, 1^{\circ} 36^{\prime} 374^{\prime \prime} \mathrm{S}\right)$, on infected pseudostem Musa acuminata var. Pisang Ambon (AAA), 23 Jun. 2014, N. Maryani, (holotype preserved as metabolically inactive culture, InaCC F917).

Notes: Fusarium kalimantanense represents a new clade (Clade 5) in FOSC, which was previously considered to include only four clades (Fig. 6; sensu O'Donnell et al. 2004). This species has relatively fast-growing colonies compared to those of other members of FOSC in this study, and has a unique character in its aseptate microconidia. Fusarium kalimantanense causes a slight infection on both Cavendish and Gros Michel. Further pathogenicity tests on other cultivars like Bluggoe (syn. Pisang Kepok, AAB) will be required to determine its race.

Fusarium sangayamense N. Maryani, L. Lombard, Kema \& Crous, sp. nov. MycoBank MB826811. Fig. 18. 
Etymology: Name reflects Sangayam, the location from where this species was collected in Indonesia.
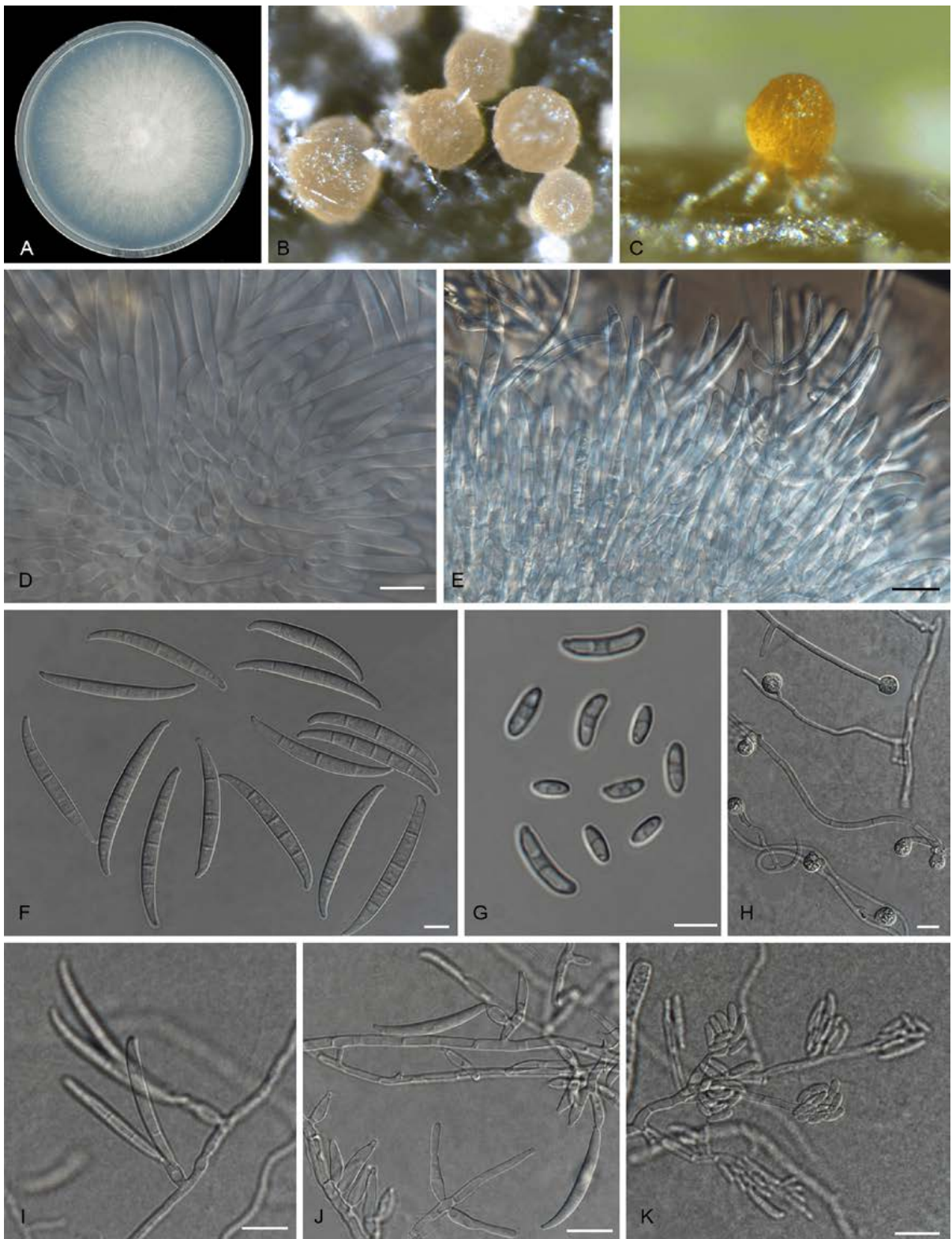

Fig. 17. Fusarium kalimantanense (ex-type InaCC F917). A. Culture grown on PDA. B-C. Sporodochia on carnation leaves. D-E. Sporodochial phialides. F. Falcate-shaped macroconidia. G. Microconidia. H. Thick-walled chlamydospores. I. Monophialides produce macroconidia. J. Branched conidiophores. K. False head. Scale bars D-K= $10 \mu \mathrm{m}$. 
Macroconidia abundant on CLA and SNA, rare on PDA, formed on sporodochia on CLA and on aerial conidiophores on SNA and PDA, falcate, (48-)52-60(-65) $\times(5-) 6-7(-8) \mu \mathrm{m}$ (av. $56 \times 7$ $\mu \mathrm{m}), 2-5$-septate, with apical cells papillate, basal cells foot-shaped. Conidiogenous cells monophialidic, similar in sporodochia and on hyphae, polyphialidic, rare, (6-)11-31(-47) × (3)4-6(-9) $\mu \mathrm{m}$. Microconidia abundant on PDA and SNA, less frequent on CLA, ovoid to ellipsoid, $(8-) 9-17(-24) \times(3-) 4-6(-7) \mu \mathrm{m}$ (av. $13 \times 5 \mu \mathrm{m}$ ), 0-1-septate, arranged in false heads on branched conidiophores borne on hyphae. Aerial conidiophores rare on CLA, and formed abundantly on SNA and PDA, sparsely branched, and formed laterally. Chlamydospores rarely produced on SNA after $7 \mathrm{~d}$, globose to subglobose, formed terminally or intercalarily, single or in pairs, $(6-) 7-10(-12) \times(6-) 7(-9) \mu \mathrm{m}$, rough-walled.
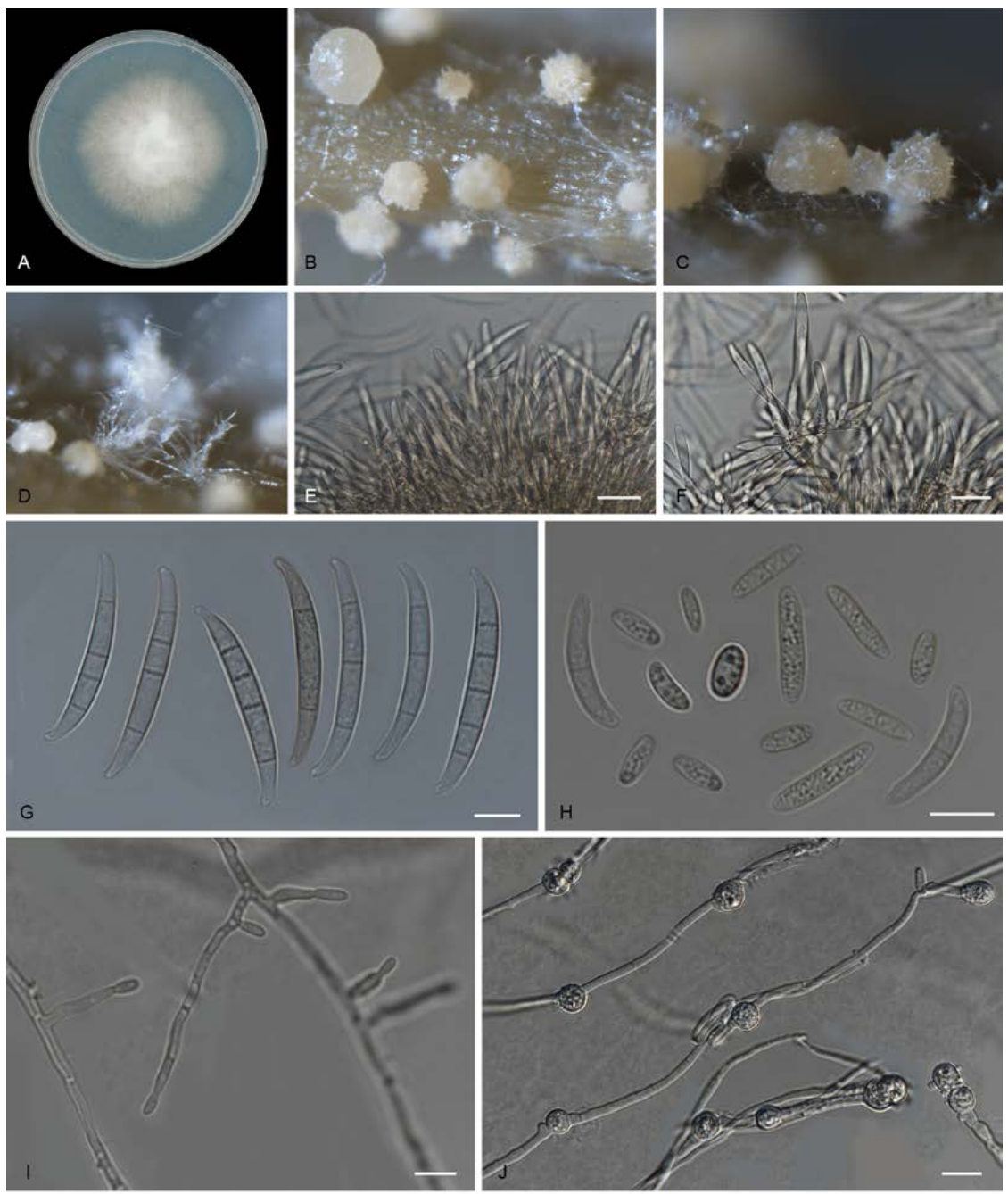

Fig. 18. Fusarium sangayamense (extype InaCC F960). A. Culture grown on PDA. B-C. Sporodochia on carnation leaves. D. Aerial conidiophore. E-F. Sporodochial phialides. G. Falcate-shaped macroconidia. H. Microconidia. I. Short monophialides. J. Thick-walled chlamydospores. Scale bars D-J=10 $\mu \mathrm{m}$. 
Culture characteristics: Colony on PDA showing optimal growth at $25{ }^{\circ} \mathrm{C}$, with an average growth rate of 3.5-4.2 mm/d. Colony reverse uniformly white and unpigmented. Colony surface dry, cottony, white, with filamentous margin and lacking exudates. Aerial mycelium abundant, cottony, with moderate sporulation. Sporodochia formed abundantly on CLA after $7 \mathrm{~d}$, pale orange.

Geography and host: Kota Baru, South Kalimantan, Musa sp. var. Pisang Kepok (ABB). Pathogenicity: Non-pathogenic on Gros Michel (AAA) and Cavendish (AAA).

Material examined: Indonesia, Sangayam, Kota Baru, South Kalimantan ( $\left.115^{\circ} 59^{\prime} 440^{\prime \prime} \mathrm{E}, 2^{\circ} 20^{\prime} 420^{\prime \prime} \mathrm{S}\right)$, on infected pseudostem of Musa sp. var. Pisang Kepok (ABB), 19 Jun. 2014, N. Maryani, (holotype preserved as metabolically inactive culture, InaCC F960).

Notes: Isolates of $F$. sangayamense formed a subclade in the new FOSC Clade 5 (Fig. 6) with high support ( $\mathrm{BP}=100 \%$ and $\mathrm{PP}=1.0$ ). Fusarium sangayamense can be distinguished from $F$. kalimantanense based on the septation of its macroconidia (2-5-septate) and microconidia (0-1-septate). This species has polyphialidic conidiogenous cells, which are absent in $F$. kalimantanense. Fusarium sangayamense was not able to infect Cavendish or Gros Michel.

\section{Pathogenicity assays}

The pathogenicity assay showed that all collected Foc isolates were able to cause typical Fusarium wilt symptoms on either Cavendish or Gros Michel, or in both varieties (Fig. 19). The positive control isolate Foc-II5 was lethal to both varieties, whereas all negative (water) controls remained free of disease. Isolates affecting Cavendish were classified as TR4 (Su et al. 1986), while those only infecting Gros Michel were classified as Race1 (Waite \& Stover 1960, Ploetz 1990). No fewer than $65 \%$ of the isolates clustered in L1, which only comprised the strains that caused Fusarium wilt in Cavendish and hence, represented TR4. The rest of the isolates tested were able to infect Gros Michel and are therefore considered to be Race1 strains. Strains fitting this pathogenicity profile were equally distributed over all other lineages, except L7 and L9. L7 contains two Indonesian isolates that caused a slight discolouration of the corms of both varieties. Isolates in the new clade within FOSC were not able to cause disease in either tested banana variety. Isolates identified as other Fusarium species in the phylogenetic analyses were negative in all pathogenicity assays. 

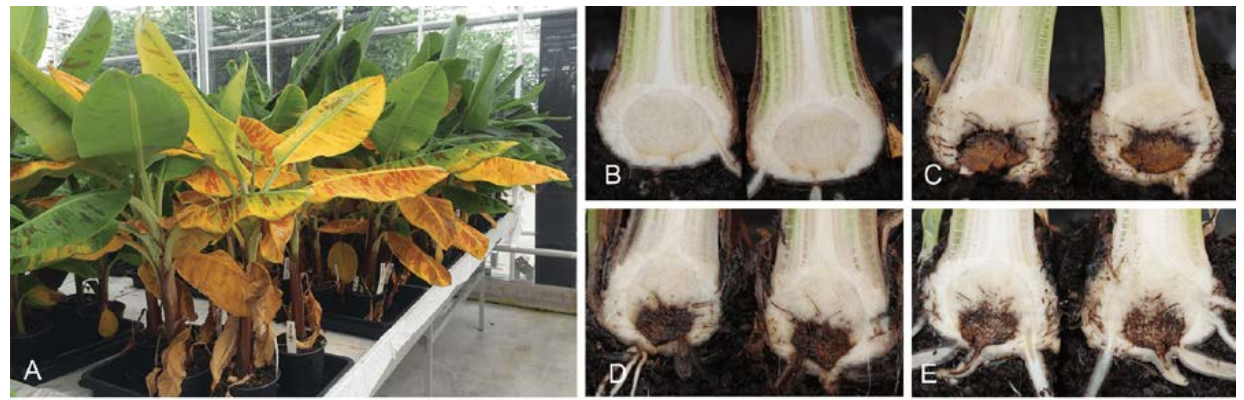

Fig. 19. Pathogenicity assays. A. External wilting symptoms. B-C. Left panel Cavendish and right panel Gros Michel, corm symptom caused by Race1, Fusarium tardichlamydosporum. D-E. Left panel Cavendish and right panel Gros Michel, corm symptom caused by TR4, Fusarium odoratissimum.

\section{DISCUSSION}

The Musa gene centre (Perrier et al. 2011), as with the wheat gene centre in the Middle-East (Banke et al. 2004, Stukenbrock et al. 2007) and that of potato in Central Mexico (Grünwald \& Flier 2005), contains a myriad of endemic diseases that co-evolved with the host. It is therefore considered a typical hot-spot of pathogen diversity (Stukenbrock et al. 2008). The gene centre of Musa has been studied in detail since the previous century. The wild ancestor of edible banana, Musa acuminata, originated in South-East Asia and Melanesia, and Musa balbisiana originated in South Asia (Perrier et al. 2011), where Indonesia is the contact area between these two wild Musa species. Approximately 11-13 Musa acuminata sub-species are of Indonesian origin, found in Sumatra, Kalimantan, Java, and the Lesser Sundas (Daniells 1995, Simmonds 1962). Most of the Musa balbisiana sub-species found in Java, Sumatra, and Sulawesi originate from India (Ochse \& van den Brink 1931, De Lange 2009). However, the genetic diversity of Musa pathogens in the centre of origin of Musa has remained virtually unsampled. Although a recent overview of Foc in Asia was published (Mostert et al. 2017), a need remained for a thorough taxonomic analysis of Foc in its centre of origin. Our results present the most comprehensive study of Foc in the Indonesian gene centre of banana to date. Isolates of Foc were recovered from all the samples that were collected in all areas surveyed. The results demonstrated that Fusarium wilt is widely distributed in Indonesia and could be found in every banana producing area surveyed. Past reports showing compatible results have spanned an area from Aceh province in the west to Papua province in the east (Nasir et al. 1999, Wibowo et al. 2011). In 2012, 1700 of the 21000 acres of cultivated banana suffered from Fusarium wilt in Indonesia, including large commercial Cavendish plantations (Jumjunidang et al. 2012). Factors making this disease difficult to control include traditional farming practices, limited quarantine restriction on movement of planting material, and limited knowledge on the dissemination of the pathogen(s). As a result, the disease is unwittingly distributed to new areas. Moreover, the abundant diversity of banana varieties in 
Indonesia allows farmers to easily change the varieties they grow, resulting in epidemiological contact that allows the pathogen to infect new cultivars in different areas.

Demographic factors could have played a significant role in the dissemination of this disease in Indonesia. Java is the most populated island and, therefore, banana production and the available cultivated varieties are the most numerous on this island, as is the pathogen. Mass migration of people from this over-populated island to less populated islands such as Kalimantan, Sumatra, and Papua from 1980 to1990 could account for the dissemination of Fusarium wilt throughout Indonesia, since infected banana planting material was taken along (Nasir et al. 1999).

The high number of local banana varieties from which Foc was recovered indicate that co-evolution of this pathogen is occurring along with its host in this region. Nasir et al. (1999) reported that 15 local varieties in Sumatra were susceptible to Fusarium wilt, including the most popular varieties, Pisang Ambon Kuning (AAA, Gros Michel synonym), Barangan (AAA) and Pisang Raja Sereh (AAA). This finding was reconfirmed in this study. An increasing number of infected varieties was also reported by Hermanto et al. (2009) and Jumjunidang et al. (2012). Of the hundreds of banana cultivars identified in Indonesia, many appear to be resistant or partially resistant to Fusarium wilt, a prior finding that was also observed during the present survey. No wild banana or close relative surveyed in this study showed any symptoms of Fusarium wilt. In Africa, Ensete ventricosum, a member of the Musaceae, is susceptible to Foc Race2 (Ploetz 2006a). By contrast, Ensete glaucum growing on the outskirt forest of Flores, Indonesia, was found to be healthy. None of the wild M. acuminata varieties found during the surveys was susceptible to Fusarium wilt. This finding is in agreement with some reports and greenhouse experiments on the infection of Foc on wild M. acuminata. $M$. acuminata var. malaccensis from the Malaysian Peninsula was reported to be experimentally resistant (Javed et al. 2004), as was its sister variety M. acuminata var. malaccensis from Sumatra (Ahmad \& Maryani 2017, unpubl. data). This study and our observations during surveys indicate that Indonesia is the primary gene centre of Foc, and the most likely place to find a diverse palette of disease resistance markers for Fusarium wilt in banana.

The high diversity of Foc isolates found in this study is unparalleled by the findings of any previous study (O'Donnell et al. 1998; Fourie et al. 2009) where a similar approach was used. The taking of larger numbers of samples in Indonesia inclusive of more banana cultivars, could result in an even higher diversity, as well as the discovery of yet more novel taxa belonging to FOSC. This accords with the view of Leslie \& Summerell (2006), who stated that the most informative studies on the systematics and evolution of Fusarium species from natural ecosystems, as well as different agro-ecosystems, should incorporate native host populations, in order to allow discovery of the full existing species diversity (Leslie \& Summerell 2006). 
Employing rotations with alternative crops, such as corn, sugar cane, peanuts and coffee, was found to decrease disease incidence in some plantations in Sumatra, Java, and Kalimantan. However, this practice probably has allowed for other Fusarium species, pathogenic to the rotation crops, to become established in these plantations, explaining their recovery in this study. These species include $F$. mangiferae, F. proliferatum $F$. sacchari and $F$. verticillioides, which are members of the Fusarium fujikuroi species complex (FFSC) and are associated with several tropical crops (Marasas et al. 2006, Ploetz 2006b) such as mango, maize, rice and sugarcane (Hsuan et al. 2011). These crops were commonly found in the areas surveyed for Fusarium wilt on bananas during this study. Fusarium proliferatum and $F$. oxysporum have been reported from the roots of the wild banana, Musa acuminata, from Malaysia (Zakaria \& Rahman 2011), which is closely related to several other M. acuminata varieties present in Sumatra and Java (Nasution 1990). This study represents the first report of both $F$. longipes and $F$. incarnatum-equiseti from banana varieties displaying symptoms of Fusarium wilt, although disease symptoms could not be induced in the pathogenicity assays undertaken here. However, both species are well-known as soil inhabitants and saprobes with a wide global distribution in tropical regions (Leslie \& Summerell 2006). They could, therefore, be secondary colonisers of the decaying vascular tissue collected during the survey. The majority of the isolates that clustered outside the FOSC clade are well-known endophytes of various plant hosts, saprobes, and soil inhabitants, and are known to be non-pathogenic to banana (Waalwijk et al. 1996, O’Donnell et al. 1998, Ploetz 2006a).

In the FOSC clade, the Indonesian isolates were equally distributed throughout the two previously known clades in FOSC (sensu O'Donnell et al. 2004). Several of these F. oxysporum isolates are known as endophytes of banana (O'Donnell et al. 1998), and are unable to induce disease on Cavendish or Gros Michel. Isolates obtained in this study that were found to be non-pathogenic to both banana cultivars tested were distantly related to the pathogenic isolates, and were more closely related to other formae speciales that are pathogenic to other crops. This finding supported the observations of Gordon \& Okamoto (1992), who reported that Fusarium oxysporum f. sp. melonis, pathogenic to cucurbits, is only distantly related to non-pathogenic strains. This also supports the view that Foc and other formae speciales of $F$. oxysporum have a polyphyletic origin (Baayen et al. 2000, O'Donnell et al. 2009).

Nine Foc lineages were revealed in this study, albeit with varying levels of statistical support, and described as new species. This conclusion was based on combinations of the genealogical approaches described by Dettmann et al. (2003) and Laurence et al. (2014), with supporting evidence from the inclusion of eight previously established lineages of FOC (O'Donnell et al. 1998; Fourie et al. 2009). A lineage is recognised as independent in this system if it is found to be concordantly supported by the majority of the loci, or is well supported by at least one locus but not contradicted by any other locus. Two previously known clades of Foc were resolved in this study (Boehm et al. 1994, Bentley et al. 1995, O'Donnell et 
al. 1998, Fourie et al. 2009), with the majority of the isolates fell into in Clade1, Lineage1. This lineage, classified as TR4, was found on every island surveyed, including Papua and Flores and those that were previously thought to be free of TR4. This is in agreement with some reports on Fusarium wilt in Indonesia, which note that the majority of Foc strains isolated appeared to be TR4 (O'Neill et al. 2011, Jumjunidang et al. 2012). In terms of phylogenetic diversity, TR4 isolates were less diverse than Race1, which occurred in almost all lineages. The number of diverse banana varieties sampled could be the reason for the tremendous diversity of Race1 isolates found in this study. Many of the banana sampled belong to varieties Gros Michel (AAA) or Silk (AAB), both known to be highly susceptible to Race1 (Waite \& Stover 1960).

The partial sequences of the three coding gene regions employed in this study, tef1, rpb1 and rpb2, are well-known to be robust for use in molecular-based identification of Fusarium species (O'Donnell et al. 2015), but are unable to distinguish all of the 24 Vegetative Compatibility Groups (VCGs; Puhalla 1985, Ordóñez et al. 2015) that are known to represent the widest genetic diversity of Foc. Direct VCG identification is a relatively objective but timeconsuming test, and the results indicate genetic similarity rather than genetic differences (Kistler 1997). Therefore, VCGs represent good phenotypic characters for assessing diversity within populations, but genetic relationships among VCGs need to be assessed by other molecular tools.

The high diversity found, based on the number of isolates recovered from different banana varieties and the high number of lineages resolved in this study, support the hypothesis that the pathogen(s) co-evolved with the host in the host's centre of origin (Ploetz \& Pegg 2006). The unique agro-ecosystems and variety of ecological niches found where banana cultivation is practiced in Indonesia provide a conducive environment for the pathogen to evolve. As mentioned above, subsistence farming in Indonesia has allowed for the dissemination of banana varieties with varying degrees of tolerance and resistance to Fusarium wilt. This practice may have created a suitable environment for the incumbent pathogen to evolve and to adapt to newly introduced banana varieties. The dynamics of host diversity in these agro-ecosystems will continue to select for new pathogens (Stukenbrock \& McDonald 2008), a process that, in this study, yielded a diversity of genotypes able to infect newly introduced banana cultivars.

Another scenario that could account for the high Foc diversity in Indonesia, irrespective of a lack of sexual reproduction, is horizontal gene transfer. Fusarium oxysporum has the ability to transfer specific chromosomes, sometimes containing unique pathogenicity genes, among non-pathogenic and pathogenic strains, resulting in new pathogenic lineages (Rep \& Kistler 2010). This phenomenon is well recorded in Fusarium oxysporum f. sp. lycopersici, a pathogen of tomato (Ma et al. 2010). A recent study of the effector profile of different formae speciales of $F$. oxysporum, including Foc, indicated that these fungi have specific and unique effector profiles that reflect vertical and horizontal inheritance (van Dam et al. 2016). The 
endophytic character of some $F$. oxysporum strains, some of which are weak soil-borne pathogens (Stover 1962b), allows for relatively easy assimilation of pathogenicity genes from related pathogenic $F$. oxysporum strains via horizontal gene transfer (Vlaardingerbroek et al. 2016).

It was initially thought that the origin of pathogenic Foc is from non-pathogenic root inhabitants or endophytes of various wild M. acuminata plants in Java and Sulawesi that became pathogenic after their introduction to foreign banana germplasm (Buddenhagen 2007). Alternatively, native Race1 isolates may have been exposed to selection pressure through exposure to newly introduced banana varieties, as Race1 is known to infect diverse varieties like Silk (AAB), Pome (AAB), and Pisang Awak (ABB) (Waite \& Stover 1960, Ploetz 2006a). Isolates that clustered in the newly resolved subclade in the FOSC in this study were found to be non-pathogenic towards both Cavendish and Gros Michel. These isolates only caused initial discoloration in the corm, without any further disease development. They might be pathogenic on other germplasm, but until more banana varieties can be tested, this idea remains speculation.

Our study demonstrates that the Indonesian Foc population might be the most genetically diverse Foc ever studied. Further genetic study of this population using deeper genomic coverage should now be conducted. Pathogenicity tests using more banana varieties could be used to assess the wide range of pathogenicity.

Our study gives an insight into the complexity of Fusarium wilt on banana in Indonesia. This is very important for disease management not only in Indonesia but also worldwide. As the pathogen continues to evolve, new lineages could arise and escape Indonesia. In striving to find banana resistance to Fusarium wilt, researchers should consider the high diversity of Indonesian Foc reported here as one of the main obstacles to overcome.

\section{ACKNOWLEDGEMENTS}

This research was supported by the KNAW-SPIN Project, "The Indonesian banana: Protecting a staple food from Panama disease collapse and exploiting its genetic diversity for discovery research". N. Maryani was also supported by a DIKTI (Directorate General of Higher Education) Scholarship, Ministry of Research, Technology and Higer Education, Indonesia. The authors would like to thank Dr. Sarah M. Schmidt (Institute for Molecular Physiology, Heinrich-Heine-Universität Düsseldorf and Max Plank Institute for Plant Breeding Reseach, Köln, Germany), Fajarudin Ahmad (research Centre for Biology, LIPI, Cibinong, Indonesia), and Muhammad Ilyas (Indonesian Culture Collection, InaCC, LIPI, Cibinong, Indonesia) for participating in the sampling expeditions in Java, Sumatra, and Kalimantan. We also like to thank Dr. Marcelo Sandoval-Denis (Westerdijk Fungal Biodiversity Institute) for helpful discussions and technical support and Dr. Kerry O'Donnell (USDA) for the FOSC dataset. 


\section{REFERENCES}

Baayen RP, O'Donnell K, Bonants PJM, et al. (2000). Gene Genealogies and AFLP Analyses in the Fusarium oxysporum Complex Identify Monophyletic and Nonmonophyletic Formae Speciales Causing Wilt and Rot Disease. Phytopathology 90: 891-900.

Banke S, Peschon A, McDonald BA (2004). Phylogenetic analysis of globally distributed Mycosphaerella graminicola population based on three DNA sequence loci. Fungal Genetics and Biology 41(2): 226-238.

BPS (2017). Badan Pusat Statistik (BPS), Statistics Indonesia, Produksi Tanaman Hortikultura. https://www.bps.go.id/.

Bentley S, Pegg KG, Dale JL, et al. (1995). Genetic variation among a world-wide collection of isolates of Fusarium oxysporum f. sp. cubense analysed by RAPD-PCR fingerprinting. Mycological Research 99: 1378-1384.

Bentley S, Pegg KG, Moore NY (1998). Genetic variation among vegetative compatibility groups of Fusarium oxysporum f. sp. cubense analyzed by DNA fingerprinting. Phytopathology 88: 1283-129.

Boehm E, Ploetz R, Kistler CH (1994). Statistical analysis of electrophoretic karyotype variation among vegetative compatibility groups of Fusarium oxysporum f. sp. cubense. MPMI-Molecular Plant Microbe Interactions 7: $196-207$.

Booth C (1971). The Genus Fusarium. CAB, commonwealth Mycological Institute, UK.

Buddenhagen I (2007). Understanding strain diversity in Fusarium oxysporum f. sp. cubense and history of introduction of "Tropical Race 4" to better manage banana production. Proceedings of International Symposium on Recent Advances in Banana Crop Protection for Sustainable Production and Improved Livelihoods 828: 193-204.

Crous PW, Gams W, Stalpers JA, et al. (2004). MycoBank: an online initiative to launch mycology into the 21st century. Studies in Mycology 50: 19-22.

Daniells J (1995). Illustrated guide to the identification of banana varieties in the South Pacific. ACIAR Monograph 33:1-49.

De Langhe E (2009). Relevance of banana seeds in archaeology. Ethnobotany Research and Applications 7: 271281.

Dettman JR, Jacobson DJ, Taylor JW (2003). A multilocus genealogical approach to phylogenetic species recognition in the model eukaryote Neurospora. Evolution, 57(12), 2703-2720.

Dita MA, Waalwijk C, Buddenhagen I, et al. (2010). A molecular diagnostic for tropical race 4 of the banana fusarium wilt pathogen. Plant Pathology 59: 348-357.

FAOSTAT (2017). FAO statistics. http://www.fao.org/faostat/.

Fisher NL, Burgess LW, Toussoun TA, et al. (1982). Carnation leaves as a substrate and for preserving cultures of Fusarium species. Phytopathology 72: 151-153.

Fourie G, Steenkamp ET, Gordon TR, et al. (2009). Evolutionary relationships among the Fusarium oxysporum $\mathrm{f}$. sp. cubense vegetative compatibility groups. Applied and Environmental Microbiology 75: 4770-4781.

Garcia F, Alexander V, Nakasato TG, et al. (2018). A high throughput phenotyping method for the banana Fusarium oxysporum f. sp. cubense pathosystem, with wider application for other Fusarium oxysporum host relationships. In prep.

Gerlach KS, Bentley S, Moore NY, et al. (2000). Characterisation of Australian isolates of Fusarium oxysporum $\mathrm{f}$. sp. cubense by DNA fingerprinting analysis. Australian Journal of Agricultural Research 51: 945-953.

Gordon T, Okamoto D (1992). Population structure and the relationship between pathogenic and nonpathogenic strains of Fusarium oxysporum. Phytopathology 82: 73-77.

Groenewald S, Van Den Berg N, Marasas WFO, et al. (2006). The application of high-throughput AFLP's in assessing genetic diversity in Fusarium oxysporum f. sp. cubense. Mycological Research 110: 297-305.

Grünwald NJ, Flier WG (2005). The biology of Phytophthora infestans at its center of origins. Annual Review Phytopathology 43: 171-190.

Hermanto C, Sutanto A, Jumjunidang, et al. (2009). Incidence and distribution of Fusarium wilt disease of banana in Indonesia. International ISHS-ProMusa Symposium on Global Perspectives on Asian Challenges 897: 313-322.

Hsuan HM, Salleh B, Zakaria L (2011). Molecular identification of Fusarium species in Gibberella fujikuroi species complex from rice, sugarcane and maize from Peninsular Malaysia. International Journal of Molecular Sciences 12: 6722-6732.

Javed MA, Chai M, Othman RY (2004). Study of Resistance of Musa acuminata to Fusarium oxysporum using RAPD markers. Biologia Plantarum 48: 93-99.

Jumjunindang, Edison, Riska, et al. (2012). Penyakit layu Fusarium pada tanaman pisang di provinsi NAD: Sebaran dan identifikasi isolat berdasarkan analisis vegetative compatibility group. Jurnal Hortikultur 22: 164-171. 
Katoh K, Standley DM (2013). MAFFT multiple sequence alignment software version 7: improvements in performance and usability. Molecular Biology and Evolution 30: 772-780.

Kistler HC (1997). Genetic diversity in the plant-pathogenic fungus Fusarium oxysporum. Phytopathology 87(4): 474-479.

Koenig R, Ploetz R, Kistler HC (1997). Fusarium oxysporum f. sp. cubense consists of a small number of divergent and globally distributed clonal lineages. Phytopathology 87: 915-923.

Komada H (1975). Development of a selective medium for quantitative isolation of Fusarium oxysporum from natural soil. Review of Plant Protection Research 8: 114-124.

Laurence MH, Summerrell BA, Burgess LW, et al. (2014). Genealogical concordance phylogenetic species recognition in the Fusarium oxysporum species complex. Fungal Biology 118: 374-384.

Leslie JF, Summerell BA (2006). The Fusarium laboratory manual. Blackwell Publishing Ltd, UK.

Ma L, Van Der Does HC, Borkovich KA, et al. (2010). Comparative genomics reveals mobile pathogenicity chromosomes in Fusarium. Nature 464: 367-373.

Marasas WFO, Ploetz RC, Wingfield MJ, et al. (2006). Mango malformation disease and the associated Fusarium species. Phytopathology 96: 667-672.

Mason-Gamer R, Kellogg E (1996). Testing for phylogenetic conflict among molecular datasets in the tribe Triticeae (Graminae). Systematic Biology 45: 525-545.

Moore NY, Pegg KG, Allen RN, et al. (1993). Vegetative compatibility and distribution of Fusarium oxysporum $\mathrm{f}$. sp. cubense in Australia. Animal Production Science 33: 797-802.

Mostert D, Molina A, Daniells J, et al. (2017). The distribution and host range of the banana Fusarium wilt fungus, Fusarium oxysporum f. sp. cubense, in Asia. PLoS ONE 12(7) e0181630.

Nasir N, Pittaway PA, Pegg KG, et al. (1999). A pilot study investigating the complexity of Fusarium wilt of bananas in West Sumatra, Indonesia. Australian Journal of Agricultural Research 50: 1279-1283.

Nasution RE (1990). A Taxonomic Study of the Species Musa acuminata Colla with its Intraspesific Taxa in Indonesia. Ph.D dissertation. Tokyo University of Agriculture, Japan.

Nasution RE (1993). Rediscovery of two wild seeded bananas of Indonesia. Infomusa 2: 16-17.

Nirenberg HI (1981). A simplified method for identifying Fusarium sp. occurring on wheat. Canadian Journal of Botany 59: 1599-1609.

O'Donnell K, Kistler CH, Cilgenik E, et al. (1998). Multiple evolutionary origins of the fungus causing Panama disease of banana: Concordant evidence from nuclear and mitochondrial gene genealogies. Proceedings of the National Academy of Sciences of the USA 95: 2044-2049.

O'Donnell K, Sutton DA, Rinaldi MG, et al. (2004). Genetic diversity of human pathogenic members of the Fusarium oxysporum complex inferred from multilocus DNA sequence data and amplified fragment length polymorphism analyses: evidence for the recent dispersion of a geographically widespread clonal lineage and nosocomial origin. Journal of Clinical Microbiology 42: 5109-5120.

O'Donnell K, Sutton DA, Rinaldi MG, et al. (2010). Internet-accessible DNA sequence database for identifying fusaria from human and animal infections. Journal of Clinical Microbiology 48: 3708-3718.

O'Donnell K, Sutton DA, Rinaldi MG, et al. (2009). A two-locus DNA sequence database for typing plant and human pathogens within the Fusarium oxysporum species complex. Fungal Genetics and Biology 46: 936948

O'Donnell K, Ward TJ, Robert VARG , et al. (2015). DNA sequence-based identification of Fusarium: Current status and future directions, Phytoparasitica 15, 583-595.

O'Neil WT, PAttison AB, Daniells JW, et al. (2011). Vegetaitive compatibility group analysis of Indonesian Fusarium oxysporum f. sp. cubense isolates. Acta Horticulturae 897: 345-352.

Ordóñez N, Seidl MF, Waalwijk C, et al. (2015). Worse comes to worst: bananas and Panama disease-when plant and pathogen clones meet. PLoS Pathogens 11: e1005197.

Ordóñez N (2018). A global genetic diversity analysis of Fusarium oxysporum f. sp. cubense, the Panama disease pathogen of banana. Ph.D dissertation. Experimental Plant Sciences, Wageningen University, The Netherlands.

Ochse JJ, Bakhuizen van den Brink RC (1931). Vegetables of the Dutch East Indies : edible tubers, bulbs, rhizomes and spices included : survey of the indigenous and foreign plants serving as pot-herbs and side-dishes. Nijhoff, The Hague, NL.

Perrier X, De Langhe E, Donohue M, et al. (2011). Multidisciplinary perspectives on banana (Musa sp.) domestication. Proceedings of the National Academy of Sciences of the USA 108: 11311-11318.

Ploetz RC (1990). Variability in Fusarium oxysporum f.sp. cubense. Canadian Journal of Botany 68(6): 1357-1363.

Ploetz RC, Pegg K (1997). Fusarium wilt of banana and Wallace's line: Was the disease originally restricted to his Indo-Malayan region?. Australian Plant Pathology 26: 239-249. 
Ploetz RC (1994). Panama disease: return of the first banana menace. International journal of pest management 40: 326-336.

Ploetz R, Pegg K (1997). Fusarium wilt of banana and Wallace's line: Was the disease originally restricted to his Indo-Malayan region? Australasian Plant Pathology 26(4), 239-249.

Ploetz RC (2006a). Panama disease, an old nemesis rears its ugly head: part 2, the cavendish era and beyond. Plant Health Progress March: 1-17.

Ploetz RC (2006b). Fusarium-Induced Diseases of Tropical, Perennial Crops. Phytopathology 96: 648-652.

Puhalla JE (1985). Classification of strains of Fusarium oxysporum on the basis of vegetative compatibility. Canadian Journal of Botany 63: 179-183.

Rayner RW (1970). A mycological colour chart. Commonwealth mycological Institute, Kew, UK.

Rep M, Kistler HC (2010). The genomic organization of plant pathogenicity in Fusarium species. Current Opinion in Plant Biology 13: 420-426.

Ronquist F, Telsenko M, Van Den Mark P, et al. (2012). MrBayes 3.2: efficient Bayesian phylogenetic inference and model choice across a large model space. Systematic Biology 61: 539-542.

Simmonds N (1962). The Evolution of Bananas. Longman Itd, UK.

Simmonds N, Shepherd K (1955). The taxonomy and origins of the cultivated bananas. Journal of the Linnean Society of London, Botany 55: 302-312.

Smith $F$ (1910). A cuban banana disease. Science 31: 746-757.

Stamatakis A (2014). RAxML version 8: a tool for phylogenetic analysis and post-analysis of large phylogenies. Bioinformatics 30: 1312-1313.

Stover RH (1962a). Fusarial wilt (Panama Disease) of bananas and other Musa species. Oxford university press, Oxford, UK.

Stover RH (1962b). Studies on Fusarium wilt of bananas: IX competitive saprophytic ability of Fusarium oxysporum f. sp. cubense. Canadian Journal of Botany 40: 1473-1481.

Stukenbrock EH, Banke S, Javan-Nikhah M et al. (2007). Origin and domestication of the fungal wheat pathogen Mycosphaerella graminicola via sympatric speciation. Molecular biology and evolution 24(2): 398-411.

Stukenbrock EH, McDonald BA (2008). The origins of plant pathogens in agro-ecosystems. Annual Review of Phytopathology 46: 75-100.

Su HJ, Hwang SC, Ko WH (1986). Fusarial wilt of Cavendish bananas in Taiwan. Plant Disease 70: 814-818.

Tamura K, Peterson D, Peterson N, et al. (2013). MEGA6: molecular evolutionary genetics analysis version 6.0 . Molecular Biology and Evolution 30: 2725-2729.

Valmayor RV, Jamaluddin SH, Silayoi JSB, et al. (1999). Banana cultivar names and synonyms in Southeast Asia. INIBAP, Montpellier, France.

Van Dam P, Fokkens L, Schmidt SM, et al. (2016). Effector profiles distinguish formae speciales of Fusarium oxysporum. Environmental Microbiology 18: 4087-4102.

Vlaardingerbroek I, Beerens B, Rose L, et al. (2016). Exchange of core chromosomes and horizontal transfer of lineage-specific chromosomes in Fusarium oxysporum. Environmental Microbiology 18: 3702-3713.

Waalwijk C, Baayen R, De Koning J, et al. (1996). Ribosomal DNA analyses challenge the status of Fusarium sections Liseola and Elegans. Sydowia 48: 90-104.

Waite BH, Stover RH (1960). Studies on Fusarium wilt of bananans. VI. variability and the cultivars concept in Fusarium oxysporum f. sp cubense. Canadian Journal of Botany 38: 985-994.

Wibowo A, Subandiyah S, Sumardiyono C, et al. (2011). Occurrence of Tropical Race 4 of Fusarium oxysporum $\mathrm{f}$. sp. cubense in Indonesia. Journal Plant Pathology 27(3): 280-284.

Zakaria L, Rahman NHA (2011). Endophytic Fusarium sp. from wild banana (Musa acuminata) roots. African Journal of Microbiology Research 5: 3600-3602. 



\section{Chapter 3}

\section{Genotyping-by-sequencing reveals extensive genotypic diversity among sympatric Fusarium wilt pathogens of banana in Indonesia}

Nani Maryani ${ }^{1,2,3}$, Michael F. Seidl ${ }^{2}$, Pedro W. Crous ${ }^{4}$, and Gerrit H.J. Kema ${ }^{1,2}$

\footnotetext{
'Biointeractions and Plant Health, Wageningen Plant Research, Wageningen University and Research, Wageningen, The Netherlands; ${ }^{2}$ Laboratory of Phytopathology, Wageningen University and Research, Wageningen, The Netherlands; ${ }^{3}$ Biology Education, Faculty of Education, Universitas Sultan Ageng Tirtayasa (UNTIRTA), Banten, Indonesia; ${ }^{4}$ Westerdijk Fungal Biodiversity Institute, Utrecht, The Netherlands
} 


\begin{abstract}
Several Fusarium species in the Fusarium oxysporum species complex (FOSC) are known to cause Fusarium wilt on banana, a devastating disease with worldwide significance. Extensive genetic diversity of this pathogen is found in South-East Asia - the centre of origin of bananas. Here, we assessed the genetic diversity of the largest collection of Fusarium species causing Fusarium wilt that were isolated from local banana varieties in Indonesia using genotypingby-sequencing through Diversity Array Technology (DArTseq). We show that this technique is appropriate to rapidly assess genetic diversity at high resolution below the species level and that it provides dense and well-distributed markers over the reference Fusarium odoratissimum II5 genome. By hierarchical clustering of DArTseq markers, we identified 19 DArT Genotype Group (DGGs) of the 10 Fusarium species included. Most isolates ( $55 \%$ ) belong to $F$. odoratissimum and are grouped in a single DGG and were highly pathogenic on the Cavendish banana variety Grand Naine, thus classified as Tropical Race 4 (TR4). In contrast to TR4, Race 1 isolates were genetically more diverse, being distributed over six DGG and were highly pathogenic on the variety Gros Michel. Collectively, our results provide strong evidence that Fusarium spp. co-evolved with banana, and thus besides being the centre of diversity for the host, Indonesia likely also represents the centre of origin of Fusarium species causing Fusarium wilt in banana.
\end{abstract}

Keywords: Co-evolution, DArTseq, genotype, Race 1, species, Tropical Race 4 


\section{Introduction}

Several Fusarium species, members of Fusarium oxysporum species complex (FOSC), are devastating plant pathogens that causes Fusarium wilt on banana (Maryani et al. 2019). A wide-range of banana varieties is susceptible to these pathogens, hence banana-producing countries around the world are affected. Fusarium wilt causes major problems in banana cultivation, both in small-scale plantations for domestic consumption like in Indonesia, India and Uganda, as well as in big monoculture plantations that produce banana for export purposes like in Colombia, Ecuador and The Philippines (Ploetz et al. 2015). Once banana plants are infected by Fusarium spp., the mycelium will ramify plant tissue, resulting in reduced fruit production or plant death. Moreover, the fungus simultaneously produces persistent chlamydospores that reside in debris and infested soil and remain viable for decades (Stover \& Waite 1960, Ploetz 2015).

A thorough phylogenetic study of hundreds of Fusarium oxysporum isolates from the centre origin of banana in Indonesia as well as from a worldwide collection revealed several phylogenetic species within the FOSC and thus new names and formal descriptions were assigned for each of these new Fusarium species with pathogenicity to banana (Maryani et al. 2019). Fusarium spp. and its banana hosts likely co-evolved in South-East Asia (Groenewald et al. 2006, Koenig et al. 1997, Ploetz \& Pegg 1997), which is the centre of origin of wild and cultivated bananas. The two wild banana ancestors, Musa acuminata Colla (AA, $2 n=22$ ) and Musa balbisiana Colla $(B B, 2 n=22)$, diversified into various edible varieties that include diploid (AA, BB), triploid (AAA, AAB, ABB) and tetraploid (ABBB) genotypes (Simmonds 1962). The Indonesian archipelago represents the primary centre for banana diversity, where the majority of wild species and cultivated varieties ( $>500)$ are grown (Perrier et al. 2011, Nasution 1990). Therefore, pathogens are considered to have co-evolved with their hosts in such regions. Although previous of Fusarium population studies have been limited in size, they provided strong evidence for co-evolution with the host in South-East Asia (Koenig et al. 1997, Ploetz \& Pegg 1997, Groenewald et al. 2006). However, Fusarium spp. also might have evolved independently in other parts of the world upon the introduction of bananas (O'Donnell et al. 1998, Stover 1972). This is in accord with the recent identification of eight phylogenetic species of Fusarium spp. from the centre origin of banana in Indonesia and one phylogenetic species from Africa (Maryani et al. 2019). Studying the genetic diversity of these banana infecting Fusarium pathogens in Indonesia is therefore essential to increase the understanding of their evolution (Ploetz 1990, Ploetz \& Pegg 1997).

Genetic diversity of pathogen populations has been studied using various genetic markers. In the Fusarium spp. that affect banana, phenotypic markers were commonly used to characterize pathotypes and vegetative compatibility groups (VCGs). Pathotypes or races are identified by differential host responses. Previous pathotyping assays have recognized three races (1, 2 and 4) in the Fusarium - banana pathosystem (Stover 1962, Su et al. 1986). 
These were, however, based on a very limited number of bananas - Fusarium isolates interactions and concluded that Race 1 is virulent on Gros Michel (AAA), Race 2 is virulent on Bluggoe (ABB), while Race 4 is virulent on Cavendish (AAA). Under abiotic stresses Cavendish plants are vulnerable and strains affecting it under such conditions are classified as Subtropical Race 4 (STR4). Strains that infect Cavendish irrespective of abiotic conditions are identified as Tropical Race 4 (TR4) and are also virulent on Gros Michel and Bluggoe (Ploetz 1990, Stover 1962, Su et al. 1986). However, pathogenicity assays to determine races are laborious, while the underlying genotypes of the tested host and pathogen accessions remain unknown (Milgroom 2015, Kistler 1997). Genetic identity or proximity is based on heterokaryon formation, which occurs between strains in the same group of isolates (Puhalla 1985), and such isolates are considered to belong to the same VCG (Leslie 1993, Puhalla 1985). Thus far, Fusarium isolates from banana affected with Fusarium wilt have been placed in 24 VCGs but the underlying genotypes are still unknown (Ordóñez et al. 2015, Ploetz 2006). Moreover, VCGs do not provide information on virulence and do not correlate with the known phylogenetic species (Maryani et al. 2019, Fourie et al. 2009, O’Donnell et al. 1998, Moore et al.1993). Therefore, although race and VCG determination are useful phenotypic markers, further genetic assessment is needed to study diversity of pathogen populations at a higher resolution (Kistler 1997).

To determine genotypic diversity of Fusarium isolates that affect banana, DNA markers are preferred over phenotypic markers as these are able to capture molecular variation. Many molecular techniques have been used to assess genetic diversity in Fusarium fungi that infect banana (Bentley et al. 1995, Bentley et al. 1998, Koenig et al. 1997, Groenewald et al. 2006). However, the results obtained from these studies were not always congruent. Groenewald et al. (2006) and Bentley et al. (1998) analysed the same fungal populations causing wilt on banana using DNA fingerprinting and amplified fragment length polymorphism (AFLP), respectively, resulting in different genotypic groups. Genome-wide, high-resolution and reproducible markers are required for observing genetic differentiation of pathogen populations (Metzker 2009, Elshire et al. 2011, Agrawal \& Shrivastava 2014). Genotyping-bysequencing meets these requirements and therefore, we used Diversity Array Technology sequencing (DArTseq) (Ordóñez et al. 2015) to simultaneously genotype hundreds of polymorphic loci across the entire genome (Cruz et al. 2013, Jaccoud et al. 2001).

Here, we discovered novel genotypic diversity among Indonesian Fusarium spp. causing Fusarium wilt in banana (Maryani et al. 2019). We analysed 10 Fusarium species comprising 196 isolates and discovered at least 19 genotypes across the known FOSC causing Fusarium wilt in banana. This extensive sympatric diversity is independent of the geographical origin or the affected host plant and is therefore likely driven by a banana - Fusarium coevolution in Indonesia. 


\section{Materials and Methods}

\section{Fungal isolates}

The pseudostems of Fusarium wilt-infected banana varieties were collected across Indonesia on the islands of Flores, Java, Kalimantan, Papua, Sulawesi and Sumatra (Table 1; Fig. 1). Phylogenetic analyses of the Fusarium spp. recovered from these samples revealed several phylogenetic species in the FOSC (Maryani et al. 2019). Additionally, isolates from a worldwide collection known to represent various races and VCGs were included in the analyses (Ordóñez et al. 2015) (Table 1). Monosporic isolates were obtained and maintained on Potato Dextrose Agar (PDA) as a working collection and in glycerol $20 \%$ (stored at $-80{ }^{\circ} \mathrm{C}$ ) for long-term preservation (Maryani et al. 2019). The entire collection is maintained in the Indonesia Culture Collection (InaCC), Cibinong, Indonesia, and at Wageningen University and Research (WUR), Wageningen, The Netherlands.

\section{DNA extraction and DArTseq markers}

Monosporic cultures of each isolate were grown in Potato Dextrose Broth (PDB) and incubated under continuous shaking (125 rpm) at room temperature. After seven days of incubation, fungal biomass was collected by filtering the cultures through cheesecloth and samples were subsequently lyophilized in a $2 \mathrm{~mL}$ tube for $21 \mathrm{~h}$. Genomic DNA of each isolate was extracted using the DNA-Kit Wizard Magnetic DNA Purification System for Food kit (Promega, USA), quantified using the Quant-iT ${ }^{\mathrm{TM}}$ PicoGreen $^{\mathrm{TM}}$ dsDNA Reagent Invitrogen in a TECAN 2000 analyser (Thermo Fisher Scientific, Switzerland), and quality checked on an agarose gel. DNA samples of high quantity and quality $(500 \mathrm{ng} ; 100 \mathrm{ng} / \mathrm{uL}$ ) of each isolate were used for DArTseq analyses. DArTseq markers were generated by Diversity Arrays Technology Pty. Ltd. (http://www.diversityarrays.com), Canberra, Australia, using a genome complexity reduction method and sequencing with the Illumina sequencing platform (Kilian et al., 2012), an approach that has been modified for Fusarium oxysporum species (Ordóñez et al., 2015).

\section{Mapping of DArTseq markers and cluster analyses}

Polymorphic DArTseq markers (binary markers indicating the presence [positive/'1'] or absence [negative/'0'] of a specific marker in a respective isolate) were used as input for the cluster analyses. Isolates with less than 500 positive markers were removed from subsequent analyses. Additionally, DArTseq markers were filtered for genotype call rate $(>0.66)$ and reproducibility $(=1)$. A binary distance matrix between isolates was calculated using Dice similarity coefficients. Isolates were then clustered using the distance matrix as an input for the UPGMA (Unweighted Pair Group Method with Arithmetic Mean) clustering method. The analyses were performed in R software (http://www.R-project.org) (RDevelopment-CoreTeam 2013). To determine genetic differences within the species (among isolates), DArT 
Genotype Group (DGG) were defined as a group of isolates with less than 0.1 Dice distance in the cluster.

To determine the genomic distribution of the derived DArTseq markers, the nucleotide sequence of each DArT marker sequence (up to $69 \mathrm{nt}$ ), was mapped to the reference II5 genome assembly (http://www.broadinstitute.org/) using blastn (megablast, e-value cutoff 1e-10) (Morgulis et al. 2008). For each marker sequence of which $\geq 80 \%$ of its sequence could be placed on the II5 genome assembly, the 'best' genomic location was reported. For each marker that could potentially be placed at more than one genomic location, we defined the 'best' location for this particular marker by considering the bitscore differences of its individual hits, i.e. a marker with a bitscore difference $<5$ between the two 'best' locations was not placed, while a marker with a bitscore difference $\geq 5$ was placed at the highest scoring location. Marker distributions for the largest 20 Fusarium odoratissimum II5, scaffolds were visualized using the R package ggbio (Yin et al. 2012), and (upstream) distances (in nt) between individual marker positions were calculated and visualized using $\mathrm{R}$.

\section{RESULTS}

A comprehensive collection of Fusarium species causing Fusarium wilt in banana across Indonesia

Surveys of Fusarium wilt in Indonesia were conducted in 2014 and 2015. As bananas in Indonesia are commonly produced in backyard home plantations, samples were obtained from mixed banana varieties (Maryani et al. 2019). We sampled a total of 172 Indonesian isolates from 40 local banana varieties (Table 1). Samples were collected at 34 geographically diverse sites in 15 provinces, distributed over the islands of Flores, Java, Kalimantan, Papua, Sulawesi and Sumatra (Fig. 1). We obtained most isolates from Java (74 isolates) and Kalimantan (52 isolates), followed by Sumatra (18 isolates), Flores (14 isolates), Papua (10 isolates) and Sulawesi (8 isolates) (Fig. 1). Taken together, we observed Fusarium wilt occurring on many banana accessions at every location (Maryani et al. 2019), indicating that the disease is well-spread across the Indonesian archipelago.

\section{Abundance and distribution of DArTSeq markers}

DArTseq analyses from a total of 196 isolates (Table 1) resulted in 13150 polymorphic DArTSeq markers. Technical repeats ( 40 isolates) and biological repeats ( 24 isolates) of DArT assays produced the same sets of DArTSeq markers, indicating good repeatability and reproducibility of the assays. To assess the density and the distribution of the markers over the $F$. odoratissimum genome, we placed the DArTseq markers onto the genome assembly of the reference isolate II5. In total, 6051 DArTSeq markers ( $46 \%$ ) could be mapped to the II5 genome assembly with high confidence and these markers were evenly distributed across the largest 20 scaffolds (Fig. 2A and 2B). The genomic distances between the DArTseq markers 
were generally small (3 308 markers have a distance $<5 \mathrm{~kb}$ ) (Fig. 2C). Thus, given the estimated genome size of the II5 assembly (46.5 MB), on average one DArTseq marker per $7.6 \mathrm{~kb}$ can be observed. Therefore, DArT technology delivers abundant and dense marker sets for genetic diversity assessment.

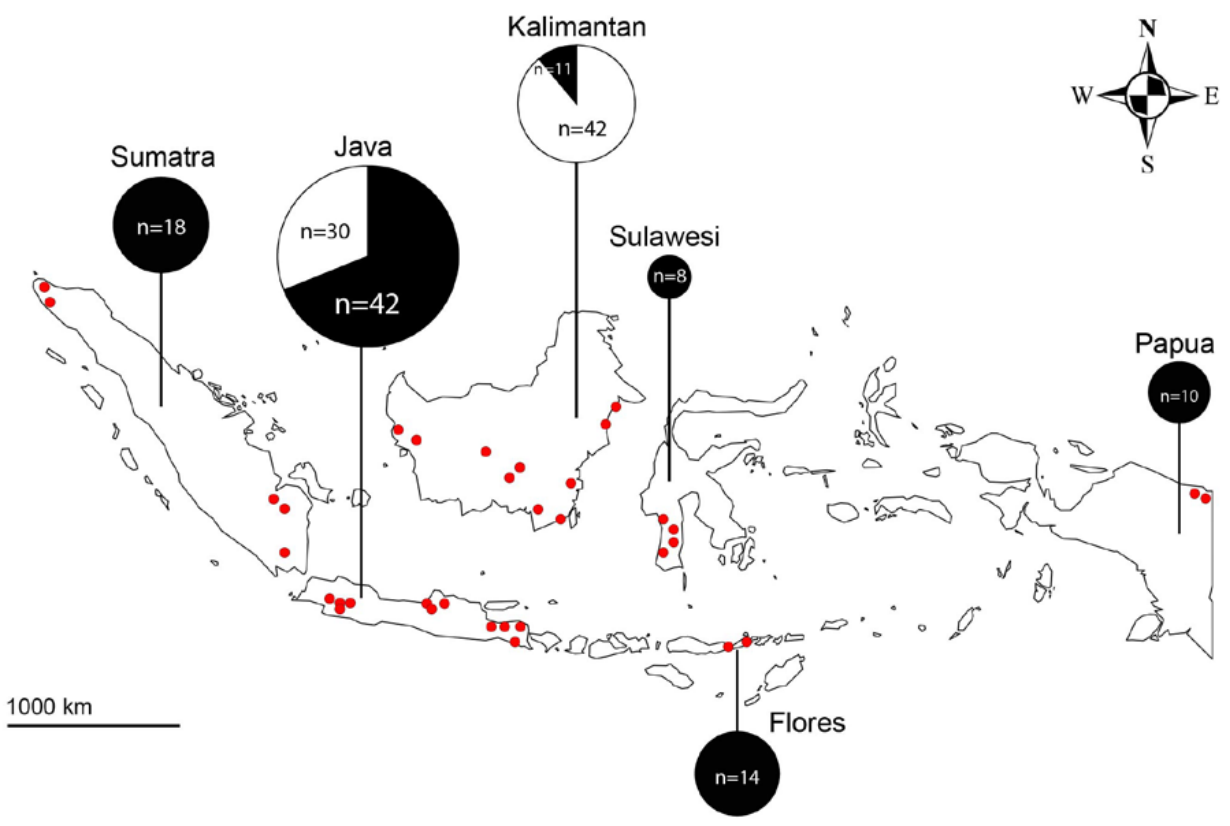

Fig. 1. Sampling sites of Fusarium spp. from banana plants affected by Fusarium wilt on six Indonesian islands indicated by red dots. Pie charts indicate the total number of obtained isolates and the number of $F$. odoratissimum Tropical Race 4 strains (in black). 


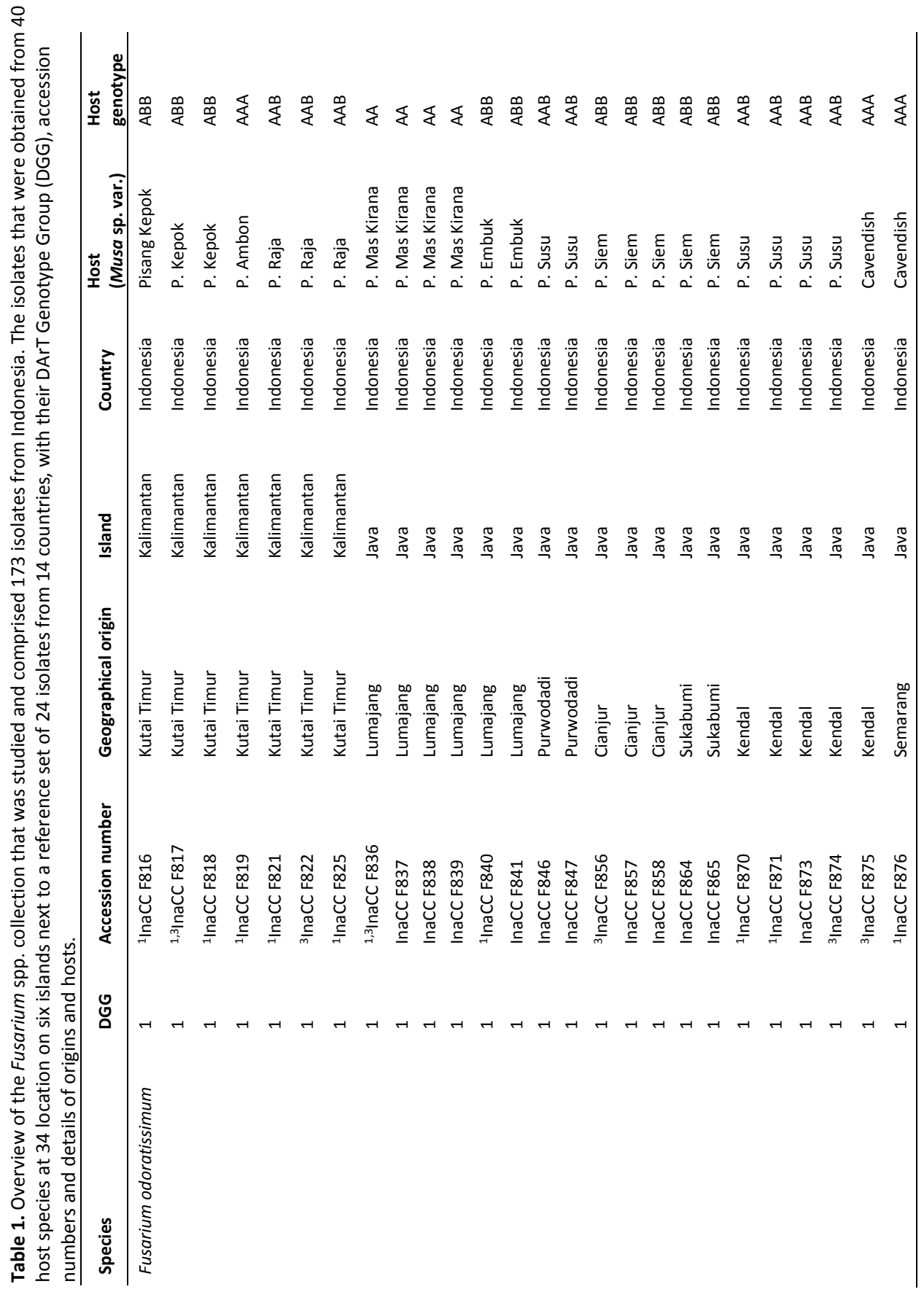




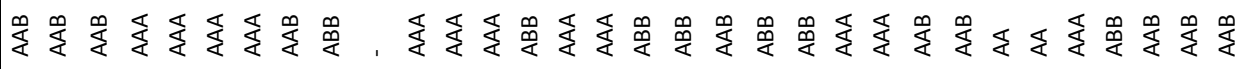

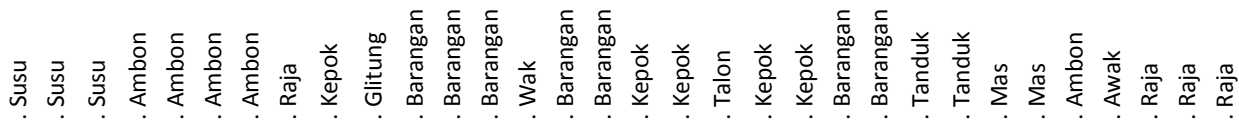

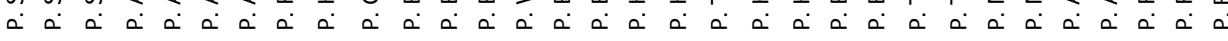

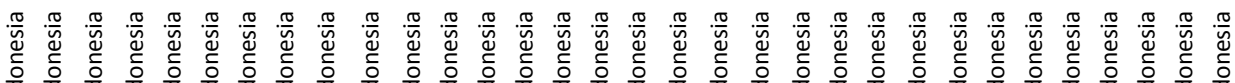

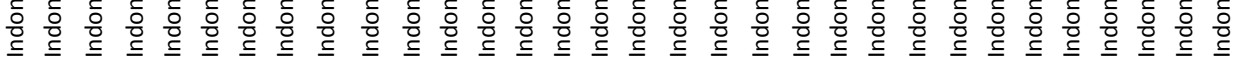

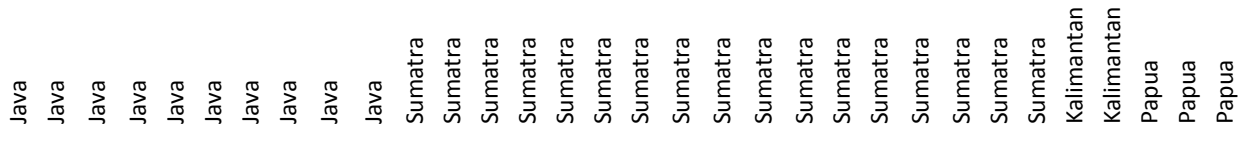

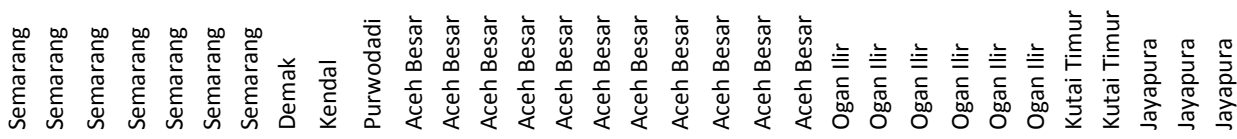

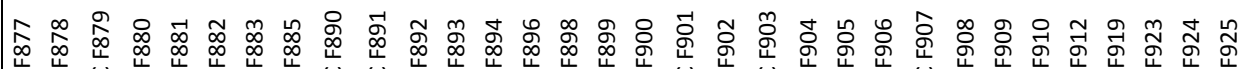

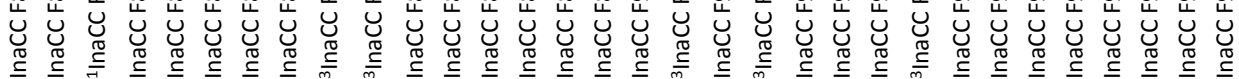




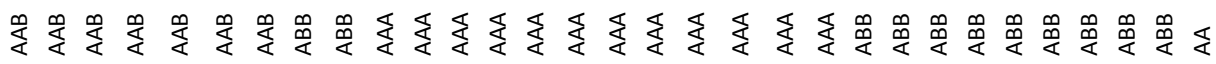

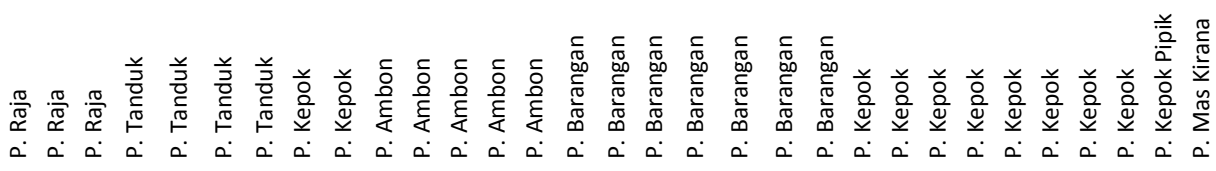

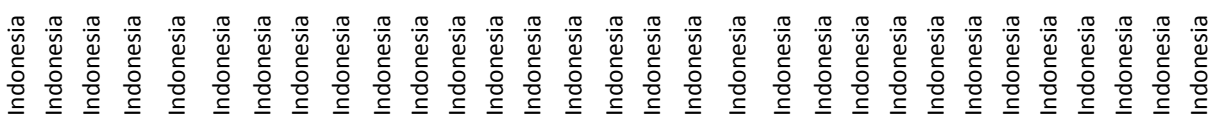

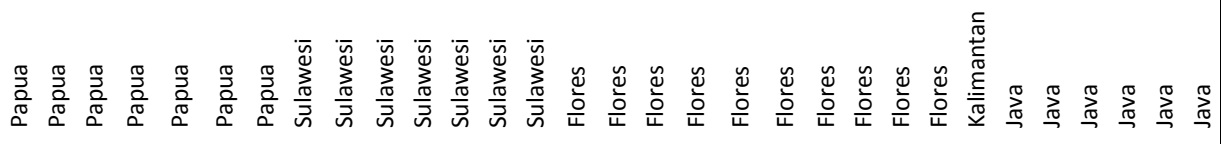

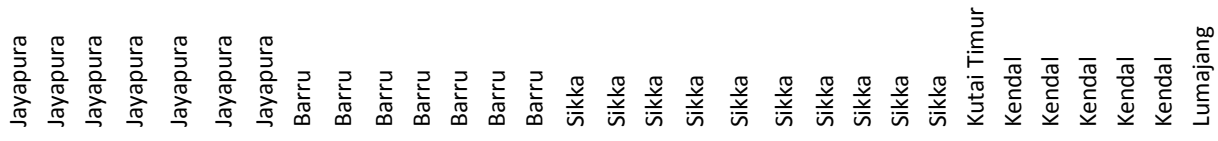

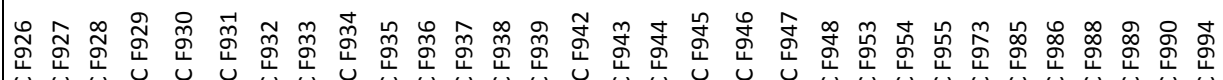

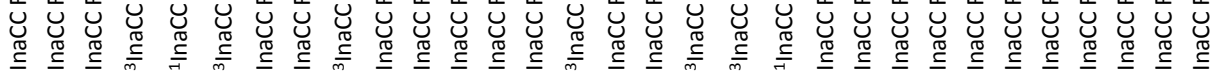




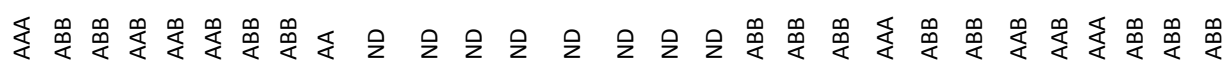

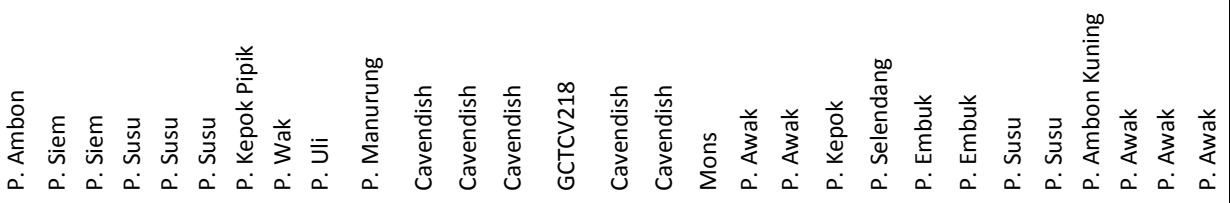

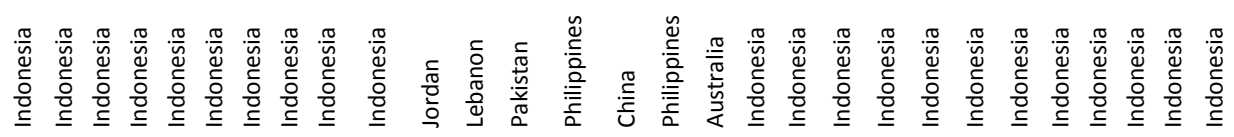

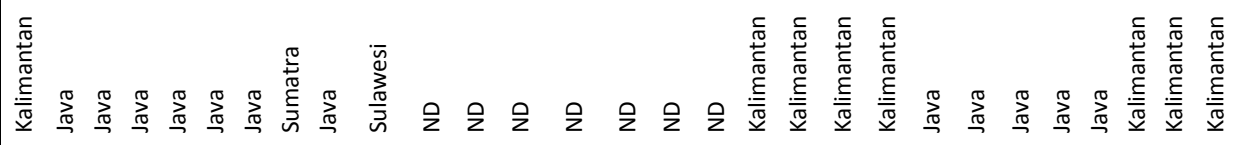

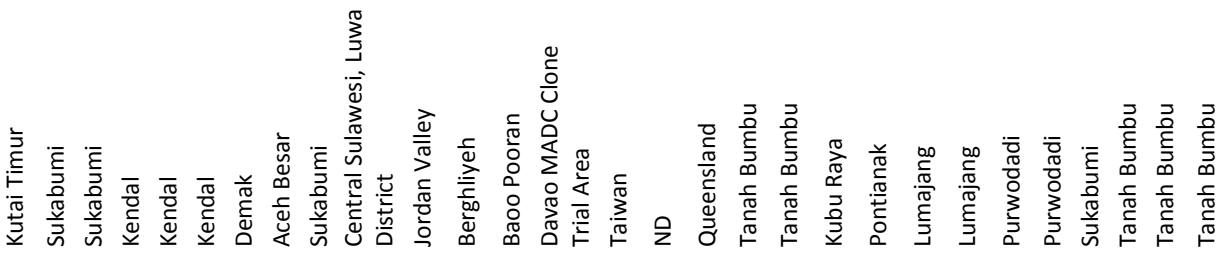

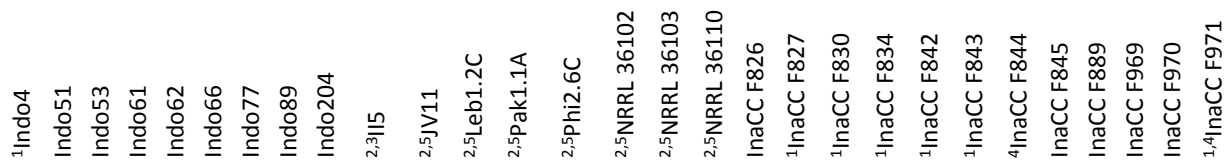




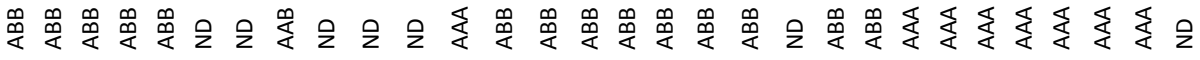

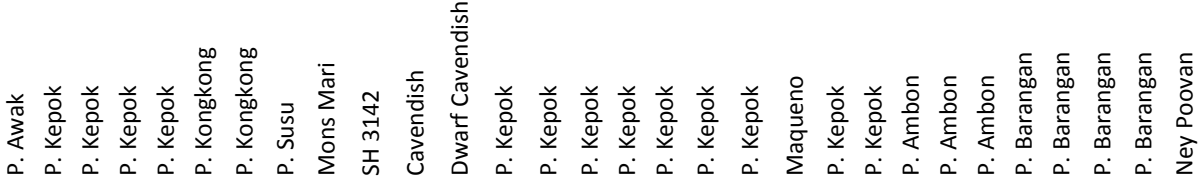

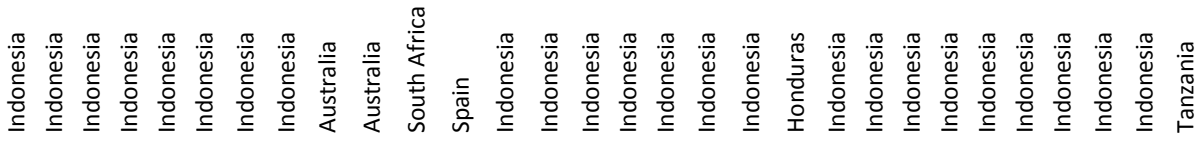

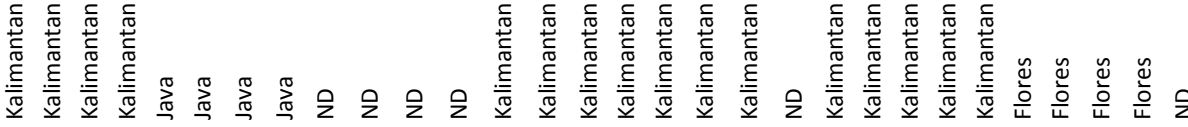

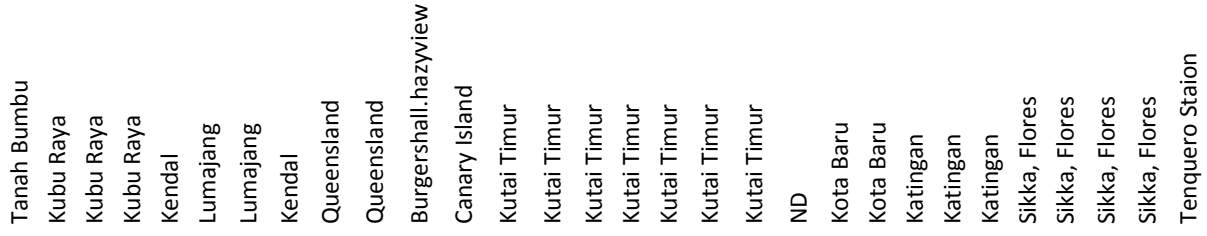

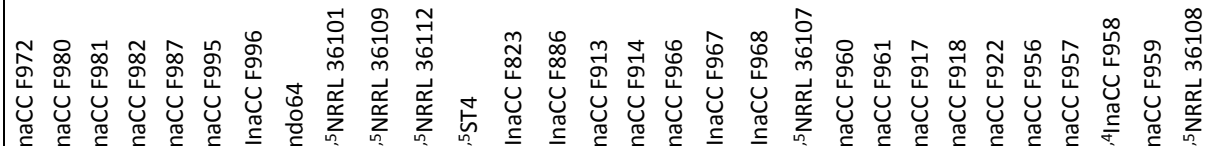

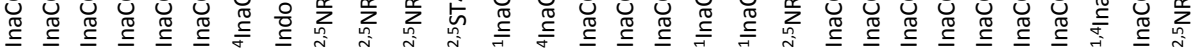

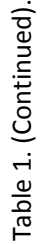

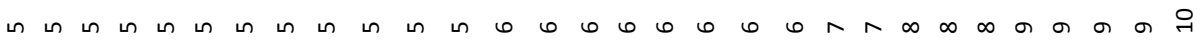




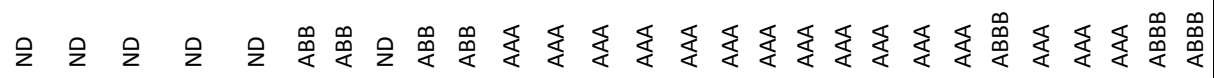

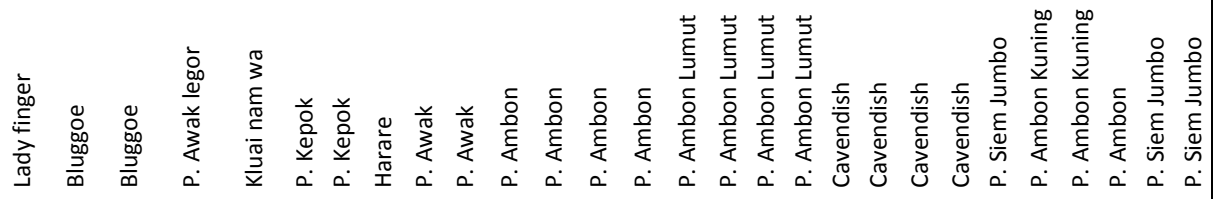

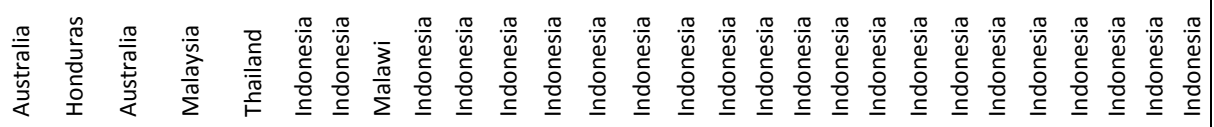

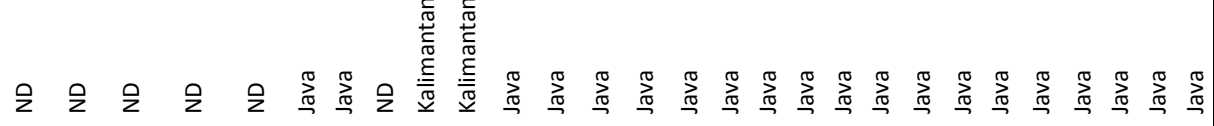

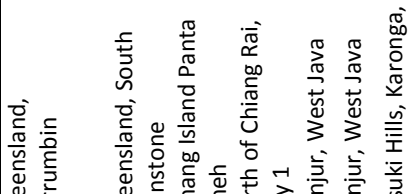

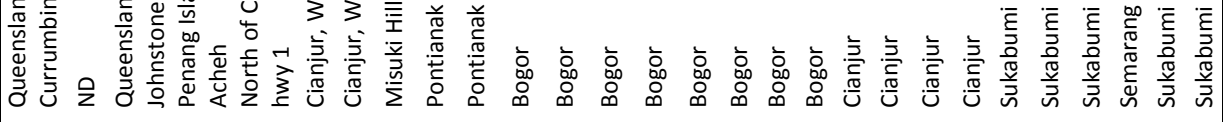

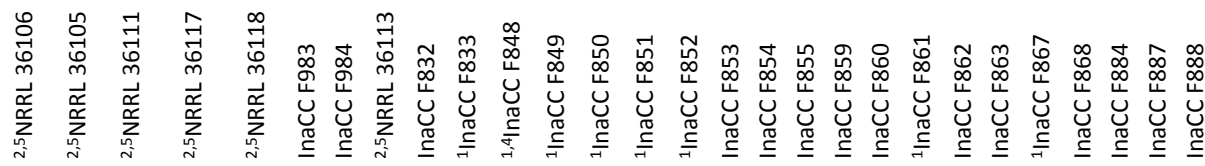

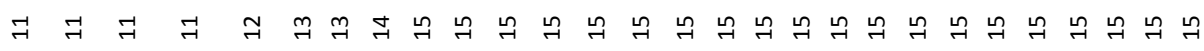

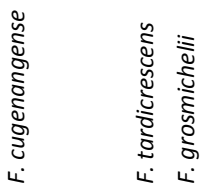




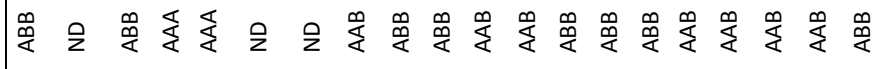

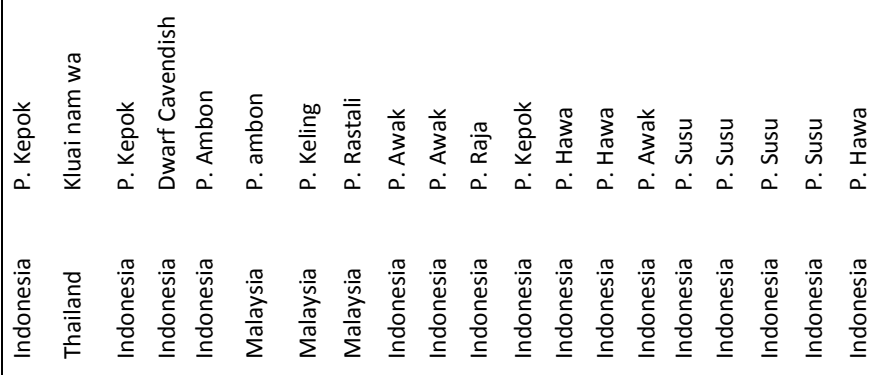

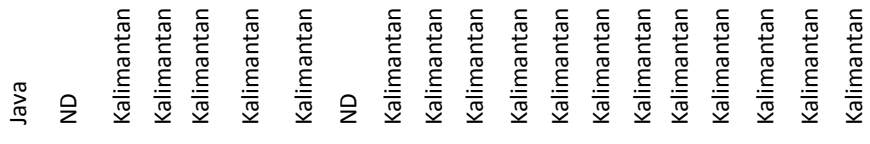

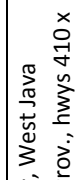




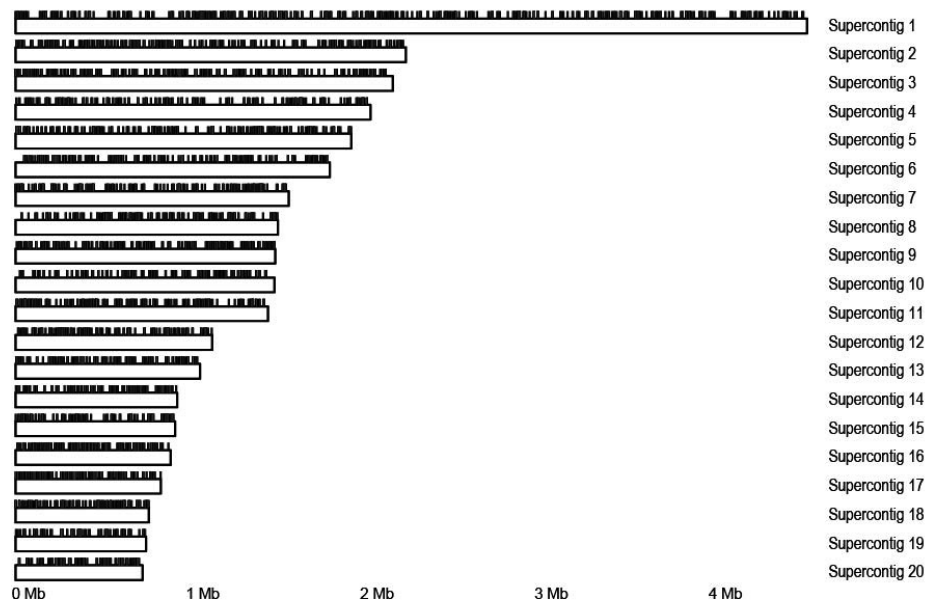

B
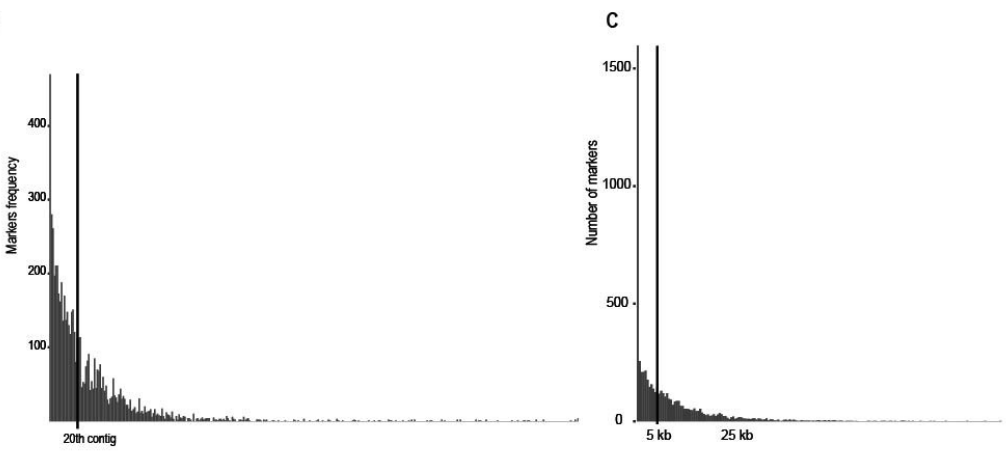

Fig. 2. Mapping of DArTSeq markers on the Fusarium odoratissimum II5 reference genome. A. Placement of DArTSeq markers on the longest 20 supercontigs. B. Number of markers per scaffold. C. Marker distances.

\section{Identification of DArT Genotypic Group (DGG) across Fusarium species isolated from banana}

To determine the genetic diversity among the isolates across species, we used all 13 150 polymorphic DArTseq markers to perform distance based hierarchical cluster analysis, which distributed the isolates over three of the five clades of the Fusarium oxysporum species complex (FOSC) (Fig. 3), hereafter denoted as Clades 1, 2, and 5 in concordance with the phylogeny of FOSC sensu O'Donnell et al. $(1998,2004)$ and Maryani et al. (2019). This encompasses 10 new phylogenetic species in the FOSC (Maryani et al. 2019; Table 1). All isolates were distributed over the three clades irrespective of their geographical origin and sampled host genotype (Fig. 3), demonstrating the high genetic diversity of Indonesian Fusarium spp. associated with Fusarium wilt in indigenous Indonesian bananas. 


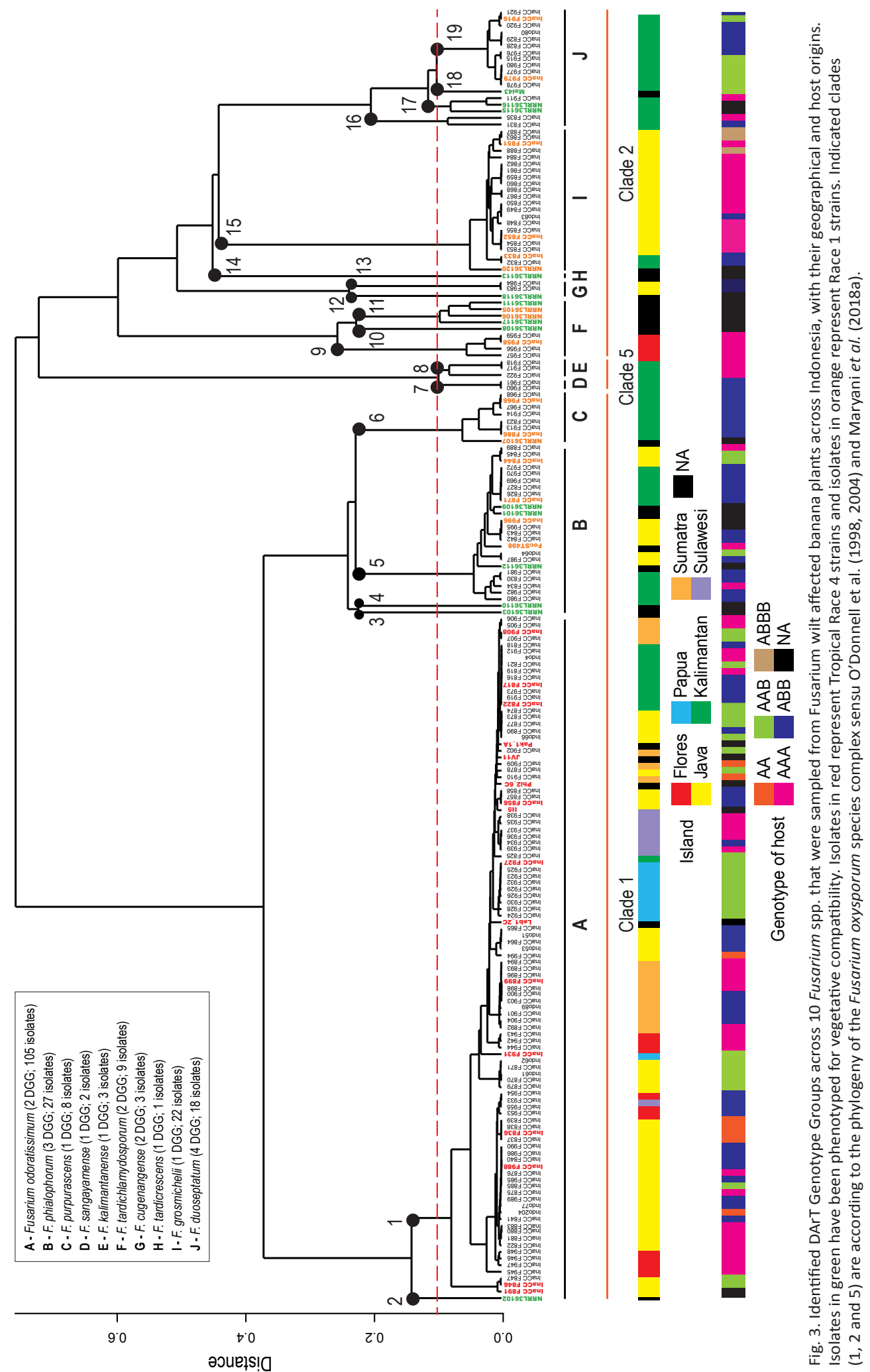


We identified 19 distinct DGGs along the tree (Fig. 3). The entire collection of Indonesian isolates is distributed over at least 10 of the 19 DGGs. Each Fusarium species contained a variable number of DGGs. The largest number of DGGs was observed in Fusarium duoseptatum with four DGGs, followed by F. phialophorum and F. tardichlamidosporum that have three DGGs and F. odoratissimum and F. cugenangense, which comprise two DGGs (Fig. 3). To assess the distribution of different DGGs in the known FOSC clades, we calculated the number of DGGs of each clade. Six DGGs were placed in Clade 1, including DGG1 which contained $55 \%$ of the Indonesian isolates. Eleven DGGs were identified in Clade 2, with the Indonesian isolates belonging to six DGGs and two DGGs were positioned in Clade 5.

Indonesian isolates in DGG1, which contains all previously known/described TR4 isolates, are highly aggressive to Cavendish banana (Table 1; Fig. 3; Maryani et al. 2019) and originated from geographically very diverse environments (i.e. different Indonesian islands) mostly on Java and Sumatra (Fig. 1). This DGG was isolated from diverse hosts comprising 37 different local banana varieties, including diploid and triploid genotypes (Fig. 3; Table 1).

Unlike TR4 isolates, Race 1 isolates, which are highly aggressive to the banana variety Gros Michel (Table 1; Fig. 3) were placed in six different DGGs. These DGGs clustered in Clade 1 and Clade 2 of FOSC, suggesting that Race 1 evolved independently multiple times. Race 1 isolates of $F$. duoseptatum, contained DGG16, DGG17, DGG18 and DGG19 and were shown to be geographically isolated. Isolates belonging to these DGGs, as well as the reference strains NRRL 36116 and NRRL 36115, were obtained only from Kalimantan. Similarly, DGG9 contained only isolates from Flores, and DGG13 contained isolates from Java. Interestingly, the majority of the host genotypes from which these isolates were sampled are triploid banana species (Fig. 3).

To determine whether the VCG-typed isolates are circumscribing the genotype differences in the Indonesian population, we included reference strains in the DArTSeq analysis. This set of isolates is known to capture the worldwide diversity of Fusarium spp. affecting banana (Ordóñez et al. 2015). Cluster analyses of DArTseq markers demonstrated that previously identified VCGs are discordant with genotypic differences among isolates, as one DGG might include more than one VCG, e.g. DGG5 and DGG11 contain four VCGs and DGG17 comprises two VCGs. However, seven DGGs contained only one VCG. Therefore, the VCG-typed reference isolates do not necessarily represent different genotypes as defined by distinct DGGs, and thus DArTSeq markers were unable to resolve the VCG classification in Fusarium species causing wilt on banana. 


\section{DISCUSSION}

Molecular techniques enable high-resolution diversity analyses amongst individuals of a given population (Milgroom 2015). An ideal molecular marker is independent, polymorphic, evenly distributed across the genome and is repeatable and unambiguous to score (Brown 1996, Schlötterer 2004). Here we demonstrate that DArTseq meets these criteria, and thus is a suitable tool to assess genetic variation amongst Fusarium spp. that are associated with banana plants affected by Fusarium wilt. Besides the number of generated markers $(>10,000)$, DArTSeq has the advantage - contrary to other existing molecular technologies - that it allows parallel instead of serial analyses of marker data (Wittenberg 2007). With a genome size of 46.5 MB (reference genome II5), our analysis of Fusarium spp. populations yielded a total of 13150 polymorphic markers. This number is considerably higher than in other banana pathogens, such as Pseudocercospora fijiensis, the Black Sigatoka pathogen of banana, with a genome size of $74 \mathrm{Mb}$ (Isaza et al. 2016), and from which a total 6586 DArTseq polymorphic markers were obtained (Chong 2016). DArT markers were also reported to provide good genome coverage in wheat and barley (Wenzl et al. 2004), Arabidopsis (Wittenberg et al. 2005), and the wheat pathogen Zymoseptoria tritici (previously Mycosphaerella graminicola) (Wittenberg et al. 2007, Kema et al. 2018). Thus, the excellent genome coverage of DArTseq markers is an important advantage for our diversity analyses, as the genetic diversity assessment is expected to be more robust and reliable.

Hierarchical clustering of the 196 isolates using DArTseq markers as a proxy of genetic relatedness resulted in the identification of 19 DGGs. Moreover, these analyses provided a good resolution of genomic variation (i.e. genotype) within the 10 species that were recently described by Maryani et al. (2019). Thus, we conclude that our current data strongly support the phylogenetic species concept of Fusarium spp. affecting banana. The current 19 DGGs significantly extend diversity and also the most extensive genotypic diversity of Fusarium spp. affecting banana reported to date. Bentley et al. (1998) reported six genotype groups discerned in a worldwide collection, which was based on DNA fingerprinting. The same collection was subsequently studied by Groenewald et al. (2006) who identified seven AFLP genotypic groups. Recently Mostert et al. (2017) distinguished just six RFLP groups in an Asian collection. Therefore, technology seems to determine the resolution of biological complexity and hence, genotyping-by-sequencing is currently an outstanding technology for highthroughput diversity analyses of Fusarium spp. associated with banana, particularly in the centre of diversity where sympatric speciation is expected (Stukenbrock et al. 2007, Foote 2018).

The majority of the Indonesian isolates was identified as TR4 and clustered in a single group (DGG1) F. odoratissimum. These isolates were recovered from many local banana varieties across the Indonesian archipelago. The higher incidence of TR4 isolates could be explained by the ability to infect a wide range of banana varieties, thus raising the chance to 
capture this specific race (Maryani et al. 2019). Therefore, TR4 strains are expected to dominate the Indonesian population, which corroborates with a previous report by Hermanto et al. (2009), who concluded that TR4 is well distributed across all the Indonesian islands, with the majority of isolates belonging to VCGs 01213/01216. However, this study comprised 100 isolates sampled from 14 banana accessions on 5 islands and was only based on VCGs. Here, DArTseq and cluster analyses clearly distinguish TR4 from the other sampled Fusarium spp. and assigns them unequivocally to F. odoratissimum (Maryani et al. 2019) showing that TR4 isolates share a similar genetic background. That observation that was also evident from phylogeographical analyses in the Greater Mekong area (Zheng et al. 2018) and recently developed diagnostics (Salacinas et al. 2018, Maryani et al. 2018). Additionally, our results confirm that Race 1 strains belong to different DGGs, recently recognized as several Fusarium species (Maryani et al. 2019). The diversity of Race 1 might be the result of its exposure to many different host varieties. A host population exerts selection pressure on pathogen populations, especially in different agroecosystems (Hansen 1987). Another factor which might contribute to Race 1 diversity is its soil dwelling nature that could facilitate horizontal gene transfer. It is well-known that Fusarium oxysporum undergoes horizontal gene transfer (Michielse \& Rep 2009, Ma et al. 2010, Van Dam et al. 2016) and recent effector studies suggested a similar phenomenon in banana infecting Fusarium strains (Czislowski et al. 2018). Thus, in a plantation with different banana varieties, there is a higher chance for horizontal gene transfer between pathogenic strains once they occupy the same niche (Vlaardingerbroek et al. 2016).

We demonstrate that VCG classification is not reflecting genetic diversity of Fusarium isolates affecting banana. Of the 20 VCGs that we included in the analyses (Ordóñez et al. 2015), only seven VCGs were placed in single DGGs, while the others comprised three to six VCGs. This is in accordance with Fourie et al. (2009) who demonstrated that more than one VCG could cluster within a single lineage. Therefore, VCG determination among isolates might reflect genetic similarities but hide genetic differences (Kistler 1997, Fourie et al. 2011). Our results also suggest that the evolutionary origin of Fusarium spp. affecting banana is driven by two processes. Firstly, our data corroborate the generally accepted hypothesis that Fusarium co-evolves with its banana host in South-East Asia (Stover 1962, Ploetz \& Pegg 1997, Buddenhagen 2007). Population studies of fungal pathogens have reported that co-evolution normally occurs in the centre origin of the hosts (Wyand \& Brown 2003, Stukenbrock \& McDonald 2008). For example, as Magnaporthe grisea displays higher diversity among Asian isolates where the host likely originated (Tharreau et al. 2009). Populations of the wheat pathogen Z. tritici were highly diverse in the fertile crescent where the origin and domestication of cereals occurred (Stukenbrock et al. 2007). Hence, our data representing the largest number of Fusarium spp. and genotypes to date, which were isolated from many local varieties in the centre origin of banana strongly suggest such a co-evolutionary process in the 
Indonesian archipelago. Secondly, O'Donnell et al. (1998) suggested that this pathogen also evolves independently in areas where the pathogen was introduced and geographic isolation has occurred. This is consistent with distinct DGGs for isolates outside Indonesia, e.g. Australia, Malawi, Taiwan, Tanzania and USA. Interestingly, one of the Race 1 lineages identified in Brazil (Dita et al. 2010) and another regional collection in Latin America (Ordóñez et al. 2018), were not present in the Indonesian Fusarium spp. identified in our study. This strongly suggests ongoing secondary or allopatric speciation of banana infecting Fusarium spp. outside Indonesia.

Given the ongoing epidemic of Fusarium wilt in banana (Maryani et al. 2019, Ordóñez et al. 2015, Zheng et al. 2018), we plan future studies to decipher the pathogenicity of this extensive Fusarium collection on a suite of different (indigenous) banana varieties. Combining these datasets will provide more insight in the evolutionary process of host adaptation in the centre of origin of banana and is crucial for any breeding program aiming for new and resilient banana varieties (Pillay \& Tenkouano 2011, Brown et al. 2017, http://www.promusa.org/INIBAP). Our study highlights the importance of analysing indigenous and international Fusarium populations to capture and unravel global diversity as a component towards sustainable banana production.

\section{ACKNOWLEDGMENTS}

This research was supported by KNAW-SPIN Project, "The Indonesian banana: Protecting a staple food from Panama disease collapse and exploiting its genetic diversity for discovery research". NM was also supported by DIKTI (Directorate General of Higher Education) Scholarship, Ministry of Research, Technology and Higher Education, Indonesia. MFS is supported by the Research Council Earth and Life Sciences (ALW) of The Netherlands Organization of Scientific Research (NWO). Banana research at WUR is supported by the Dutch Dioraphte Foundation endowed chair in Tropical Phytopathology of GHJK at the WUR-Laboratory of Phytopathology.

\section{REFERENCES}

Agrawal PK, Shrivastava R (2014). Molecular markers advances in biotechnology. In: Ravi I., Baunthiyal M., Jyoti S. (Eds.) Advances in Biotechnology (pp. 25-39). New Delhi: India.

Bentley S, Pegg K, Moore N, Davis R, et al. (1998). Genetic variation among vegetative compatibility groups of Fusarium oxysporum f. sp. cubense analyzed by DNA fingerprinting. Phytopathology 88(12): 1283-1293.

Bentley S, Pegg KG, Dale JL (1995). Genetic variation among a world-wide collection of isolates of Fusarium oxysporum f. sp. cubense analysed by RAPD-PCR fingerprinting. Mycological Research 99(11), 1378-1384.

Braithwaite K (2005). SRDC project BSS258-Assessing the impact that pathogen variation has on the sugarcane breeding program. http://elibrary.sugarresearch.com.au/.

Brown JKM (1996). The choice of molecular marker methods for population genetic studies of plant pathogens. New Phytologist 133(1), 183-195.

Brown A, Tumuhimbise R, Amah D, et al. (2017). Banana and Plantains (Musa spp.). In: Campos, H., Caligari, P. D. S. (Eds.) Genetic Improvement of Tropical Crops (pp. 219-240). SPringer: doi.org/10.1007/978-3-31959819-2_7.

Buddenhagen I (2007). Understanding strain diversity in Fusarium oxysporum f. sp. cubense and history of introduction of 'Tropical Race 4 ' to better manage banana production. Paper presented at the 
International Symposium on Recent Advances in Banana Crop Protection for Sustainable Production and Improved Livelihoods 828.

Chong APA (2016). The origin, versatility and distribution of azole fungicide resistance in the banana black Sigatoka pathogen Pseudocercospora fijiensis. PhD Thesis: Wageningen University, The Netherlands.

Cruz VMV, Kilian A, Dierig DA (2013). Development of DArT marker platforms and genetic diversity assessment of the US collection of the new oilseed crop Lesquerella and related species. PLoS One 8. doi: 10.1371/journal.pone.0064062.

Czislowski E, Fraser-Smith S, Zander M, et al. (2018). Investigation of the diversity of effector genes in the banana pathogen, Fusarium oxysporum f. sp. cubense, reveals evidence of horizontal gene transfer. Molecular plant pathology 19(5): 1155-1171.

Dita M, Waalwijk C, Buddenhagen I, et al. (2010). A molecular diagnostic for tropical race 4 of the banana fusarium wilt pathogen. Plant Pathology 59(2): 348-357.

Elshire RJ, Glaubitz JC, Sun Q, et al. (2011). A robust, simple Genotyping-by-Sequencing (GBS) Approach for high diversity species. PLOS ONE 6(5): e19379. doi:10.1371/journal.pone.0019379

Fourie G, Steenkamp ET, Gordon T, et al. (2009). Evolutionary relationships among the Fusarium oxysporum $\mathrm{f}$. sp. cubense vegetative compatibility groups. Applied and environmental microbiology 75(14): 4770-4781.

Foote AD (2018). Sympatric speciation in the genomic era. Trends in Ecology \& Evolution 33(2): https://doi.org/10.1016/j.tree.2017.11.003.

Fourie G, Steenkamp, Ploetz RC, et al. (2011). Current status of the taxonomic position of Fusarium oxysporum formae specialis cubense within the Fusarium oxysporum complex. Infection, Genetics and Evolution 11: 533-542.

Groenewald S, Van Den Berg N, Marasas WFO, et al. (2006). The application of high-throughput AFLP's in assessing genetic diversity in Fusarium oxysporum f. sp. cubense. Mycological Research 110(3): $297-305$.

Hansen EM (1987). Speciation in plant pathogenic fungi: the influence of agricultural practice. Canadian Journal Plant Pathology 9(3): 403-410.

Hermanto C, Sutanto A, Edison H, et al. (2009). Incidence and distribution of Fusarium wilt disease of banana in Indonesia. Paper presented at the International ISHS-ProMusa Symposium on Global Perspectives on Asian Challenges 897.

Isaza REA, Diaz-Trujillo C, Dhillon B, et al. (2016). Combating a global threat to a clonal crop: banana black Sigatoka pathogen Pseudocercospora fijiensis (synonym Mycosphaerella fijiensis) genomes reveal clues for disease control. PLoS genetics 12(8): e1005876.

Jaccoud D, Peng K, Feinstein D, et al. (2001). Diversity Arrays: a solid state technology for sequence information independent genotyping. Nucleic Acids Research 29(4): e25.doi: 10.1093/nar/29.4.e25.

Kema GHJ, Mizardi Gohari A, Aouini L, et al. (2018). Stress and sexual reproduction affect the dynamics of the wheat pathogen effector AvrStb6 and strobilurin resistance. Nature Genetics, https://doi.org/10.1038/s41588-018-0052-9.

Kistler HC (1997). Genetic Diversity in the Plant-Pathogenic Fungus Fusarium oxysporum. Phytopathology 87(4): 474-479.

Koenig R, Ploetz RC, Kistler H (1997). Fusarium oxysporum f. sp. cubense consists of a small number of divergent and globally distributed clonal lineages. Phytopathology 87(9), 915-923.

Ma L, Van Der Does HC, Borkovich KA, et al. (2010). Comparative genomics reveals mobile pathogenicity chromosomes in Fusarium. Nature 464(7287): 367-373.

Maryani N, Lombard L, Poerba YS, et al. (2019). Phylogeny and genetic diversity of the banana Fusarium wilt pathogen Fusarium oxysporum f. sp. cubense in the Indonesian centre of origin. Studies in Mycology 92: 155-194. https://doi.org/10.1016/j.simyco.2018.06.003.

Maryani N, Ahmad F, Keizer LCP, et al. (2018). Pathogenic diversity of Indonesian Fusarium wilt pathogens in wild and cultivated bananas. In submission

Metzker ML (2010). Sequencing technologies - the next generation. Nature review, doi:10.1038/nrg2626.

Michielse CB, Rep M (2009). Pathogen profile update: Fusarium oxysporum. Molecular Plant Pathology 10(3): 311-324.

Milgroom MG (2015). Population Biology of Plant Pathogens: Genetics, Ecology, and Evolution. Minnesota: The American Phytopathological Society press, USA.

Moore N, Pegg K, Allen R, et al. (1993). Vegetative compatibility and distribution of Fusarium oxysporum f. sp. cubense in Australia. Animal Production Science 33(6): 797-802.

Morgulis A, Coulouris G, Raytselis $Y$, et al. (2008). Database indexing for production MegaBLAST searches. Bioinformatics 24(16): 1757-1764. 
Mostert D, Molina A, Daniells J, et al. (2017). The distribution and host range of the banana Fusarium wilt fungus, Fusarium oxysporum f. sp. cubense, in Asia. PloS one 12(7): e0181630.

Nasution RE (1990). A taxonomic study of the species Musa acuminata Colla with its Intraspesific taxa in Indonesia. Ph.D dissertation: Tokyo University of Agriculture, Japan.

O'Donnell K, Kistler HC, Cigelnik E, et al. (1998). Multiple evolutionary origins of the fungus causing Panama disease of banana: Concordant evidence from nuclear and mitochondrial gene genealogies. Proceedings of the National Academy of Sciences 95(5): 2044-2049.

O'Donnell K, Sutton DA, Rinaldi MG, et al. (2004). Genetic diversity of human pathogenic members of the Fusarium oxysporum complex inferred from multilocus DNA sequence data and amplified fragment length polymorphism analyses: evidence for the recent dispersion of a geographically widespread clonal lineage and nosocomial origin. Journal of Clinical Microbiology 42(11): 5109-5120.

O'Donnell K, Ward TJ, Robert VARG, et al. (2015). DNA sequence-based identification of Fusarium: Current status and future directions. Phytoparasitica 43(5): 583-595.

Ordóñez N, Seidl MF, Waalwijk C, et al. (2015). Worse comes to worst: bananas and Panama disease-when plant and pathogen clones meet. PLoS Pathogens 11(11): e1005197.

Ordóñez N (2018). A global genetic diversity analysis of Fusarium oxysporum f. sp. cubense, the Panama disease pathogen of banana. Ph.D dissertation. Experimental Plant Sciences, Wageningen University, The Netherlands.

Perrier X, De Langhe E, Donohue M, et al. (2011). Multidisciplinary perspectives on banana (Musa spp.) domestication. Proceedings of the National Academy of Sciences of the United States of America 108(28): 11311-11318.

Pillay M, Tenkouano A. (2011). Banana breeding: Progress and challenges. Boca Raton, FL, CRC Press.

Ploetz RC (1990). Variability in Fusarium oxysporum f. sp. cubense. Canadian Journal of Botany 68(6): 1357-1363.

Ploetz RC, Pegg K (1997). Fusarium wilt of banana and Wallace's line: Was the disease originally restricted to his Indo-Malayan region? Australasian Plant Pathology 26(4): 239-249.

Ploetz RC (2006). Panama disease, an old nemesis rears its ugly head: part 2, the cavendish era and beyond. Plant Health Progress, 1-17. doi:10.1094/PHP-2006-0308-01-RV.

Ploetz RC, Kema GHJ, Ma LJ (2015). Impact of diseases on export and smallholder production of banana. Annual Review of Phytopathology, 53, 269-288.

Ploetz RC (2015). Management of Fusarium wilt of banana: A review with special reference to tropical race 4. Crop Protection, 73, 7-15.

Puhalla JE (1985). Classification of strains of Fusarium oxysporum on the basis of vegetative compatibility. Canadian Journal of Botany 63(2): 179-183.

Salacinas M, Ordóñez N, Mendes O, et al. (2018). A loop-mediated isothermal amplification assay based on unique markers derived from genotyping-by-sequencing data for rapid in-plant diagnosis of Fusarium oxysporum f. sp. cubense tropical race 4 in banana. Submitted

Schlötterer C (2004). The evolution of molecular markers - just a matter of fashion? Nature Reviews 5:63-69.

Simmonds N (1962). The Evolution of Bananas. London: Longman Itd.

Snyder WC, Hansen HN (1940). The Species Concept in Fusarium. American Journal of Botany 27(2): 64-67.

Stover R, Waite B (1960). Studies on Fusarium wilt of bananas: V. Pathogenicity and distribution of Fusarium oxysporum $f$. cubense Races 1 and 2. Canadian Journal of Botany 38(1): 51-61.

Stover RH (1962). Fusarial wilt (Panama Disease) of bananas and other Musa species. Oxford University press, Oxford, UK.

Stukenbrock EH, Banke S, Javan-Nikkhah M, et al. (2007). Origin and domestication of the fungal wheat pathogen Mycosphaerella graminicola via sympatric speciation. Molecular Biology and Evolution 24(2): 398-411.

Stukenbrock EH, McDonald BA (2008). The origins of plant pathogens in agro-ecosystems. Annual Review Phytopathology 46: 75-100.

Su Hj, Hwang S, Ko W (1986). Fusarial wilt of Cavendish bananas in Taiwan. Plant Disease 70(9): 814-818.

Tharreau D, Fudal I, Andriantsimialona D, et al. (2009). World population structure and migration of the rice blast fungus, Magnaporthe oryzae. In: Wang, G.L., Valent, B. (Eds.) Advances in genetics, genomics and control of rice blast disease (pp.209-215). Springer DOI 10.1007/978-1-4020-9500-9.

Van Dam P, Fokkens L, Schmidt SM, et al. (2016). Effector profiles distinguish formae speciales of Fusarium oxysporum. Environmental Microbiology 18(11): 4087-4102.

Vlaardingerbroek I, Beerens B, Rose L, et al. (2016). Exchange of core chromosomes and horizontal transfer of lineage-specific chromosomes in Fusarium oxysporum. Environmental Microbiology 18(11): 3702-3713. 
Wenzl P, Carling J, Kudrna D, et al. (2004). Diversity Arrays Technology (DArT) for whole-genome profiling of barley. Proceedings of the National Academy of Sciences of the United States of America 101(26): 99159920.

Wittenberg AH (2007). Genetic mapping using the diversity arrays technology (DArT): application and validation using the whole-genome sequences of Arabidopsis thaliana and the fungal wheat pathogen Mycosphaerella graminicola. Ph. D Thesis: Wageningen University, The Netherlands.

Wyand RA, Brown JKM (2003). Genetic and forma specialis diversity in Blumeria graminis of cereals and its implications for host-pathogen co-evolution. Molecular Plant Pathology 4(3): 187-198.

Yin T, Cook D, Lawrence M (2012). ggbio: an R package for extending the grammar of graphics for genomic data. Genome Biology 13(8): R77.doi: 10.1186/gb-2012-13-8-r77.

Zheng, SJ, García-Bastidas FA, Li X, et al. (2018). New geographical insights of the latest expansion of Fusarium oxysporum f.sp. cubense Tropical Race 4 into the Greater Mekong Subregion. Frontiers in Plant Science 9 (457): 10.3389/fpls.2018.00457. 



\title{
Chapter 4
}

\section{Pathogenic diversity of Indonesian Fusarium wilt pathogens in wild and cultivated bananas}

\author{
Nani Maryani ${ }^{1,2,3}$, Fajarudin Ahmad', Paul L.C. Keizer', Pedro W. Crous', \\ and Gerrit H.J. Kema ${ }^{1,2}$
}

\footnotetext{
'Biointeractions and Plant Health, Wageningen Plant Research, Wageningen University and Research, Wageningen, The Netherlands; ${ }^{2}$ Laboratory of Phytopathology, Wageningen University and Research, Wageningen, The Netherlands; ${ }^{3}$ Biology Education, Faculty of Education, Universitas Sultan Ageng Tirtayasa (UNTIRTA), Banten, Indonesia; ${ }^{4}$ Westerdijk Fungal Biodiversity Institute, Utrecht, The Netherlands
} 


\begin{abstract}
Fusarium wilt of banana is caused by a group of Fusarium species in the Fusarium oxysporum species complex (FOSC). Recent diversity analyses on an extensive Fusarium collection from the Indonesian archipelago, which is the centre of diversity of banana and hence from coevolving Fusarium species, revealed eleven new Fusarium species that were affecting banana. Here we assess the pathogenic variation of 78 isolates from these species on the four banana accessions Pisang Ambon Hijau (Musa acuminata, AAA, Cavendish subgroup 'Grand Naine'), Pisang Ambon Kuning (Musa acuminata, AAA, Gros Michel subgroup 'Gros Michel'), Musa acuminata ssp. malaccensis 'Pahang', and Pisang Rejang (Musa acuminata, AA, Sucrier subgroup 'Rose'). All isolates that are pathogenic on Grand Naine and Gros Michel belong to Fusarium odoratissimum, previously known as Tropical Race 4 (TR4), which also showed quantitative variation for aggressiveness. Isolates pathogenic on Gros Michel are more genetically diverse and belong to six Fusarium species. Taken together, these data showed significant isolate - banana accession interactions, indicating an underlying gene-for-gene (GFG) system. We also demonstrate the overall resistance of Musa acuminata ssp. malaccensis (Pahang) and Pisang Rejang to this suite of Fusarium species and even to the most aggressive TR4 isolates. Our study provides a first insight in pathogenic variation among indigenous Fusarium species to endemic banana accessions in Indonesia. The wide resistance in M. acuminata ssp. malaccensis and Pisang Rejang is promising for breeding programs aiming for new and resistant banana varieties.
\end{abstract}

Key words: Banana, Fusarium odoratissimum, phenotyping, Tropical Race 4, virulence 


\section{INTRODUCTION}

Fungal plant pathogens are among the major constrains of global food production (Gurr et al. 2011). Particularly since the emergence of fungal strains that are resistant to fungicides, which threaten food security and urges for innovations and integrated management to control their spread (Fisher et al. 2018). This applies to the commonly known cereal staple foods, but also to crops such as banana. Banana is the number one fruit commodity in the world and also a staple food in many (sub)tropical countries (http://faostat.org/). Therefore, sustaining banana production is important to supply domestic and international markets to also support the livelihood of millions of smallholder farmers. However, banana is threatened by Fusarium wilt or Panama disease, one of the most devastating diseases (Simmonds 1962), that recently re-emerged in this crop (Ordóñez et al. 2015).

The disease is caused by a suite of soil-borne fungi belongs to the Fusarium oxysporum species complex (FOSC), which has been reported in all banana producing areas across the globe (Ploetz 1994, Ordóñez et al. 2015, Maryani et al. 2019). The decline of global banana production as a result of the disease significantly impacts food and employment security (http://www.fao.org/world-banana-forum/). The previous epidemic in the late 1960's was largely confined to Latin America where it destroyed hundreds of Gros Michel plantations, and is considered as one of the most destructive botanical epidemics in history (Ploetz 2015). The banana industry was eventually saved by planting Cavendish varieties that are resistant to the so-called Race 1, which effectively comprises a group of genetically diverse species with pathogenicity towards Gros Michel (Ordóñez et al. 2015, Maryani et al. 2019). However, already in the 1960s another genotype, colloquially named Tropical Race 4 (TR4), was found to kill Cavendish plants in Taiwan (Su et al. 1986). Since then, this virulent strain has disseminated regionally, internationally and even intercontinentally (Moore et al. 1991, Hermanto et al. 2009, Ordóñez et al. 2015, Zheng et al. 2018), and therefore there have been urgent calls for more attention and effort to study this pathogen and prevent further dissemination (Kema \& Weise, 2013).

Studies on the diversity of fungi causing Fusarium wilt in the banana suggest that these co-evolved with the host in the centre of origin of banana in South-East Asia (Simmonds 1962, O'Donnell et al. 1998, Groenewald et al. 2006, Maryani et al. 2019). One of the earliest reports of Fusarium wilt on banana was in 1916, in a banana plantation in Java which from there disseminated to the African continent via Madagascar and to the American continent through Suriname (Simmonds 1962, Ploetz \& Pegg 1997, Buddenhagen 2007). This was recently supported by Maryani et al. (2019) who showed that eight out of nine globally disseminated Fusarium species are indigenous in Indonesia. Therefore, Indonesia is a key area for the discovery of new sources of resistance and for pathogen population diversity analyses in order to better understand the banana - Fusarium pathosystem. 
Many molecular studies report genetic diversity of Fusarium spp. affecting banana (Fourie et al. 2009, O’Donnell et al. 1998, Mostert et al. 2017). Maryani et al. (2019) recently identified eleven phylogenetic species in the FOSC isolated from local banana varieties suffered with Fusarium wilt in Indonesia. Using a genotyping-by-sequencing approach each of these species was shown to contain extensive genotypic diversity across Indonesia (Maryani et al. 2018). However, the relationship with pathogenicity towards different banana varieties is unknown. Traditionally three physiological races are recognized in the banana - Fusarium pathosystem. Race 1 is pathogenic on Gros Michel (AAA) and Silk (AAB) varieties and Race 2 is pathogenic on Bluggoe (ABB) (Stover \& Waite 1960). Race 4 is pathogenic on Cavendish (AAA) varieties as well as on a wide range of local banana varieties in the tropics and was subdivided in the aggressive Tropical Race 4 (TR4) (Ploetz 1994, Gerlach et al. 2000) and subtropical Race 4 (ST4) that affects Cavendish merely under abiotic stresses (Ploetz 2005).

Traditionally, race identifications and nomenclature in fungal pathogens are based on large interaction data sets, which were later unravelled by the identification of resistance and (a)virulence genes that frequently comply with gene-for-gene (GFG) or inverse GFG systems (Person 1955, Friesen et al. 2008, Kema et al. 2018). However, the genetic basis of the race concept in the banana - Fusarium pathosystem is poorly understood. The first gene for resistance to Fusarium wilt in banana was only recently identified (Dale et al. 2017), and the understanding of pathogenicity is in its initial stages (Guo et al. 2015, Czislowski et al. 2018). Alternative systems based on the level of aggressiveness on a set of host cultivars which some consider likely for the banana - Fusarium pathosystem (Stover \& Buddenhagen 1986, Larkin 1990, Correll 1991) are in our opinion largely due to the lack of (genetic) data and poor phenotyping protocols under variable conditions. Hence, the race concept of Fusarium wilt in banana is unclear and lacks accuracy. Here, we initiate a phenotyping program by screening many isolates of different Fusarium species causing Fusarium wilt on banana (Maryani et al. 2018) on a few Indonesian banana accessions. The data show both qualitative and quantitative variation for pathogenicity and provide a first step towards unveiling the genetic basis of the banana - Fusarium wilt pathosystem.

\section{MATERIALS AND METHODS}

\section{Banana plants}

Four banana accessions, comprising the wild diploid ancestor Musa acuminata ssp. malaccensis 'Pahang' and the cultivated Indonesian varieties Pisang Rejang (Musa acuminata, AA, Sucrier subgroup 'Rose'), Pisang Ambon Kuning (Musa acuminata, AAA, Gros Michel subgroup 'Gros Michel') and Pisang Ambon Hijau (Musa acuminata, AAA, Cavendish subgroup 'Grand Naine') were used in the phenotyping assays (Table 1; Fig. 1). All accessions were received as in vitro plantlets and were potted in Swedish sphagnum soil (peat $5 \%$, grinding clay granules $41 \%$, garden peat $5 \%$, beam structure $4 \%$, steamed compost $33 \%$ and PG-Mix 
15-10-20 $12 \%)$ for a two-weeks acclimatization under $100 \%$ relative humidity at $25^{\circ} \mathrm{C}$, Henceforward, plants were maintained for two to three months under greenhouse conditions (constant day temperature of $25^{\circ} \mathrm{C}$, night temperature of $23^{\circ} \mathrm{C}$, ambient light until max. $16 \mathrm{~h}$, and relative humidity of $\geq 75 \%$ ) before they were used in phenotyping assays.

\section{Isolates and pathogenicity assays}

A collection of Fusarium species causing wilt on banana was obtained from symptomatic local banana varieties across Indonesia between 2014-2015 (Maryani et al. 2019). Seventy-eight isolates were selected that represent the widest genetic diversity of Fusarium species in banana and include isolates from all sampled locations and hosts (Table 2, Maryani et al. 2019). Fusarium odoratissimum strain II5 and CNPMF.R1 were used as positive controls for TR4 and Race 1, respectively. Recently developed inoculum production and phenotyping assay protocols Garcia-Bastidas et al., (in prep.) were adopted with modifications. We added four infected maize kernels of each isolate to the potted banana plants in addition to the pouring inoculation method. After inoculation, plants were maintained in the same greenhouse with water/nutrients supplements twice per week during the eight weeks incubation period, after which the plants were scored for leaf chlorosis and then uprooted and dissected for internal corm evaluation.

Table 1. Banana varieties with details, synonym, genotype, origins, and source for pathogenicity test.

\begin{tabular}{|c|c|c|c|c|c|}
\hline Variety & Synonym & Code & Genotype & Origin & Source \\
\hline $\begin{array}{l}\text { Musa acuminata, AAA, Cavendish } \\
\text { subgroup 'Grand Naine' }\end{array}$ & Pisang Ambon Hijau & GN & AAA $(3 x)$ & - & $\begin{array}{l}\text { Rahan } \\
\text { Meristem, } \\
\text { Israel }\end{array}$ \\
\hline $\begin{array}{l}\text { Musa acuminata, AAA, Gros Michel } \\
\text { subgroup 'Gros Michel' }\end{array}$ & $\begin{array}{l}\text { Pisang Ambon } \\
\text { Kuning }\end{array}$ & GM & $\operatorname{AAA}(3 x)$ & - & $\begin{array}{l}\text { Corbana, } \\
\text { Costa Rica }\end{array}$ \\
\hline $\begin{array}{l}\text { Musa acuminata, AA, Sucrier subgroup } \\
\text { 'Rose' }\end{array}$ & Pisang Rejang & Rejang & $A A(2 x)$ & Indonesia & $\begin{array}{l}\text { ITC } \\
\text { Leuven }\end{array}$ \\
\hline $\begin{array}{l}\text { Musa acuminata ssp. malaccensis } \\
\text { 'Pahang' }\end{array}$ & - & Pahang & $A A(2 x)$ & Malaysia & $\begin{array}{l}\text { ITC } \\
\text { Leuven }\end{array}$ \\
\hline
\end{tabular}

\section{Experimental design and data analyses}

Experiments were conducted between 2015 and 2016 following a partially balanced incomplete design. Four experiments were performed (Table 3), using a selection of strains based on their phylogenies in a previous study (Maryani et al. 2019). Sixty-three isolates were assayed on Grand Naine, 23 isolates on Grand Naine and Gros Michel and 15 isolates were assayed on these cultivars as well as on the resistant accessions Pahang and Rejang. Finally, we investigated whether the $25 \mathrm{~F}$. odoratissimum TR4 isolates showed quantitative variation for aggressiveness towards Grand Naine (Table 3). In each experiment two disease parameters, corm discoloration (C) and foliar wilting (L), were scored following the aforementioned protocols with modification (Fig. 2 and Fig. 3). For data analyses we used the statistical package GENSTAT (VSN International 2015) for Restricted Maximum Likelihood 
analysis (REML) to estimate fixed and random variances in a Linear Mixed Model (LMM) of both parameters for each experiment, which allows for unbalanced data in the estimation of variance components and fixed effects in a multi-stratum ANOVA with correlated error term. Genetic variation for virulence among isolates of different Fusarium species was determined with the fixed model (Best Linear Unbiased Estimates, BLUE's) and random model (Best Linear Unbiased Predictions, BLUP's). Given the unbalanced occurrence of the isolates across experiments which results in different precision estimates for the pairwise comparisons, we use isolate and therefore also the isolate.cultivar interaction as a random term to obtain mean values. Correlations between the corm and leaf data were performed using pairwise comparisons. Fisher's protected Least Significant Difference (LSD) test was used to determine groups based on their pathogenicity with $F$. odoratissimum II5 and Grand Naine as references for isolates and hosts, respectively. The means were subjected to hierarchical cluster based on group averages that endorse analyses pathogenicity group in a previous study (Maryani et al. 2019). 


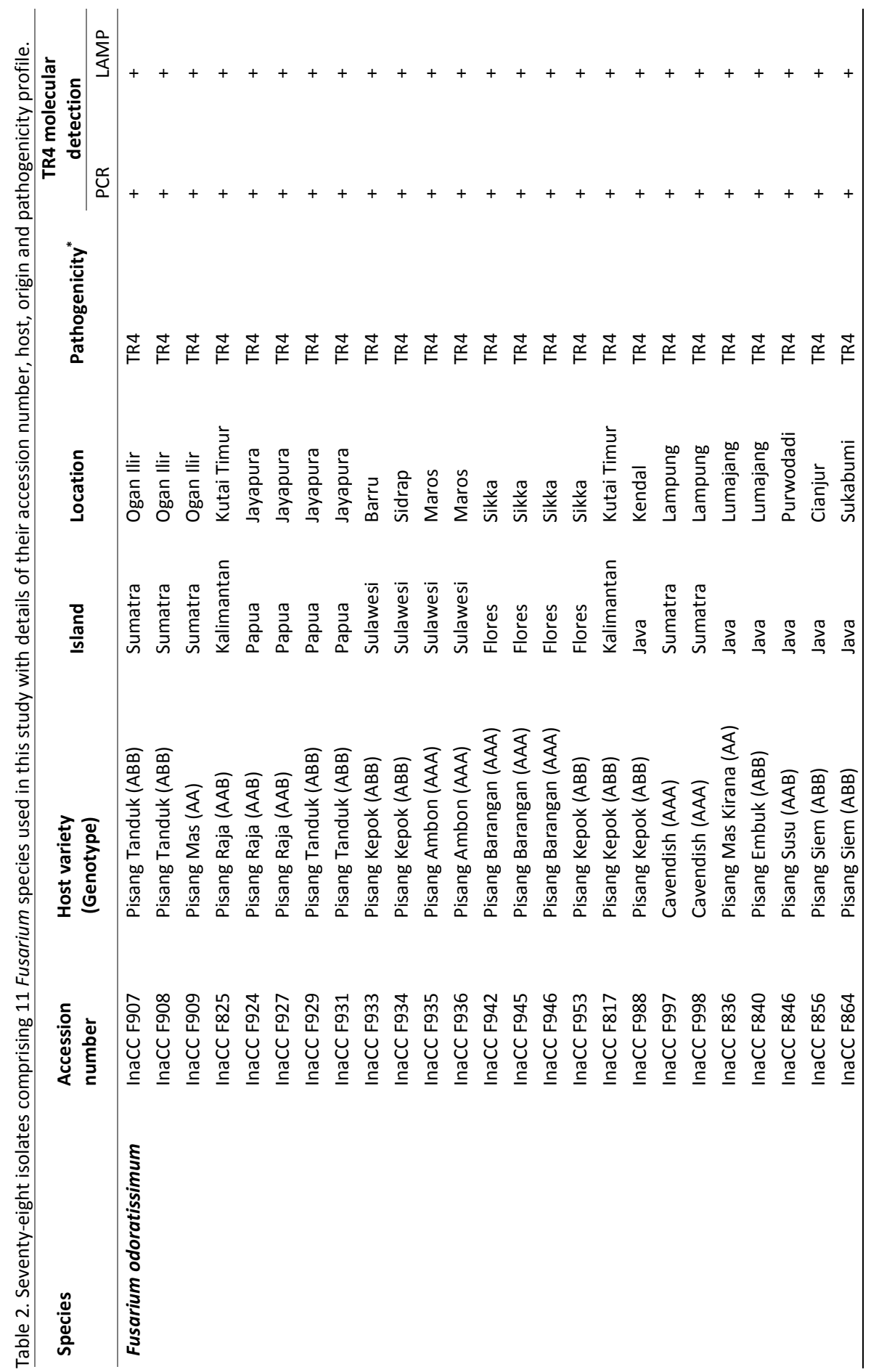




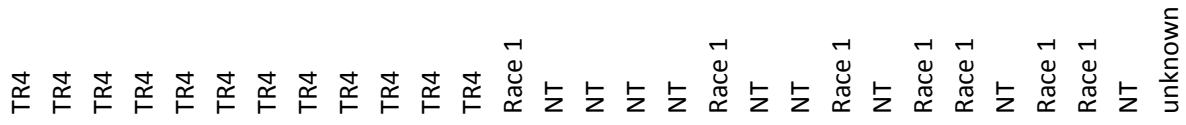

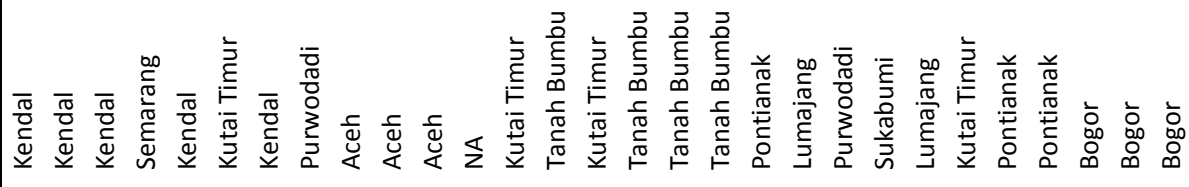

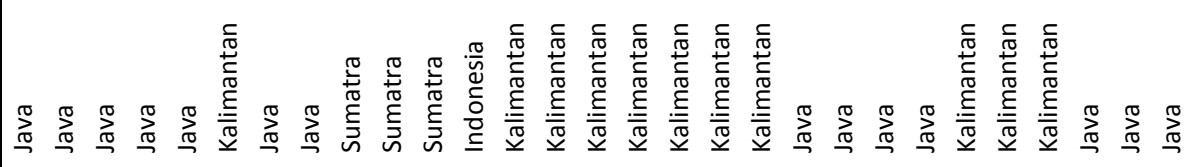

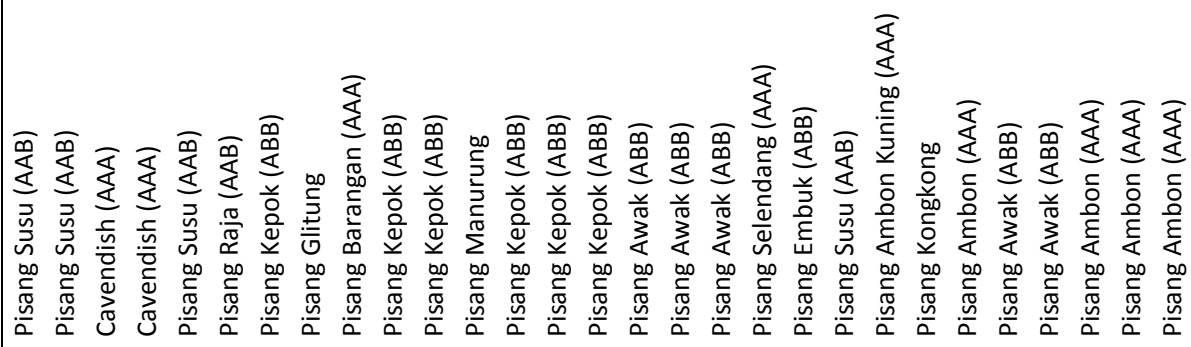

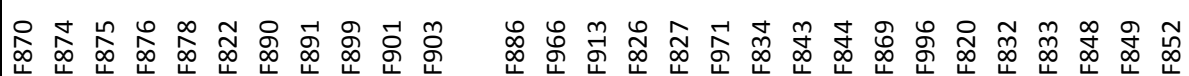

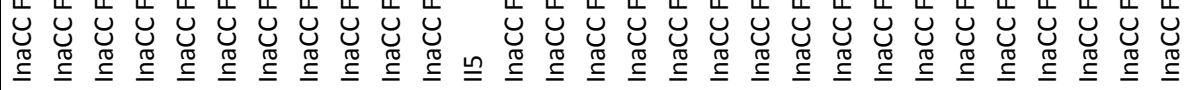




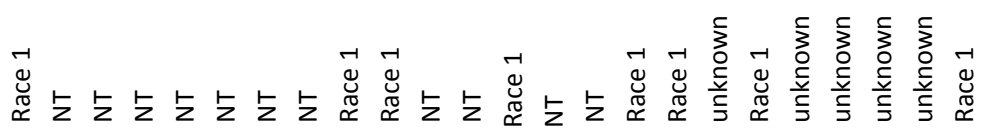

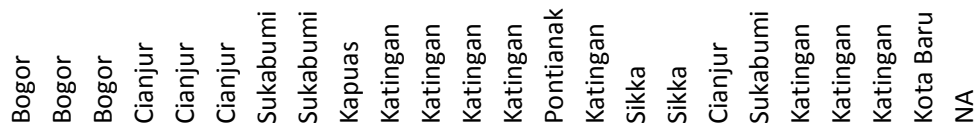

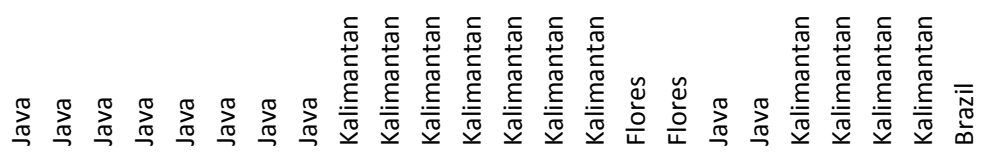

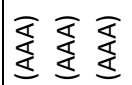

畄要

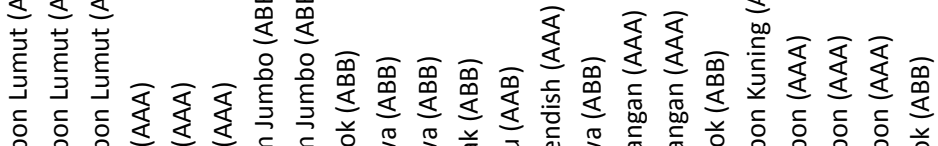

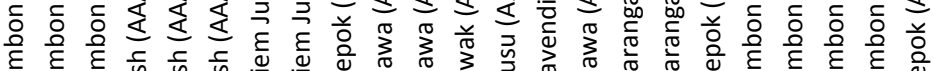

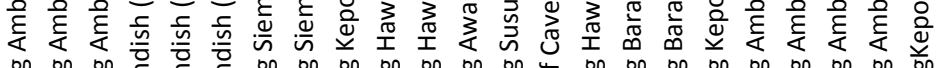

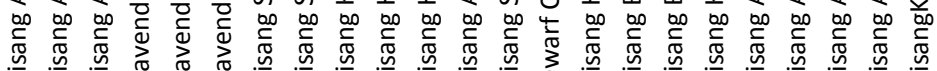

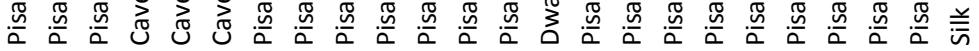

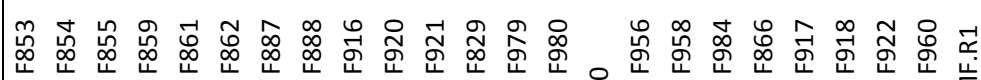
岁荡

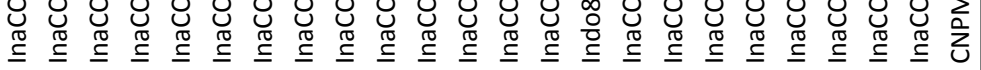
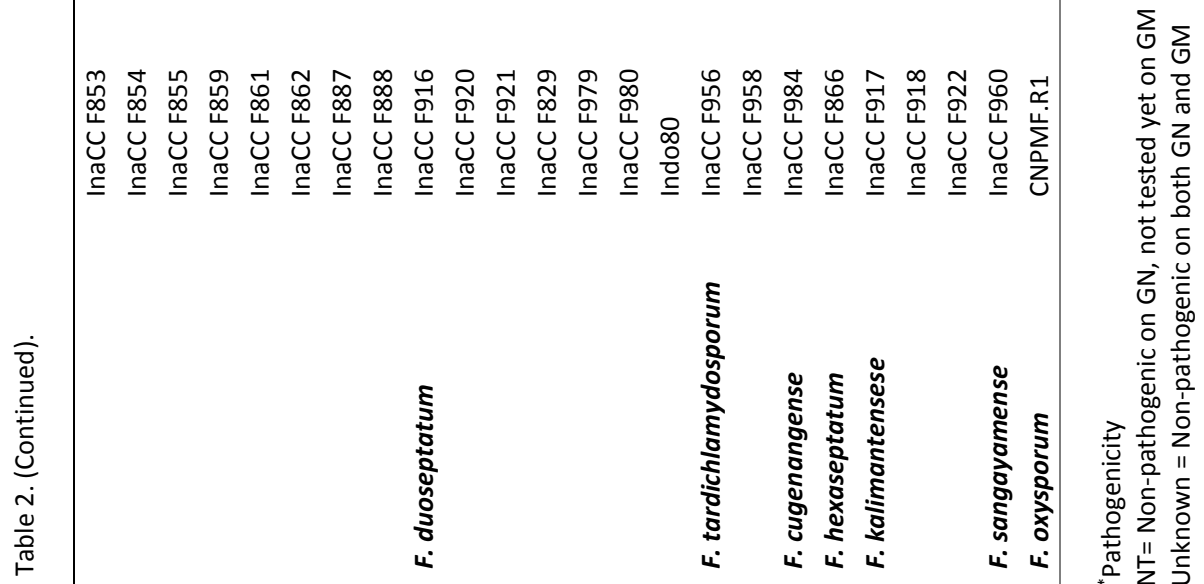
Pathogenic diversity of Indonesian Fusarium wilt pathogens
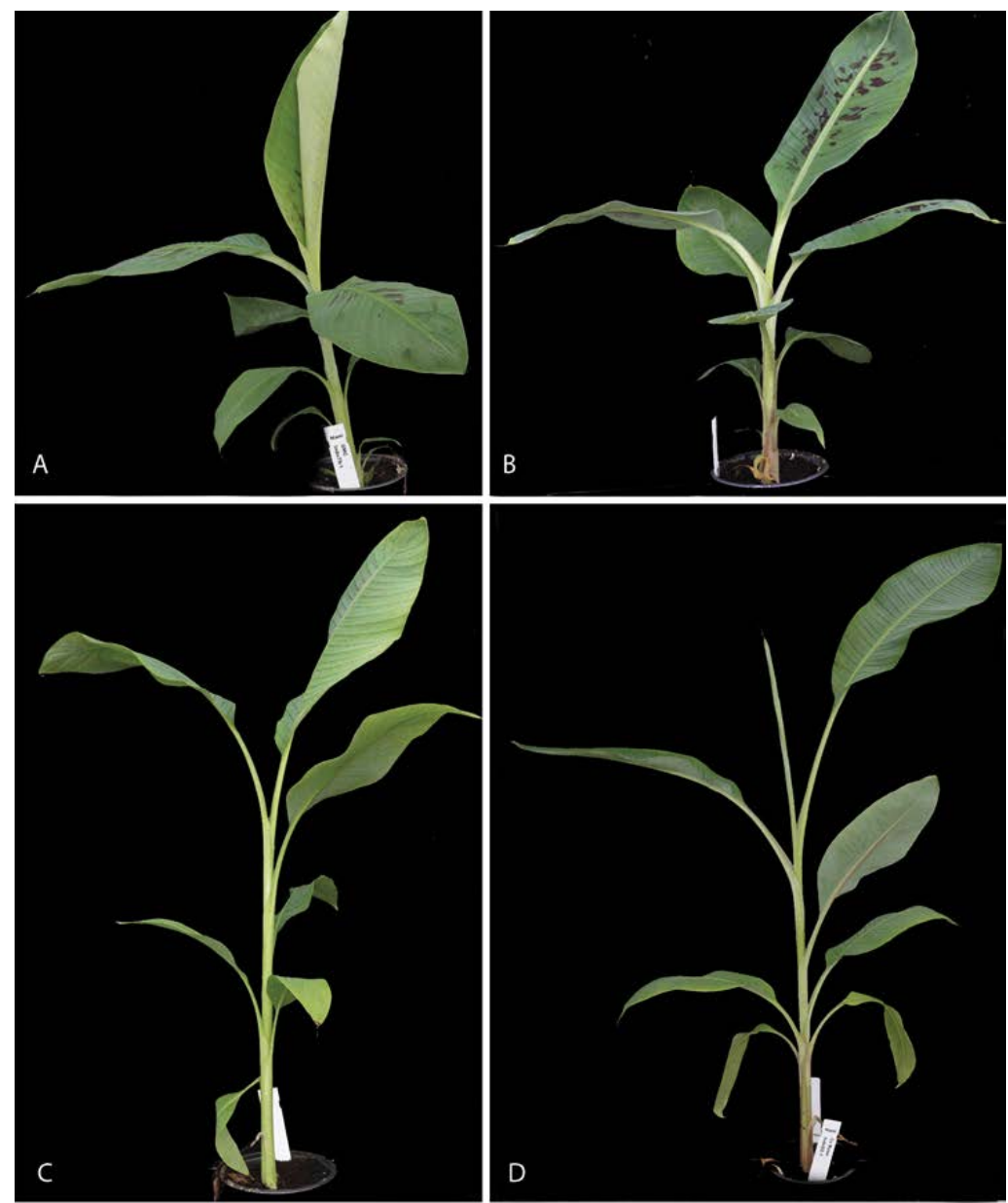

Fig. 1. Four banana varieties used for pathogenicity test. A. Gros Michel, B. Grand Naine, C. Pahang, D. Rejang.

Table 3. Four experimental set-ups of the phenotyping assays.

\begin{tabular}{clccc}
\hline Experiment & \multicolumn{1}{c}{ Host variety } & $\boldsymbol{\Sigma}$ isolates & $\begin{array}{c}\text { Plants } \\
\text { replicate }\end{array}$ & $\boldsymbol{\Sigma}$ experiment \\
\hline 1 & Grand Naine & 63 & 5 & 6 \\
2 & Grand Naine & 25 & 5 & 5 \\
3 & Grand Naine, Gros Michel & 23 & 5 & 1 \\
4 & Grand Naine, Gros Michel, Pahang, Rejang & 15 & 3 & 1 \\
\hline
\end{tabular}




\section{DNA extraction and molecular detection of TR4}

Monosporic cultures of each isolate were grown in Potato Dextrose Broth (PDB) and were incubated under continuous shaking (125 rpm) at room temperature. After seven days incubation, mycelia were collected by filtering the suspension through cheesecloth. Genomic DNA was extracted using the DNA Wizard Magnetic DNA Purification System for Food kit (Promega, USA) and was then quantified using the Invitrogen Quant-iT ${ }^{\mathrm{TM}}$ PicoGreen $^{\mathrm{TM}}$ dsDNA Reagent on a TECAN 2000 analyser (Thermo Fisher Scientific, Switzerland) and finally quality was checked by agarose gel electrophoresis. We used the PCR-TR4 diagnostic primers described by Dita et al. (2010) and a newly loop-mediated isothermal amplification (LAMP) assay as described by Salacinas et al. (2018).
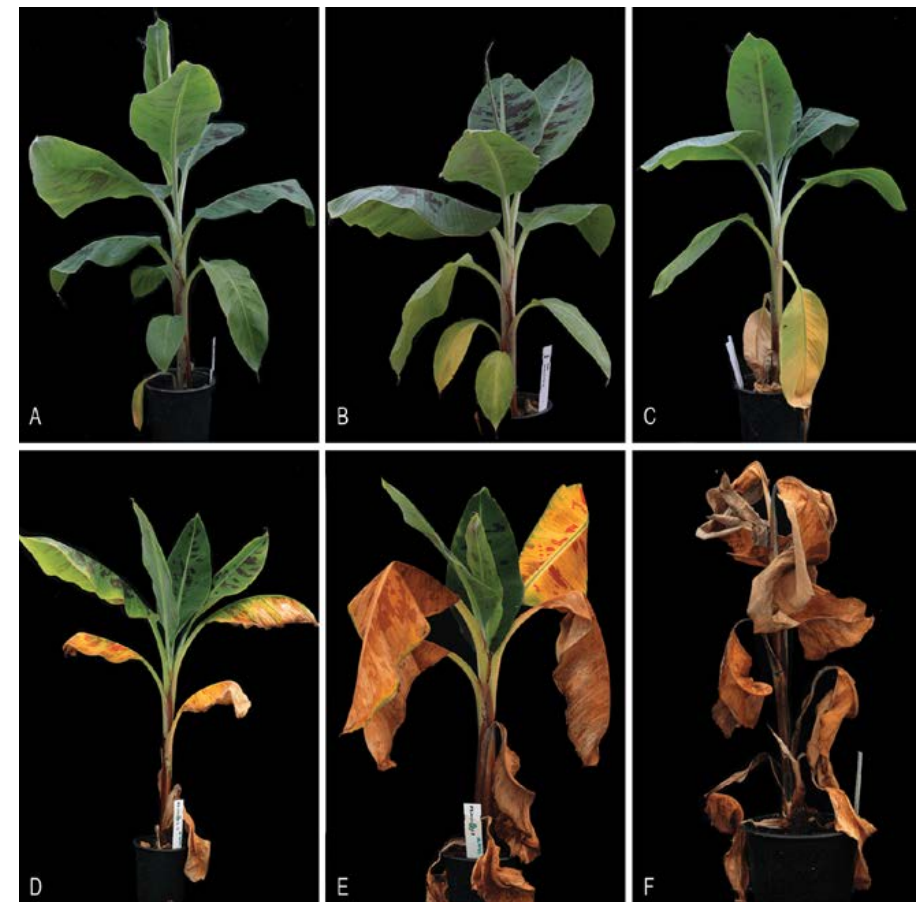

Fig. 2. Phenotyping Fusarium wilt in banana. Foliar diseases severities which were used to assess the pathogenicity of Fusarium spp. eight weeks after inoculation. A. Score 1 (healthy plant), B. Score 2 (initial chlorosis), C. Score 3 (advanced chlorosis $\leq 10 \%$ ), D. Score 4 (extensive chlorosis $10 \%-50 \%$ ), E. Score 5 (extensive chlorosis and necrosis $\leq 50 \%-90 \%$ ), F. Score 6 (extensive necrosis $>90 \%$ or dead plant). 

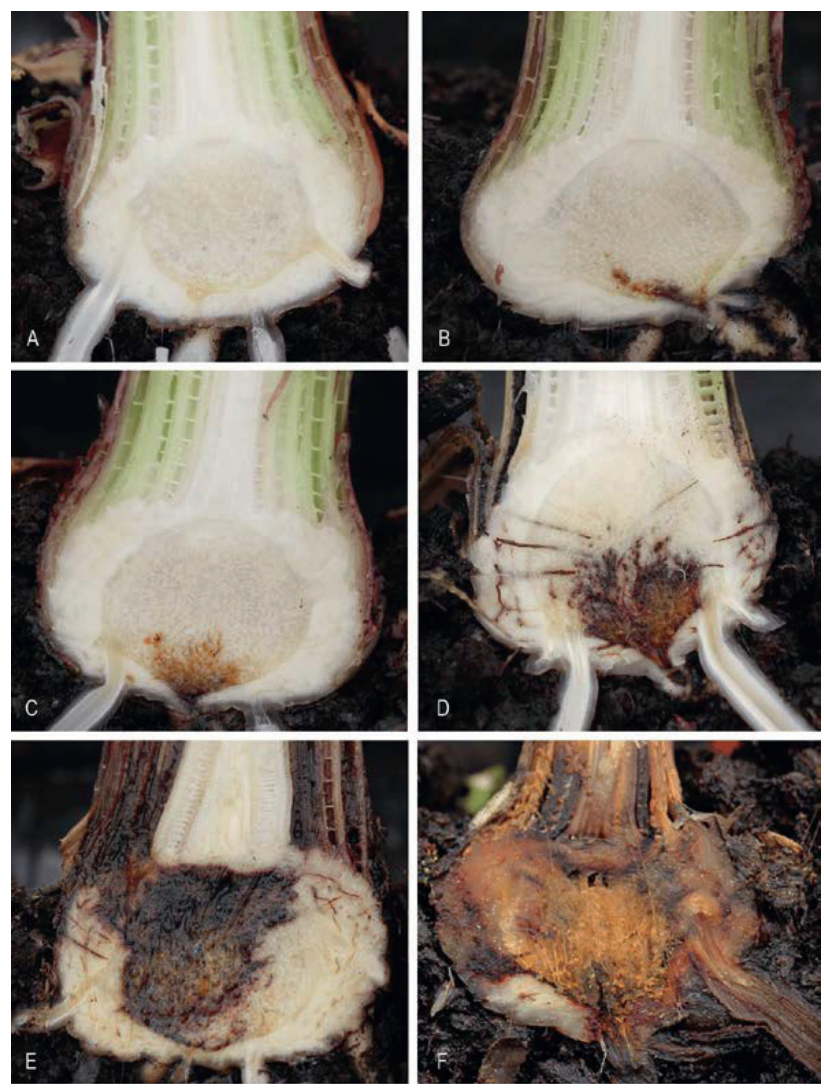

Fig. 3. Phenotyping Fusarium wilt in banana. Internal diseases severities in the corm which were used to assess the pathogenicity of Fusarium spp. eight weeks after inoculation. A. Score 1 (No discoloration), B. Score 2 ( $\leq 5 \%$ discoloration), C. Score 3 (6\% - $10 \%$ discoloration), D. Score $4(21 \%-50 \%$ discoloration), E. Score 5 (50\%-90\% discoloration), F. Score 6 (>90 \% discoloration).

\section{RESULTS}

\section{Symptom development}

The characteristic symptoms of Fusarium wilt on banana, such as leaf chlorosis/ necrosis and internal vascular discoloration were observed on all susceptible plants. Highly pathogenic isolates resulted in plant death within eight weeks after inoculation. The first foliar chlorosis appeared in the third week after inoculation and progressed from the older to the younger leaves, eventually resulting in petiole collapse and desiccation (Fig. 4). The natural anthocyanin blotches on Cavendish and Gros Michel foliage turned yellowish-red on wilting leaves (Fig. 4), but the young furled cigar leaves remained erect and green. Highly pathogenic isolates caused rapid and progressive wilting as well as pseudostem splitting, which eventually resulted in severely stunted plants with constricted pseudostem and curly leaves (Fig. 5).

Vascular symptoms started from the outer part of the corm, went up into the pseudostem and discoloured the first and second strands of the pseudostem leaf sheaths from 
white (see controls) to a myriad of discolorations and patterns. They frequently varied from yellow - reddish-brown and eventually dark brown-black, depending on the severity of infection. Initial colonization by the pathogen was sometimes already observed in the hairy and lateral roots and varied from bright to dark-yellow, from light to dark-brown, or from reddish to brown or almost black (Fig. 6). We also observed discontinued flecking or spotting, discoloured patches, but most frequently a dense discoloration of the bottom of the corm (Fig. 6). These colour and pattern variations were regardless of the isolates or varieties used across this study and severities of foliar symptoms generally correlated well with those in the corm.
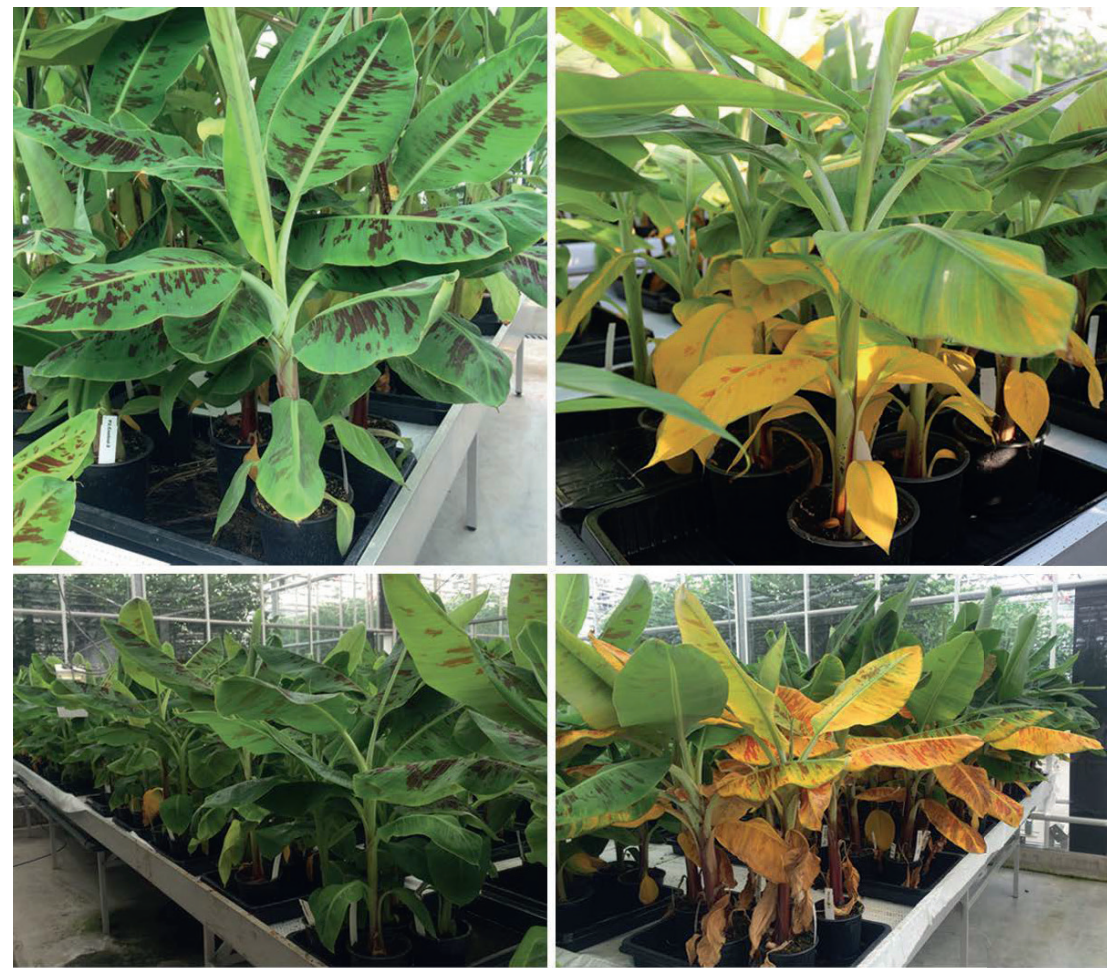

Fig. 4. Phenotyping Fusarium wilt in banana. Overview of symptoms development of Fusarium wilt on banana. Left panels showing plants before inoculation and right panels show plants eight weeks after inoculation. 

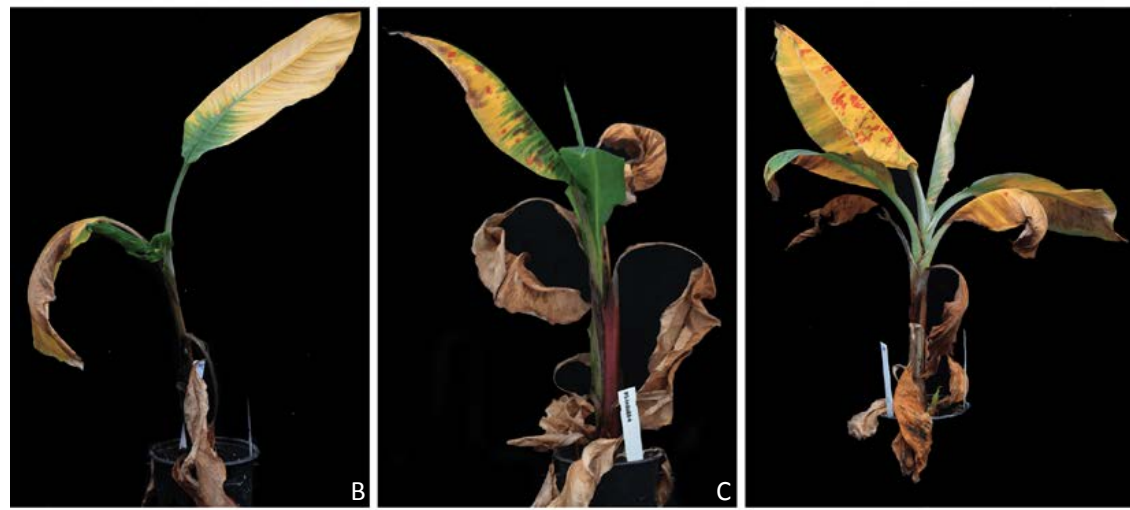

Fig. 5. Phenotyping Fusarium wilt in banana. Secondary external symptoms caused by very aggressive Fusarium odoratissimum isolates. A. Stunting, B. Splitting of pseudostem, C. Wilting

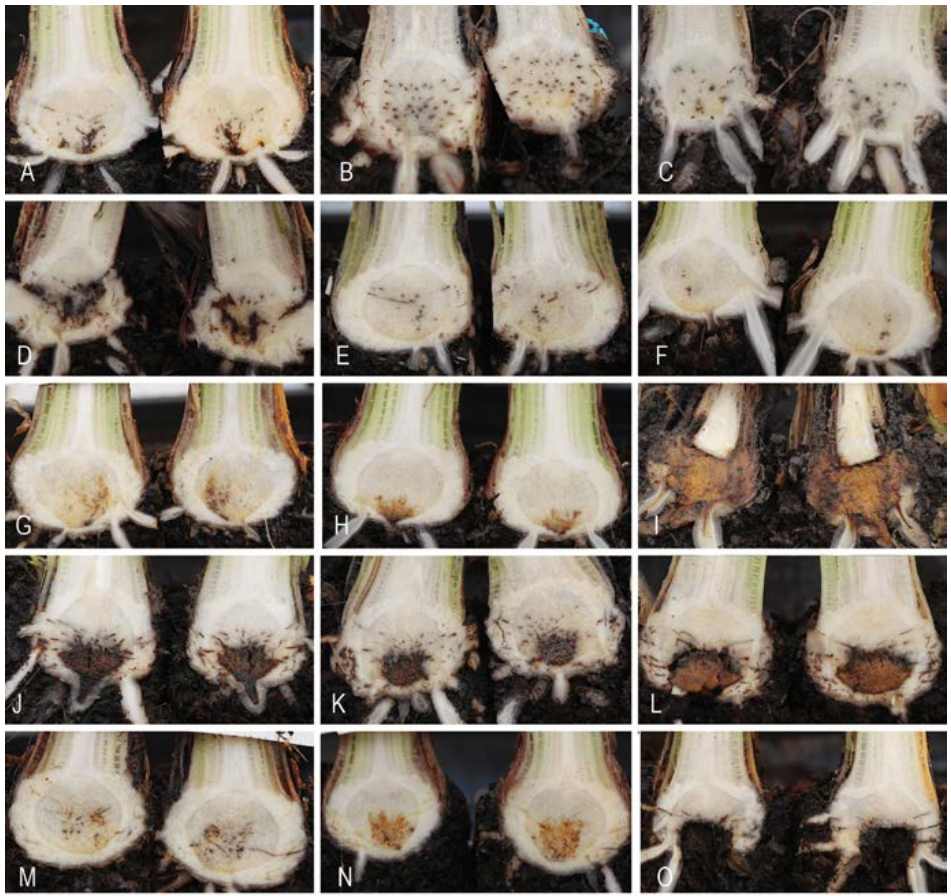

Fig. 6. Phenotyping Fusarium wilt in banana. Overview of corm disease severities at eight weeks after inoculation of Grand Naine with isolates InaCC F836 (A), InaCC F988 (G), InaCC F909 (H), InaCC F988 (M) and InaCC F856 (N) and Gros Michel with isolates InaCC F998 (B), InaCC F997 (C), InaCC F909 (D), InaCC F998 (E), InaCC F936 (F), InaCC F908 (I), InaCC F916 (J), InaCC F998 (K), InaCC F958 (L) and InaCC F978 (O).

\section{Banana - Fusarium interactions}

We performed four rounds of phenotyping to determine the pathogenicity of a significant subsample of the newly described Fusarium species (Maryani et al. 2019) that are associated with Fusarium wilt in banana. The screen with 63 isolates (experiment 1) on Grand Naine showed significant differences in pathogenicity for both the $C$ and $L$ parameters (Table 
4; Supplementing Table 1). An LSD test was used to group the isolates according to their means (Supplementing Fig.1 and Fig.2) and hierarchical cluster analysis resulted in two categories (Fig.7; Supplementing Fig.3). Thirty-four avirulent isolates and 27 virulent isolates (Fig. 7), which essentially matched with the reference TR4 (II5) and Race 1 (CNPMF.R1) strains that are virulent and avirulent on Cavendish banana varieties, respectively. We also observed substantial quantitative variation for aggressiveness among the $F$. odoratissimum TR4 isolates (Fig. 8; Table 4; Supplementing Table 2). An additional statistical analysis of 25 of these isolates showed that the majority of this panel of TR4 isolates is more aggressive than the reference strain II5 (Fig. 8; Table 4; Supplementing Table 2).

Table 4. REML analyses from the fixed model of corm and foliar responses on each experimental set-up.

\begin{tabular}{|c|c|c|c|c|c|c|c|c|c|}
\hline \multirow[b]{2}{*}{ Fixed term } & \multicolumn{4}{|c|}{ Corm (C) } & \multicolumn{4}{|c|}{ Foliar (L) } & \multirow{2}{*}{$\begin{array}{c}\text { Pairwise } \\
\text { correlation } \\
(\mathrm{C}-\mathrm{L})\end{array}$} \\
\hline & ${ }^{1}$ n.d.f. & $\begin{array}{l}\mathbf{F} \\
\text { statistic }\end{array}$ & ${ }^{2}$ d.d.f. & $\begin{array}{l}\text { F } \\
\text { probability }\end{array}$ & n.d.f. & F statistic & d.d.f. & $\begin{array}{l}\text { F } \\
\text { probability }\end{array}$ & \\
\hline \multicolumn{10}{|c|}{$\begin{array}{l}\text { Experiment 1: } \\
\text { GN }\end{array}$} \\
\hline experiments & 6 & 20.95 & 110.9 & $<0.001$ & 6 & 8.62 & 108.3 & $<0.001$ & \\
\hline isolates & 63 & 8.53 & 106.6 & $<0.001$ & 63 & 4.27 & 105.7 & $<0.001$ & 0.73 \\
\hline \multicolumn{10}{|c|}{$\begin{array}{l}\text { Experiment 2: } \\
\text { TR4 on GN }\end{array}$} \\
\hline $\begin{array}{l}\text { biological } \\
\text { replicates }\end{array}$ & 4 & 25.97 & 36.9 & $<0.001$ & 4 & 12.07 & 37.4 & $<0.001$ & \\
\hline isolates & 24 & 1.48 & 37.0 & 0.137 & 24 & 1.93 & 37.5 & 0.034 & 0.68 \\
\hline \multicolumn{10}{|c|}{$\begin{array}{l}\text { Experiment 3: } \\
\text { GN.GM }\end{array}$} \\
\hline varieties & 1 & 144.88 & 185.0 & $<0.001$ & 1 & 62.71 & 184.0 & $<0.001$ & \\
\hline $\begin{array}{l}\text { isolates } \\
\text { varieties. }\end{array}$ & 23 & 13.16 & 185.0 & $<0.001$ & 23 & 8.45 & 184.0 & $<0.001$ & \\
\hline isolates & 23 & 7.25 & 185.0 & $<0.001$ & 23 & 2.21 & 184.0 & $<0.001$ & 0.76 \\
\hline \multicolumn{10}{|c|}{$\begin{array}{l}\text { Experiment 4: } \\
\text { GN.GM. } \\
\text { Rejang. Pahang }\end{array}$} \\
\hline varieties & 3 & 51.57 & 6.6 & $<0.001$ & 3 & 12.27 & 6.6 & 0.004 & \\
\hline $\begin{array}{l}\text { isolates } \\
\text { varieties. }\end{array}$ & 13 & 10.32 & 91.7 & $<0.001$ & 13 & 2.88 & 92.4 & 0.002 & \\
\hline isolates & 33 & 5.78 & 91.7 & $<0.001$ & 33 & 2.36 & 92.4 & $<0.001$ & 0.73 \\
\hline
\end{tabular}




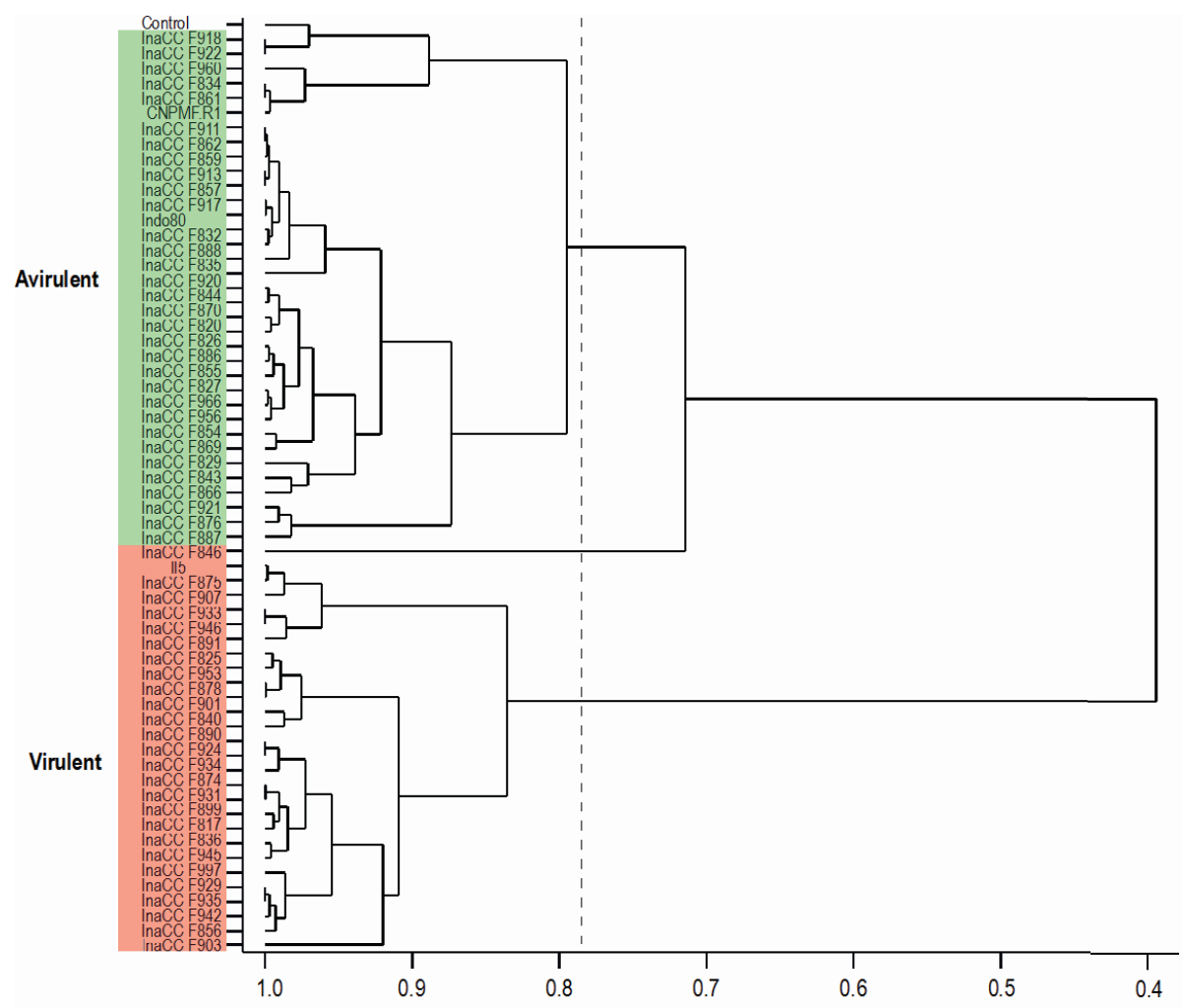

Fig. 7. Hierarchical cluster analysis of 63 Fusarium spp. (experiment 1) that were phenotyped (eight weeks after inoculation) on Grand Naine banana plants using averages of Fusarium wilt disease severities in the corms. Mean values were obtained from the Best Linear Unbiased Predictions (BLUP's, see materials and methods). X-axis values indicate the degree of similarity based on pairwise difference, the vertical dashed line is an arbitrary threshold between significantly different virulence levels of the phenotyped isolates indicated by different colours.

To validate the two observed groups with either virulence or non-virulence for Grand Naine we tested 23 isolates across the collection of new species described by Maryani et al. (2019) on Grand Naine and Gros Michel (experiment 3). This resulted in a highly significant host $x$ pathogen interaction component for the $C$ and $L$ disease parameters (Table 4; Fig. 9), indicating specificity between banana accessions and Fusarium species. In this experiment, we confirmed the abovementioned quantitative variation for aggressiveness on Grand Naine, which was absent on Gros Michel (Supplementing Table 3). In total, 11 isolates were virulent on both banana accessions, whereas 10 isolates were avirulent and virulent on Grand Naine and Gros Michel, respectively. Two isolates, InaCC F984 and InaCC F851, were avirulent on both varieties. Finally, we selected 15 isolates that were virulent on Grand Naine and Gros Michel to investigate whether these strains would cause any disease on wild Pahang and seedless Rejang diploids (experiment 4), but none of the isolates caused any significant 
disease symptoms on these diploids. The fungus was unable to invade the inner parts of the corm, but rather remained outside the cortex without causing any further disease symptoms (Fig. 10; Supplementing Table. 4). Statistical analyses also indicated significant host - pathogen terms for both disease parameters in this experiment (Table 4).
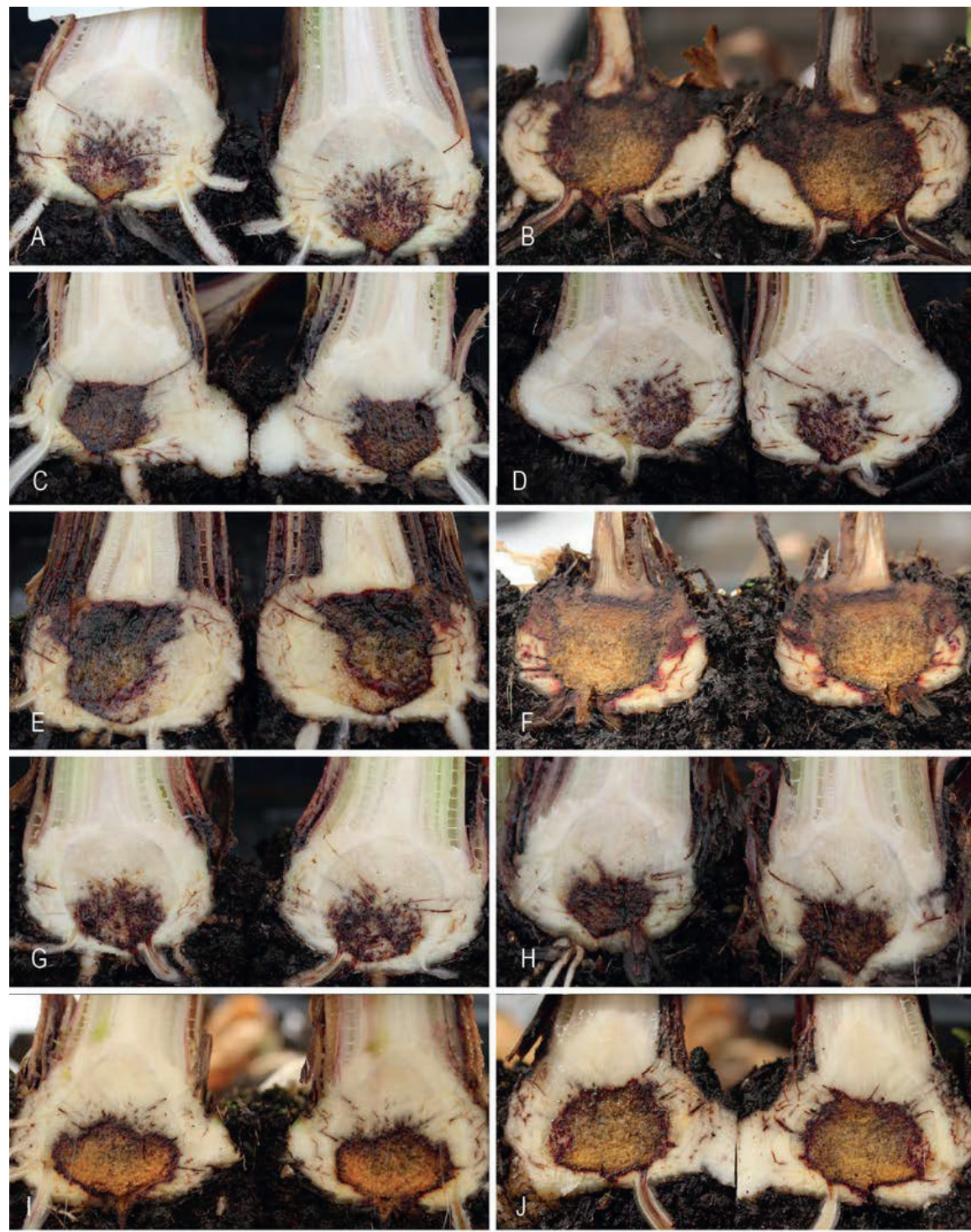

Fig. 8. Phenotyping Fusarium wilt in banana (experiment 2). Overview of corm disease severities at eight weeks after inoculation of Grand Naine with different isolates of Fusarium odoratisimum. A. InaCC F846. B. InaCC F899. C. InaCC F909. D. InaCC F988. E. InaCC 817. F. InaCC F997. G. InaCC F908. H. II5. J. InaCC F874. 

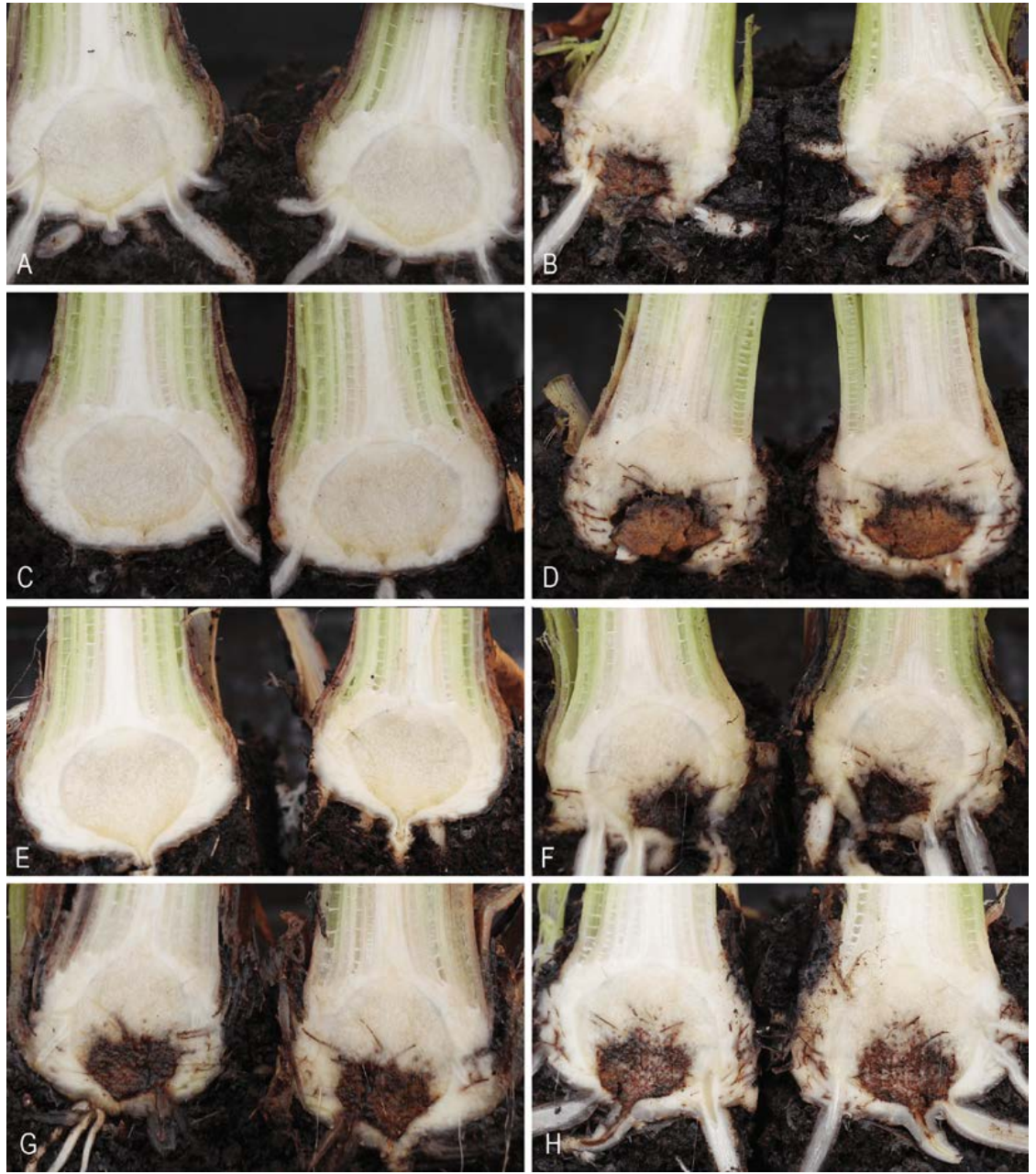

Fig. 9. Phenotyping Fusarium wilt in banana (experiment 3). Overview of corm disease severities at eight weeks after inoculation of Grand Naine (left panel) and Gros Michel (right panel) with various Fusarium spp.. A-B. Fusarium duoseptatum InaCC F916, C-D. F. tardichlamydosporum InaCC F958, E-F. F. grosmichelii InaCC F852, GH. F. odoratissimum II5.

\section{Molecular diagnosis of Fusarium odoratissimum, TR4 isolates}

All isolates that were assayed in the abovementioned phenotyping assays were tested with PCR and LAMP diagnostics. Isolates classified as virulent on Grand Naine were without exception positive for both assays (Table 2). 


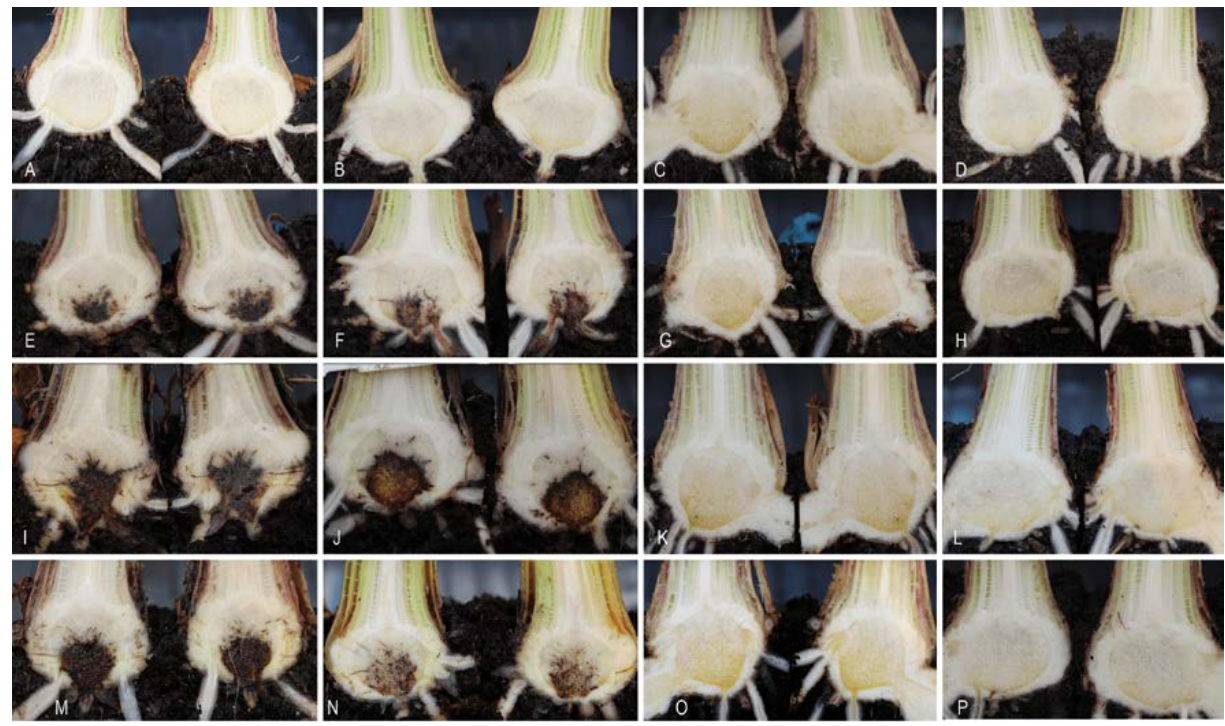

Fig. 10. Phenotyping Fusarium wilt in banana (experiment 4). Overview of corm disease severities at eight weeks after inoculation of Grand Naine (first column), Gros Michel (second column), Pahang (third column) and Rejang (fourth columns) with Fusarium odoratissimum. First row control (A-D), second row reference strain II5 (E-H), third row InaCC F822 (I-L), and fourth row InaCC F856 (M-P).

\section{DISCUSSION}

Host - pathogen interaction data sets are crucial as a foundation for gene discovery (Roelfs \& Martens 1987, Kema 1996, 2000, Figueroa et al. 2013). Early attempts to conceptualize such data were published by Person (1959). Clearly, such data sets are to be complemented by genetic data of both the host and the pathogen whenever possible to identify resistance genes or effectors, respectively. Recent gene discoveries in the Zymoseptoria tritici pathogen of wheat demonstrate the value of isolate collections and complete host - pathogen data sets (Zhang et al. 2017, Kema et al. 2018). Studies in Fusarium wilt have greatly advanced in genomics and genetics such as in tomato and cotton (Ma et al. 2013), but not in banana. Since the epic epidemic in the previous century (Stover 1962), little progress has been made over the past 50 years since TR4 emerged on Cavendish bananas ( $\mathrm{Su}$ et al. 1986). It is therefore not surprising that the focal occurrence has developed in a current pandemic (Ordóñez et al. 2015, Zheng et al. 2018). Moreover, the first resistance gene to TR4 was only identified recently (Dale et al. 2017). Thus, despite the fact that Cavendish saved the industry due to its resistance to Fusarium wilt, the underlying genetics remains elusive.

Some vascular wilt pathogens such as Fusarium oxysporum exclusively colonize xylem vessels which are essential for water and minerals transport in plants. As a result, systemic wilting symptoms and chlorosis are the first exterior symptoms of disease development. However, wilting is a nonspecific symptom that also can be due to other pathogens, or abiotic factors such as drought. The development of diagnostics (Dita et al. 2010, Lievens 2008, Salacinas et al. 2018) is therefore crucial for rapid identification of causal organisms and 
intervention strategies. Here, we combined pathogenicity of Fusarium species belonging to the FOSC on various banana hosts with molecular diagnostics, which confirmed in all cases that the Fusarium strains identified as TR4 unified in one species of $F$. odoratissimum (Maryani et al. 2019). The PCR assay for pathogenic strains on Grand Naine (TR4), has proven to be indispensable for rapid alerts and diagnosis of this particular pathotype in suspicious plants (Dita et al. 2010) as well as the newly developed LAMP assay (Salacinas et al. 2018). Both methods are congruent and unequivocally identified which strains are TR4, as validated by all phenotyping assays. Nevertheless, molecular identification of pathogenic strains should ideally be based on DNA sequences directly related to genes for host-specificity or pathogenicity rather than conserved genes or anonymous molecular marker (Recorbet 2003).

Similar to field evaluations (Stover \& Waite 1960, Sutanto et al. 2013), we used foliage wilting and corm discoloration to assess the pathogenicity of the Indonesian-wide Fusarium panel causing wilt on wild and cultivated banana varieties under greenhouse conditions. However, as pointed out above, corm symptoms are generally more reliable in assessing disease severity (Garcia-Bastidas et al., in prep.), which was also observed in our trials as leaf symptoms were highly variable.

The majority of species in the FOSC is non-pathogenic to any particular host (O'Donnell et al. 2009). Thus, pathogenicity assays can be used to explore genetic diversity as a start to elucidate the underlying genetic basis. Many studies reported genetic diversity in Fusarium wilt pathogens on banana at the molecular level (Groenewald et al. 2006, Fourie et al. 2009, Mostert et al. 2017), but testing pathogenic diversity is still largely void of extended experimental data. All 35 isolates of $F$. odoratissimum pathogenic on Grand Naine, were sampled across the Indonesian archipelago and belong to the physiological group of TR4 strains. None of the other identified species is able to cause disease in Grand Naine. The identification of TR4 in Indonesia was to be expected as the reference strain II5 is of Indonesian origin and was identified in 1992 on Sumatra Island (Budenhagen 2007). It is also believed to be the origin of the first encounter with Cavendish monoculture in Taiwan in 1976 (Hwang \& Ko 2004). Still, the distribution of 35 TR4 isolates of a single species across Indonesia is surprising and seems to be due to demographic factors and the distribution of infected plant materials, similar to recent findings in the Greater Mekong area (Zheng et al. 2018).

Thirteen strains that were not pathogenic on Cavendish, caused disease on Gros Michel, hence represent the genetically diverse Race 1 strains that belong to six different Fusarium species in the FOSC (Maryani et al. 2019). In addition to this broad division of pathogenicity towards Gros Michel and Grand Naine, we observed substantial quantitative variation among the TR4 strains, with many being more aggressive than the II5 reference strain. In general, TR4 isolates are isolated from Cavendish monoculture plantations (Ordóñez et al. 2015), but the Indonesian TR4 isolates in our study were isolated from at least 40 local banana varieties grown in different ecosystem at 34 geographically different locations on six 
Indonesian islands (Maryani et al. 2019). This could contribute to small evolutionary changes, which is reflected by their variable aggressiveness towards Cavendish bananas. It is known that pathogens show extensive genetic diversity in their centres of origin (Islam et al. 2016, Kema et al. 1996, Stukenbrock \& McDonald 2008). We observed a similar situation for Fusarium species with pathogenicity to banana in Indonesia (Maryani et al. 2019), which revealed eleven phylogenetically diverse species as well as genomic variation within the species by genotyping-by-sequencing across these Fusarium species (Maryani et al. 2018). We do not know how such diversity is generated, but presume it results from extended coevolution between the wide range of genetic diversity in banana germplasm in Indonesia (Perrier et al. 2011, Nasution 1990). Until now, sexual reproduction in this pathogen has not been discovered and population analyses (Fourie et al. 2006) do not hint towards such a niche. Taylor et al. (1999) demonstrate that the phylogenetic species concept of asexual and clonal fungi does not preclude recombination and used Fusarium causing Panama disease as an example that asexual and sexual reproductive biology not necessarily align with clonal or recombining populations, respectively. This is in accord with Buxton (1962), who demonstrated parasexuality in Fusarium oxysporum strains causing wilting in Gros Michel, which evidently could result in any form of diversification that might manifest itself through subtle morphological changes, including pathogenicity. Other $F$. oxysporum ff.spp. such as $f$. sp. niveum on watermelon (Larkin et al. 1990) and f. sp. ciceris on chickpea (Jiménez-Gasco et al. 2004) showed also a wide range of aggressiveness which was attributable to particular races.

Gene-for-gene interactions have been described for various ff.spp. of $F$. oxysporum (Michelse \& Rep 2009). However, the race concept in Fusarium wilt pathogens on banana is crude and merely depends on pathogenicity of a limited number of strains on a few banana accessions, usually evaluated under field conditions. Stover and Waite (1960) in their first experiments used three isolates and found Race 1 and Race 2 to be highly pathogenic on Gros Michel and Bluggoe, respectively. The latter accession and Cavendish were highly resistant to Race 1, but Race 4 affects Cavendish bananas (Su et al. 1986). In these experiments, susceptible varieties succumbed to pathogenic isolates, while resistant accessions did not develop any symptom. However, expanding the number of Fusarium species and banana accessions will almost certainly extend and complicate this rudimentary system. Here, we tested 23 isolates across seven Fusarium species that are pathogenic on Grand Naine and Gros Michel and found a strong interaction between isolates and banana genotypes, indicative for GFG, which is in accord with previous reports (Stover \& Waite 1960, Su et al. 1986) as well as the most recent reports of Garcia-Bastidas et al. (in prep.), who phenotyped 242 banana accessions with TR4 strain II5 and Race 1 strain CNPMF.R1. In our study, six Fusarium spp. are pathogenic on Gros Michel, clearly demonstrating that pathogenicity is not species specific unlike the pathogenicity toward Grand Naine. We also validated the resistance to the diverse 
Indonesian TR4 isolates as well as other Fusarium species in M. acuminata var. malaccensis, a highly dispersed species originating from Sumatra and the Malaysian peninsula (Simmonds \& Shepherd 1995). The genome of this species was sequenced and it is the source of the first identified and cloned resistance gene to TR4 (D'Hont et al. 2012, Dale et al. 2017). In our surveys across Indonesia we never observed any external Fusarium wilt symptoms in the forests of Java and Sumatra (Maryani et al. 2019, Ahmad \& Maryani 2014, personal observation). Likewise, Rejang was found to be resistant to this wide Fusarium diversity in our greenhouse assays, which confirmed our observations from banana backyard home plantations in Java and Sumatra (Poerba \& Pangesti 2017, pers. comm.). Also, recent reports on the screening of local Indonesian banana varieties against Fusarium wilt showed that both diploid and tetraploid Pisang Rejang genotypes were highly resistant to TR4 (Handayani et al. 2017). Hence, the deciphering of the genetic basis of resistance to Fusarium wilt in cultivated and wild bananas is relevant, possible and urgent. Our study provides the well genotyped and phenotyped pathogen isolates that should be used for such analyses.

\section{ACKNOWLEDGEMENTS}

This research was supported by KNAW-SPIN Project "The Indonesian banana: Protecting a staple food from Panama disease collapse and exploiting its genetic diversity for discovery research". NM was also supported by a DIKTI (Directorate General of Higher Education) Scholarship, Ministry of Research, Technology and Higher Education, Indonesia. Banana research at Wageningen University and Research (WUR) is supported by the Dutch Dioraphte Foundation endowed chair in Tropical Phytopathology of GHJK at the WUR-Laboratory of Phytopathology. We thank Odette Mendes (Biointeractions and Plant Health, Wageningen Plant Research, Wageningen University, The Netherlands) for helping us in the LAMP experiment. We also thank the International Musa Germplasm International Transit Center, Biodiversity International, Leuven, Belgium, for providing Pahang and Rejang plantlets. Corbana, Costa Rica, provided Gros Michel plantlets and Rahan Meristem, Israel, supports the WUR banana program by providing Grand Naine plantlets.

\section{REFERENCES}

Buddenhagen I (2007). Understanding strain diversity in Fusarium oxysporum f. sp. cubense and history of introduction of'Tropical Race 4'to better manage banana production. Paper presented at the International Symposium on Recent Advances in Banana Crop Protection for Sustainable Production and Improved Livelihoods. Page:828.

Buxton EW (1962). Parasexual recombination in the banana-wilt Fusarium. Transactions of the British Mycological Society 45(2):274-279.

Czislowski E, Fraser-Smith S, Zander M, et al. (2018). Investigation of the diversity of effector genes in the banana pathogen, Fusarium oxysporum f. sp. cubense, reveals evidence of horizontal gene transfer. Molecular plant pathology 19(5): 1155-1171.

Dale J, James A, Paul JY, et al. 2017. Transgenic Cavendish bananas with resistance to Fusarium wilt tropical race 4. Nature communications 8(1): 1496.

Dita M, Waalwijk C, Buddenhagen I, Souza Jr M, Kema GHJ (2010). A molecular diagnostic for tropical race 4 of the banana fusarium wilt pathogen. Plant Pathology, 59(2), 348-357.

D'Hont A, Denoeud F, Aury JM, et al. (2012). The banana (Musa acuminata) genome and the evolution of monocotyledonous plants. Nature 488(7410):213-217. 
Figueroa M, Alsderman S, Garvin DF, et al. (2013). Infection of Brachypodium distachyon by Formae Speciales of Puccinia graminis: Early Infection Events and Host-Pathogen Incompatibility. PLoS ONE 8(2): e56857. doi:10.1371/journal.pone.0056857.

Fisher MC, Hawkins NJ, Sanglard D, et al. (2018). Worldwide emergence of resistance to antifungal drugs challenges human health and food security. Science 360(6390):739.

Fourie G, Steenkamp ET, Gordon TR, et al. (2009). Evolutionary relationships among the Fusarium oxysporum $\mathrm{f}$. sp. cubense vegetative compatibility groups. Applied Environmental Microbiology 75(14):4770-4781.

Friesen TL, Faris JD, Solomon PS, et al. (2008). Host-specific toxins: effectors of necrotrophic pathogenicity. Cellular Microbiology 10(7):1421-1428.

Gerlach KS, Bentley S, Moore NY, et al. (2000). Characterization of Australian isolates of Fusarium oxysporum $\mathrm{f}$. sp. cubense by DNA fingerprinting analysis. Australian Journal of Agricultural Research 51:945-953.

Guo L, Yang L, Liang C, et al. (2015). Differential Colonization Patterns of Bananas (Musa spp.) by Physiological Race 1 and Race 4 Isolates of Fusarium oxysporum f. sp. cubense. Journal of Phytopathology 163(10): 807817.

Gurr S, Samalova M, Fisher M (2011). The rise and rise of emerging infectious fungi challenges food security and ecosystem health. Fungal Biology Reviews 25: 181-188.

Handayani T, Martanti D, Poerba YS, et al. (2017). Deteksi awal ketahanan beberapa aksesi pisang lokal dan hasil persilangan terhadap penyakit layu Fusarium (Foc VCG 01213/16 TR4). Journal Hortikultura Indonesia 8(2):88-96.

Hermanto C, Sutanto A, Edison H, et al. (2009). Incidence and distribution of Fusarium wilt disease of banana in Indonesia. Paper presented at the International ISHS-ProMusa Symposium on Global Perspectives on Asian Challenges. Page: 897.

Islam MT, Croll D, Gladieux P, et al. (2016). Emergence of wheat blast in Bangladesh was caused by a South American lineage of Magnaporthe oryzae. BMC Biology 14(1):84

Jiménez-Gasco MM, Milgroom MG, Jiménez-Díaz RM (2004). Stepwise evolution of races in Fusarium oxysporum f. sp. ciceris inferred from fingerprinting with repetitive DNA sequences. Phytopathology 94 (3): 228-235.

Kema GHJ, Sayoud R, Annone J, et al. (1996). Genetic variation for virulence and resistance in the wheatMycosphaerella graminicola pathosystem. II: analysis of interactions between pathogen isolates and host cultivars. Phytopathology 86(2):213-220.

Kema GHJ, Verstappen ECP, Waalwijk C (2000). Avirulence in the wheat Septoria tritici leaf blotch fungus Mycosphaerella graminicola is controlled by a single Locus. Molecular Plant-Microbe Interaction 13(12):1375-1379.

Kema GHJ, Weise S (2013). Pathogens: Appeal for funds to fight banana blight. Nature 504(7479): 218-218.

Kema GHJ, Mirzadi GA, Aouini L, et al. (2018). Stress and sexual reproduction affect the dynamics of the wheat pathogen effector AvrStb6 and strobilurin resistance. Nature Genetics. 10.1038/s41588-018-0052-9

Larkin RP, Hopkins DL, Martin FN (1990). Vegetative compatibility within Fusarium oxysporum f. sp. niveum and its relationship to virulence, aggressiveness, and race. Canadian Journal of Microbiology 36(5):352-358.

Lievens B, Rep M, Thomma B (2008). Recent developments in the molecular discrimination of formae speciales of Fusarium oxysporum. Pest Management Science 64(8): 781-788.

Ma LJ, Geiser DM, Proctor RH, et al. (2013). Fusarium pathogenomics. Annual review of microbiology 67(1): 399416.

Maryani N, Lombard L, Poerba YS, et al. (2019). Phylogeny and genetic diversity of the banana Fusarium wilt pathogen Fusarium oxysporum f. sp. cubense in the Indonesian centre of origin. Studies in Mycology $\mathbf{9 2}$ 155-194.

Maryani N, Seidl MF, Crous PW, et al. (2018). Genotyping-by-sequencing reveals extensive genotypic diversity of Fusarium oxysporum f. sp. cubense from Indonesia. Submitted.

Moore N, Hargreaves P, Pegg K, et al. (1991). Characterisation of strains of Fusarium oxysporum f. sp. cubense by production of volatiles. Australian Journal of Botany 39(2):161-166.

Mostert D, Molina A, Daniells J, et al. (2017). The distribution and host range of the banana Fusarium wilt fungus, Fusarium oxysporum f. sp. cubense, in Asia. PloS ONE 12(7): e0181630.

Nasution RE (1990). A Taxonomic Study of the Species Musa Acuminata Colla with its Intraspesific Taxa in Indonesia. Ph.D dissertation. Tokyo University of Agriculture, Japan.

O'Donnell K, Kistler HC, Cigelnik E, et al. (1998). Multiple evolutionary origins of the fungus causing Panama disease of banana: Concordant evidence from nuclear and mitochondrial gene genealogies. PNAS 95(5):2044-2049.

Ordóñez N, Seidl MF, Waalwijk C, et al. (2015). Worse comes to worst: bananas and Panama disease-when plant and pathogen clones meet. PLoS Pathogens 11(11): e1005197. 
Perrier X, De Langhe E, Donohue M, et al. (2011). Multidisciplinary perspectives on banana (Musa spp.) domestication. PNAS 108(28): 11311-11318.

Person C (1959). Gene-For-Gene relationships in host: parasite systems. Canadian journal of botany 37(5):11011130.

Ploetz RC (1994). Panama disease: return of the first banana menace. International journal of pest management 40(4):326-336.

Ploetz RC, Pegg K. (1997). Fusarium wilt of banana and Wallace's line: Was the disease originally restricted to his Indo-Malayan region? Australian plant pathology 26(4): 239-249.

Ploetz RC (2005). Panama disease, an old nemesis rears its ugly head: part 1, the beginnings of the banana export trades. Plant Health Progress (December). Pages:1-10.

Ploetz RC (2015). Fusarium Wilt of Banana. Phytopathology 105(12):1512-1521.

Recorbet GS, Christian O, Edel C, et al. (2003). Wanted: pathogenesis-related marker molecules for Fusarium oxysporum. New Phytologist 159(1):73-92.

Roelfs AP, Martens JW (1987). An international system of nomenclature for Puccinia graminis f. sp. tritici. Phytopathology 78:526-533.

Salacinas M, Ordóñez N, Mendes O, et al. (2018). A loop-mediated isothermal amplification assay based on unique markers derived from genotyping-by-sequencing data for rapid in-plant diagnosis of Fusarium oxysporum f. sp. cubense tropical race 4 in banana. Submitted

Simmonds N, Shepherd K (1955). The taxonomy and origins of the cultivated bananas. Journal of the Linnean Society of London, Botany 55: 302-312.

Simmonds N (1962). The Evolution of Bananas. London: Longman Itd.

Snyder WC, Hansen HN (1940). The Species Concept in Fusarium. American Journal of Botany 27(2): 64-67.

Stover R, Waite B (1960). Studies on Fusarium wilt of bananas: V. Pathogenicity and distribution of Fusarium oxysporum f. sp. cubense Races 1 and 2. Canadian journal of botany 38(1): 51-61.

Stover R (1962). Fusarial wilt (Panama Disease) of bananas and other Musa species. Oxford, UK: Oxford university press.

Stukenbrock EH, McDonald BA (2008). The origins of plant pathogens in agro-ecosystems. Annual review of phytopathology 46:75-100.

Su HJ, Hwang, S, Ko W (1986). Fusarial wilt of Cavendish bananas in Taiwan. Plant Disease 70(9):814-818.

Sutanto A, Sudarsono, Sukma D, et al. (2013). The study and early evaluation of resistance of banana accessions for wilt disease caused by Fusarium oxyporum f. sp. cubense VCG 01213/16 (TR4). Bogor: Research Center for Bioresources and Biotechnology, Bogor Agricultural University. Pages:291-295.

Takken F, Rep M (2010). The arms race between tomato and Fusarium oxysporum. Molecular Plant Pathology 11(2):309-314.

Taylor JW, Jacobson DJ, Fisher MC (1999). The evolution of asexual fungi: reproduction, speciation and classification. Annual review of phytopathology 37(1):197-246.

VSN International (2015). Genstat for Windows 18th Edition. VSN International, Hemel Hempstead, UK. Web page: Genstat.co.uk.

Zheng SJ, García-Bastidas FA, Li X, et al. (2018). New geographical insights of the latest expansion of Fusarium oxysporum f. sp. cubense Tropical Race 4 into the Greater Mekong Subregion. Frontiers in Plant Science 9: 457. doi: 10.3389/fpls.2018.00457. 


\section{Supplementary data}

Supplementing table 1. Disease severities in the corm and foliar symptoms of experiment 1 . Mean values were obtained from the random model (see materials and methods).

\begin{tabular}{|c|c|c|c|c|c|}
\hline \multirow{2}{*}{ Species } & \multirow{2}{*}{$\begin{array}{l}\text { Accession } \\
\text { number }\end{array}$} & \multicolumn{2}{|c|}{ Mean } & \multirow{2}{*}{$\sum$ Experiment } & \multirow{2}{*}{ ¿Plant } \\
\hline & & C & $\mathbf{L}$ & & \\
\hline \multirow[t]{6}{*}{ Fusarium duoseptatum } & InaCC F829 & 1.92 & 2.72 & 1 & 3 \\
\hline & InaCC F920 & 2.11 & 2.25 & 3 & 15 \\
\hline & Indo80 & 2.41 & 2.72 & 1 & 3 \\
\hline & InaCC F835 & 2.45 & 2.21 & 3 & 15 \\
\hline & InaCC F921 & 2.69 & 2.50 & 1 & 5 \\
\hline & InaCC F911 & 2.38 & 3.30 & 1 & 2 \\
\hline \multirow[t]{9}{*}{ F. grosmichelii } & InaCC F861 & 1.80 & 2.19 & 3 & 15 \\
\hline & InaCC F820 & 2.13 & 2.24 & 4 & 20 \\
\hline & InaCC F855 & 2.17 & 2.51 & 2 & 7 \\
\hline & InaCC F854 & 2.30 & 2.30 & 3 & 15 \\
\hline & InaCC F862 & 2.38 & 2.77 & 1 & 2 \\
\hline & InaCC F859 & 2.38 & 2.18 & 2 & 10 \\
\hline & InaCC F888 & 2.42 & 2.47 & 3 & 15 \\
\hline & InaCC F832 & 2.43 & 2.40 & 3 & 15 \\
\hline & InaCC F887 & 2.65 & 2.72 & 1 & 3 \\
\hline F. hexaseptatum & InaCC F866 & 2.05 & 2.24 & 4 & 17 \\
\hline \multirow[t]{3}{*}{ F. kalimantanense } & InaCC F918 & 1.43 & 2.72 & 1 & 3 \\
\hline & InaCC F922 & 1.43 & 2.74 & 1 & 3 \\
\hline & InaCC F917 & 2.41 & 2.55 & 5 & 25 \\
\hline F. oxysporum & CNPMF.R1 & 1.79 & 1.63 & 4 & 20 \\
\hline \multirow[t]{6}{*}{ F. phialophorum } & InaCC F834 & 1.80 & 2.65 & 3 & 15 \\
\hline & InaCC F843 & 1.99 & 2.36 & 3 & 15 \\
\hline & InaCC F844 & 2.10 & 2.43 & 4 & 20 \\
\hline & InaCC F826 & 2.19 & 2.17 & 4 & 20 \\
\hline & InaCC F827 & 2.22 & 2.33 & 2 & 10 \\
\hline & InaCC F869 & 2.27 & 3.42 & 2 & 7 \\
\hline \multirow[t]{3}{*}{ F. purpurascens } & InaCC F886 & 2.18 & 2.38 & 4 & 20 \\
\hline & InaCC F966 & 2.22 & 2.31 & 3 & 15 \\
\hline & InaCC F913 & 2.39 & 2.50 & 1 & 5 \\
\hline F. sangayamense & InaCC F960 & 1.70 & 2.01 & 4 & 20 \\
\hline F. tardichlamydosporum & InaCC F956 & 2.23 & 2.02 & 3 & 15 \\
\hline \multirow[t]{11}{*}{ F. odoratissimum } & InaCC F870 & 2.15 & 2.03 & 1 & 5 \\
\hline & InaCC F857 & 2.39 & 3.34 & 1 & 5 \\
\hline & InaCC F876 & 2.73 & 2.77 & 1 & 3 \\
\hline & InaCC F846 & 3.14 & 2.91 & 1 & 5 \\
\hline & InaCC F891 & 3.72 & 3.05 & 3 & 15 \\
\hline & InaCC F933 & 3.77 & 3.87 & 3 & 15 \\
\hline & InaCC F946 & 3.77 & 3.23 & 2 & 10 \\
\hline & InaCC F875 & 3.86 & 3.68 & 3 & 15 \\
\hline & II5 & 3.87 & 3.83 & 7 & 35 \\
\hline & InaCC F907 & 3.91 & 3.49 & 3 & 15 \\
\hline & InaCC F890 & 4.08 & 3.64 & 2 & 10 \\
\hline
\end{tabular}


Pathogenic diversity of Indonesian Fusarium wilt pathogens

\begin{tabular}{rlrrr}
\hline InaCC F840 & 4.12 & 3.11 & 1 & 5 \\
InaCC F825 & 4.16 & 3.48 & 1 & 5 \\
InaCC F953 & 4.17 & 3.96 & 3 & 15 \\
InaCC F878 & 4.20 & 4.07 & 3 & 15 \\
InaCC F901 & 4.20 & 3.67 & 3 & 15 \\
InaCC F874 & 4.31 & 3.63 & 3 & 15 \\
InaCC F924 & 4.34 & 3.73 & 3 & 15 \\
InaCC F934 & 4.34 & 3.59 & 3 & 15 \\
InaCC F931 & 4.39 & 3.93 & 2 & 10 \\
InaCC F899 & 4.39 & 4.30 & 3 & 15 \\
InaCC F817 & 4.41 & 3.66 & 2 & 10 \\
InaCC F836 & 4.43 & 3.59 & 1 & 5 \\
InaCC F997 & 4.45 & 4.04 & 3 & 15 \\
InaCC F945 & 4.46 & 3.79 & 3 & 15 \\
InaCC F935 & 4.52 & 3.68 & 3 & 15 \\
InaCC F942 & 4.52 & 3.62 & 3 & 15 \\
InaCC F822 & 4.53 & 4.08 & 5 & 25 \\
InaCC F856 & 4.55 & 3.57 & 4 & 20 \\
InaCC F929 & 4.58 & 3.87 & 3 & 15 \\
InaCC F903 & 4.71 & 4.19 & 3 & 15 \\
\hline
\end{tabular}

Supplementing table 2. Disease severities in the corm and foliar symptoms of experiment 2. Mean values were obtained from the fixed model (see materials and methods).

\begin{tabular}{llllr}
\hline \multirow{2}{*}{ Accession number } & \multicolumn{2}{c}{ Mean } & $\boldsymbol{\Sigma}$ Experiment & $\boldsymbol{\Sigma}$ P Plant \\
\cline { 2 - 4 } InaCC F933 & 3.3 & 4.1 & 2 & 10 \\
InaCC F870 & 3.4 & 3.3 & 1 & 5 \\
InaCC F891 & 3.4 & 3.1 & 2 & 10 \\
InaCC F907 & 3.8 & 3.8 & 1 & 5 \\
InaCC F946 & 3.8 & 3.7 & 1 & 5 \\
InaCC F878 & 3.8 & 4.3 & 2 & 10 \\
InaCC F953 & 3.8 & 4.1 & 2 & 10 \\
InaCC 924 & 4.1 & 3.8 & 2 & 10 \\
InaCC F934 & 4.2 & 3.7 & 2 & 10 \\
InaCC F942 & 4.3 & 3.7 & 2 & 10 \\
InaCC F945 & 4.3 & 3.9 & 2 & 10 \\
InaCC F817 & 4.4 & 4.7 & 1 & 5 \\
II5 & 4.5 & 4.0 & 5 & 25 \\
InaCC F935 & 4.5 & 3.8 & 3 & 15 \\
InaCC F875 & 4.5 & 4.3 & 2 & 10 \\
InaCC F856 & 4.6 & 4.0 & 2 & 10 \\
InaCC F890 & 4.6 & 4.2 & 2 & 10 \\
InaCC F929 & 4.7 & 4.2 & 2 & 10 \\
InaCC F822 & 4.7 & 4.3 & 3 & 15 \\
InaCC F901 & 4.7 & 4.2 & 3 & 15 \\
InaCC F931 & 4.8 & 4.5 & 1 & 5 \\
InaCC F997 & 4.8 & 4.4 & 2 & 10 \\
InaCC F874 & 4.9 & 3.5 & 2 & 10 \\
InaCC F899 & 4.9 & 4.9 & 3 & 15 \\
\hline & & & &
\end{tabular}




\begin{tabular}{lllll}
\hline InaCC F903 & 5.3 & 4.8 & 3 & 15 \\
\hline
\end{tabular}

Supplementing table 3. Disease severities in the corm and foliar symptoms of experiment 3. Mean values were obtained from the fixed model (see materials and methods).

\begin{tabular}{|c|c|c|c|c|c|c|}
\hline \multirow{3}{*}{ Species } & \multirow{3}{*}{$\begin{array}{l}\text { Accession } \\
\text { number }\end{array}$} & \multicolumn{4}{|c|}{ Mean } & \multirow{3}{*}{ Pathogenicity } \\
\hline & & \multicolumn{2}{|c|}{ Grand Naine } & \multicolumn{2}{|c|}{ Gros Michel } & \\
\hline & & C & $\mathbf{L}$ & c & L & \\
\hline Fusarium cugenangense & InaCC F984 & 1.4 & 1.2 & 1.4 & 1.2 & NA \\
\hline \multirow[t]{3}{*}{ F. duoseptatum } & InaCC F971 & 1.4 & 1.2 & 4.2 & 2.4 & Race 1 \\
\hline & InaCC F979 & 1.4 & 1.2 & 5.0 & 4.4 & Race 1 \\
\hline & InaCC F916 & 2.2 & 1.0 & 4.8 & 4.4 & Race 1 \\
\hline \multirow[t]{4}{*}{ F. grosmichelii } & InaCC F848 & 1.6 & 1.4 & 4.2 & 2.8 & Race 1 \\
\hline & InaCC F851 & 1.6 & 1.4 & 2.6 & 1.6 & NA \\
\hline & InaCC F853 & 1.6 & 1.6 & 4.6 & 3.6 & Race 1 \\
\hline & InaCC F833 & 2.0 & 1.8 & 4.6 & 4.2 & Race 1 \\
\hline F. oxysporum & CNPMF.R1 & 1.2 & 1.0 & 4.4 & 2.8 & Race 1 \\
\hline F. phialophorum & InaCC F996 & 2.4 & 2.2 & 4.0 & 2.6 & Race 1 \\
\hline F. tardichlamydosporum & InaCC F958 & 1.0 & 1.6 & 4.4 & 3.8 & Race 1 \\
\hline \multirow[t]{11}{*}{ F. odoratissimum } & InaCC F927 & 3.2 & 2.6 & 4.4 & 3.8 & TR4 \\
\hline & InaCC F936 & 3.6 & 2.2 & 4.2 & 3.8 & TR4 \\
\hline & InaCC F908 & 4.0 & 3.2 & 5.2 & 5.0 & TR4 \\
\hline & 115 & 4.2 & 2.6 & 4.2 & 2.5 & TR4 \\
\hline & InaCC F909 & 4.2 & 4.2 & 5.6 & 5.4 & TR4 \\
\hline & InaCC F817 & 4.3 & 3.7 & 3.8 & 4.3 & TR4 \\
\hline & InaCC F988 & 4.4 & 3.6 & 4.6 & 4.0 & TR4 \\
\hline & InaCC F836 & 4.4 & 3.6 & 4.2 & 3.6 & TR4 \\
\hline & InaCC F846 & 4.6 & 4.3 & 4.8 & 5.2 & TR4 \\
\hline & InaCC F998 & 4.8 & 4.0 & 4.2 & 4.2 & TR4 \\
\hline & InaCC F997 & 5.3 & 4.8 & 4.0 & 4.0 & TR4 \\
\hline
\end{tabular}

Supplementing table 4. Disease severities in the corm and foliar symptoms of experiment 4. Mean values were obtained from the fixed model (see materials and methods).

\begin{tabular}{|c|c|c|c|c|c|c|c|c|c|}
\hline \multirow{3}{*}{ Species } & \multirow{3}{*}{$\begin{array}{l}\text { Accession } \\
\text { number }\end{array}$} & \multicolumn{6}{|c|}{ Mean } & & \\
\hline & & \multicolumn{2}{|c|}{ Pahang } & \multicolumn{2}{|c|}{ Rejang } & \multicolumn{2}{|c|}{ Grand Naine } & \multicolumn{2}{|c|}{ Gros Michel } \\
\hline & & C & $\mathbf{L}$ & C & $\mathbf{L}$ & C & L & C & $\mathbf{L}$ \\
\hline Fusarium sangayamense & InaCC F960 & 1.0 & 1.7 & NA & NA & 1.0 & 1.3 & 1.3 & 2.3 \\
\hline F. kalimantanense & InaCC F917 & 1.0 & 1.7 & 1.0 & 2.0 & 1.3 & 1.7 & 1.0 & 2.3 \\
\hline F. hexaseptatum & InaCC F866 & 1.0 & 1.7 & NA & NA & 1.3 & 1.7 & 4.7 & 4.7 \\
\hline F. purpurascens & InaCC F886 & 1.0 & 2.0 & NA & NA & 1.3 & 2.0 & 3.7 & 3.3 \\
\hline F. phialophorum & InaCC F844 & 1.0 & 2.0 & NA & NA & 1.7 & 2.0 & 3.3 & 2.3 \\
\hline F. grosmichelii & InaCC F820 & 2.3 & 2.3 & NA & NA & 1.0 & 1.3 & 4.0 & 3.3 \\
\hline \multirow[t]{8}{*}{ F. odoratissium } & InaCC F891 & 1.0 & 2.0 & 1.3 & 2.0 & 2.7 & 3.0 & 4.0 & 5.0 \\
\hline & InaCC F817 & 1.0 & 2.0 & NA & NA & 3.6 & 3.3 & 4.5 & 4.5 \\
\hline & InaCC F997 & 1.0 & 2.3 & NA & NA & 4.8 & 4.7 & 4.0 & 5.0 \\
\hline & INACC F899 & 1.3 & 1.7 & 1.3 & 2.0 & 3.0 & 2.7 & 2.7 & 2.3 \\
\hline & 115 & 1.3 & 1.3 & 1.3 & 2.0 & 3.3 & 2.7 & 3.7 & 3.0 \\
\hline & InaCC F931 & 1.3 & 1.3 & 1.0 & 2.0 & 3.7 & 3.3 & 3.3 & 4.3 \\
\hline & InaCC F856 & 1.3 & 1.7 & 1.3 & 1.3 & 4.0 & 3.0 & 4.3 & 3.7 \\
\hline & InaCC F822 & 1.3 & 1.7 & 1.0 & 1.3 & 4.3 & 3.7 & 4.3 & 3.3 \\
\hline F. oxysporum & CNPMF.R1 & 1.7 & 1.7 & NA & NA & 1.3 & 2.0 & 3.7 & 3.3 \\
\hline
\end{tabular}


Pathogenic diversity of Indonesian Fusarium wilt pathogens

Supplementing table 5. Estimated variance components from the full random model on each experimental setup.

\begin{tabular}{|c|c|c|c|c|}
\hline \multirow[t]{2}{*}{ Random term } & \multicolumn{2}{|c|}{ Corm (C) } & \multicolumn{2}{|c|}{ Foliar (L) } \\
\hline & Component & s.e. & Component & s.e. \\
\hline \multirow{2}{*}{\multicolumn{5}{|c|}{$\begin{array}{l}\text { Experiment 1: } \\
\text { GN }\end{array}$}} \\
\hline & & & & \\
\hline experiment (exper.) & 0.3184 & 0.2043 & 0.1332 & 0.0977 \\
\hline isolates (isol.) & 1.2999 & 0.2739 & 0.6206 & 0.1547 \\
\hline replicates (rep.) & 0.0086 & 0.0097 & 0.0008 & 0.0043 \\
\hline exper.isol & 0.3185 & 0.0643 & 0.4003 & 0.0708 \\
\hline exper.rep & 0.0025 & 0.0083 & 0.0075 & 0.0085 \\
\hline isol.rep & 0.0106 & 0.0258 & 0.0068 & 0.0200 \\
\hline exper.isol.rep & 0.6120 & 0.0437 & 0.4710 & 0.0339 \\
\hline
\end{tabular}

\section{Experiment 2:}

TR4 on GN

\begin{tabular}{lrrrr} 
experiment (exper.) & 0.4679 & 0.3508 & 0.2786 & 0.2279 \\
isolates (isol.) & 0.0300 & 0.0391 & 0.0289 & 0.0681 \\
replicates (rep.) & -0.0080 & 0.0088 & -0.0132 & 0.0060 \\
exper.isol & 0.0657 & 0.0582 & 0.2342 & 0.0940 \\
exper.rep & 0.0249 & 0.0306 & 0.0231 & 0.0251 \\
isol.rep & -0.0797 & 0.0457 & -0.0336 & 0.0473 \\
exper.isol.rep & 0.8320 & 0.0925 & 0.7380 & 0.0849 \\
\hline
\end{tabular}

\section{Experiment 3: \\ GN.GM}

\begin{tabular}{lrrrr} 
varieties (var.) & 0.8365 & 1.2526 & 0.674 & 0.973 \\
isolates (isol.) & 0.4226 & 0.3454 & 0.888 & 0.347 \\
replicates (rep.) & -0.0103 & 0.0161 & 0.013 & 0.012 \\
cult.isol & 1.0088 & 0.3363 & 0.259 & 0.175 \\
cult.rep & 0.0087 & 0.0252 & -0.050 & 0.015 \\
isol.rep & 0.1440 & 0.0840 & -0.200 & 0.142 \\
var.isol.rep & 0.6070 & 0.0929 & 1.517 & 0.229 \\
\hline
\end{tabular}

\section{Experiment 4:}

\section{GN.GM. Rejang. Pahang}

$\begin{array}{lrrrr}\text { varieties (var.) } & 0.8586 & 0.7588 & 0.3913 & 0.3676 \\ \text { isolates (isol.) } & 0.1656 & 0.1533 & 0.0446 & 0.0736 \\ \text { replicates (rep.) } & 0.0044 & 0.0186 & 0.0046 & 0.0340 \\ \text { cult.isol } & 0.6116 & 0.1838 & 0.2610 & 0.1216 \\ \text { cult.rep } & 0.0194 & 0.0294 & 0.0580 & 0.0623 \\ \text { isol.rep } & -0.0090 & 0.0335 & -0.0316 & 0.0514 \\ \text { var.isol.rep } & 0.3950 & 0.0683 & 0.6400 & 0.1110\end{array}$




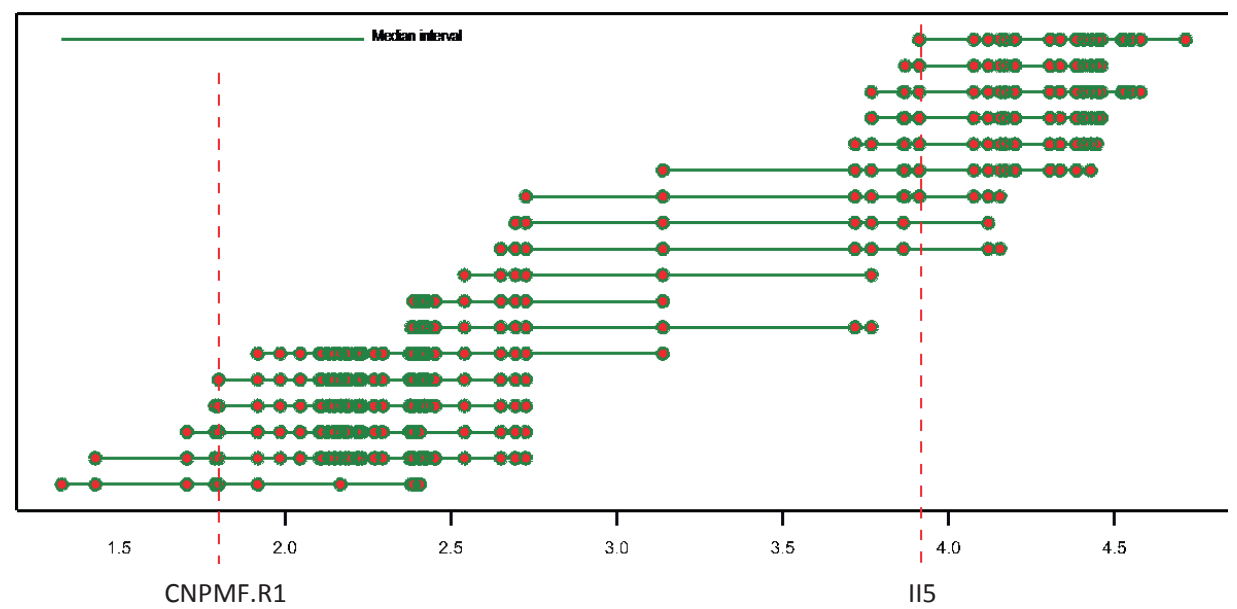

Supplementing Fig. 1. Homogenous subsets of pairwise comparisons of mean corm symptom severities, indicated by connected dots. Each distinct group of means is displayed above each other, on the corm score, based on Fischer's protected LSD. Median LSD size holds for most pairwise comparisons of isolates. II5 strain is used as reference pathogenic group and CNPMF.R1 as non-pathogenic group.

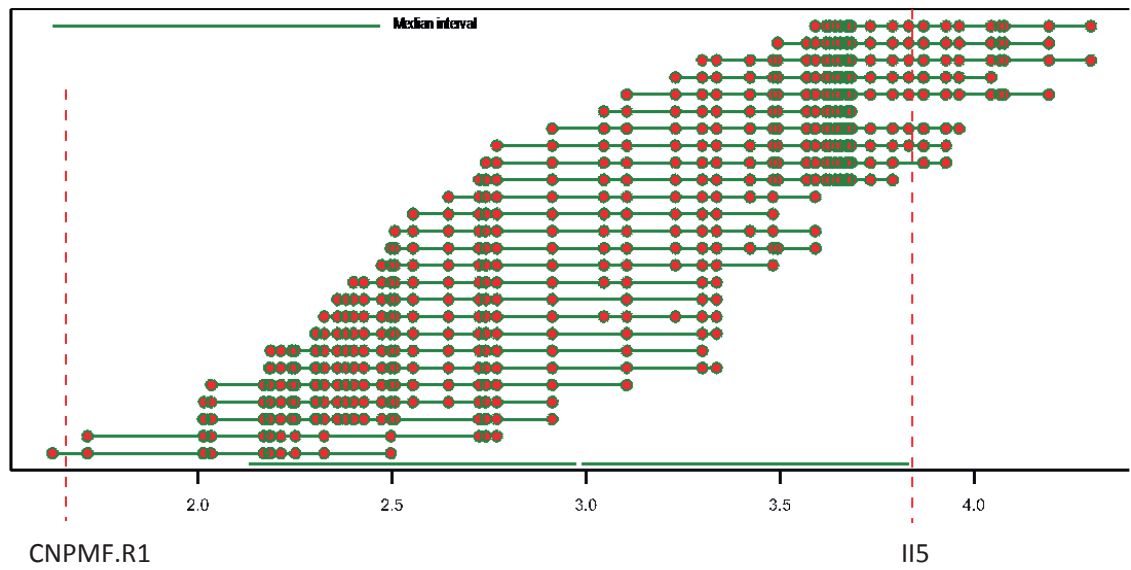

Supplementing Fig. 2. Homogenous subsets of pairwise comparisons of mean foliar symptom severities, indicated by connected dots. Each distinct group of means is displayed above each other, on the corm score, based on Fischer's protected LSD. Median LSD size holds for most pairwise comparisons of isolates. II5 strain is used as reference pathogenic group and CNPMF.R1 as non-pathogenic group. 


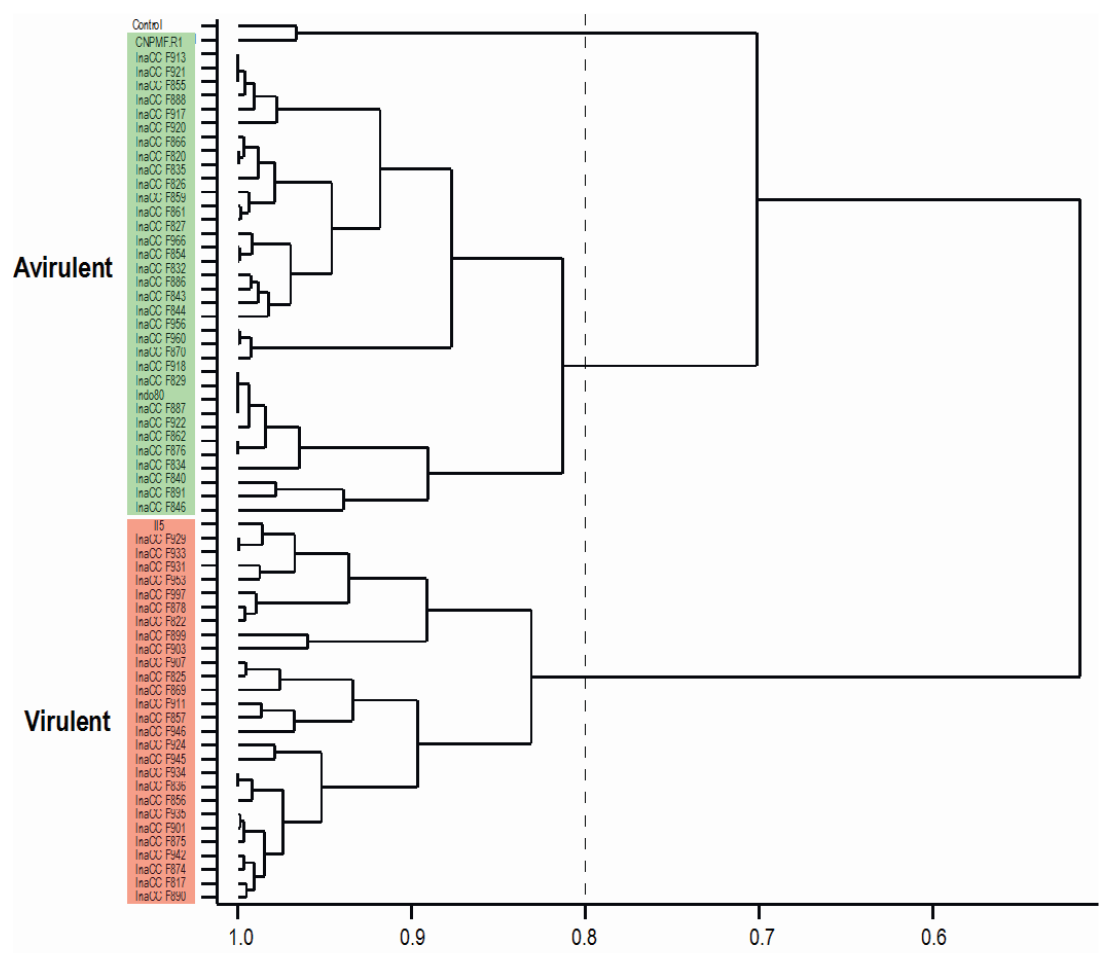

Supplementing Fig. 3. Hierarchical cluster analysis of 63 Fusarium spp. (experiment 1) that were phenotyped (eight weeks after inoculation) on Grand Naine banana plants using averages of Fusarium wilt disease severities in the foliar symptom. Mean values were obtained from the Best Linear Unbiased Predictions (BLUP's, see materials and methods). X-axis values indicate the degree of similarity based on pairwise difference. The vertical dashed line is an arbitrary threshold between significantly different virulence levels of the phenotyped isolates indicated by different colours. 


\title{
Chapter 5
}

\section{New endemic Fusarium species hitchhiking with pathogenic Fusarium strains causing Panama disease in small-holder banana plots in Indonesia}

\author{
Nani Maryani ${ }^{1,2,3}$, Marcelo Sandoval- Denis ${ }^{4,5}$, Lorenzo Lombard ${ }^{4}$, Pedro W. Crous ${ }^{4}$, \\ and Gerrit H.J. Kema ${ }^{1,2}$
}

\begin{abstract}
'Biointeractions and Plant Health, Wageningen Plant Research, Wageningen University and Research, Wageningen, The Netherlands; 'Laboratory of Phytopathology, Wageningen University and Research, Wageningen, The Netherlands; ${ }^{3}$ Biology Education, Faculty of Education, Universitas Sultan Ageng Tirtayasa (UNTIRTA), Banten, Indonesia; ${ }^{4}$ Westerdijk Fungal Biodiversity Institute, Utrecht, The Netherlands; ${ }^{5}$ Faculty of Natural and Agricultural Sciences, Department of Plant Sciences, University of the Free State, South Africa.
\end{abstract}

Submitted 


\begin{abstract}
Fusarium species are well known for their abundance, diversity and cosmopolitan life style. Many members of the genus Fusarium are associated with plant hosts, either as plant pathogens, secondary invaders, saprotrophs, and/or endophytes. We previously studied the diversity of Fusarium species in the Fusarium oxysporum species complex (FOSC) associated with Fusarium wilt of banana in Indonesia. In that study, several Fusarium species not belonging to the FOSC were found to be associated with Fusarium wilt of banana. These Fusarium isolates belonged to three Fusarium species complexes, which included the Fusarium fujikuroi species complex (FFSC), Fusarium incarnatum-equiseti species complex (FIESC) and the Fusarium sambucinum species complex (FSSC). Using a multi-gene phylogeny that included partial fragments of the beta-tubulin (tub), calmodulin ( $c m d A)$, translation elongation factor 1-alpha (tef1), the internal transcribed spacer region of the rDNA (ITS), the large subunit of the rDNA (LSU), plus the RNA polymerase II large subunit ( $r p b 1$ ) and second largest subunit ( $r p b 2$ ) genes, we were able to identify and characterize several of these as new Fusarium species in the respective species complexes identified in this study.
\end{abstract}

Key words: Indonesia, new species, non-pathogenic, phylogeny, species complex 


\section{INTRODUCTION}

Fusarium is one of the most diverse fungal genera that has been given much attention by mycologists and plant pathologists (Snyder \& Hansen 1940, Nelson et al. 1983, Geiser et al. 2013, Aoki et al. 2014). Its global distribution, ability to adapt to manifold climatic conditions, and colonisation of a wide number of ecological niches and hosts, makes the diversity and abundance of Fusarium species unparalleled (Booth 1971, Gerlach \& Nirenberg 1982, Geiser et al. 2013, Aoki et al. 2014). The genus Fusarium includes some of the most devastating plant pathogens, affecting many agronomical crops. Two of its species, Fusarium graminearum and F. oxysporum, were included in the top 10 list of fungal plant pathogens regarded as important in terms of scientific and economic impact (Dean et al. 2012, Geiser et al. 2013, Aoki et al. 2014).

Besides their role as plant pathogens, Fusarium species are also known as endophytes or saprophytic colonisers (Leslie et al. 1990, Bacon \& Yates 2000). Many different Fusarium species are associated with symptomatic and asymptomatic plants (Leslie et al. 1990, Wang et al. 2004, Pinaria et al. 2010). Their role as pathogens can easily be identified through pathogenicity tests. However, many Fusarium species have not been associated with any disease symptoms on plants (Wang et al. 2004, Pinaria et al. 2010). Therefore, they are considered as endophytes and their association with their known host plants is difficult to discern (Kuldau \& Yates 2000).

A complex of Fusarium spp. in the Fusarium oxysporum species complex (FOSC) is causing Fusarium wilt on banana (Maryani et al. 2019), also known as Panama disease (Stover 1962). The ability of these notorious fungi to infect a wide range of banana varieties has resulted in substantial economic strive in several banana producing regions (Ploetz et al. 2015, http://fusariumwilt.org/). Several studies acknowledged the diversity of Fusarium spp. pathogenic on banana and their worldwide distribution, thus recognising the threat to global banana cultivation (Ploetz 2006a, Ordonez et al. 2015, Maryani et al. 2019). However, to our knowledge, no study has been done to assess which other Fusarium species might be associated with Fusarium wilt on bananas.

In this study, we report Fusarium species hitchhiking with pathogenic Fusarium spp. causing Panama disease, isolated from local banana varieties in Indonesia. Therefore, we aim to characterise these non-Fusarium oxysporum isolates, based on multi-gene phylogenetic inference, supported by morphological observations. 


\section{MATERIALS AND METHODS}

\section{Isolates}

Isolates were obtained from the pseudostems of local banana plants clearly displaying symptoms of Fusarium wilt, which were sampled in small-holder backyard plantations across Indonesia in 2014-2015 (Maryani et al. 2019). The dried pseudostem samples were cut into pieces of $2 \times 3 \mathrm{~cm}$ and plated on Komada medium (Komada 1975). Single-spore isolates were derived from resulting fungal colonies, and transferred to potato dextrose agar (PDA), on which they were maintained as working cultures, or stored in $20 \%(\mathrm{v} / \mathrm{v})$ glycerol at $-80^{\circ} \mathrm{C}$ for long term preservation. All isolates were deposited in the Indonesian Culture Collection (InaCC) Cibinong, Indonesia.

\section{Morphological characterisation}

Morphological characterisations of the Fusarium species were performed on PDA for colony growth rates, pigmentation and production of aerial conidia; carnation leaf agar (CLA; Fisher et al. 1982) for formation of sporodochia and sporodochial conidia, and synthetic low-nutrient agar (SNA; Nirenberg 1981) for chlamydospores. To induce sporulation, cultures were incubated under continuous white light (Osram L18W/840 Cool White) for $7 \mathrm{~d}$ at $25^{\circ} \mathrm{C}$. Growth rates of all isolates were determined on PDA after $7 \mathrm{~d}$ incubation at $25^{\circ} \mathrm{C}$ in the dark. Colony colour notation followed the mycological colour charts of Rayner (1970). Morphological characters were examined after mounting fungal structures in sterile water and observed using light microscopy (Nikon Eclipse 80i microscope) with Differential Interference Contrast (DIC) optics and a Nikon AZ100 stereomicroscope, both equipped with Nikon DS-Ri2 high definition colour digital cameras. Photographs and measurements were taken using the Nikon software NIS-elements D software v. 4.50. The length and width of at least 30 conidiogenous cells and 50 conidia were measured, and the mean values, standard deviation (SD) with maximum-minimum values were calculated. All descriptions, illustrations and nomenclatural data were deposited in MycoBank (Crous et al. 2004).

\section{DNA isolation, amplification and analyses}

Genomic DNA was isolated using the DNA Wizard Magnetic DNA Purification System for Food kit (Promega, USA). Partial gene sequences were determined for the RNA polymerase largest subunit gene ( $r p b 1$ ) using primers RPB1-Fa \& RPB1-G2R (O'Donnell et al. 2010), RNA polymerase second largest subunit gene ( $r p b 2)$ using primers RPB2-5f2 \& RPB2-7cr (O'Donnell et al. 2010), the translation elongation factor 1-alpha gene (tef1) using primers EF1 \& EF2 (O'Donnell et al. 1998a), calmodulin (cmdA) CAL-228F \& CAL-2RD (Carbone \& Kohn 1999, Quaedvlieg et al. 2011), beta-tubulin (tub) using primers TUB-T1 \& TUB-4RD (O'Donnell \& Cigelnik 1997, Woudenberg et al. 2009), the internal transcribed spacer region (ITS) using primers ITS4 \& ITS5 (White et al. 1990) and the large subunit of the ribosomal DNA (LSU) using 
primers LROR \& LR5 (Rehner \& Samuels 1994, Vilgalys \& Hester 1990). PCR conditions followed those described by Lombard et al. (2015). Amplicons were sequenced in both directions using the same primer pairs as were used for amplification to ensure integrity of the sequences. Consensus sequences were analysed and assembled using MEGA v. 7 (Kumar et al. 2016). Subsequent alignments for each individual locus were generated using MAFFT v. 7.110 (Katoh et al. 2017) and manually corrected if necessary. The individual sequences generated in this study were compared with those maintained in the Fusarium-MLST database (http://www.westerdijkinstitute.nl/fusarium/) and GenBank, and relevant sequences were included in the subsequent phylogenetic inferences.

Phylogenetic analyses were based on Maximum Likelihood (ML) and Bayesian Inference (BI). The ML analysis was performed using RAxML v. 8 (randomised accelerated (sic) maximum likelihood for high performance computing) (Stamatakis 2014) through RAxML BlackBox (http://embnet.vital-it.ch/raxml-bb/index.php) or the CIPRES science gateway portal (Miller et al. 2012). To assess the robustness of the analyses, the Bootstrap support (BS) was determined automatically by the software using default parameters. The $\mathrm{BI}$ analysis was performed using MrBayes v. 3.2.6 (Ronquist et al. 2012) on the CIPRES science gateway portal (Miller et al. 2012), using four Markov chain Monte Carlo (MCMC) chains starting from a random tree topology. The MCMC analyses lasted until the average standard deviations of split frequencies were below 0.01 with phylogenies saved every 1000 generations. The first $25 \%$ of saved trees were discarded as the "burn-in" phase and the $50 \%$ consensus trees and posterior probabilities (PP) were determined from the remaining trees. All the sequences generated in this study were deposited in GenBank and the European Nucleotide Archive (ENA) and the alignments in TreeBASE.

\section{Pathogenicity}

Representative isolates from the different Fusarium species were selected for pathogenicity assays. Fusarium odoratissimum, Tropical Race 4 (TR4) isolate InaCC F856, was used as a positive control, and negative controls were treated with sterile water only. Two to threemonth-old banana plants of the Cavendish variety Grand Naine were used in greenhousecontrolled conditions (constant day temperature of $25{ }^{\circ} \mathrm{C}$, night temperature of $23{ }^{\circ} \mathrm{C}$, ambient light until max. $16 \mathrm{~h}$, and a relative humidity of $\geq 75 \%$ ). Preparation of the fungal inoculum, pathogenicity tests and severity scoring followed the protocol of Maryani et al. (2019). Five plant replicates were included for each isolate tested and $7 \mathrm{wk}$ after inoculation disease severity was evaluated by scoring external foliage and internal corm symptoms. 


\section{RESULTS}

In total, 20 isolates were identified that did not belong to the Fusarium oxysporum species complex (FOSC). These isolates were recovered from 13 banana varieties from the islands of Flores, Java, Kalimantan and Sulawesi (Table 1). An initial preliminary phylogenetic inference based on $r p b 2$ sequence data, demonstrated that most isolates belonged to the Fusarium incarnatum-equiseti species complex (FIESC, 11 isolates), followed by the F. fujikuroi species complex (FFSC, eight isolates) and the F. sambucinum species complex (FSSC, one isolate) (Fig. 1). Nine isolates in FIESC originated from Kalimantan, isolated from Musa sp. variety Pisang Awak (ABB), Pisang Kepok (ABB), and Pisang Talas $(A A)$ and two isolates from Sulawesi, isolated from Musa acuminata var. Pisang Cere (AAA). The majority of the isolates in FFSC were isolated from bananas varieties in Java. The only isolate in the FSSC was isolated from the variety Pisang Awak (ABB) in Central Kalimantan. Fusarium isolates belonging to different species complexes were in some cases recovered from the same sample: isolate InaCC F962 in the FFSC and isolate Indo175 in the FIESC were isolated from the same sample of Musa acuminata var. Pisang Talas (AA) from South Kalimantan. In the FFSC, isolate InaCC F993 and Indo 213 were also isolated from a sample of Musa acuminata var. Pisang Mas Kirana (AA) from East Java. Additionally, different banana varieties were found to be associated with the same Fusarium species (Table 1).

\section{Fusarium fujikuroi species complex (FFSC) phylogeny - Fig. 2.}

The eight isolates belonging to the FFSC were further analysed using a multi-gene phylogeny based on $c m d A, r p b 1, r p b 2$, tef and tub. The final alignment included 4791 characters (cmdA 544, rpb1 1533, rpb2 1550, tef 676 and tub 488) including alignment gaps, and encompassed 52 isolates, with two outgroup taxa ( $F$. oxysporum CBS 716.74 and CBS 744.97) (Table 2). The analysis was consistently able to distinguish the three biogeographical clades known as the African, American and Asian clades sensu O'Donnell et al. (1998). All of the Indonesian isolates clustered within the Asian clade of FFSC except for isolate InaCC F991, identified as F. verticilloides, and clustered within the African clade (Fig. 2). According to the multi-gene analysis, two isolates (InaCC F962 and InaCC F992) were identified as F. proliferatum, while two new phylogenetic species were recognised among the Indonesian isolates. Isolates InaCC F872 and InaCC F993, from central and East Java, respectively, clustered in a distinct, highly supported clade ( $96 \mathrm{bs} / 0.99 \mathrm{pp}$ ) closely related to $F$. mangiferae. Isolates InaCC F950-152, formed a distinct group (100 bs/1.0 pp), closely related to, but genetically distinct from $F$. sacchari. 


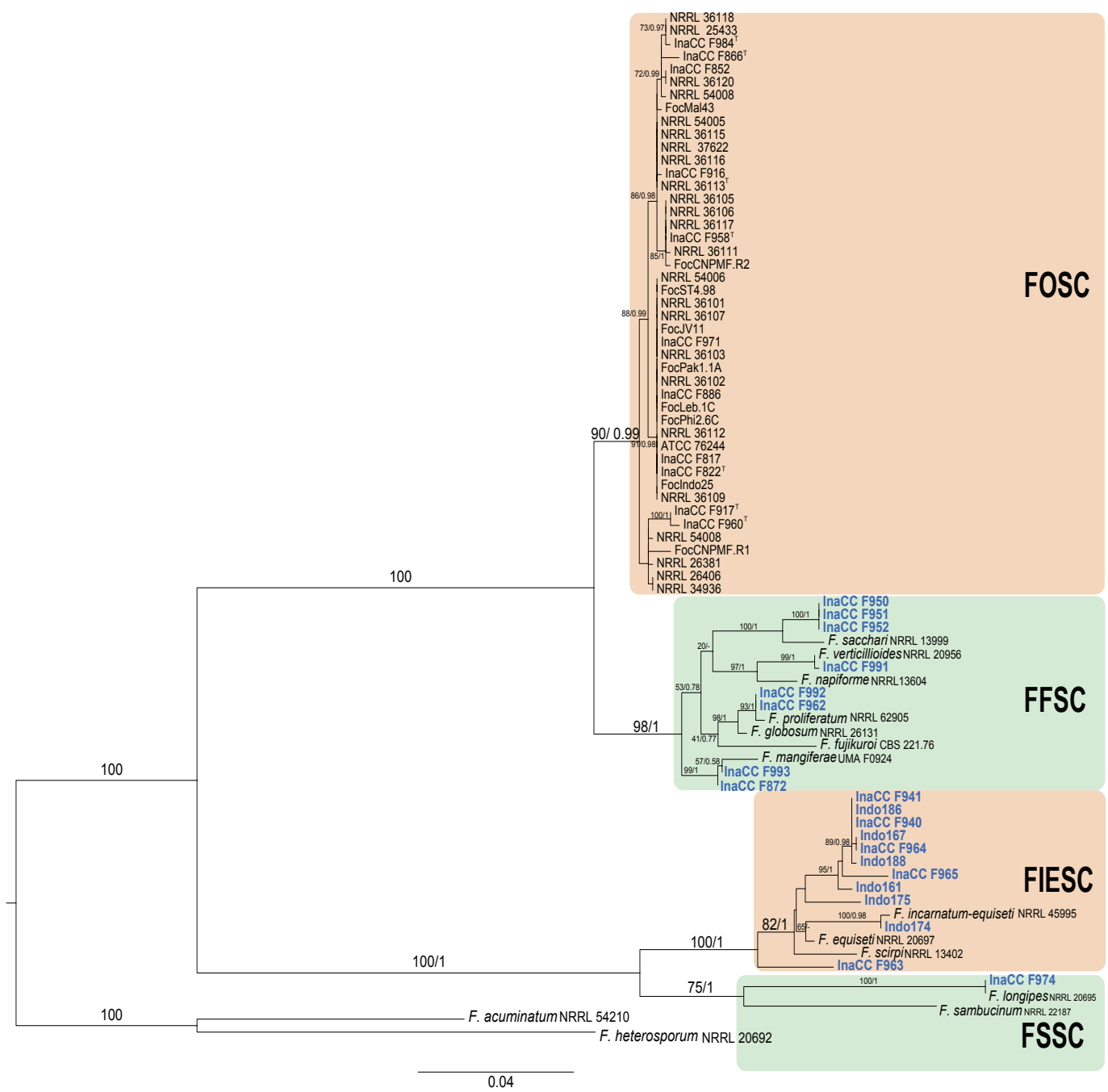

Fig. 1. Maximum Likelihood tree inferred using the $r p b 2$ gene region of the Indonesian isolates in the Fusarium fujikuroi species complex (FFSC), Fusarium incarnatum-equiseti species complex (FIESC), Fusarium sambucinum species complex (FSSC) and Fusarium oxysporum species complex (FOSC) isolates from a previous study (Maryani et al. 2019). Bootstrap support values and Bayesian posterior probabilities are given at each node. The tree is rooted to Fusarium acuminatum (NRRL 54210) and Fusarium heterosporum (NRRL 20692). 


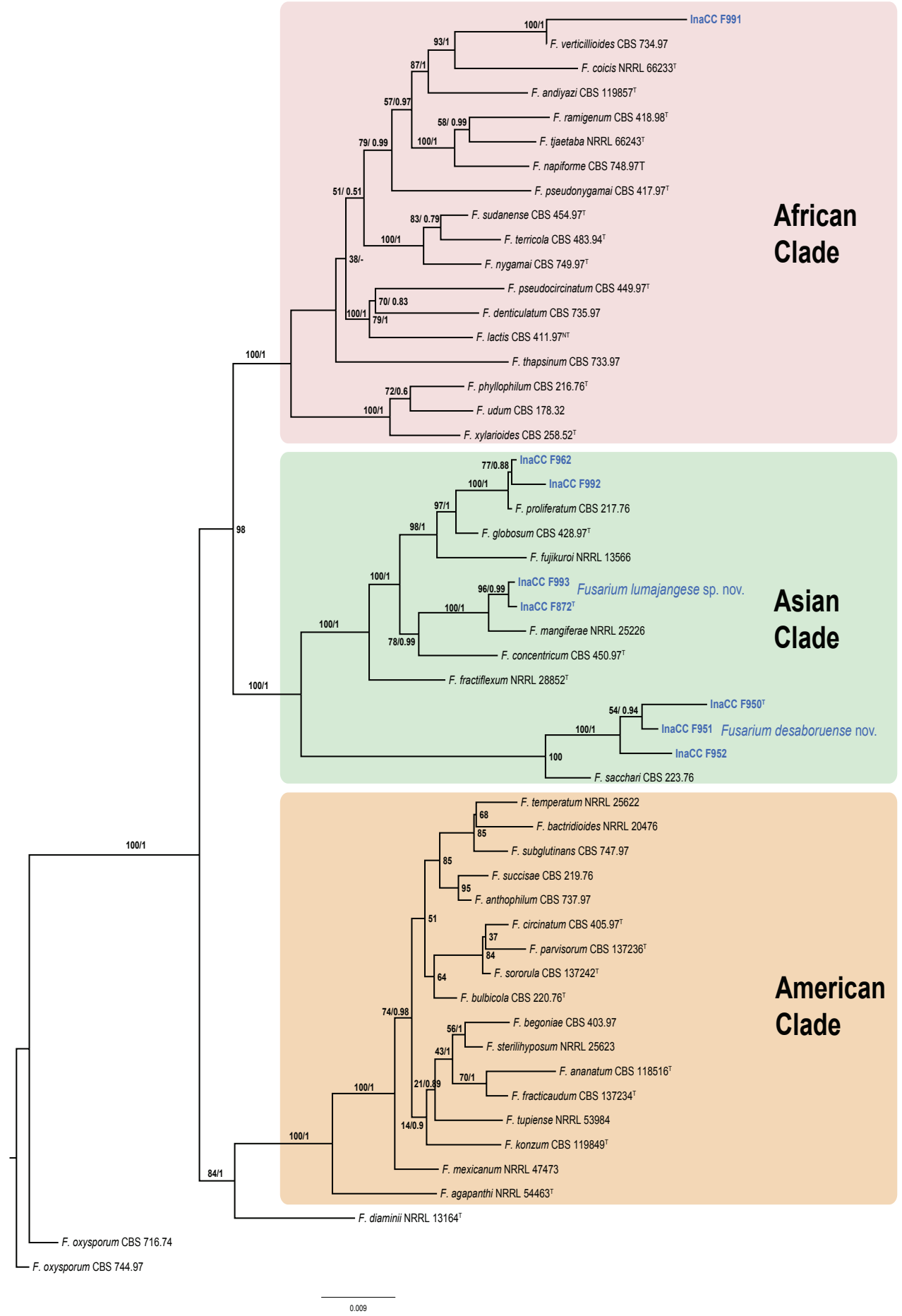

Fig. 2. Maximum likelihood tree inferred from the combined $c m d A$, tef1, $t u b, r p b 1$ and $r p b 2$ sequence datasets of the Fusarium fujikuroi species complex (FFSC) including eight Indonesian isolates (Indicated in blue). Bootstrap support values and Bayesian posterior probabilities are given at each node. The tree is rooted to Fusarium oxysporum (CBS 716.74 and CBS 744.97). 


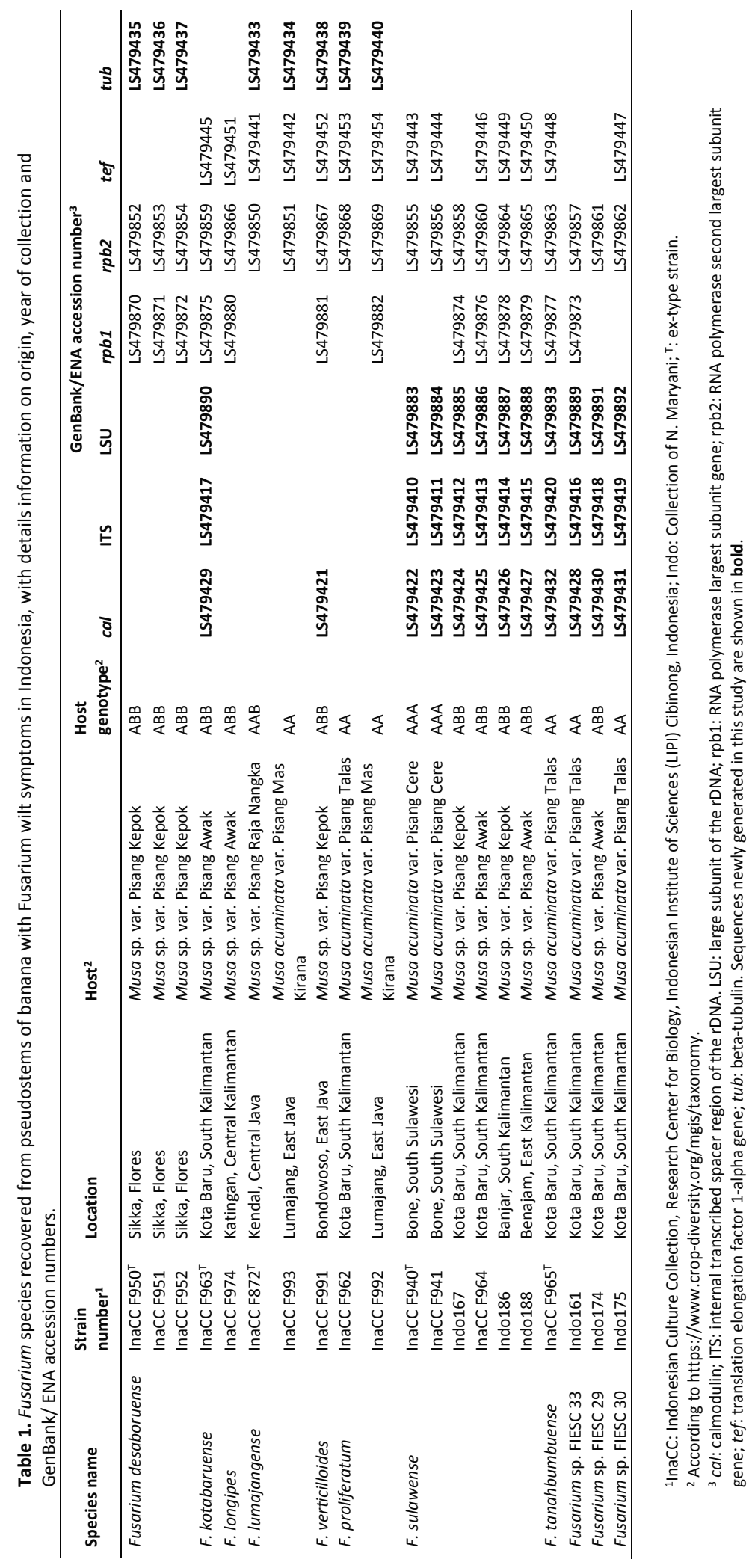


Fusarium species hitchhiking with pathogenic Fusarium in banana

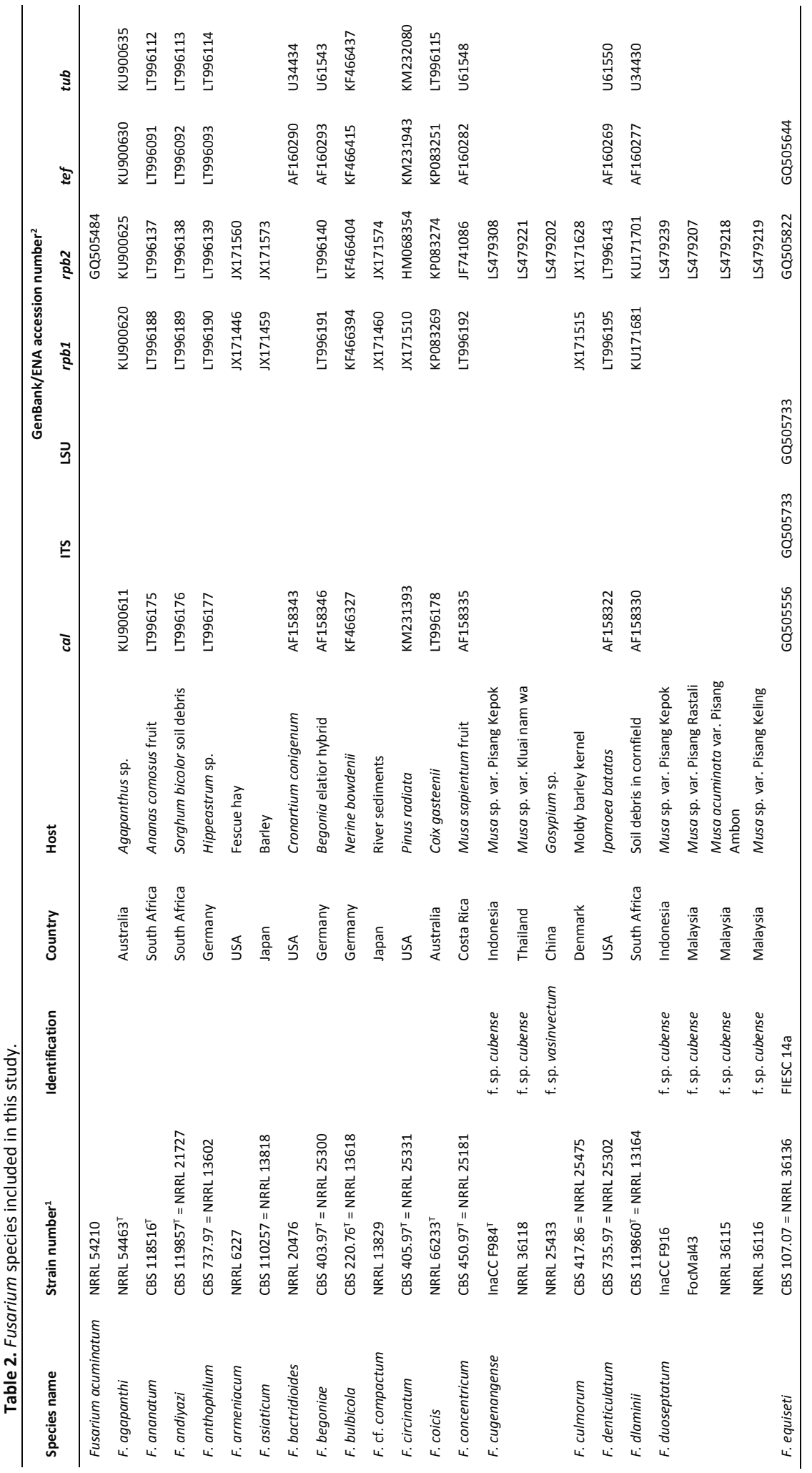




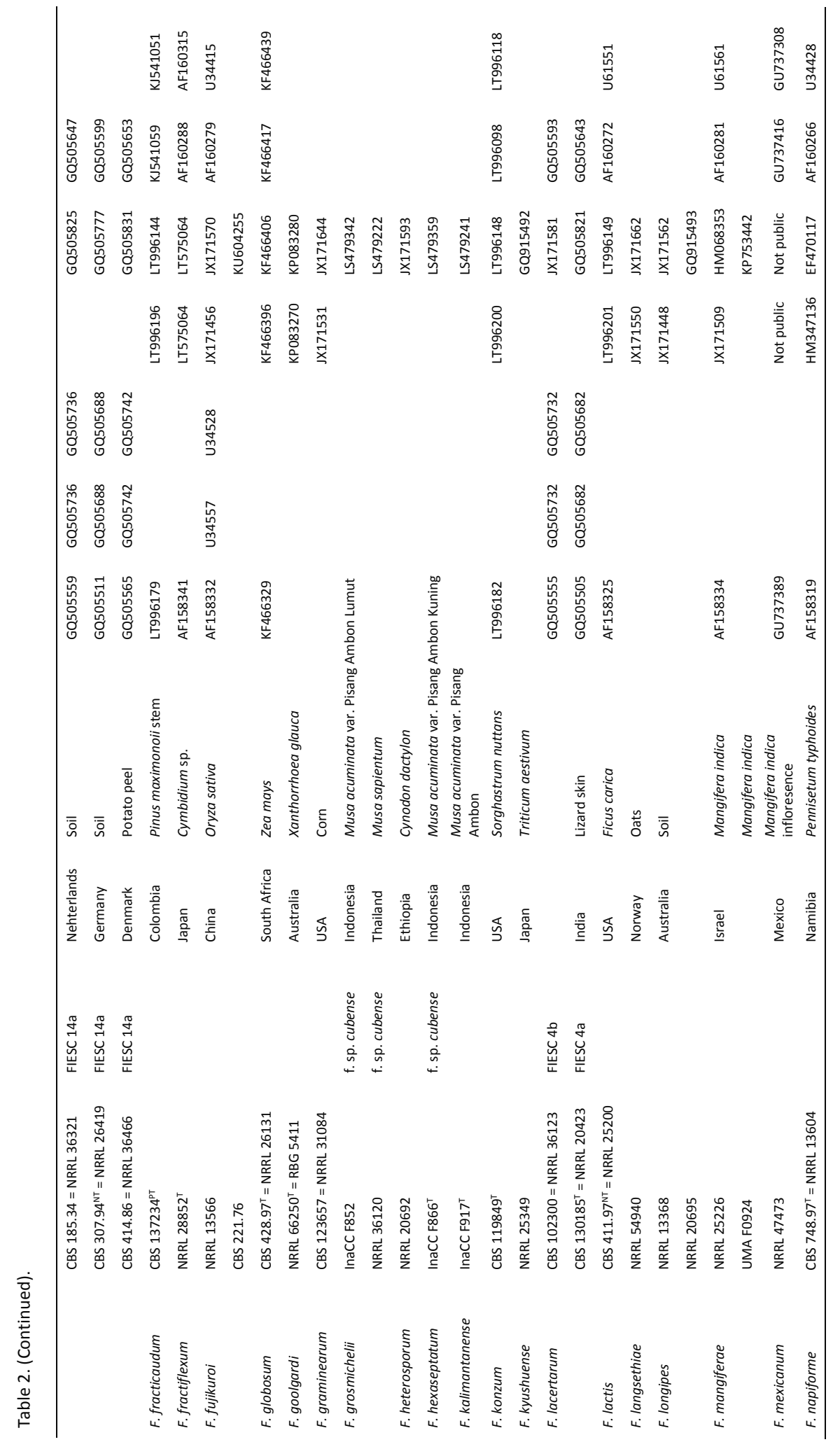


Fusarium species hitchhiking with pathogenic Fusarium in banana

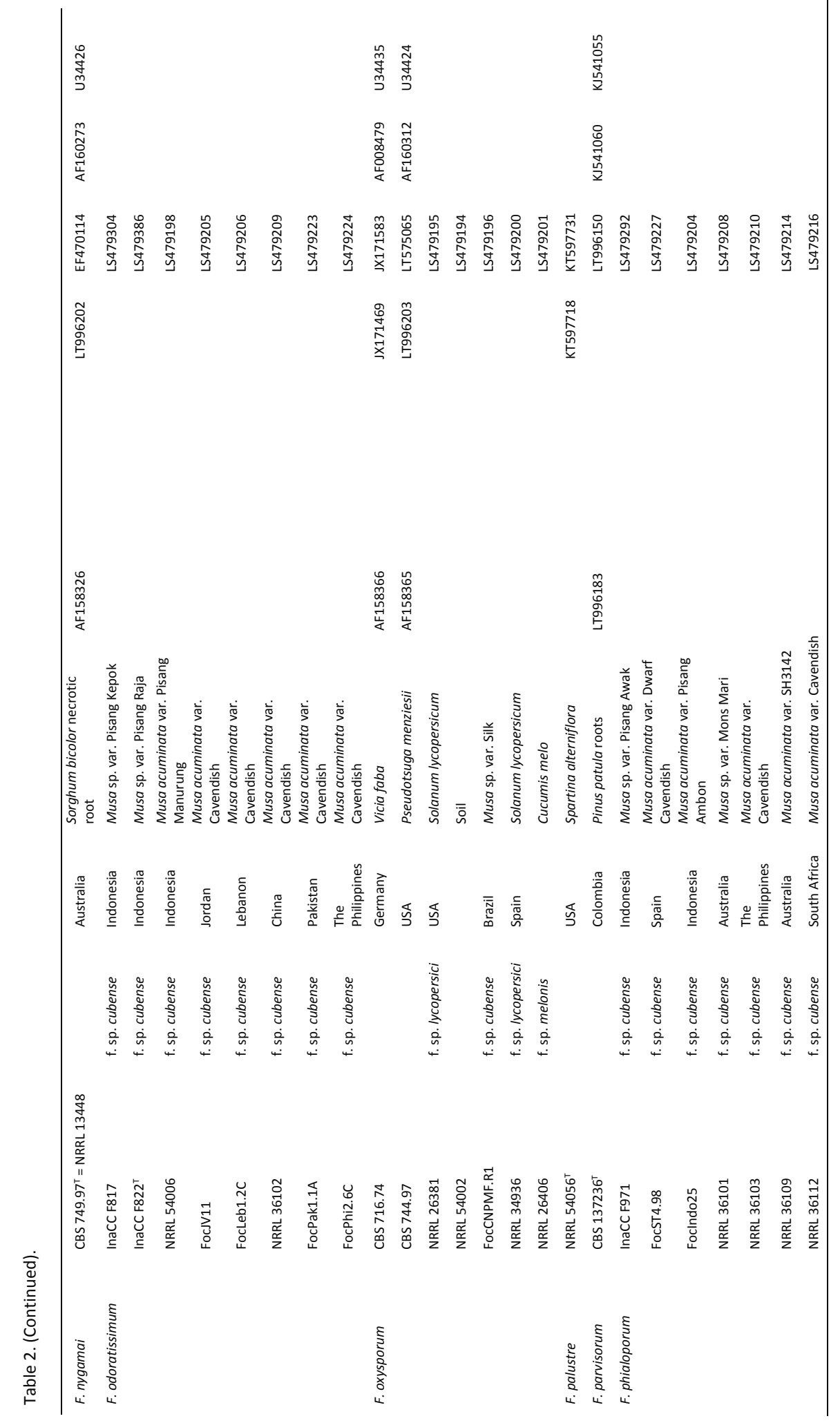




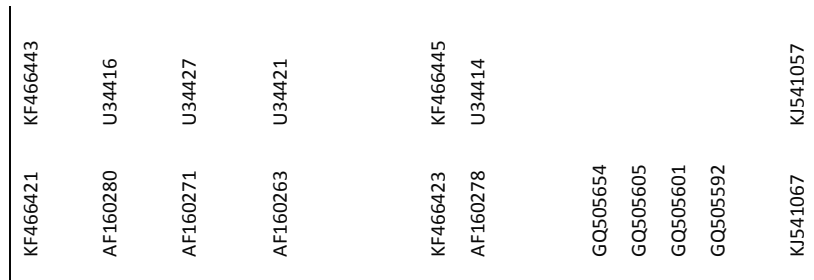

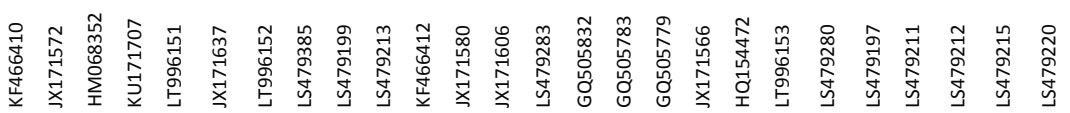

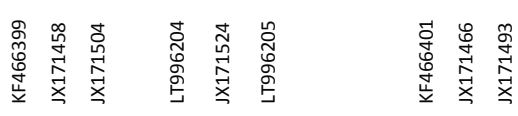

$\stackrel{0}{0}$
$\stackrel{0}{\circ}$
$\stackrel{\circ}{\Xi}$

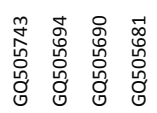

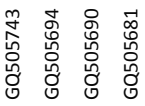

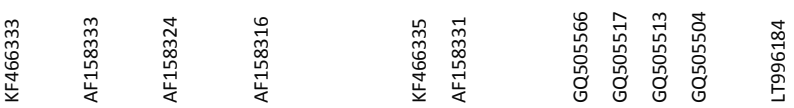

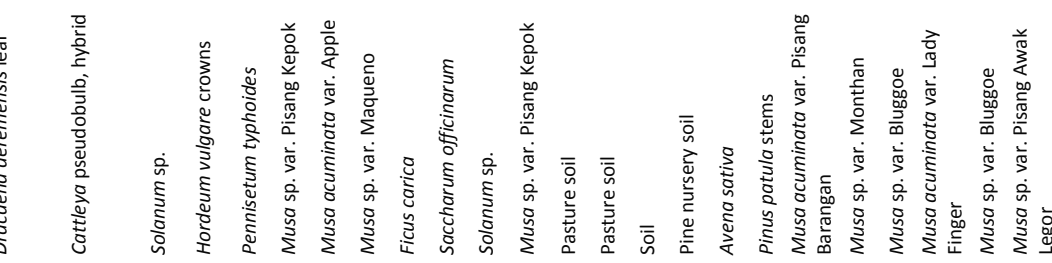

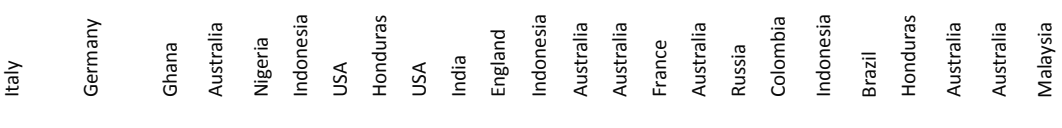

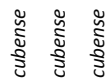

in

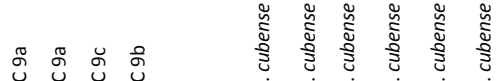

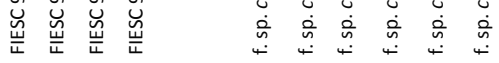

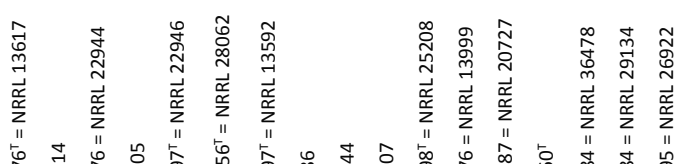

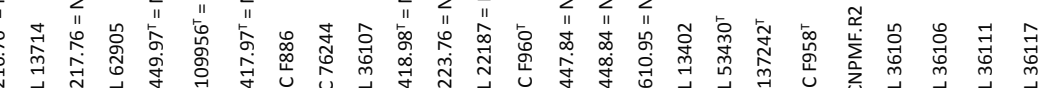

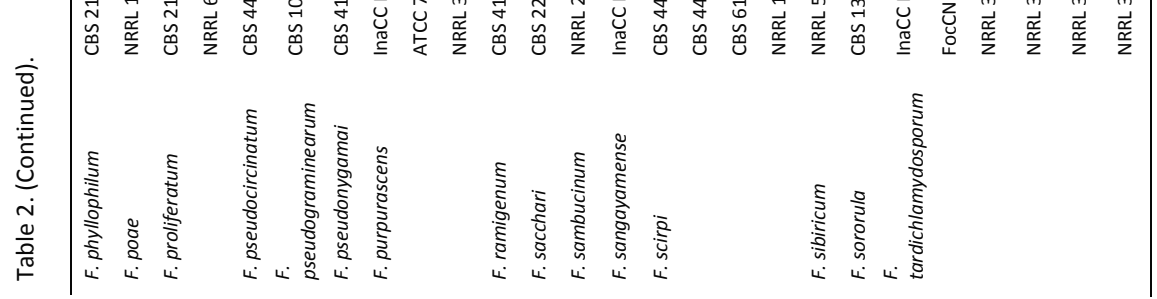


Fusarium species hitchhiking with pathogenic Fusarium in banana

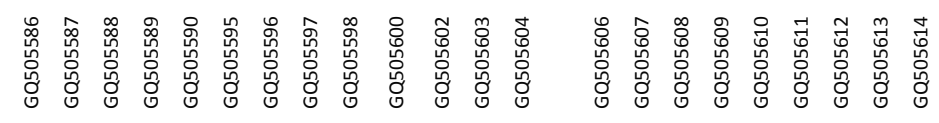

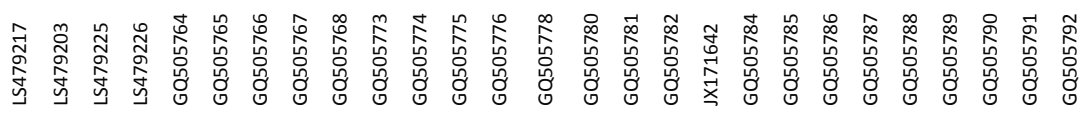

$$
\text { 芯 }
$$

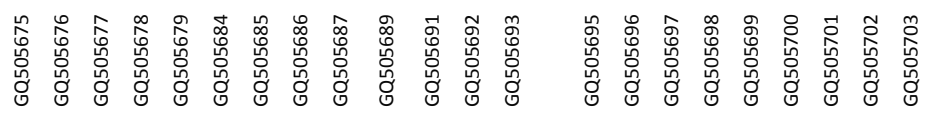

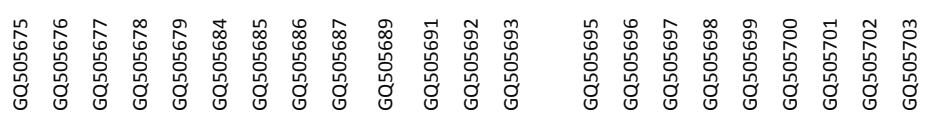

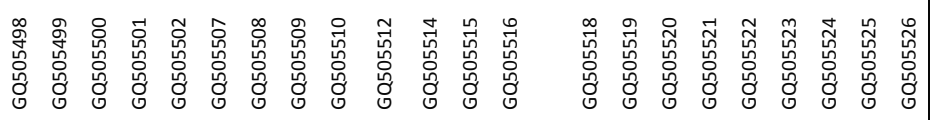

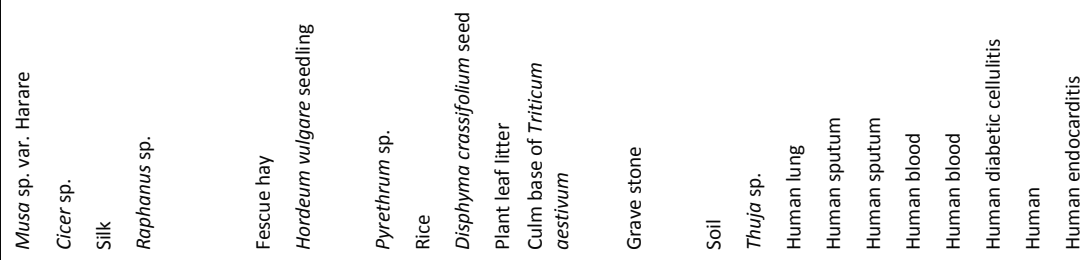

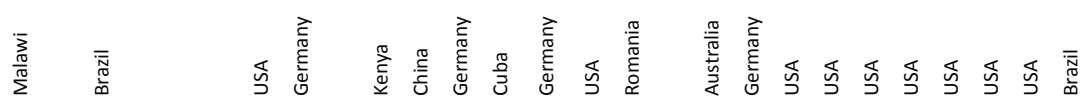
蒡

产 施

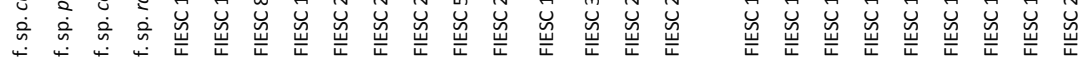

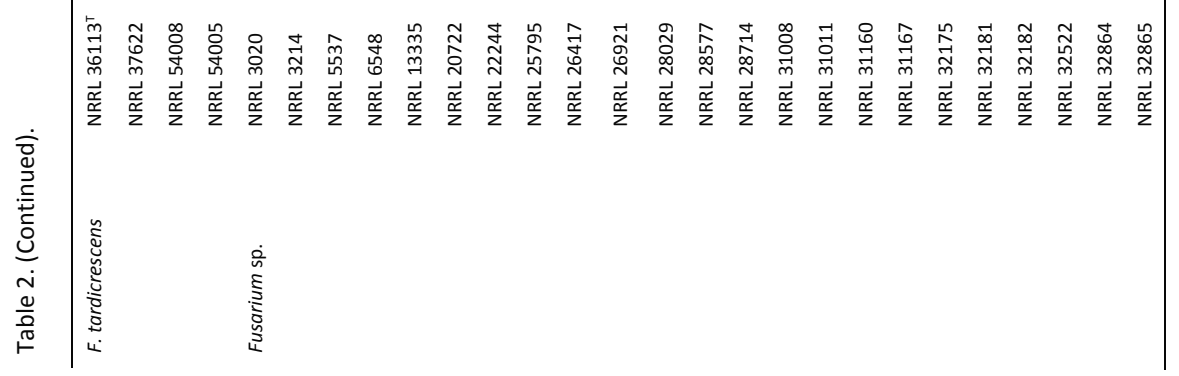




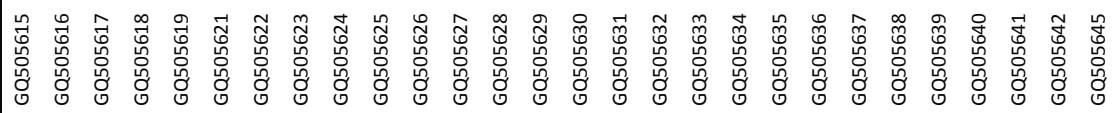

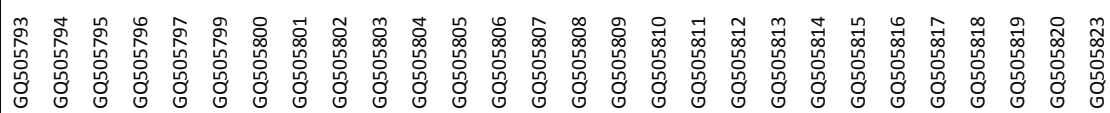

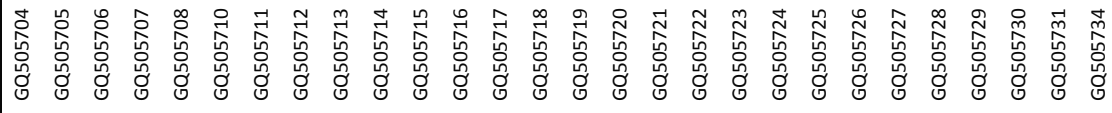

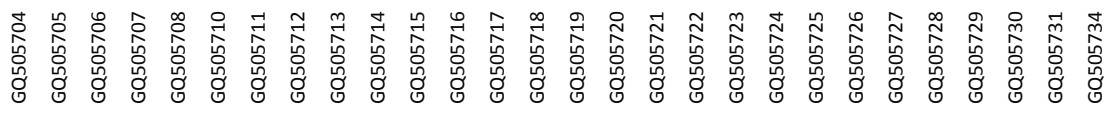

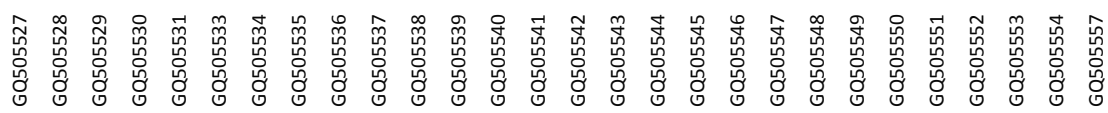

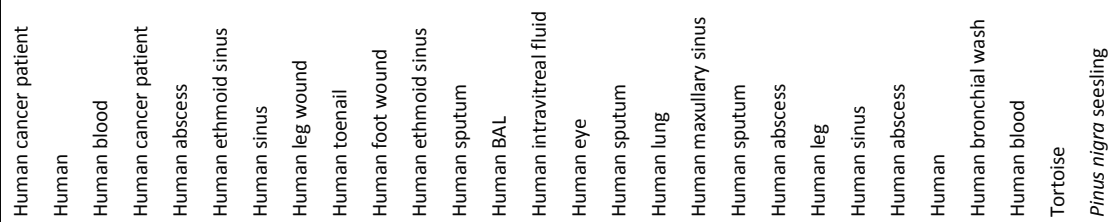

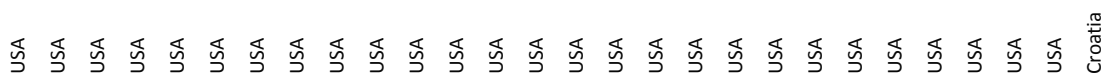

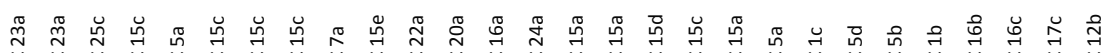

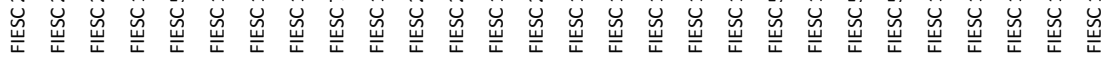

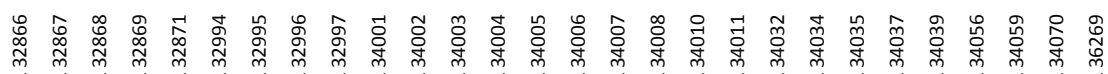

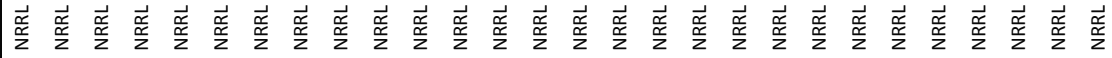


Fusarium species hitchhiking with pathogenic Fusarium in banana

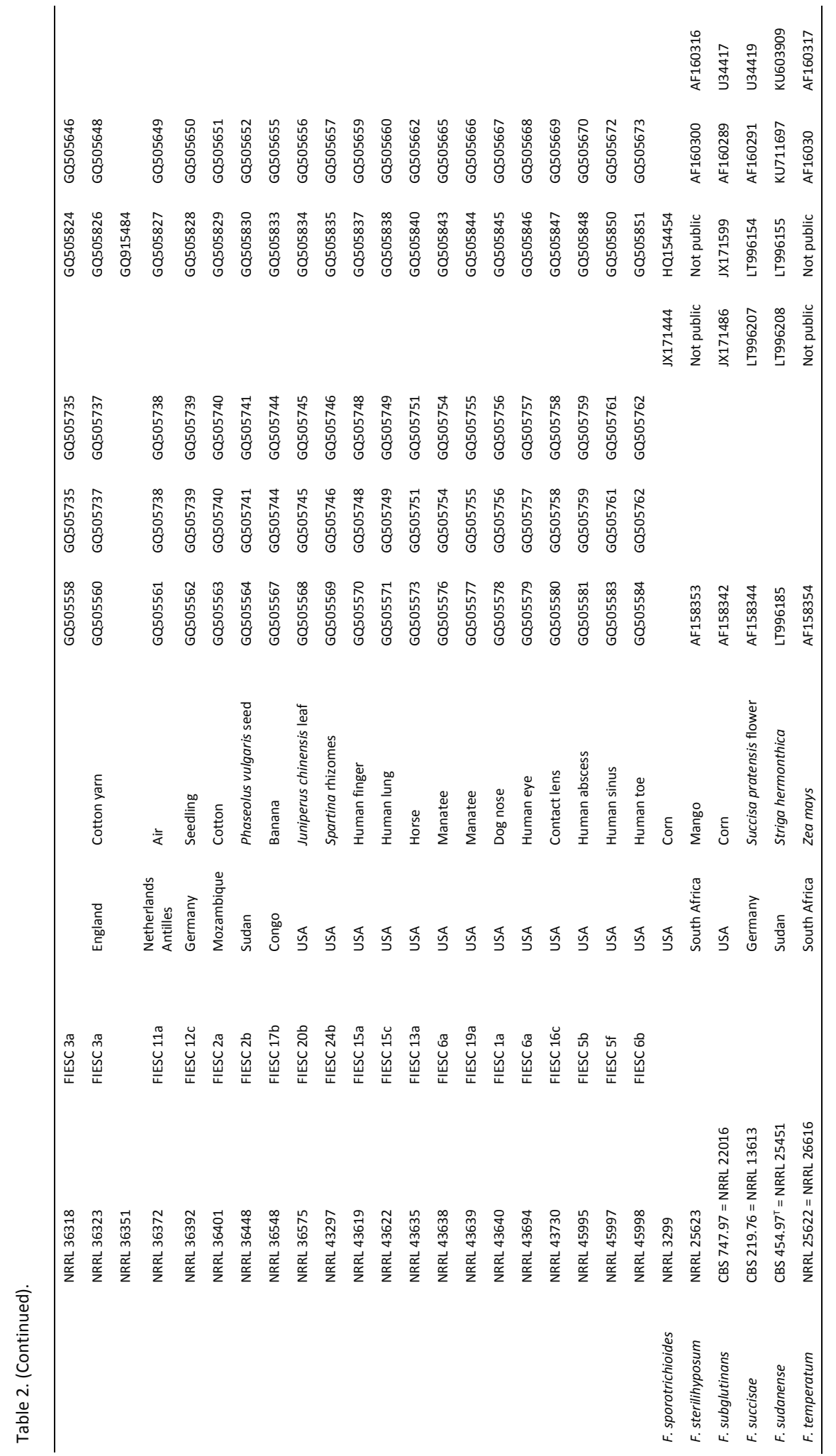




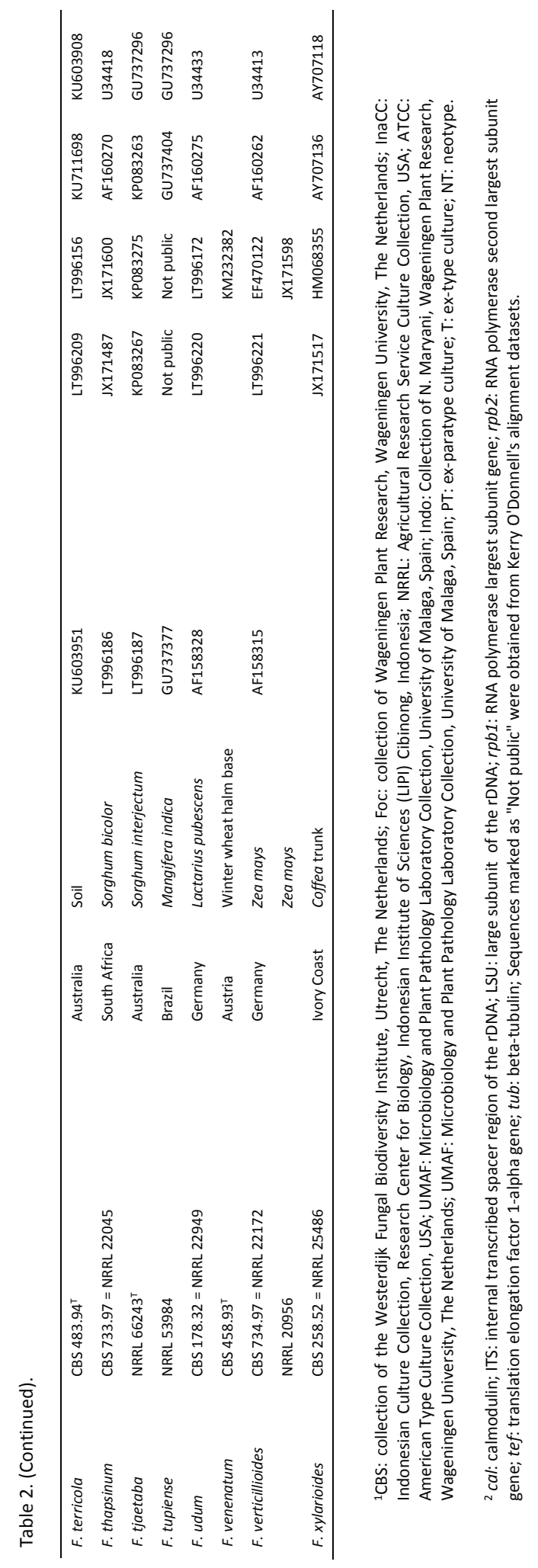




\section{Fusarium incarnatum-equiseti species complex (FIESC) phylogeny - Fig. 3.}

The 11 isolates belonging to the FIESC were assessed using a more inclusive analysis based on five loci ( $c m d A$, ITS, LSU, rpb2 and tef1). The alignment consisted of a total 2746 characters (cmdA 653, ITS 510, LSU 562, rpb2 597 and tef1 424), from 93 isolates, including all the phylogenetic clades known in this species complex plus two outgroup taxa (Fusarium circinatum NRRL 25331 and F. fujikuroi NRRL 13566). Multi-gene phylogenetic inference was able to recognise six new phylogenetic species in the FIESC. The number of new phylogenetic species recognised is equally distributed in the incarnatum clade and the equiseti clade (three new phylospecies each) sensu O'Donnell et al. (2009). In the incarnatum clade, isolates InaCC F940, InaCC F941, Indo167, InaCC F964, Indo186, and Indo188 clustered in a distinct clade (55 $\mathrm{bp} / 0.99 \mathrm{pp}$ ) closely related to the phylogenetic species FIESC-16 which is introduced here as phylogenetic species FIESC-32. These isolates were obtained from five different banana variety hosts in Sulawesi and Kalimantan. The other two new species in the incarnatum clade are monotypic lineages represented by isolate Indo161 (99 bp/1 pp) closely related to FIESC26 and isolate InaCC F965 (50bp/ 1 pp) closely related to FIESC-24, introduced as phylogenetic species FIESC-33 and FIESC-34 respectively. In the equiseti clade, three isolates: Indo174 (99 bp/1 pp) closely related to FIESC-1; Indo175 (-/ 1 pp) and InaCC F963 (55 bp/1 pp), both isolates closely related to FIESC-13, formed monotypic lineages which are introduced here as FIESC-29, FIESC-30, and FIESC-31 respectively. These phylogenetic species were isolated from two banana varieties in relatively close proximity in South Kalimantan.

\section{Fusarium sambucinum species complex (FSSC) phylogeny - Fig. 4.}

The single Indonesian isolate in the FSSC was further analysed using a two-gene phylogeny based on $r p b 1$ and $r p b 2$ sequences. The analysis included a total of 2461 characters (rpb1 854 and rpb2 1607) from a total of 21 isolates representing the FSSC and two outgroup taxa (F. circinatum NRRL 25331 and F. fujikuroi NRRL 13566). Isolate InaCC F974 was identified as Fusarium longipes (Fig. 4) based on phylogenetic inference.

\section{Pathogenicity}

Representative isolates from each species complex were tested for their pathogenicity against banana variety Cavendish (Fig. 5). Selected isolates included InaCC F872, InaCC F950, and InaCC F992 (FFSC), InaCC F962 (FIESC), InaCC F974 and (FSSC). None of the isolates was able to cause any disease symptoms in the inoculated plants. All of the isolates tested caused only slight discoloration in the corm without any further disease development. 


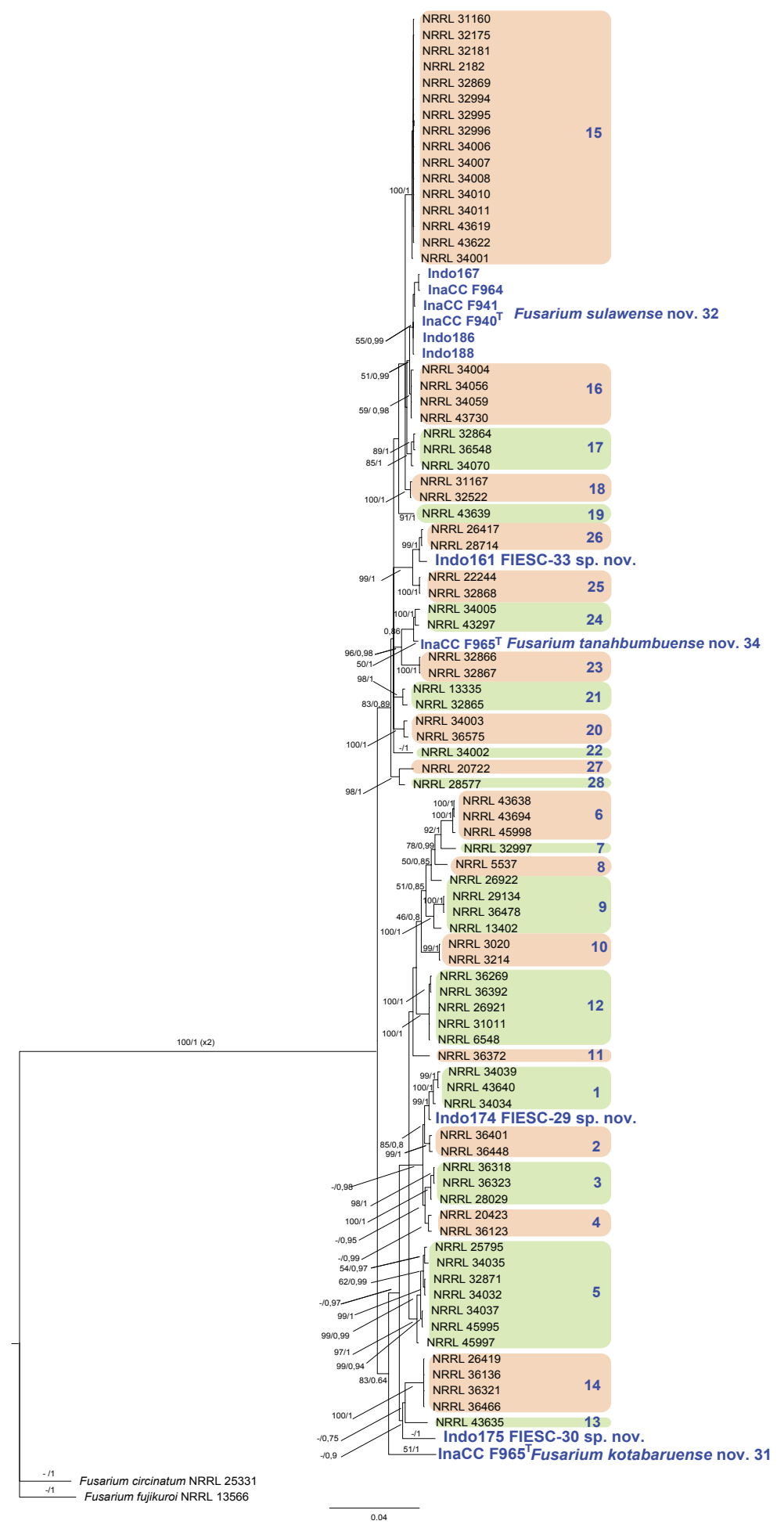

Fig. 3. Maximum likelihood tree inferred from the combined $c m d A$, ITS, $r p b 2$, tef1 and LSU sequence datasets of the Fusarium incarnatum-equiseti species complex (FIESC) including 11 Indonesian isolates (Indicated in blue).

Bootstrap support values and Bayesian posterior probabilities are given at each node. The tree is rooted to Fusarium circinatum (NRRL 25331) and Fusarium fujikuroi (NRRL 13566). 


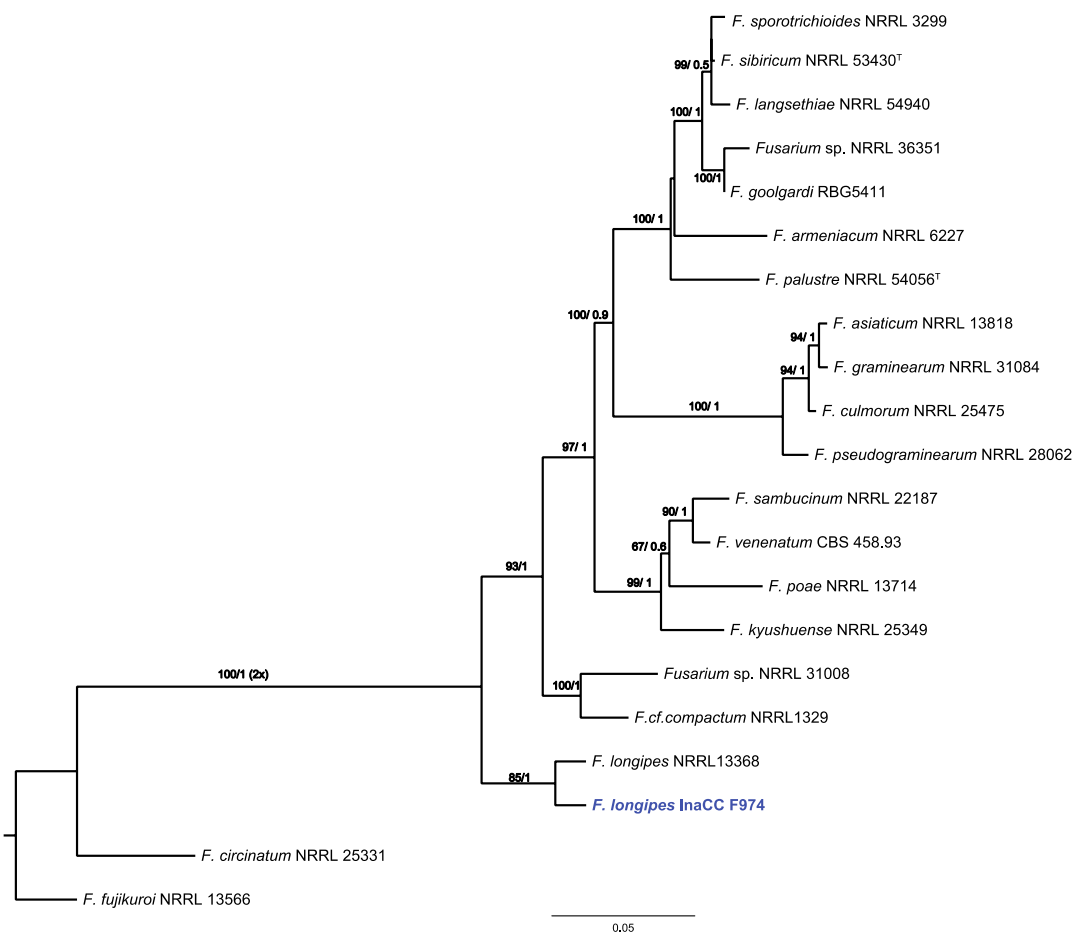

Fig. 4. Maximum likelihood tree inferred from the combined $r p b 1$ and $r p b 2$ sequence datasets of the Fusarium sambucinum species complex (FSSC) including one Indonesian isolate InaCC F974 (indicated in blue). Bootstrap support values and Bayesian posterior probabilities are given at each node. The tree is rooted to Fusarium circinatum (NRRL 25331) and Fusarium fujikuroi (NRRL 13566).

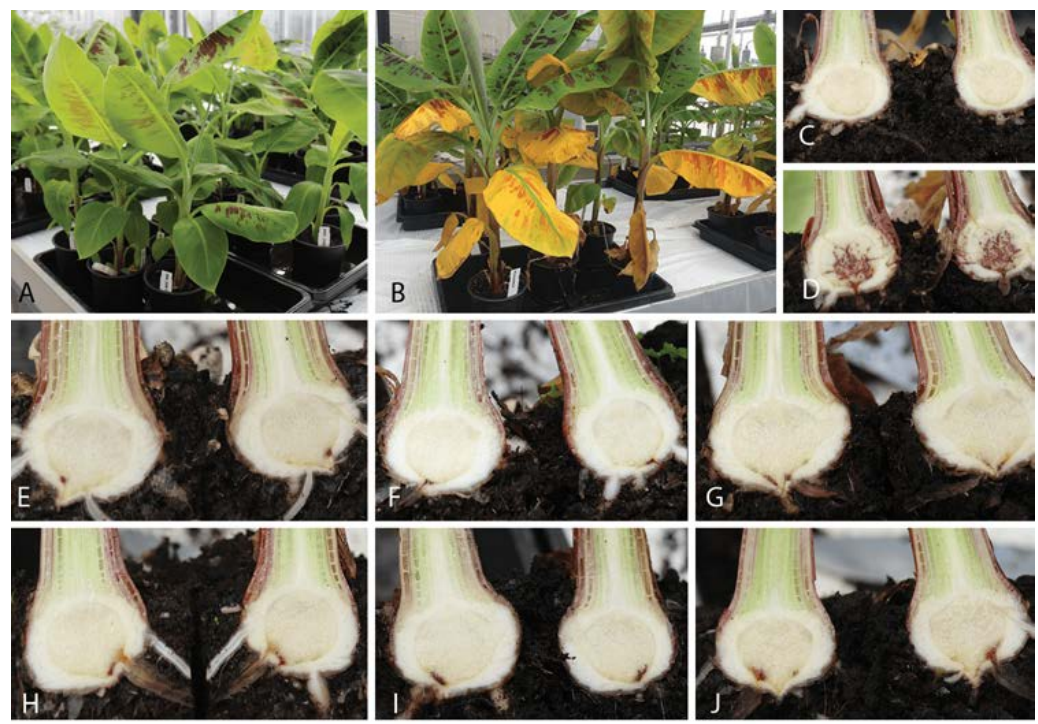

Fig. 5. Pathogenicity test of Fusarium spp. that belong to other species complexes. A. Plants before inoculation, B. Wilting symptom caused by Fusarium odoratissimum InaCC F856, seven weeks after inoculation, C. Control, D. Positive control Fusarium odoratissimum InaCC F856, E. Fusarium proliferatum (InaCC F992), F. Fusarium desaboruense (InaCC F950), G. Fusarium lumajangense (InaCC F872 ${ }^{\top}$ ), H. Fusarium longipes (InaCC F974), I. FIESC (Indo161), J. Fusarium lumajangense (InaCC F993). 


\section{Taxonomy}

The Fusarium species in each complex and novel species identified in this study are described below.

Fusarium lumajangense N. Maryani, M. Sandoval, L. Lombard, Kema \& Crous, sp. nov. MycoBank MBXXXXXXX. Fig.6

Etymology: Name refers to Lumajang, the region from where this species was collected in Indonesia.

Sporulation abundant from conidiophores carried on aerial mycelium and from sporodochia. Conidiophores on aerial mycelium, septate, branching profusely, irregularly or sympodially or reduced to solitary conidiogenous cells formed laterally on aerial hyphae; conidiogenous cells mono- or polyphialidic, acute, subulate or subcylindrical, smooth- and thin-walled (6-)10$22.5(-31.5) \times 2-3(-4) \mu \mathrm{m}$, formed terminally and singly on conidiophores or intercalary, often proliferating percurrently; periclinal thickening inconspicuous or absent; conidia of two types: a) (microconidia) ovoid to ellipsoid, smooth- and thin-walled, (6-)9-18(-23) $\times(2-) 3(-5) \mu \mathrm{m}$ (av. $13 \times 4 \mu \mathrm{m}$ ), 0-1-septate, arranged in false heads on monophialides; and b) (macroconidia) falcate and multiseptate, apical cells papillate, basal cells indistinct or foot-shaped, (1-2-)3septate, formed on polyphialides; 1-septate conidia $18.5 \times 3.5 \mu \mathrm{m}$; 2-septate conidia $40 \times 4$ $\mu \mathrm{m}$; 3-septate conidia (26-)29-39.5(-44.5) × (3-)3.5-4.5(-5.5) $\mu \mathrm{m}$; av. (18.5-)28-39.5(-44.5) $\times(3-) 3.5-4.5(-5.5) \mu \mathrm{m}$. Sporodochia formed abundantly on surface of carnation leaves after $7 \mathrm{~d}$, pale orange to orange. Conidiophores on sporodochia, septate, mostly unbranched or rarely sparsely and irregularly branched, bearing terminal monophialides, carried singly or grouped in verticillately branched; conidiogenous cells monophialidic, ampulliform, doliiform to subcylindrical, smooth- and thin-walled, (11.5-)12.5-18.5(-23.5) $\times(2-) 3-4(-4.5) \mu \mathrm{m}$, proliferating percurrently several times, with short collarets and inconspicuous periclinal thickening; sporodochial conidia falcate, apical cells gently curved, papillate, basal cells slightly curved, foot-shaped, 3-5 septate: 3-septate conidia, (30-)34.5-46.5(-54) × 3.5-4.5 $\mu \mathrm{m}$; 4septate conidia, 41-48(-52.5) × (3-)3.5-4.5 $\mu \mathrm{m}$; 5-septate conidia, (42.5-)45-53(-56) × 3.5$4.5 \mu \mathrm{m}$; av. (30-)40-50.5(-56) × (3-)3.5-4(-4.5) $\mu \mathrm{m}$. Chlamydospores not observed.

Culture characteristics: Colony on PDA showing optimal growth at $25{ }^{\circ} \mathrm{C}$ with an average growth rate of 3.5-4.6 $\mathrm{mm} / \mathrm{d}$. Colony reverse, liliac to violet becoming white towards the margin, later becoming dark purple with time. Colony surface dry, white becoming livid purple towards the margin, turning completely purple with age. Aerial mycelium abundant, cottony, with moderate sporulation and lacking exudates. 
Geography and host: Lumajang, East Java, Musa acuminata. var. Pisang Mas Kirana (AA).

Pathogenicity: Non-pathogenic on Cavendish (AAA).
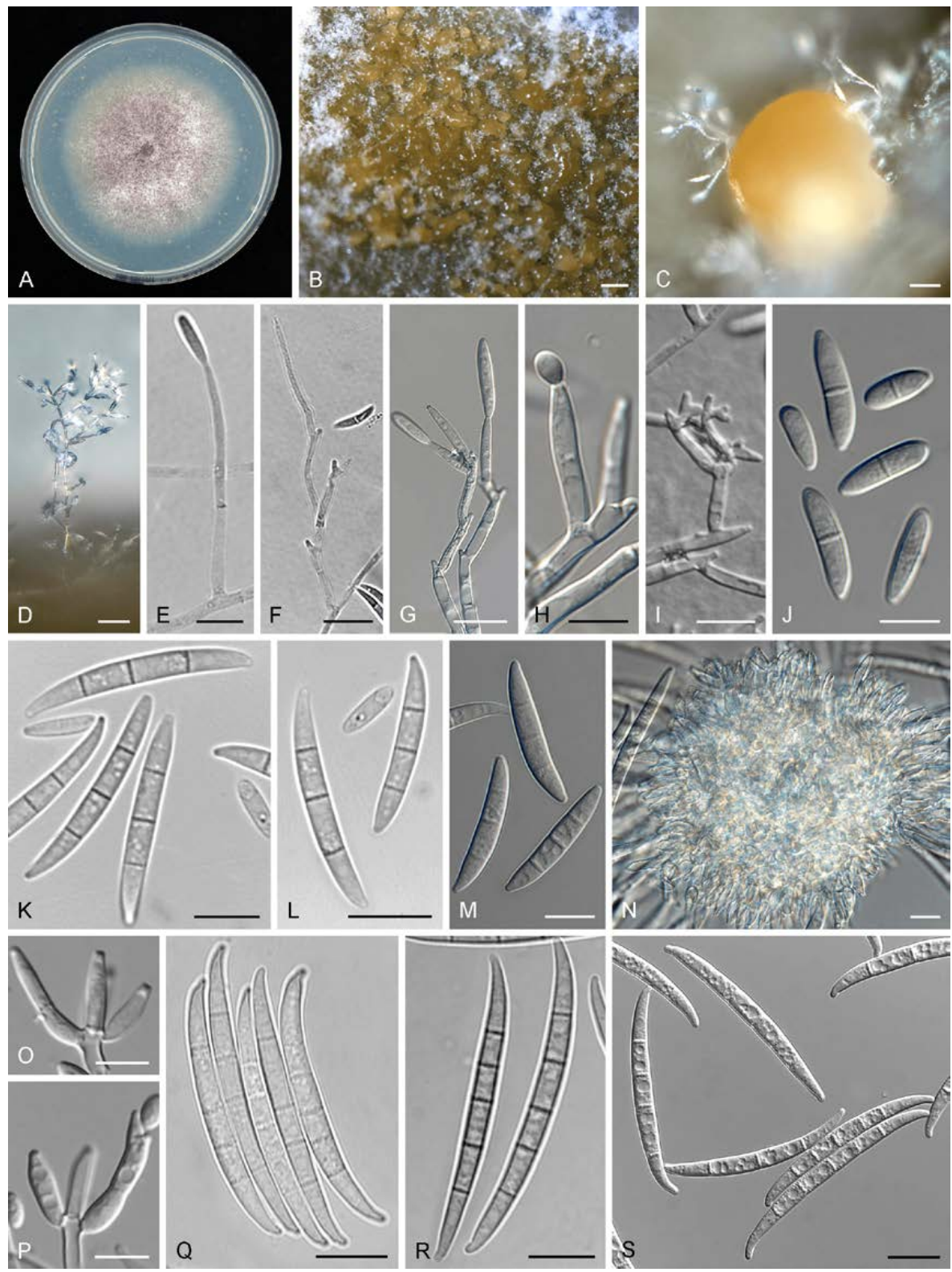

Fig. 6. Fusarium lumajangense (ex-type InaCC F993). A. Culture grown on PDA. B-C. Sporodochia on carnation leaves. D-I. Aerial conidiophores and phialides. J-M. Aerial conidia. N-P. Sporodochial conidiophores and phialides. Q-S. Sporodochial conidia. Scale bars: $B-D=50 \mu \mathrm{m}, E=5 \mu \mathrm{m}, \mathrm{F}-\mathrm{S}=10 \mu \mathrm{m}$. 
Material examined: Indonesia, Desa Kandang Kepus, Kecamatan Senduro, Lumajang, East Java $\left(113^{\circ} 4^{\prime} 157^{\prime \prime} \mathrm{E}\right.$, $8^{\circ} 4^{\prime} 46^{\prime \prime}$ S), in infected pseudostem of Musa acuminata var. Pisang Mas Kirana (AA), 17 Jul. 2014, N. Maryani (holotype InaCC F872, ex-type culture InaCC F993; Desa Kandang Kepus, Kecamatan Senduro, Lumajang, East Java (113 $\left.{ }^{\circ} 4^{\prime} 157^{\prime \prime} \mathrm{E}, 8^{\circ} 4^{\prime} 46^{\prime \prime} \mathrm{S}\right)$, in infected pseudostem of Musa acuminata var. Pisang Mas Kirana (AA), $17 \mathrm{Jul}$ 2014, N. Maryani (InaCC F993).

Notes: Fusarium lumajangense exhibits similar morphological features to F. mangiferae (Britz et al. 2002), also clustering in a sister relationship with the latter species. However, besides its clear phylogenetic delimitation, the polyphialides found in F. lumajangense commonly present two conidiogenous loci. Similar to F. subglutinans described by Nelson et al. (1983), except that the microconidia in F. lumajangense were formed both on mono- and polyphialides.

Fusarium desaboruense N. Maryani, M. Sandoval, L. Lombard, Kema \& Crous, sp. nov. MycoBank MBXXXXXXX. Fig. 7

Etymology: Name refers to Desa Boru, the village from where this species was collected in Indonesia.

Sporulation abundant from conidiophores carried on aerial mycelium and from sporodochia. Conidiophores on aerial mycelium abundant on PDA and SNA, less frequent on CLA, septate, sparingly or profusely branching irregularly or sympodially, rarely reduced to solitary conidiogenous cells, formed laterally on aerial hyphae; conidiogenous cells mono- or polyphialidic, acute, subulate or subcylindrical, smooth- and thin-walled (6-)15-33(-44) $\times(2-$ 2.5-4(-7) $\mu \mathrm{m}$ (av. $21.5 \times 3 \mu \mathrm{m}$ ), formed terminally, singly or in whorls on conidiophores or intercalary, proliferating percurrently, periclinal thickening inconspicuous or absent; conidia of two types: a) (microconidia) ovoid to ellipsoid, smooth- and thin-walled, (10-)11-16(-18) $\times(4-) 6(-7) \mu \mathrm{m}$ (av. $13 \times 5 \mu \mathrm{m}), 0-1$-septate, arranged in false heads on monophialides; and b) (macroconidia) falcate and multiseptate, apical cells papillate, basal cells indistinct or footshaped, 1-3-septate, formed on polyphialides: 1-septate conidia $22.5-26(-27) \times 3.4-4 \mu \mathrm{m}$; 2 septate conidia (21.5-)22-26 × 3-4.5 $\mu \mathrm{m}$; 3-septate conidia (23-)24.5-34(-37) × 3-4.5 $\mu \mathrm{m}$; av. (21.5-)22-30.5(-37) × 3-4.5 $\mu \mathrm{m}$. Sporodochia formed abundantly on CLA after $7 \mathrm{~d}$, pale orange to orange. Conidiophores in sporodochia unbranched, rarely laterally branched up to two times; conidiogenous cells monophialidic, smooth- and thin-walled (15.5-)16.5-24(-29) $\times(2.5-) 3-4 \mu \mathrm{m}$ (av. $20 \times 3.5 \mu \mathrm{m}$ ), solitary, terminal or lateral, or in terminal groups of up to three conidiogenous cells, with minute collarettes and periclinal thickening; sporodochial conidia falcate, apical cells gently curved, papillate, basal cells gently curved, foot-shaped, 13(-4)-septate. 1-septate conidia (14.5-)15-20.5(-22) × 3.5-4.5 $\mu \mathrm{m}$; 2-septate conidia (20.5-

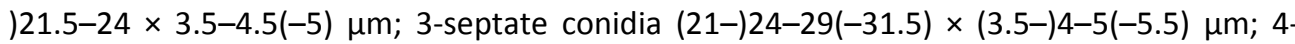


septate conidia $34 \times 5.5 \mu \mathrm{m}$; av. (14.5-)20-28(-34.5)×(3.5-)4-5(-5.5) $\mu \mathrm{m}$. Chlamydospores not observed.
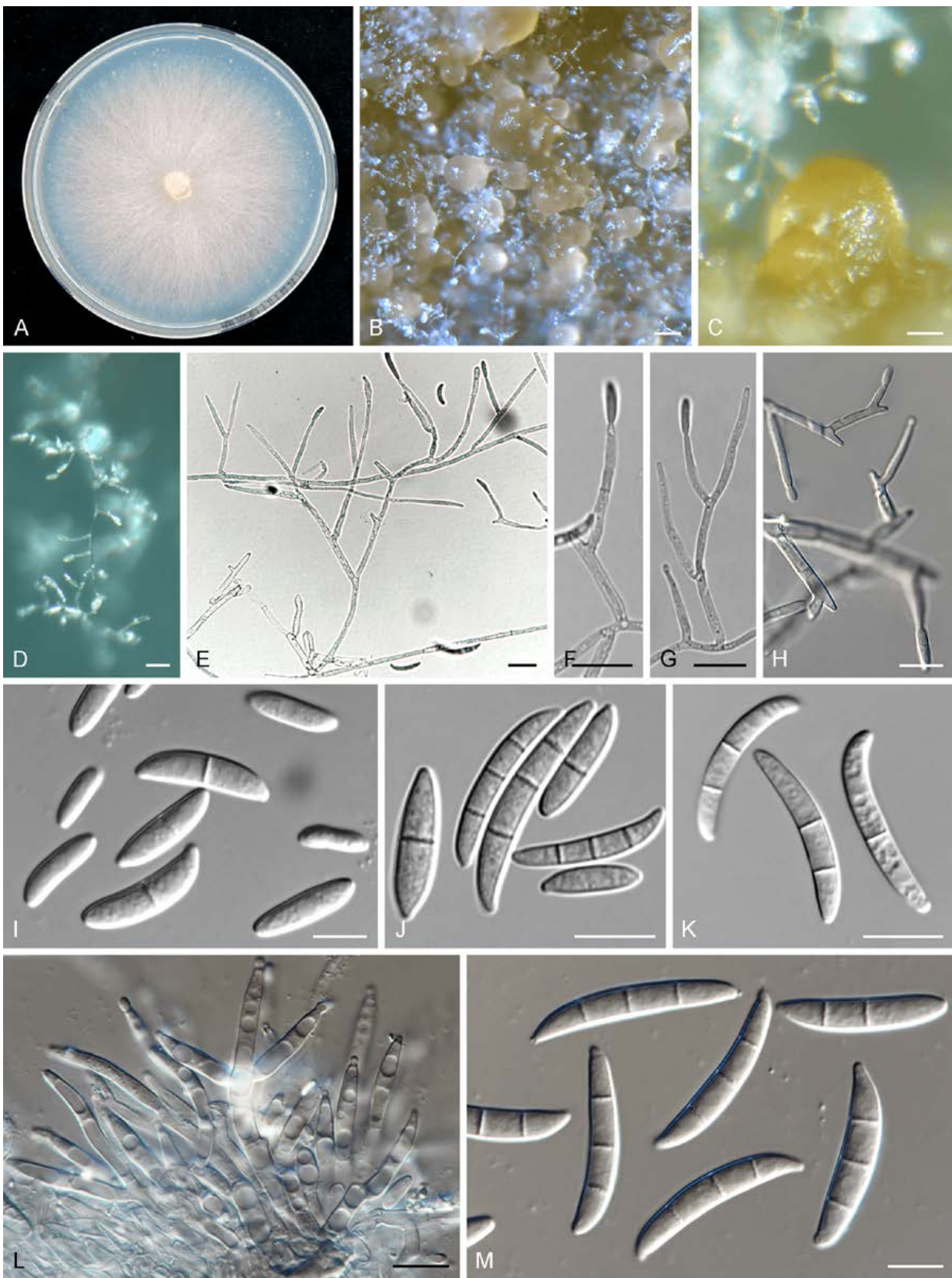

Fig. 7. Fusarium desaboruense (ex-type InaCC F950). A. Culture grown on PDA. B-C. Sporodochia on carnation leaves. D-H. Aerial conidiophores and conidiogenous cells. I-K. Aerial conidia. L. Sporodochial conidiophores and phialides. M. Sporodochial conidia. Scale bars: $\mathbf{B}-\mathbf{E}=20 \mu \mathrm{m}, \mathrm{D}-\mathbf{M}=10 \mu \mathrm{m}$. 
Culture characteristics: Colony on PDA showing optimal growth at $25{ }^{\circ} \mathrm{C}$ with an average growth rate of $4.9-5.2 \mathrm{~mm} / \mathrm{d}$. Colony reverse, pale violet becoming white towards the margins, turning violet with age and pigmented. Colony surface cottony, pale violet, becoming white with age, immersed mycelium becoming purple and lacking exudates. Aerial mycelium abundant, cottony, with abundant sporulation.

Geography and host: Sikka Flores, East Nusa Tenggara, Musa sp. var. Pisang Kepok (ABB).

Pathogenicity: Not pathogenic on Cavendish (AAA).

Material examined: Indonesia, Desa Boru, Kecamatan Waigate, Sikka Flores, East Nusa Tenggara $\left(122^{\circ} 22^{\prime} 7^{\prime \prime} \mathrm{E}\right.$ and $8^{\circ} 36^{\prime} 49^{\prime \prime}$ S), on infected pseudostem of Musa sp. var. Pisang Kepok (ABB), 17 Aug. 2015, N. Maryani (holotype InaCC F950, ex-type culture InaCC F950); Desa Boru, Kecamatan Waigate, Sikka Flores, East Nusa Tenggara $\left(122^{\circ} 22^{\prime} 7^{\prime \prime} \mathrm{E}\right.$ and $\left.8^{\circ} 36^{\prime} 49^{\prime \prime} \mathrm{S}\right)$, on infected pseudostem of Musa sp. var. Pisang Kepok (ABB), 17 Aug. 2015, N. Maryani (InaCC F 951, InaCC F 952).

Notes: Morphologically very similar to F. sacchari ((J. Gams) Leslie \& Summerell (2006)) and F. subglutinans (Nelson et al. 1983), except that this species produces sporodochia abundantly under regular culturing conditions. F. desaboruense can be distinguished by the septation of its macroconidia (1-4-septate) and microconidia (1-3-septate), not observed in F. saccari (Leslie \& Summerell 2006). Phylogenetic analyses of partial rpb2 gene sequences recognized this species as distinct from $F$. sacchari with strong support of BP $99 \%$.

Fusarium tanahbumbuense (FIESC-34) N. Maryani, M. Sandoval, L. Lombard, Kema \& Crous, sp. nov. MycoBank MBXXXXXXX. Fig.8

Etymology: Name refers to Tanah Bumbu, the region from where this species was collected in Indonesia.

Sporulation abundant from conidiophores borne on aerial mycelium and from sporodochia. Conidiophores on aerial mycelium abundant on PDA, SNA, and CLA, septate, irregularly of verticillately branched; conidiogenous cells monophialidic or polyphialidic, subulate or subcylindrical, smooth- and thin-walled, (11-)13-24(-38) ×(4-)5-6(-7) $\mu \mathrm{m}$ (av. $19 \times 6 \mu \mathrm{m}$ ), formed terminally, singly or in groups of up to three cells on a stipe, or carried singly and laterally on aerial mycelium, collarettes and periclinal thickening inconspicuous or absent; conidia of one type (macroconidia) falcate and multiseptate, apical cells conical to papillate, basal cells indistinct or foot-shaped, 3-5-septate, formed on both mono- and polyphialides, 3septate conidia, 31-36(-38.5) × 3.5-5(-5.5) $\mu \mathrm{m}$; 4-septate conidia, (31-)33.5-43.5(-48) × 3.5$5(-5.5) \mu \mathrm{m}$; 5-septate conidia, (30-)37-45(-47) × 4-5.5(-6) $\mu \mathrm{m}$; av. (30-)34.5-44(-48) × (3.5- 
14-5.5(-6) $\mu \mathrm{m}$. Sporodochia formed abundantly on CLA after $7 \mathrm{~d}$, pale orange; conidiophores in sporodochia irregularly and laterally branched; conidiogenous cells monophialidic, doliiform to ampulliform, smooth- and thin-walled, (9.5-)10-13(-15) × (2.5-)3-4 $\mathrm{mm}$ (av. $11.5 \times 3.5 \mu \mathrm{m})$, collarettes or periclinal thickening inconspicuous or absent; sporodochial conidia falcate, apical cells gently curved, papillate; basal cells slightly curved, foot-shaped; (2-)3-5-septate; 2-septate conidia, $40.5 \times 4.5 \mu \mathrm{m}$; 3-septate conidia, (25.5-)29-36.5(-41) × 3.5-4.5 $\mu \mathrm{m}$; 4septate conidia, (32.5-)34-40(-46) × 3.5-4.5(-5) $\mu \mathrm{m}$; 5-septate conidia, (36-)37-43.5(-49) ×

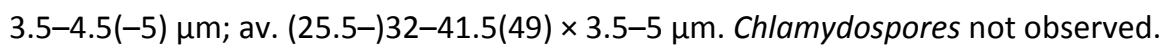

Culture characteristics: Colony on PDA showing optimal growth at $25{ }^{\circ} \mathrm{C}$ with an average growth rate of $1.3-2.2 \mathrm{~mm} / \mathrm{d}$. Colony reverse, rosy buff becoming white towards the margins, turning cinnamon to fawn with age and pigmented. Colony surface cottony, rosy buff becoming white towards the margin, turning hazel with age. Aerial mycelium abundant, cottony, with high sporulation and lacking exudates.

Geography and host: Tanah Bumbu, South Kalimantan, Musa sp. var. Pisang Hawa (ABB).

\section{Pathogenicity: NA.}

Material examined: Indonesia, Desa Betung, Kecamatan Kusan Hilir, Tanah Bumbu, Kalimantan Selatan $\left(115^{\circ} 37^{\prime} 477^{\prime \prime} \mathrm{E}, 3^{\circ} 50^{\prime} 77^{\prime \prime S}\right)$, on infected pseudostem of Musa sp. var. Pisang Hawa (ABB), 20 Jun. 2014, N. Maryani (holotype InaCC F965).

Notes: Fusarium tanahbumbuense can be distinguished from F. semitectum (Leslie \& Summerell 2006, Nelson et al. 1983) by the absence of microconidia and chlamydospores. The polyphialides observed for this species also greatly differed from those that have been observed for F. semitectum which have 3-5 openings (Nelson et al. 1983). 

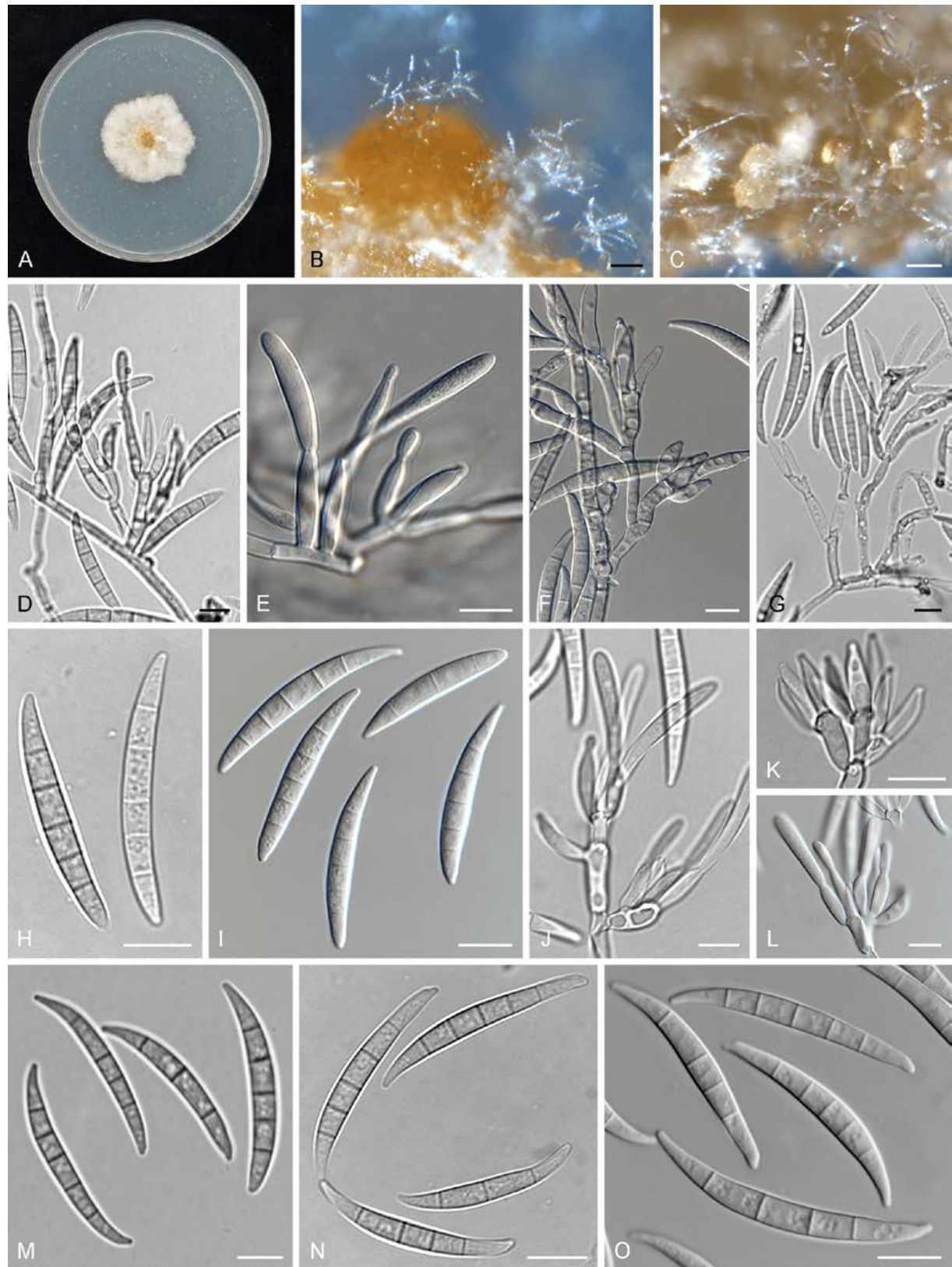

Fig. 8. Fusarium tanahbumbuense, FIESC-34 (ex-type InaCC F965). A. Culture grown on PDA. B-C. Sporodochia on carnation leaves. D-G. Aerial conidiophores and conidiogenous cells. H-I. Aerial conidia. J-L. Sporodochial conidiophores and conidiogenous cells. $\mathbf{M}-\mathbf{O}$. Sporodochial conidia. Scale bars: B-C=50 $\mu \mathrm{m}, \mathrm{D}-\mathrm{O}=10 \mu \mathrm{m}$. 
Fusarium sulawense (FIESC-32) N. Maryani, M. Sandoval, L. Lombard, Kema \& Crous, sp. nov. MycoBank MBXXXXXXX. Fig.9

Etymology: Name refers to Sulawesi, the island from where this species was collected in Indonesia.

Sporulation abundant from conidiophores carried on aerial mycelium and from sporodochia. Conidiophores on aerial mycelium abundant on PDA and SNA, less frequent on CLA, septate, irregularly or verticillately branched; conidiogenous cells mono- or polyphialidic, subulate to subcylindrical, smooth- and thin-walled, (8.5-)14-22.5(-27) $\times(2-) 2.5-4(-4.5) \mu \mathrm{m}$ (av. $18 \times 3$ $\mu \mathrm{m})$, formed singly, laterally or terminally, or more often in groups of 2-3 cells, sometimes proliferating percurrently, collarettes and periclinal thickening inconspicuous or absent; conidia of one type (macroconidia), falcate and multiseptate, apical cells papillate, basal cells indistinct or foot-shaped, 3-5(-9)-septate, formed on both mono- and polyphialides, 3septate conidia, 20.5-47.5(-55) × 3.5-5 $\mu \mathrm{m}$; 5-septate conidia, (33.5-)39.5-48(-50.5) × (4) 4.5-5.5 $\mu \mathrm{m}$; 6-septate conidia $51.5 \times 6 \mu \mathrm{m}$; 9-septate conidia, $67 \times 5.5 \mu \mathrm{m}$; av. (20.5-)36-51($67.5) \times(3.5-) 4-5.5(-6) \mu \mathrm{m}$.

Sporodochia formed rarely on CLA after $7 \mathrm{~d}$, pale orange; conidiophores in sporodochia unbranched or irregularly branched, densely packed, bearing terminal clusters of 2-5 conidiogenous cells; conidiogenous cells monophialidic, short ampulliform, smooth- and thinwalled, (8.5-)9-11.5(-13) × (3-)3.5-5(-5.5) $\mu \mathrm{m}$ (av. $10.5 \times 4.5 \mu \mathrm{m}$ ) with a minute collarette and inconspicuous periclinal thickening; sporodochial conidia falcate, apical cells gently curved, papillate; basal cells slightly curved, foot-shaped, (3-)5(-6)-septate; 3-septate conidia, (29.5-)30-44 × 4-4.5 $\mu \mathrm{m}$; 4-septate conidia, $30 \times 5.5 \mu \mathrm{m}$; 5-septate conidia, (30-)36-41.5($43.5) \times(3.5-) 4-5(-5.5) \mu \mathrm{m}$; 6-septate conidia $43.5 \times 5 \mu \mathrm{m}$; av. (30-)36-41.5(-44) $\times(3.5-) 4-$ 5(-5.5) $\mu \mathrm{m}$. Chlamydospores not observed.

Culture characteristics: Colony on PDA showing optimal growth at $25{ }^{\circ} \mathrm{C}$ with an average growth rate of 5.2-6.0 mm/d. Colony reverse rosy buff becoming white towards the margins. Colony surface dry, cottony, saffron. Aerial mycelium abundant, cottony, with high sporulation and lacking exudates.

Geography and host: Bone, South Sulawesi, Musa acuminata var. Pisang Cere (AAA).

Pathogenicity: Non-pathogenic on Cavendish (AAA). 
Material examined: Indonesia, Desa Seli, Kecamatan Bengo, Bone, Sulawesi Selatan (120 $\left.0^{\circ} 12.8^{\prime \prime} \mathrm{E}, 4^{\circ} 37^{\prime} 26^{\prime \prime} \mathrm{S}\right)$, on infected pseudostem of Musa acuminata var. Pisang Cere (AAA), 12 Aug. 2015, N. Maryani (holotype InaCC F940), ex-type culture InaCC F940); Desa Sungai Birah, kecamatan Pamukan Barat, Kota Baru, Kalimantan Selatan $\left(115^{\circ} 59^{\prime} 982^{\prime \prime} \mathrm{E}, 2^{\circ} 22^{\prime} 883^{\prime \prime} \mathrm{S}\right)$, on infected pseudostem of Musa sp. var. Pisang Hawa (ABB), 19 Jun. 2014, N. Maryani (InaCC F964).
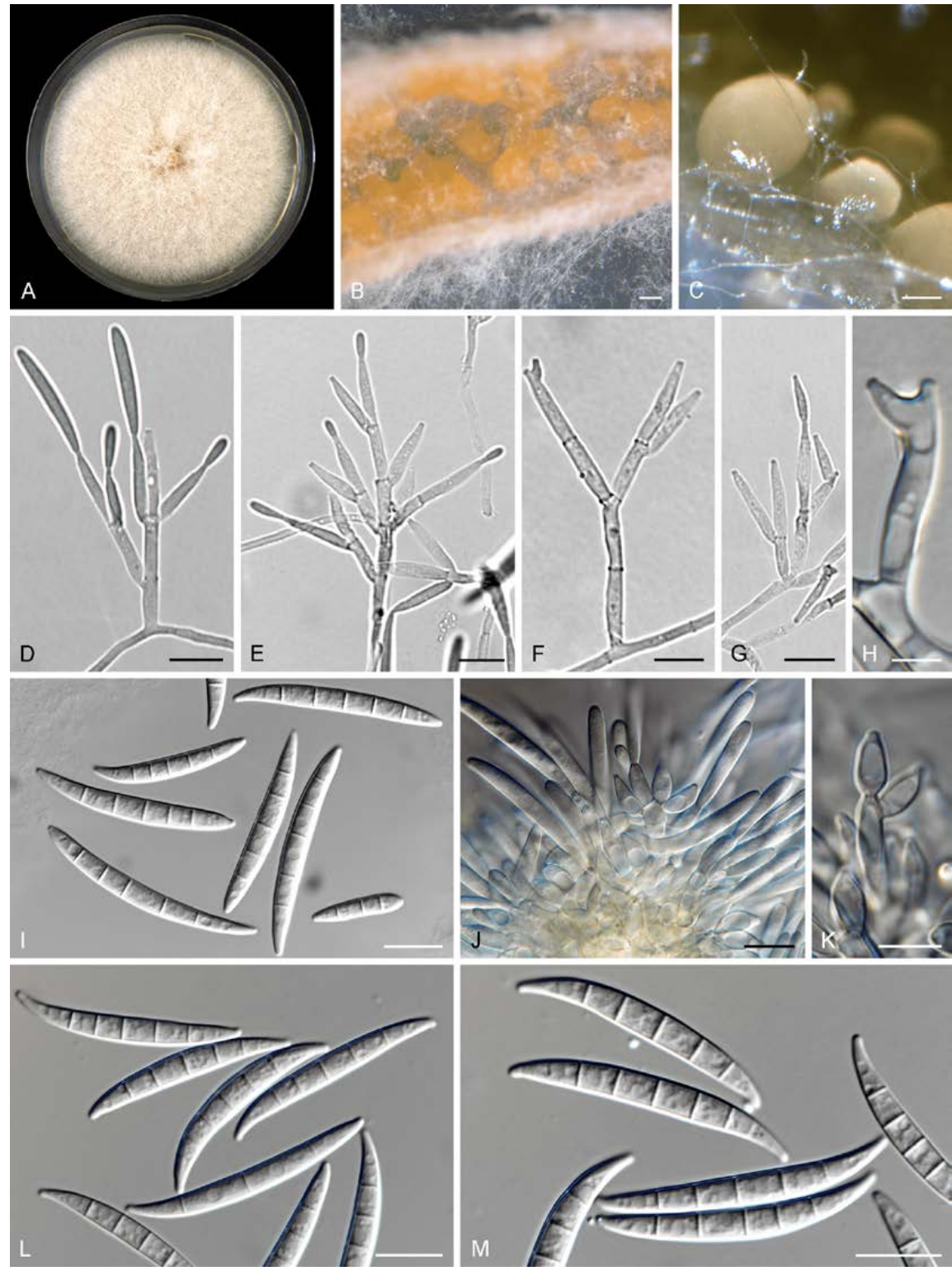

Fig. 9. Fusarium sulawense FIESC-32 (ex-type InaCC F964). A. Culture grown on PDA. B-C. Sporodochia on carnation leaves. D-H. Aerial conidiophores and conidiogenous cells. I. Aerial conidia. J-K. Sporodochial conidiophores and conidiogenous cells. L-M. Sporodochial conidia. Scale bars: B-C=50 $\mu \mathrm{m}, \mathrm{H}=5 \mu \mathrm{m}, \mathrm{D}-\mathrm{G}, \mathrm{I}-\mathrm{M}=$ $10 \mu \mathrm{m}$. 
Notes: Fusarium sulawense is relatively fast growing (av. 5.2-6.0 mm/d) compared to its sister species in the Incarnatum clade F. FIESC-34 (av. 1.3-2.2 mm/d). Members of this species were recovered from different banana varieties in the Kalimantan and Sulawesi islands of Indonesia.

Fusarium kotabaruense (FIESC-31) N. Maryani, M. Sandoval, L. Lombard, Kema \& Crous, sp. nov. MycoBank MBXXXXXXX. Fig.10

Etymology: Name refers to Kota Baru one of the nine regencies in the Indonesian province of South Kalimantan.

Sporulation abundant from conidiophores carried on aerial mycelium. Conidiophores on aerial mycelium abundant on PDA and SNA, less frequent on CLA, septate, irregularly branching; conidiogenous cells mono- or polyphialidic, subulate to subcylindrical, smooth- and thinwalled, (15-)19-33(-40) ×4-7 $\mu \mathrm{m}$ (av. $26 \times 5 \mu \mathrm{m}$ ), forming terminally, singly or in verticillately branched conidiophores, less commonly laterally or intercalary, proliferating percurrently, periclinal thickening inconspicuous or absent; falcate and multiseptate, apical cells papillate, basal cells indistinct or foot-shaped, (2-)3-5(-7)-septate, formed on both mono- and polyphialides, 2-septate conidia, (21-)21.5-25(-26) × 5-6 $\mu \mathrm{m}$; 3-septate conidia, (24.5-)28$35(-36.5) \times 5.5-6.5(-7) \mu \mathrm{m}$; 4-septate conidia, (32-)34-39.5(-41.5) × 5.5-6.5(-7) $\mu \mathrm{m}$; 5septate conidia, (34.5-)36-42.5(-45) × (5-)5.5-6.5(-7.5) $\mu \mathrm{m} ; 6$-septate conidia, 39-40.5 × 5.5-7 $\mu \mathrm{m}$; 7-septate conidia, (38.5-)39.5-44(-45) × 6-7 $\mu \mathrm{m}$; av. (21-)31.5-41.5(-45) × (5)5.5-6.5(-7.5) $\mu \mathrm{m}$. Sporodochia and chlamydospores not observed.

Culture characteristics: Colony on PDA showing optimal growth at $25{ }^{\circ} \mathrm{C}$ with an average growth rate of 5.0-6.85 mm/d. Colony reverse rosy buff. Colony surface cottony rosy buff. Aerial mycelium abundant, cottony, with high sporulation and lacking exudates.

Geography and host: Kota Baru, South Kalimantan, Musa sp. var. Pisang Hawa (ABB).

Pathogenicity: Non-pathogenic on Cavendish (AAA).

Material examined: Indonesia, Desa Sungai Birah, Kecamatan Pamukan Barat, Kota Baru, Kalimantan Selatan $\left(115^{\circ} 59^{\prime} 982^{\prime \prime} \mathrm{E}, 2^{\circ} 22^{\prime} 883^{\prime \prime S}\right)$, on infected pseudostem of Musa sp. var. Pisang Hawa (ABB), 19 Jun. $2014, \mathrm{~N}$. Maryani (holotype InaCC F963).

Notes: Fusarium kotabaruense represents a species in the Equiseti clade of the FIESC and relatively fast growing $(5.0-6.85 \mathrm{~mm} / \mathrm{d})$. Most distinguishing characteristic of this species is 
the absence of sporodochia on CLA culture. However, aerial conidiophores are abundant with conidia produced with high variability on its septation, (0-)3-5(-7)-septate.
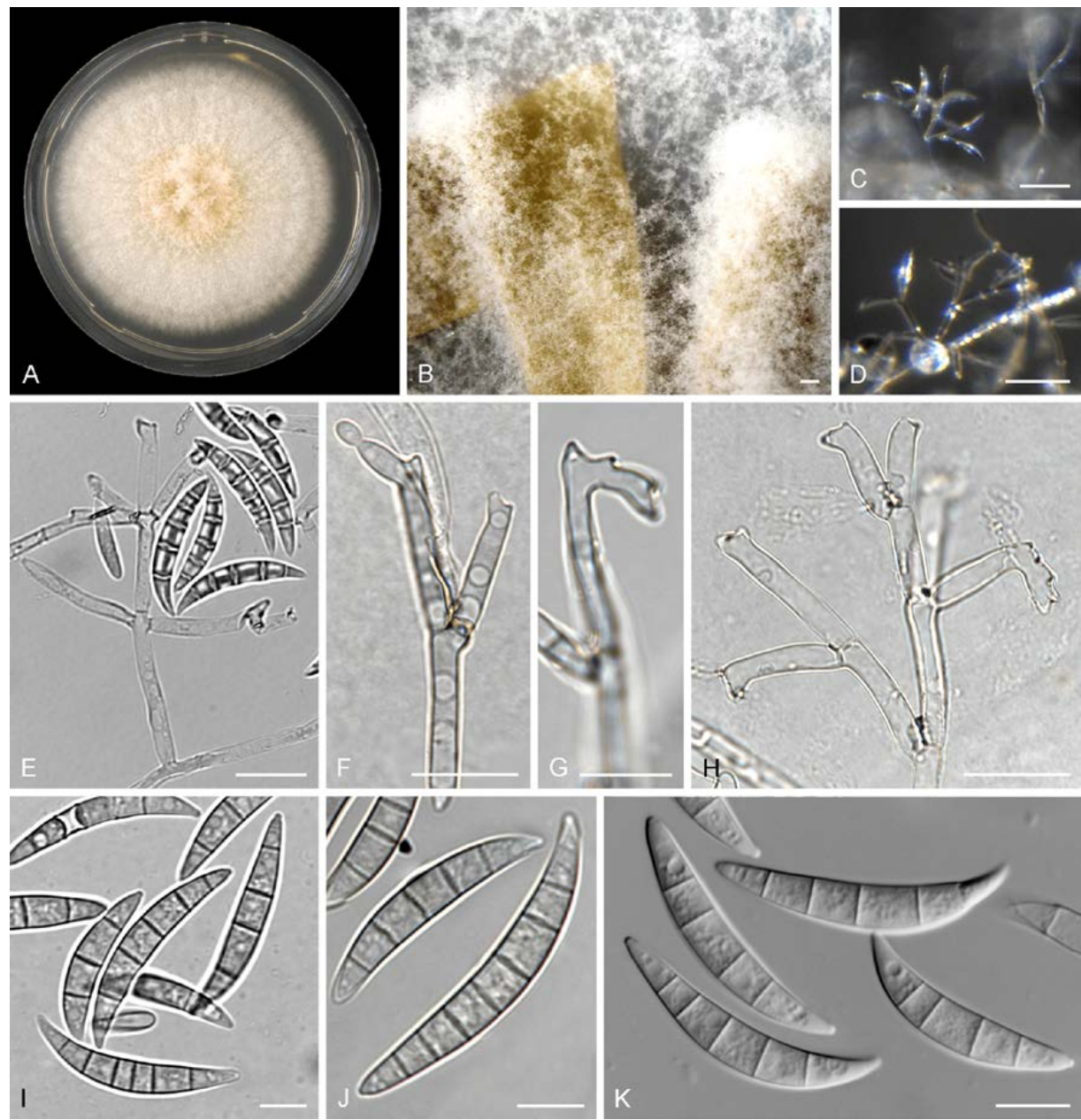

Fig. 10. Fusarium kotabaruense, FIESC-31 (ex-type InaCC F963). A. Culture grown on PDA. B. Mycelium on carnation leaves. C-H. Conidiophores and conidiogenous cells. I-K. Conidia. Scale bars: B=200 $\mu \mathrm{m}, \mathrm{C}-\mathrm{D}=50 \mu \mathrm{m}$, $\mathrm{G}=5 \mu \mathrm{m}, \mathrm{E}-\mathrm{F}, \mathrm{H}-\mathrm{K}=10 \mu \mathrm{m}$.

\section{Fusarium longipes InaCC F974 Fig.11}

Sporulation abundant from conidiophores carried on aerial mycelium and from sporodochia. Conidiophores on aerial mycelium abundant on PDA and SNA, rare on CLA, septate, branching irregularly, mostly reduced to solitary conidiogenous cells formed singly and laterally on aerial hyphae; conidiogenous cells monophialidic, doliiform to ampulliform, smooth- and thinwalled, $(7-) 10-13(-15) \times 3-4(-5) \mu \mathrm{m}$ (av. $12 \times 6 \mu \mathrm{m}$ ), formed laterally on aerial hyphae or clustering terminally on conidiophores, with a minute collarette; conidia (microconidia) 
obovoid to ellipsoid, rough- and thin-walled, (7-)10-19(-23) $\times(3-) 4(-5) \mu \mathrm{m}$ (av. $15 \times 4 \mu \mathrm{m}$ ), 0 -2-septate, arranged in false heads on monophialides. Sporodochia formed abundantly on CLA after $7 \mathrm{~d}$, bright orange, later turning red to purple; conidiophores in sporodochia highly irregularly or verticillately branched, sympodially to solitary conidiogenous cells; conidiogenous cells monophialidic, doliiform, ampulliform to subcylindrical, 7-11(-14) $\times(2-$ 2.5-3.5(-4) $\mu \mathrm{m}$ (av. $9.5 \times 3 \mu \mathrm{m}$ ), with inconspicuous collarets; sporodochial conidia falcate, apical cell strongly curved, tapering and whip-like with rounded apex, basal cell foot-shaped and elongated, (3-)4-5-septate: 3-septate conidia, $28.5 \times 3.5 \mu \mathrm{m}$; 4-septate conidia, (37)-38$43(-43.5) \times 4.5-5.5 \mu \mathrm{m}$; 5-septate conidia, (37-)42-49.5(-53.5) × (3.5-)4.5-5(-6) $\mu \mathrm{m}$; av. (28.5-)40.5-49.5(-53.5) ×(3-)4-5(-6) $\mu \mathrm{m}$. Chlamydospores ellipsoid, sub-globose to globose, formed intercalary or terminal, single or in pairs, or in clumps, (7-)10-13(-15) $\times(7-) 9-13(-$ 14) $\mu \mathrm{m}$ (av. $12 \times 11 \mu \mathrm{m})$, brown, rough-walled.

Culture characteristics: Colony on PDA showing optimal growth at $25{ }^{\circ} \mathrm{C}$ with an average growth rate of $4.2-4.9 \mathrm{~mm} / \mathrm{d}$. Colony reverse livid red becoming white towards the margin, becoming completely livid red to bay with age. Colony surface cottony greyish rose becoming vinaceous with age and white toward the margins. Aerial mycelium abundant, cottony, with high sporulation and lacking exudates. Sporodochia formed abundantly on CLA after $7 \mathrm{~d}$, pale orange to orange.

Geography and host: Katingan, Central Kalimantan, Musa sp. var. Pisang Awak (ABB).

Pathogenicity: Non-pathogenic on Cavendish (AAA).

Material examined: Indonesia, Desa Tewang Menyangen, T. Sangalang, Katingan, Central Kalimantan $\left(113^{\circ} 6^{\prime} 552^{\prime \prime} \mathrm{E}, 1^{\circ} 41^{\prime} 83^{\prime \prime} \mathrm{S}\right)$, on infected pseudostem of Musa sp. var. Pisang Awak (ABB), 23 Jun. 2014, N. Maryani (holotype InaCC F974).

Notes: This banana isolate of $F$. longipes displays some unique characteristics which differ slightly from F. longipes vide Leslie \& Summerell (2008), which include the presence of microconidia and chlamydospores. This species is more similar to $F$. equiseti as described by Nelson et al. (1983), except for the length of the long curvature of the macroconidia. Additionally, the chlamydospore formation also differs from the original description of $F$. longipes. 

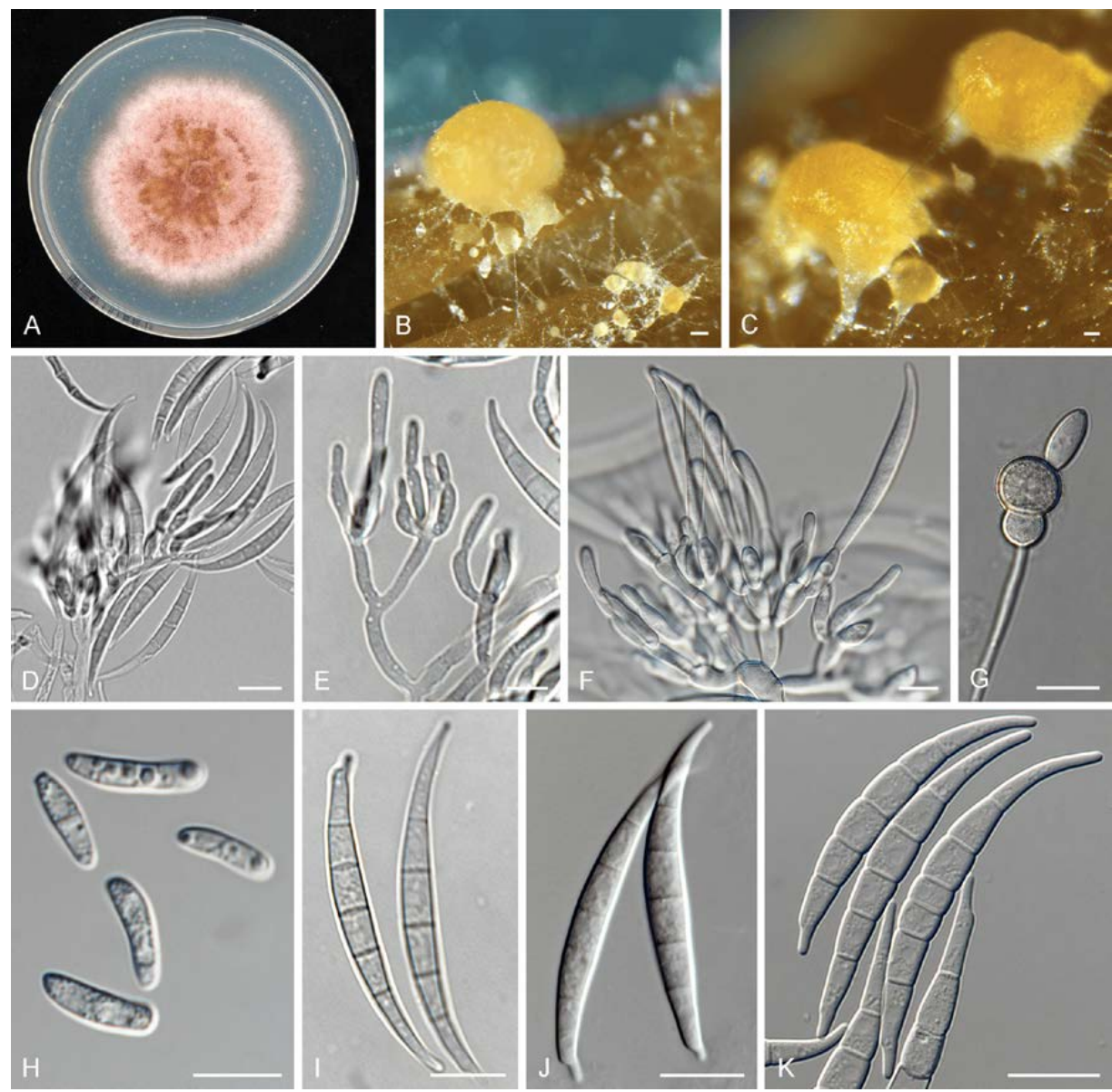

Fig. 11. Fusarium longipes (InaCC F974). A. Culture grown on PDA. B-C. Sporodochia on carnation leaves. D. Sporodochial conidiophores. E-F. Branched conidiophores. G. Falcate-shaped macroconidia. H. Microconidia I. Chlamydospores. Scale bars B-K=10 $\mu \mathrm{m}$.

\section{DISCUSSION}

This study further expands our knowledge on the diversity of Fusarium species isolated from banana plants displaying symptoms of Fusarium wilt in Indonesia, the centre of origin for this economically important crop. It is not surprising that $90 \%$ of the isolates recovered from the samples were members of FOSC, as the diseased pseudostem of banana served as source of isolation (Maryani et al. 2019). However, the remaining isolates were tentatively identified as members of other Fusarium species complexes, which included the FIESC, FSSC and FFSC. Remarkably, only Fusarium species were isolated, while no other fungal genera could be recovered from the banana samples. This indicates a marked dominance of Fusarium in diseased banana plants. It is well known that Fusarium is commonly associated with higher plants, being ubiquitous in terrestrial ecosystems, especially in the tropics, where most diseases on perennial crops are induced by this genus (Ploetz 2006). It has also been suggested 
that for any Fusarium associated disease found in plants, many other Fusarium species also reside in the same host as endophytes (Leslie \& Summerell 2006). Moreover, the samples were collected from locations in Indonesia where bananas are grown in mixed backyard ecosystems with other tropical crops (Maryani et al. 2019). This ecological niche enhanced the chance that a much higher diversity of Fusarium species would be discovered than expected.

We were able to identify a total 20 isolates collected from pseudostems of banana plants displaying symptoms of Fusarium wilt that did not belong to FOSC. These isolates were found to belong to three different Fusarium species complexes of which eight represented novel phylogenetic species in the FFSC and FIESC. Information regarding Fusarium spp. other than $F$. oxysporum in banana is scarce, since the majority of studies point to the specific detection and control of pathogenic strain of F. oxysporum (Ploetz et al. 2015, O'Donnell et al. 1998, Ordonez et al. 2015, Maryani et al. 2019). However, some studies have reported an abundance of Fusarium species in asymptomatic banana plant organs. Zakaria et al. (2011) identified Fusarium oxysporum, F. semitectum and F. solani (current name Neocosmospora solani) in healthy roots of wild banana plants (Musa acuminata) in Malaysia and Fusarium concentricum was reported in Musa sapientum from Costa Rica (Nirenberg \& O'Donnell 1998). Moreover, a higher diversity of Fusarium species have been reported from banana fruits, which included F. chlamydosporum, F. equiseti, F. proliferatum, F. sacchari, F. subglutinans and F. verticilloides (Zheng et al. 2014, Moretti et al. 2004, Jimenez et al. 1996). Two of these species, F. proliferatum and F. verticilloides, were also found in this study.

Pathogenicity tests demonstrated that the Indonesian isolates were not pathogenic on the Cavendish banana variety Grand Naine. Moreover, our results indicate that these species more likely play an endophytic role, which is consistent with previous knowledge on asymptomatic/ healthy banana plants (Zakaria \& Rahman 2011). A similar case has been reported on vanilla stem rot disease in Indonesia. Pinaria et al. (2010) isolated 12 Fusarium species from symptomatic vanilla stems. Pathogenicity tests indicated that none of these caused any disease on vanilla plants, with the exception of Fusarium oxysporum f. sp. vanillae. In another study, Fusarium oxysporum f. sp. vasinfectum was found to be the only species that caused Fusarium wilt of cotton amongst 20 Fusarium species isolated from wild Gossypium in Australia (Wang et al. 2004).

The highest diversity of isolates obtained in this study belonged to the FIESC. This species complex displays a remarkable abundance of phylogenetic species diversity which include both animal and plant associated pathogens, plant endophytes and soil inhabitants ( Leslie \& Summerell 2006, O'Donnell et al. 2009, Villani et al. 2016). Many of the FIESC have been isolated from various plants displaying disease symptoms, but their pathogenicity was never established (Leslie \& Summerell 2006). Previous studies have reported the presence of FIESC in banana fruits and roots, as well as causing storage rot of bananas (Leslie \& Summerell 2006, Zakaria et al. 2011, Zheng et al. 2012). However, this study represents the first report of 
FIESC from the pseudostem of bananas, indicating that members of this species complex have been isolated from every part of the banana plant. Thus far, species of the FIESC have been found to be more abundant in banana fruit, indicating a hemibiotrophic fungal lifestyle in plants (Bacon \& Yates 2006), and therefore these are often found in stored banana fruits, which are a very suitable environment for toxin producing fungal species like most FIESC members (Desjardins 2006).

The second most diverse Fusarium species complex found in this study was the FFSC. Five species where identified from banana, including the common plant pathogenic species $F$. proliferatum and $F$. verticilloides. Additionally, two novel species, $F$. lumajangense and $F$. desaboruense, were also identified in this study. The FFSC is known to include species able to cause disease in a variety of important agronomic crops, especially in the tropics (O'Donnell et al. 1998b). Each of the novel species identified in this complex were closely related to recognized plant pathogens: F. lumajangense is phylogenetically and morphologically closely related to F. mangiferae, a species causing mango-malformation on mango (Mangifera indica), and $F$. desaboruense is closely related to $F$. sacchari, the causal agent of "pokkah boeng" disease on sugar cane (Handojo et al. 1989, Britz et al. 2000). The plant pathogenic species $F$. proliferatum, a well-known pathogen on maize, sorgum, mango and asparagus, and F. verticilloides, a pathogen on maize (Handojo et al. 1989, Britz et al. 2002, Ploetz 2006b) and notorious producer of fumonisins (Desjardin 2006), were isolated at low frequency. Interestingly, all the hosts mentioned above are present in Indonesia as important cultivated crops. Moreover, Indonesian bananas are mainly produced in small scale household plantations and co-cultivated with other crops such as rice, maize, sugarcane, and other perennial tropical crops (Maryani et al. 2019). This complex agroecosystem from which our banana samples were obtained might explain the presence of FFSC species in banana plants affected by Fusarium wilt.

Members of the FFSC isolated in this study were not pathogenic to the banana variety Cavendish, which is similar to what has been stated for other crops. Fusarium fujikuroi, $F$. sacchari, $F$. subglutinans and $F$. verticilloides have been reported from rice affected by "Bakanae" disease, although, only F. fujikuroi, is known to cause the disease (Zainudin et al. 2008, Amatulli et al. 2010). A similar set of species in FFSC was also found in sugarcane, maize, and vanilla (Ploetz 2006b, Pinaria et al. 2010), thus suggesting that members of FFSC are associated with these crops without inducing disease. Moreover, their presence suggests an endophytic life style, causing no harm to the host plants or perhaps acting as secondary invaders or saprobes as the isolates were obtained from diseased plants. However, banana plants might serve as an intermediate host, as suggested by Handojo et al. (1989) for "Pokkah boeng" disease on sugar cane.

A single isolate was found to belong to the FSSC, identified as F. longipes based on phylogenetic inference, a species abundant in tropical areas as a soil inhabitant or as a 
saprophyte (Blackhouse \& Burgess 1995, Onyike \& Nelson 1993). However, to our knowledge, our finding is the first report of this species from banana since the report of Reinking \& Wollenweber (1927). They described F. longipes from mature living leaves of Musa sapientum in Honduras. Here, however, this species was cultured from the diseased pseudostem of banana variety Pisang Awak (ABB) on Kalimantan. This species appears to be commonly recovered from both healthy and diseased plants, suggesting that $F$. longipes could be endophytic in banana. This hypothesis was also further supported by the pathogenicity test conducted in this study. Fusarium longipes is known to be isolated more frequent during a higher rainfall period and under high temperatures (Burgess et al. 1988, Backhouse \& Burgess 1995). This is consistent with our findings where $F$. longipes was recovered from banana plants growing at a relatively high temperature $\left(35^{\circ} \mathrm{C}\right)$ and humidity $(62 \%)$. With morphological distinctions from the previous description of $F$. longipes, InaCC F974 found in this study might represent a novel species. More isolates and additional gene regions are needed to capture the possible diversity in morphology and phylogenetic relationships.

Our current study highlights the diversity of Fusarium species in banana plants exhibiting Fusarium wilt. While only Fusarium spp. in the FOSC has been shown to be a true pathogen (Stover 1962, Maryani et al. 2019), the role of the remaining species in banana plants requires further investigation. Whether these Fusarium species are true endophytes of the various varieties of banana sampled in this study, possible saprophytes or secondary pathogens should still be determined experimentally. Isolation from asymptomatic plants of similar banana varieties would provide possible evidence of an endophytic lifestyle of theFusarium species reported here. Moreover, the pathogenicity of each species on their respective host varieties needs to be tested in the future. Such studies would also reveal whether banana plants serve as intermediate hosts for a particular Fusarium species. Lastly, there is no doubt that tropical areas including Indonesia should receive more attention when studying Fusarium biodiversity.

\section{ACKNOWLEDGEMENTS}

This research was supported by the KNAW-SPIN Project, "The Indonesian banana: Protecting a staple food from Panama disease collapse and exploiting its genetic diversity for discovery research". NM was also supported by a DIKTI (Directorate General of Higher Education) Scholarship, Ministry of Research, Technology and Higher Education, Indonesia. Banana research at Wageningen University and Reseach is financially supported by the Dutch Dioraphte Foundation. Rahan Meristem, Israel, is gratefully acknowledged for supporting our trials by providing unlimited numbers of Cavendish banana plants.

\section{REFERENCES}

Aoki T, O'Donnell K, Geiser DM (2014). Systematics of key phytopathogenic Fusarium species: current status and future challenges. Journal of General Plant Pathology 80(3): 189-201.

Amatulli MT, Sparado D, Gullino ML, et al. (2010). Molecular identification of Fusarium spp. associated with bakanae disease of rice in Italy and assessment of their pathogenicity. Plant Pathology 59(5): 839-844.

Backhouse D, Burgess LW (1995). Mycogeography of Fusarium: climatic analysis of the distribution within Australia of Fusarium species in section Gibbosum. Mycological Research 99(10): 1218-1224. 
Bacon CW, Yates IE (2006). Endophytic root colonization by Fusarium species: Histology, plant interactiin, and toxicity. In : Microbial root endophytes (Schulz B, Boyle C, Sieber T, eds) Springer, Germany : 133-152.

Booth C (1971). The Genus Fusarium. CAB, Commonwealth Mycological Institute, England.

Britz H, Steenkamps ET, Coutinho TA, et al. (2002). Two new species of Fusarium section Liseola associated with mango malformation. Mycologia 94(4): 722-730.

Burgess L.W, Nelson PE, Toussoun TA, et al. (1988). Distribution of Fusarium Species in Sections Roseum, Arthrosporiella, Gibbosum and Discolor Recovered from grassland, pasture and pine nursery soils of Eastern Australia. Mycologia 80(6): 815-824.

Carbone I, Kohn LM. 1999. A method for designing primer sets fro speciation studies in filamentous Ascomycetes. Mycologia 91: 553-556.

Crous PW, Gams W, Stalpers JA, et al. (2004). MycoBank: an online initiative to launch mycology into the 21st century. Studies in Mycology 50(1): 19-22.

Dean R, van Kan J, Pretorious Z, et al. (2012). The Top 10 fungal pathogens in molecular plant pathology. Molecular Plant Pathology 13(4): 414-430.

Desjardins AE. 2006. Fusarium mycotoxin: chemistry, genetics, and biology. APS Press, USA.

Fisher NL, Burgess LW, Toussoun TA, et al. (1982). Carnation leaves as a substrate and for preserving cultures of Fusarium species. Phytopathology 72(1): 151-153.

Fourie G, Steenkamp ET, Gordon TR, et al. (2009). Evolutionary relationships among the Fusarium oxysporum $f$. sp. cubense vegetative compatibility groups. Applied and Environmental Microbiology 75(14): 4770-4781.

Geiser DM, Aoki T, Bacon CW, et al. (2013). One fungus, one name: defining the genus Fusarium in a scientifically robust way that preserves longstanding use. Phytopathology 103(5): 400-408.

Gerlach W, Nirenberg W (1982). The genus Fusarium--a pictorial atlas. Mitteilungen aus der Biologischen Bundesanstalt fur Land-und Forstwirtschaft Berlin-Dahlem 209: 1-406.

Handojo H, Martin JP, Wismer CA (1989). Pokkah boeng. In: Diseases of sugarcane, major disease (Ricaud C, Egan BT, Gillaspie AG Jr., Hughes CG, eds). Elsevier, US: 157-16.

Izzati MZ, Razak AA, Salleh B, et al (2008). Bakanae Disease of Rice in Malaysia and Indonesia: Etiology of the Causal Agent Based on Morphological, Physiological and Pathogenicity Characteristics. Journal of Plant Protection Research 48: 475.

Katoh K, Standley DM (2013). MAFFT multiple sequence alignment software version 7: improvements in performance and usability. Molecular biology and evolution 30(4): 772-780.

Komada H (1975). Development of a selective medium for quantitative isolation of Fusarium oxysporum from natural soil. Review of Plant Protection Research 8: 114-124.

Leslie JF, Summerell BA (2006). The Fusarium laboratory manual. John Wiley \& Sons, UK.

Leslie JF, Pearson CAS, Nelson PE, et al. (1990). Fusarium spp. from corn, sorghum, and soybean fields in the central and eastern United States. Phytopathology 80: 343-350.

Lombard L, Van der Merwe NA, Groenewald JZ, et al. (2015). Generic concept of Nectriaceae. Studies in Mycology 80: 189-245.

Maryani N, Lombard L, Poerba YS, et al. (2019). Phylogeny and genetic diversity of the banana Fusarium wilt pathogen Fusarium oxysporum f. sp. cubense in the Indonesian centre of origin. Studies in Mycology 92: 155-194. https://doi.org/10.1016/j.simyco.2018.06.003.

Miller MA, Pfeiffer W, Schwartz T (2012). The CIPRES science gateway: enabling high-impactscience for phylogenetics researchers with limited resources. In: Proceedings of the $1^{\text {st }}$ Conference of the Extreme Science and Engineering Discovery Environment: Bridging from the extreme to the campus and beyond: 1-8. Association for Computing Machinery, USA.

Nelson PE, Toussoun TA, Marasas WFO (1983). Fusarium Species: An Illustrated Manual for identification. Pennsylvania State University Press, US.

Nirenberg HI (1981). A simplified method for identifying Fusarium spp. occurring on wheat. Canadian Journal of Botany 59(9): 1599-1609.

Nirenberg HI, O'Donnell K (1998). New Fusarium Species and Combinations within the Gibberella fujikuroi species complex. Mycologia 90(3): 434-458.

O'Donnell K, Cigelnik E. (1997). Two divergent intragenomic rDNA ITS2 types within a monophyletic lineage of the fungus Fusarium are nonorthologous. Molecular Phylogenetics and Evolution 7:103-116.

O'Donnell, K, Cilgenik E, Nirenberg HI (1998a). Molecular Systematics and Phylogeography of the Gibberella fujikuroi species complex. Mycologia 90(3): 465-493.

O'Donnell K, Kistler CH, Cilgenik E, et al. (1998b). Multiple evolutionary origins of the fungus causing Panama disease of banana: Concordant evidence from nuclear and mitochondrial gene genealogies. Proceedings of the National Academy of Sciences 95(5): 2044-2049. 
O'Donnell K, Sutton DA, Rinaldi MG. et al. (2009). Novel Multilocus Sequence Typing Scheme Reveals High Genetic Diversity of Human Pathogenic Members of the Fusarium incarnatum- $F$. equiseti and $F$. chlamydosporum species complexes within the United States. Journal Clinical Microbiology 47 (12): 38513861.

O'Donnell K, Sutton DA, Rinaldi MG, et al. (2010). Internet-accessible DNA sequence database for identifying fusaria from human and animal infections. Journal of Clinical Microbiology 48(10): 3708-3718.

Onyike, NBN, Nelson PE (1993). The distribution of Fusarium species in soils planted to millet and sorghum in Lesotho, Nigeria and Zimbabwe. Mycopathologia 121(2): 105-114.

Ordonez N, Seidl MF, Waalwijk C, et al. (2015). Worse comes to worst: bananas and Panama disease-when plant and pathogen clones meet. PLoS Pathogen 11(11): e1005197.

Pinaria AG, Liew ECY, Burgess LW (2010). Fusarium species associated with vanilla stem rot in Indonesia. Australasian Plant Pathology 39(2): 176-183.

Ploetz RC (2006a). Panama disease, an old nemesis rears its ugly head: part 2, the cavendish era and beyond. Plant Health Progress March: 1-17.

Ploetz RC (2006b). Fusarium-Induced Diseases of Tropical, Perennial Crops. Phytopathology 96(6): 648-652.

Ploetz RC, Kema GHJ, Ma LJ (2015). Impact of diseases on export and smallholder production of banana. Annual Review of Phytopathology 53: 269-288.

Quaedvlieg W, Kema GHJ, Groenewald JZ, et al. (2011). Zymoseptoria gen. nov.: a new genus to accommodate Septoria-like species occurring on graminicolous hosts. Persoonia 26:57-69.

Rayner RW (1970). A mycological colour chart. Commonwealth mycological Institute, Kew, UK.

Rehner SA, Samuels GJ. (1994). Taxonomy and phylogeny of Gliocladium analysed from nuclear subunit ribosomal DNA sequences. Mycological Research 95: 625-634.

Reinking AO, Wollenweber HW (1927). Tropical Fusaria. The Philippine Journal of Science 32(2): 104-244.

Ronquist F, Telsenko M, Van Den Mark P, et al. (2012). MrBayes 3.2: efficient Bayesian phylogenetic inference and model choice across a large model space. Systematic biology 61(3): 539-542.

Snyder WC, Hansen HN (1940). The Species Concept in Fusarium. American Journal of Botany 27(2): 64-67.

Stamatakis A (2014). RAxML version 8: a tool for phylogenetic analysis and post-analysis of large phylogenies. Bioinformatics 30(9): 1312-1313.

Tamura K, Peterson D, Peterson N, et al. (2013). MEGA6: molecular evolutionary genetics analysis version 6.0 . Molecular Biology and Evolution 30(12): 2725-2729.

Vilgalys R, Hester M (1990). Rapid genetic identification and mapping of enzimatically amplified ribosomal DNA from several Cryptococcus species. Journal of Bacteriology 172: 4238-424.

Villani A, Moretti A, De Saeger S, et al. (2016). A polyphasic approach for characterization of a collection of cereal isolates of the Fusarium incarnatum-equiseti species complex. International Journal of Food Microbiology 234: 24-35.

Wang B, Brubaker CL, Burdon JJ (2004). Fusarium species and Fusarium wilt pathogens associated with native Gossypium populations in Australia. Mycological Research 108(1): 35-44.

White TJ, Bruns T, Lee S, et al. (1990). Amplification and direct sequencing of fungal ribosomal RNA genes for phylogenetics. In: Innes MA, Gelfand DH, Sninsky et al. (eds), PCR protocols: a guide to methods and applications: 315-322. Academic Press, USA.

Woudenberg JHC, Aveskamp MM, De Gruyter J, et al. 2009. Multiple Dydimella teleomorphs are linked to the Phoma clematidina morphotype. Persoonia 22:56-62.

Zakaria L, Rahman NHA (2011). Endophytic Fusarium spp. from wild banana (Musa acuminata) roots. African Journal of Microbiology Research 5(21): 3600-3602.

Zheng LS, Zhao ZH, Lu S, et al. (2012). The Fusarium species isolated from banana and their phylogenetic relationships. Mycosystema 32(4): 617-632. 


\section{Chapter 6}

\section{General discussion}


Agriculture has shaped the course of human history and civilization. In many cases, plant diseases and abiotic threats such as drought caused huge politic and economic upheavals with significant social impact as they threaten food security, especially when staple crops are affected (Zadoks 1998, Koeppel 2007, Gurr et al. 2011). Banana is one of the most consumed fruits and also a staple in many countries and was and is currently threatened by Fusarium wilt of bananas or Panama disease, one of the most destructive plant diseases (Simmonds 1962, Stover 1962, Ploetz 2015a). Controlling this disease that already spread and devastated thousands of hectares of banana plantations in many countries is of great importance. A major constituent of the manifold attempts to manage Fusarium wilt is the generation of resistant germplasm through effective and strategic breeding programs. Therefore, a diversity study of the causal fungi of Fusarium wilt on banana is critical to evaluate the incidence and efficacy of resistance and to develop management strategies.

Indonesia is the main centre origin of banana. It holds the primary diversity of wild and cultivated banana (Simmonds \& Shepherd 1955, Nasution 1990, Perrier et al. 2011). Generally, centres of host diversity coincide with centres of diversity of pathogens due to co-evolution (Grünwald \& Flier 2005, Stukenbrock \& McDonald 2008, Thrreau et al. 2009, Ali et al. 2014). Here, we focus on Fusarium wilt of bananas that is caused by a suite of the soil born fungus, previously collectively named Fusarium oxysporum f. sp. cubense (Foc). Since its first identification, many studies were conducted on Foc collections that were developed by sampling from - mostly - global monoculture plantations. However, the necessity of high diversity sampling was always pointed out (O’Donnell et al. 1998, Groenewald et al. 2006, Fourie et al. 2009, Mostert et al. 2017), but such collections were thus far not available or inaccessible. This thesis describes genetic diversity studies of Fusarium spp. associated with Fusarium wilt in native banana germplasm across the Indonesian archipelago, the centre of diversity of the genus Musa L. (Simmonds \& Shepherd 1955). This is the first and most comprehensive study addressing sympatric speciation of Fusarium spp. pathogenic on banana. We provide new insights in the taxonomy and systematics of these fungi (Chapter 2 ), studied its genetic diversity and population structure (Chapter 3) and diversity for pathogenicity (Chapter 4) and reveal other species hitchhiking with pathogenic Fusarium spp. in affected banana plants (Chapter 5). Taken together, these results shed new light on the evolutionary history of these pathogens that changes our view on the Fusarium spp. - banana pathosystem.

\section{A required change of the taxonomical status of the Fusarium spp. associated with Fusarium wilt in banana}

The systematics and taxonomy of Fusarium species has historically been an area raising substantial controversy (Nelson et al. 1994, Aoki et al. 2014). Fusarium species have been through several revisions, thus Fusarium taxonomists were divided into "splitters", "lumpers" 
and "moderates" based on their philosophy in determining Fusarium species (Gordon et al. 1994, Leslie \& Summerell 2006). Previous taxonomy studies of this genus were exclusively based on morphology, hence the division within the genus into sections and lower taxa was according to different taxonomic systems (Wollenweber \& Reinking 1935, Snyder \& Hansen 1941, Booth 1971, Gerlach \& Nirenberg 1982, Nelson et al. 1983) until the first sequencedbased Fusarium phylogeny study was introduced and established the demarcation of this genus (Guadet et al. 1989). Since then, a sequenced-based phylogeny was broadly used resulting in precise and species identification in the genus. With the current progress of whole genome sequencing and phylogeny, the genus Fusarium is suggested to comprise multiple species complexes (Geiser et al. 2013, O'Donnell et al. 2013). The Fusarium oxysporum species complex (FOSC) is one of the largest groups and accommodates agronomically important plant pathogens, but its subdivisions await formal description. Many of the agriculturally important pathogens in the FOSC are designated by host and cultivar specificity known as formae speciales and physiological race, respectively (Snyder \& Hansen 1940, Armstrong \& Armstrong 1981). However, both refer to the biology or physiology of the pathogen, which facilitates plant pathologists, but these terms have no taxonomical relevance. Combining taxonomical and pathogenicity data would reduce the confusion and facilitate the debate between pathologists and mycologists on which characteristics are necessary for systematic (Shoemaker 1981). O’Donnell et al. (1998) used multi-gene based phylogenetics for the FOSC and later showed that the strains causing Panama disease were distributed over two of its four clades, suggesting polyphyletic or multiple evolutionary origins of these strains. With the advent of contemporary genome analyses, three housekeeping genes viz. the translation elongation factor 1-alpha (tef1), RNA polymerase II largest subunit ( $r p b 1$ ), and RNA polymerase II second largest subunit ( $r p b 2)$ were proposed for phylogenetic studies (O'Donnell et al. 2015). By adopting this suggestion and expanding the sample size of FOSC from Indonesia we discovered one additional clade in the FOSC, denoted as clade 5 (Chapter 2).

The consensus is that members of FOSC are asexual (Nelson et al. 1983, Gordon \& Martyn 1997, Leslie \& Summerell 2006). However, it is unknown. Many other fungi were considered to be asexual, including Puccinia striiformis of wheat (Jin et al. 2010), Septoria passerinii (Ware et al. 2007) and Aspergillus fumigatus (O'Gorman et al. 2009) until their teleomorph were discovered or generated. Hence, the best statement would be that sexuality in members of the FOSC is unknown. A good hypothesis might be that if sexual exchange is considered, also considering that they carry the mating type alleles mat1-1 and mat1-2, Indonesia is the niche to explore. Another generally accepted opinion was that the morphological structures of FOSC members are the same. Hence, no morphological description of this species complex is available, despite numerous formae speciales and races that have been discovered. To my knowledge Nelson et al. (1983) were the last to provide a 
formal description of Fusarium oxysporum species. Combining Genealogical Concordance Phylogenetic Species Recognition (GCPSR), morphology and pathogenicity properties, we discovered nine phylogenetic species within Foc. Names and formal descriptions of these Fusarium spp., causing Fusarium wilt in bananas, were assigned (Chapter 2) and we conclude that the known Fusarium oxysporum species with pathogenicity to banana - thus previously named Foc - comprise several species (a complex) in the FOSC. It contains a unique new species F. odoratissimum that includes all Tropical Race 4 (TR4) strains that are highly pathogenic on Cavendish banana (Chapter 4). In contrast, several species - also indigenous to Indonesia - contain Race 1 strains that are highly pathogenic on Gros Michel banana (Chapters 2 \& 4). Hence, our study contributes to the taxonomy and systematic placement of Fusarium wilt pathogens of banana across the FOSC, where four out of the five recognized clades (O'Donnell et al. 1998, O'Donnell et al. 2004, Chapter 2) include Fusarium spp. associated with this important banana disease.

I do realize that taxonomy is always in flux, particularly when our knowledge increases and influences our understanding (Rosman \& Palm-Hernández 2008). Our conclusion that several phylogenetic species compose the complex of Fusarium wilt pathogens of bananas, formerly known as Foc, should gather mycologists and plant pathologists to consider my proposal to call it the Fusarium of Banana Complex (FuBC) (Chapter 2). The term "complex" is used to group/ accommodate several species with unifying characters of pathogenicity on bananas even though they are not monophyletic. This name provides more information on morphology, biology, and evolutionary relationships. The process I developed and executed could be exemplary to further look into other formae speciales (Lievens et al. 2013) to further resolve the intricate FOSC.

\section{Identifying Fusarium wilt pathogens of banana}

The FOSC comprises pathogenic and non-pathogenic strains. Thus, it is essential to correctly identify these characteristics, also for FuBC species. One could argue that Fusarium spp. isolated from a diseased plant likely belong formae speciales of that host (Wang et al. 2014, Pinaria et al. 2015). However, many strains that are isolated from roots appear to be non-pathogenic inhabitants (Snyder \& Smith 1981, Fravel et al. 2003, O’Donnell et al. 2009). Hence, extra caution in required as the chance to capture non-pathogenic strain or root inhabitants is high, particularly in the FOSC that contains many root dwelling fungi (Beckman 1987, Lievens et al. 2013). The golden standard for the identification of pathogenic strains is based on Koch's postulates comprising isolation and subsequent inoculations to reproduce the symptoms and again find isolation for comparative reason. This, however, is unfortunately frequently overlooked due to tedious and time-consuming procedures or simply because it is impossible to obtain host plants or pure fungal cultures (Hermanto et al. 2009, Mostert et al. 2017). The KNAW-SPIN program provided a platform to circumvent such limitations and hence 
we demonstrated sympatry by showing that many Fusarium spp. are pathogens of banana (Chapters 2, 3, \& 4).

Fusarium species can be recovered from a very wide range of hosts (Leslie \& Summerell 2006). It is important to carefully record the correct symptoms and administer host plants, genotypes, and geographical origin and thus limit the species that could be distinguished. We started this study with a comprehensive sampling expedition of Fusarium wilt affected bananas in Indonesia (Chapter $\mathbf{2}$ ). In order to narrow down the number of isolates and to avoid non-pathogenic root inhabitants we sampled vascular strains of the diseased plants and collected accurate information on the source and location of each sample. Using the wellestablished Fusarium Multi-Locus Sequence Typing database (Fusarium MLST, http://www.westerdijkinstitute.nl/fusarium/), partial sequences of tef1 were used as query for molecular identification of most strains. Upon the identification of FOSC members we also used $r p b 1$ and $r p b 2$ which provided a strong signal for further phylogenetic species recognition (Geiser et al. 2004, O’Donnell et al. 2013, O’Donnell et al. 2015) (Chapter 2). Once a robust identification was established, further molecular characterization (i.e. using genetic markers) and phenotypes were used to finalize the data set (Chapters $3 \& \mathbf{4})$. Despite the cheap and easy mode of current genome sequence information, it is in many cases not necessary for species recognition, but serves other goals such as phylogeographic inferences (Zheng et al. 2018).

Many formae speciales of the FOSC have traditionally been identified by using vegetative compatibility groups (VCGs) (Puhalla 1985, Leslie 2013). However, it is a laborious technique, especially for diverse populations where each individual isolate needs to be tested against a series of testers (numbers of VCGs). In many cases it is not possible and will take months or, in our case given the size of the collection, even years. Moreover, VCGs can contain both pathogenic and non-pathogenic strains towards a common host (Leslie 2006, Fourie et al. 2009). We demonstrate that VCGs and members of the FuBC do not align. Thus, a single species can contain more VCGs (Chapters 2 \& 3). With unknown underlying genotypes, VCG analyses might be suitable as a research tool, but not as an identification or diagnostic protocol and therefore further molecular identification is needed (Kistler 1997, Leslie \& Summerell 2006). It is therefore very important that a molecular diagnostic for TR4 strains, i.e. F. odoratissimum has already been developed (Dita et al. 2010) and commercialized. Recently, an even more advanced Loop mediated isothermal amplification (LAMP) diagnostic has been developed (Salacinas et al. 2018) and we confirmed that it correctly identified each and every isolate of $F$. odoratissimum irrespective of its geographical origin (Chapter 4). However, developing molecular diagnostics that could distinguish FUCB constituents in the FOSC would be very beneficial for disease management. Ideal diagnostics of pathogenic strains would be based on DNA sequences that related to pathogenicity (host-specific) rather 
than conserved genes or anonymous molecular markers (Recorbet et al. 2004, Lievens et al. 2008).

\section{Extensive genetic variation of Fusarium spp. associated with banana in Indonesia}

Until recently, there was no concern about durability of resistance to Fusarium wilt in banana. The globally grown Cavendish cultivars saved the industry due to their excellent resistance to the strains that caused the epidemic in the Americas (Koeppel 2007, Ploetz 2015b). Outbreaks in South-East Asia were neglected, and awareness was only erupting after the identification of TR4 in Jordan (García-Bastidas et al. 2014). Now, there is a broadly shared concern about accessibility and durability of resistance in the field, not only for large-scale plantations but also for subsistence farming. The extensive genetic diversity of the FuBC (Chapter 2, 3 \& 4) complicates this concern. Thus far, only a limited number of varieties is known to carry resistance to a particular species of the FuBC (Hwang \& Ko 2004, Paul et al. 2011, Smith et al. 2014). In regions where hundreds of cultivated varieties are available, like in Indonesia, subsistence farmers simply choose resistant varieties to replace susceptible ones. This practice makes disease control difficult and influences the evolution of the pathogen in such environments. As discussed above, over the course of history of Foc diversity studies, various genetic or physiological markers were used to determine variation, including physiological race, VCGs, production of volatile compounds and mating types (Ploetz 1990, Moore et al. 1991, Moore et al. 1993, Fourie et al. 2009, Cunha et al. 2015). However, ideal genetic markers are selectively neutral, polymorphic within populations, locus specific, reproducible, unambiguously to score and affordable i.e. easy to implement at reasonable cost (Brown 1996, Milgroom 2015). In chapter 2, I used DNA sequences of tef1, rpb1 and rbp2 for phylogenetic analyses of the FuBC and new phylogenetic species were identified and new taxonomic names were assigned for each species. Members of the FuBC reproduce clonally, hence species-specific mutations occur and are maintained without recombination into other genetic backgrounds (Kistler 1997). Therefore, the phylogenetic tree is accurate and can be used to represent the species and their relationship or ancestry. However, the variation between and among species needs to be assessed by other, genome-wide and many molecular markers. Therefore, genotyping-by-sequencing, using Diversity Array Technology (DArTseq) markers was chosen and to increase the resolution of these analyses. Moreover, markers can be mapped adequately to the $F$. odoratissimum TR4 reference genome and provide good coverage (Chapter 3). Cluster analyses of DArTseq markers provide an excellent resolution to discriminate genotypes within the species of FuBC. Thus, each species might contain one or more genotypes.

Genotype diversity is an important concept of plant pathogens that have a significant component of asexual reproduction in their life history (McDonald \& Linde 2002). Knowledge of genotype diversity of pathogens has direct applications in agriculture related to disease 
management and in our understanding of host pathogen biology. Fusarium spp. affecting banana are known to be highly diverse (Ploetz 1990). However, reports on this diversity have been inconsistent (Chapter 3) and incomplete due to the absence of indigenous populations from the centre of origin of banana. I demonstrate that the hitherto widest global diversity panel (24 VCGs) (Katan 1999, Ordóñez et al. 2015) comprises different species (Chapter 2) present in Indonesian populations (Chapter 3). Thus, Indonesian collection captured the widest diversity of Fusarium spp. affecting banana and supports the view that the most informative study on systematics and population biology of the pathogen is in the primary centre diversity of banana (Leslie \& Summerell 2006).

Co-evolution of plants and pathogens in their native environments results in high genetic diversity such as exemplified by the wheat pathogen Zymoseptoria tritici in the Fertile Crescent (Stukenbrock et al. 2007, Stukenbrock \& McDonald 2008), the rice blast pathogen Magnaporte grisea in the Himalayan foothills and Asia (Talbot 2003, Tharreau et al. 2009) and the coffee rust pathogen Hemileia vastatrix in Ethiophia and East Africa (Schumann \& D'Arcy 2012). This complies with our identification of eight out of nine Fusarium spp. in the FUCB in Indonesia (Chapter 2), which also comprise 10 out of 19 globally identified genotypes (Ordóñez et al. 2015; Chapter 3). However, Fusarium spp. also co-evolve in other parts of the world where banana was introduced i.e. in Africa (Chapter 2) and Latin America, with the potential emergence of new genotypes (Ordóñez et al. 2018).

Pathogenicity is a phenotypic characteristic that can be used to assess genetic variation between and within Fusarium spp. affecting banana. The hitherto physiological race nomenclature of FuBC assembled isolates with pathogenicity to Gros Michel as Race 1 strains, while isolates pathogenic on both Gros Michel and Cavendish bananas were classified as Tropical Race 4 (TR4) (Stover \& Waite 1960, Su et al. 1986). In my study, six out of nine species contained Race 1 isolates (Chapters 2 \& 4), indicating convergent pathotype evolution in genetically distinct species. F. tardichlamydosporum contained both Race 1 and Race 2 isolates (Chapter 2), suggesting that both pathotypes recently evolved from a common ancestor. However, despite the high number of isolates, diverse hosts and varying geographical origins, all TR4 strains collapsed into a single new species, F. odoratissium. This suggests that TR4 has evolved recently, but we cannot easily explain why this species is found across the Indonesian archipelago. It is likely that TR4 emerged and escaped from Sumatera to Taiwan and has spread locally, regionally, and intercontinentally from South-East Asia, particularly driven by anthropogenic factors due to the vast global Cavendish monoculture export production (Ordóñez 2015, Zheng et al. 2018). This crop has thereby become a vehicle for international TR4 dissemination, which projects a grim scenario onto the international export trade, as TR4 will almost surely surface in prone areas that are yet free of the pathogen. The risk is even higher for areas where the crop was introduced and diversity is consequently low such as the 
American continent where the least number of species is present compared to Africa and Australia where banana is a native plant (De Langhe \& De Maret 1999; Chapter 2).

\section{Sources of variation}

As mentioned above sexuality is unknown in the FOSC and was never observed or reported neither under field nor laboratory conditions. Thus, genetic diversity must result from non-sexual recombination or simply from mutation, which slows down adaptation (Leslie 2013, Milgroom 2015). However, genetic diversity was found in many different formae speciales of Fusarium oxysporum, thus in contrast to the general concept that the absence of sex prevents recombination or genetic exchange. Yet, there is clearly tremendous variation of phenotypic characters in Fusarium oxysporum, which is exceptional for an asexual fungus and these include characteristics such as host specificity (formae speciales), cultivar specificity (race), VCGs and many others. However, neither of these indicate genetic or evolutionary relatedness of these species as we demonstrated in chapters $\mathbf{2}$ and $\mathbf{3}$, albeit that $F$. oxysporum f. sp. ciceris, the causal agent of Fusarium wilt of chickpea, could be an exception as this formae speciales is monophyletic (Jiménez-Gasco et al. 2002).

I assume that co-evolution is one of the main sources driving diversification in the FuBC in Indonesia where hundreds of banana varieties are grown. In natural ecosystems, the antagonistic interaction between plants and pathogens results in dynamic co-evolutionary processes in which plants evolve to recognize pathogens and pathogens adapt to circumvent plant defence responses (Takken \& Rep 2010, Möller \& Stukenbrock 2017). This process occurs since the beginning co-occurrence of plants and pathogens and plant domestication shapes the genetic architecture of plants and pathogens. In asexual fungi, mutations or genomic rearrangements could be the primary sources of co-evolutionary processes that underlie diversity. Chromosomal number or size variants were observed in Foc isolates (Boehm et al. 1994). This karyotype diversity is likely the result of active families of transposable elements in the genome of Fusarium oxysporum, which contribute to chromosome variants (Davière et al. 2001, van Dam et al. 2018).

The polyphyletic structure of the FuBC, and likely many other formae speciales, was identified by using the DNA sequence of conserved genes and indicates that the evolutionary proximity of species with pathogenicity towards unrelated hosts is smaller than between species infecting a common host. Indeed, horizontal gene transfer (HGT) events have been reported in many FOSC species (van der Does \& Rep 2007, Ma et al. 2010, Vlaardingerbroek et al. 2016, van Dam \& Rep 2017), particularly in Fusarium oxysporum f. sp. lycopersici (Fol) where it has been well studied. The tomato - Fol pathosystem complies with the gene-forgene (GFG) mechanism of host - pathogen interactions. The main virulence factors are located on a pathogenicity chromosome that can be shuttled among Fol strain and even between different Fusarium oxysporum ff. spp. As root and soil inhabitants, many Fusarium oxysporum 
ff. spp., comprising pathogens and non-pathogens, co-inhabit the same niche, which increases the chance for HGT. We collected Fusarium isolates from many different banana-planting systems in Indonesia. These various ecosystems are made up by manifold plant species, including host and non-host plants (Chapter 2), thereby creating a conducive environment for HGT to occur as pointed out by Vlaardingerbroek et al. (2016). The variation of the genome size and chromosome numbers in FuBC species (Miao 1990), reflect the high possibility of HGT within and between species. Future studies on the genomic compositions of each species of the FuBC could reveal whether HGT occurred or is required for the pathogenicity of the constituent Fusarium species on bananas.

Native populations of pathogens should be capable of sustaining more genetic variation as they will not be subjected to uniformity and intense selection pressure associated with agricultural monocultures (Stukenbrock \& McDonald 2008, Summerell et al. 2010). Such ecological settings are exemplary for Indonesian banana farming systems (Chapter 2). Despite the limitation of an absent sexual cycle, asexual fungi can undergo anastomosis and subsequently parasexual exchange (mitotic crossing over), which does occur in native populations of plant pathogens (Talbot 2003). Brankovics et al. (2017) recently suggested parasexuality for species in the FOSC, but Buxton (1962), who was intrigued by the wide variation of culture characteristics and pathogenicity of $F$. oxysporum $f$. sp. cubense on different banana cultivars, already demonstrated that strains pathogenic on Gros Michel bananas could undergo asexual recombination under laboratory condition. Finally, Taylor et al. (1999) conclude that little resolution, low support for clades and incongruence of individual gene genealogies are indicators of asexual recombination of FuBC species under natural conditions. In my analyses of extensive data sets we used gene genealogies for a phylogenetic species concept (Chapter 2) and observed low support for Fusarium purpurascens and $F$. phialophorum; a condition consistent with recombination (Koenig et al. 1997, Taylor et al. 1999). Nonetheless, we described them as distinct phylogenetic species due to sequence support and because they were previously recognised as a lineage/cryptic species (O'Donnell et al. 1998, Fourie et al. 2009). Moreover, Fourie et al. (2009) observed that FuBC species harbour either of the two-mating type idiomorphs mat1-1 and mat1-2 but that some lineages contain both alleles and are therefore functionally heterothallic. This suggests that these species have been or will be able to undergo sexual reproduction.

\section{Pathogenicity variation}

Over the past years several approaches determined genetic variation in FuBC species, but the underlying mechanism remain poorly understood (Moore et al. 1993, Bentley et al. 1998, Groenewald et al. 2006, Fourie et al. 2009, Mostert et al. 2017). Here, we demonstrate that high resolution genotyping provides a solid identification of individual species and genotypes in natural populations (Chapters 2 \& 3), which should be generally adopted as a 
standard identification and characterization method for Fusarium species involved in the complex banana - Fusarium spp. pathosystem. The next important step is to determine genetic variation for pathogenicity towards diverse banana accessions, which is critical for appropriate disease management and indispensable for developing resistance breeding strategies. Well-characterized strains are necessary for any forward strategy for improving disease resistance (Russell 1978, Brown 2002), and the banana - Fusarium spp. pathosystem is no exception. However, previously, pathogenic variation in the FuBC was not fully assessed due to the low experimental amenability, and the absence of differential banana varieties (Ploetz 2015a). Neither the interaction nor the genetic basis of pathogenicity is well understood in this pathosystem. Until recently, not a single gene for resistance to Fusarium wilt had been mapped. Dale et al. (2017) successfully identified and transferred a major gene for resistance from $M$. acuminata ssp. malaccensis, the wild diploid species endemic in Sumatra, to Cavendish banana. Sutanto (2014) isolated and characterized resistance gene analogues (RGAs) from Pisang Rejang and Calcutta4. Defence gene analogue (DGAs) were also isolated from local varieties Klutuk Wulung, Pisang Kepok, Ambon Hijau and Rejang (Sutanto 2014), making them prime interest targets for future gene identifications.

A new standardized phenotyping protocol enabled the screening of hundreds of banana accessions, facilitating the analysis of large segregating populations under greenhouse conditions (Chapter 4, Ahmad et al. in prep., Garcia-Bastidas et al. in prep.). These are the first cornerstones for an increased understanding of genetic diversity for pathogenicity in the FuBC, as genomic resolution without appropriate phenotyping tools is an emptyhanded precision. Our contribution is substantial as we screened 78 isolates across the FuBC to four banana accessions and confirmed large differences in pathogenicity that overall overlapped the so-called Race 1 and TR4 pathotypes, which all belong to the newly described species $F$. odoratissimum, as well as quantitative variation (Chapter 4). Contrary to the tomato - Fol pathosystem (Houterman et al. 2009), the genetic basis of the host- pathosystem for hundreds of Fusarium oxysporum ff. spp. is unclear (Armstrong \& Armstrong 1981) and only a few comply with GFG, such as F. oxysporum f. sp. melonis - melon, F. oxysporum f. sp. cucumerinum -cucumber, F. oxysporum f. sp. pisi - pea, and F. oxysporum f. sp. niveum - watermelon (Michielse \& Rep 2009). Thus, the majority of race determinations solely rely on assays and the underlying genetic basis for pathogenicity and host resistance is unknown. The FuBC banana system is therefore just at the start of a deeper understanding that should be the basis for progress towards a much more sustainable global banana production. Clearly, genetic studies have to continue and more differential banana accessions should be added to the test panel to further reveal the widest possible pathogenicity landscapes. Compared to other formae speciales, FuBC has the least number of host varieties to be used in phenotyping assays (Stover \& Waite 1960, Su et al. 1986). However, genomic research will also reveal effector proteins that will further professionalize and extend the FuBC pathogenicity map. 
Comparative analyses with the closely related Fol - tomato pathosystem revealed homologs of the secreted in xylem (SIX) effector proteins which interact with host receptors (FraserSmith et al. 2014, Czislowski et al. 2018). However, these studies are based on whole genome profiles of FuBC species, which do not unveil their role during pathogenesis. In another study, using only one susceptible banana variety, Guo et al. (2014) report that a set of SIX genes is expressed during infection. Recently, Widinugraheni et al. (2018, in prep.) showed that SIX1 alleles contribute to aggressivness of $F$. odoratissimum. However, these effectors are not crucial for the presumed GFG that results in complete resistance to F. odoratissimum in the wild accessions $M$. acuminata ssp. malaccensis to F. grosmichelii in Cavendish. Hence, further studies are required to demonstrate the role of these and other genes in the defence response. Comparative genomics will be crucial for further identification and understanding of FuBC effector genes, similar to other Fusarium pathosystems (Rep \& Kistler 2010), particularly since the Race 1 strains belong to six FuBC species, which might be due to HGT. The global dissemination of TR4 is therefore a great concern as HGT may potentially turn other FuBC species into Cavendish killer strains.

As a matter of fact, Gros Michel is susceptible to a broad suite of Fusarium species while Cavendish is susceptible to just $F$. odoratissimum (Chapter 4 ). This is one of the best examples of durable resistance (Jonson 1984, McDonald \& Linde 2002) as Cavendish is cultivated on Race 1 infested soils around the world for decades. Contrary to the epidemiological dogma's and expectations, selection pressure has until now not resulted in Fusarium strains that overcome the resistance of this banana variety. Hence, it is worthwhile and necessary to understand how selection pressure on soil-borne pathogens is being operationalized. Is it for instance, not as strong because they can easily survive as endophytes in non-host plants (Gordon et al. 1989). In any case, the current pandemic truly results from new intrusions of another Fusarium species. Therefore, increased insight in the epidemiological processes, genetic variability and selection pressure is necessary to anticipate the durability of any source of resistance, including genes from wild banana accessions (Dale et al. 2017) with impressive efficacies to TR4 (Chapter 4, Zuo et al. 2018) such as M. acuminata ssp. malaccensis (Pahang), the cultivated variety Pisang Rejang and many others (Handayani et al. 2017).

\section{Diversity of Fusarium species hitchhiking with Fusarium wilt pathogens of banana}

The incidence and abundance of Fusarium species has been well documented for almost all plant species and in soil (Bacon \& Yates 2006, Leslie \& Summerell 2006, Ploetz 2006). Members of this genus have adapted to a wide range of ecological conditions and hosts. They are the primary cause of root, stem, and leaf diseases of many agriculturally important crops (Marasas et al. 2006, Ploetz 2006). Besides being pathogens, many of these fungi are also known to grow as endophytes in non-host plants (Leslie et al. 1990, Zakaria et al. 2011). In 
host-fungal pathogen systems, most attention - obviously - is directed towards causal agents in mycological studies. Albeit that microbiome studies may have a broader view, they usually focus on bacterial communities (Turner et al. 2013, Hardoim et al. 2015). Consequently, many endophytic Fusarium species are generally overlooked and therefore, their role during the early symptomless phase of pathogenesis is unknown. However, once symptoms become apparent, Fusarium species isolated from these infected materials are frequently considered to be the causal agents. Without subsequent inoculation studies such assumptions are at least questionable (Brader et al. 2017). Reports on non-pathogenic Fusarium species from diseased plants are scarce (Pinaria et al. 2010, Wang et al. 2014). In chapter 5, we identified 20 Fusarium isolates from banana plant with Fusarium wilt symptoms and concluded that they belong to the $F$. fujikuroi (FFSC), the $F$. incarnatum-equisetii (FIESC), and the $F$. sambucinum species complexes (FSSC). Many of these Fusarium species are well-known pathogens associated with other crops, also commonly cultivated in Indonesia (e.g. F. fujikuroi, F. sacchari and $F$. verticilloides on sugar cane, maize and rice, respectively), but were never reported in banana. Our assumption is that these species enter affected tissue and hence hitchhike with Fusarium spp. associated with banana, but they could also facilitate pathogenesis of these species while dwelling as endophytes in banana. Further experimentation should reveal which option is most likely.

\section{Conclusions and direction of future research}

Diversity analyses of plant pathogens in their centre of origin are crucial for understanding the complexity of host - pathogen relationship. This thesis gives a first impression of the enormous diversity of the $\mathrm{FuBC}$ in the Indonesian centre of origin of banana. However, this is only a start. Extending knowledge on the extensive diversity of the causal fungi should bridge the gap of understanding their co-evolution with hundreds of bananas varieties. Therefore, Indonesian banana germplasm is also a source for resistance, albeit that many local varieties are very susceptible, hundreds of varieties are potentially resistant to one or more constituent FuBC species, which should be explored in much more detail.

The fundamental taxonomical aspects of this study provide basic knowledge that can be used by plant pathologist, mycologist and breeders. The proposed FuBC unifies Fusarium wilt pathogens of bananas and could accommodate taxonomy and pathology standpoints in various other species and formae speciales of the FOSC. Finally, many asexual fungi turned out to have a secret sex life. Therefore, attempting sex with FuCB species is a challenging but worthwhile exploration, particularly under natural conditions in Indonesia. Clearly, fungal genetics would facilitate building the required underlying foundation for the genetic improvement of the crop. On the other hand, in case sex would not work out, which is likely, progress can be guaranteed by continuing building a sound basis of multidisciplinary projects in a stimulating environment and optimal critical mass to further explore the beauty and 
challenges of the banana - FuBC pathosystem. This should include high-throughput host and pathogen genomics in parallel with the latest genetic technologies to unravel their interaction, including genome editing, functional studies and crop improvement. The current study is an excellent example how curiosity can push progress in many under-investigated and yet significant problems with other Fusarium pathogens in tropical crops.

\section{References}

Ali S, Gladieux P, Leconte M, Gautier A, Justesen AF, Hovmøller MS, et al. (2014). Origin, migration routes and worldwide population genetic structure of the wheat yellow rust pathogen Puccinia striiformis f. sp. tritici. PLOS Pathogens 10(1): e1003903.

Aoki T, O'Donnell K, Geiser GM, et al. (2014). Systematics of key phytopathogenic Fusarium species: current status and future challenges. Journal of General Plant Pathology 80(3): 189-201.

Armstrong GM, Armstrong JK (1981). Formae speciales and races of Fusarium oxysporum causing wilt diseases. In: Fusarium: Diseases, Biology and taxonomy (Nelson PE, Toussoun TA, Cook RJ, eds). The Pennsylvania State University Press, USA: 391-399.

Bacon CW, Yates IE (2006). Endophytic root colonization by Fusarium species: Histology, plant interactiin, and toxicity. In : Microbial root endophytes (Schulz B, Boyle C, Sieber T, eds) Springer, Germany : 133-152.

Beckman CH (1987). The nature of wilt diseases of plants. The American Phytopathological Society, Minnesota, USA.

Bentley S, Pegg K, Moore N, Davis R, Buddenhagen I. (1998). Genetic variation among vegetative compatibility groups of Fusarium oxysporum f. sp. cubense analyzed by DNA fingerprinting. Phytopathology, 88(12), 1283-1293.

Boehm EWA, Ploetz RC, et al. (1994). Statistical analysis of electrophoretic karyotype variation among vegetative compatibility groups of Fusarium oxysporum f. sp. cubense. Molecular Plant Microbe Interactions 7(2): 196-207.

Brader G, Compant S, Vescio K, et al. (2017). Ecology and genomic insights into plant-pathogenic and plantnonpatogenic endophytes. Annual Review of Phytopathology. 55: 61-83.

Brankovics B, Van Dam P, Rep M, et al. (2017). Mitochondrial genomes reveal recombination in the presumed asexual Fusarium oxysporum species complex. BMC Genomics 18(1): 735.

Brown JKM (1996). The choice of molecular marker methods for population genetic studies of plant pathogens. New Phytologist 133(1): 183-195.

Brown JKM (2002). Yield penalties of disease resistance in crops. Current opinion in Plant Biology 5(4): 339-344.

Buxton EW (1962). Parasexual recombination in the banana-wilt Fusarium. Transactions of the British Mycological Society 45(2):274-279.

Cunha CMS, Hinz RH, Pereira A, et al. (2015). Aggressiveness and genetic diversity of Fusarium oxysporum f. sp. cubense from Santa Catarina, southern Brazil. Tropical Plant Pathology 40(5): 326-334.

Czislowski E, Fraser-Smith S, Zander M, et al. (2018). Investigation of the diversity of effector genes in the banana pathogen, Fusarium oxysporum f. sp. cubense, reveals evidence of horizontal gene transfer. Molecular plant pathology 19(5): 1155-1171.

Dale J, James A, Paul JY, et al. (2017). Transgenic Cavendish bananas with resistance to Fusarium wilt tropical race 4. Nature communications $8(1)$ : 1496.

Davière JM, Thierry L, Daboussi MJ (2001). Potential role of transposable elements in the rapid reorganization of the Fusarium oxysporum genome. Fungal Genetics and Biology 34(3): 177-192.

De Lange E, De Maret P. 1999. Tracking the banana: its significance in early agriculture. In, The prehistory of food: appetites for change (Gosten C, eds). London: One world archeology. Pp: 377-396.

Dita M, Waalwijk C, Buddenhagen I, Souza Jr M, Kema GHJ (2010). A molecular diagnostic for tropical race 4 of the banana fusarium wilt pathogen. Plant Pathology, 59(2), 348-357.

Fourie G, Steenkamp ET, Gordon TR, et al. (2009). Evolutionary relationships among the Fusarium oxysporum $\mathrm{f}$. sp. cubense vegetative compatibility groups. Applied and Environmental Microbiology 75(14): 4770-4781.

Fraser-Smith S, Czislowski E, Meldrum RA, et al. (2014). Sequence variation in the putative effector gene SIX8 facilitates molecular differentiation of Fusarium oxysporum f. sp. cubense. Plant Pathology 63: 1044-1052.

Fravel D, Olivain C, Alabouvette C (2003). Fusarium oxysporum and its biocontrol. New Phytologist 157: 493-502. 
García-Bastidas F, Ordóñez N, Konkol J, Al-Qasim M, Naser Z, Abdelwali M, et al. (2014). First report of Fusarium oxysporum f. sp. cubense tropical race 4 associated with Panama disease of banana outside Southeast Asia. Plant Disease 98(5): 694.

García-Bastidas F, Alexander V, Nakasato TG, et al., (2018). A high throughput phenotyping method for the banana - Fusarium oxysporum f. sp. cubense pathosystem, with wider application for other Fusarium oxysporum - host relationships. In preparation.

Geiser DM, Aoki T, Bacon CW, et al. (2013). One fungus, one name: defining the genus Fusarium in a scientifically robust way that preserves longstanding use. Phytopathology 103(5): 400-408.

Geiser DM, Jiménez-Gasco MM, Kang S, et al. (2004). FUSARIUM-ID v. 1.0: A DNA sequence database for identifying Fusarium. European Journal of Plant Pathology 110(5): 473-479.

Gerlach W, Nirenberg H (1982). The Genus Fusarium - A Pictorial Atlas. Mitteilungen aus der Biologischen Bundesanstalt fur Land-und Forstwirtschaft Berlin-Dahlem 209: 1-406.

Grünwald N.J., Flier W.G. (2005). The biology of Phytophthora infestans at its center of origins. Annual Review Phytopathology 43: 171-190.

Gordon TR, Okamoto D, Jacobson DJ (1989). Colonization of muskmelon and nonsusceptible crops by Fusarium oxysporum f. sp. melonis and other species of Fusarium. Phytopathology 79: 1095-1100.

Gordon TR, Martyn RD (1997). The evolutionary biology of Fusarium oxysporum. Annual Reviews Phytopathology 35: 111-128.

Gordon TR (2017). Fusarium oxysporum and the Fusarium wilt syndrome. Annual Reviews of Phytopathology 55: 23-39.

Groenewald S, Van Den Berg N, Marasas WFO, et al. (2006). The application of high-throughput AFLP's in assessing genetic diversity in Fusarium oxysporum f. sp. cubense. Mycological Research 110(3): $297-305$.

Grünwald NJ, Flier WG (2005). The biology of Phytophthora infestans at its center of origin. Annual Reviews Phytopathology 43: 171-190.

Guadet J, Julien J, Lafay JF, Brygoo Y (1989). Phylogeny of some Fusarium species, as determined by large-subunit rRNA sequence comparison. Molecular Biology Evolution 6(3): 227-242.

Guo L, Han L, Yang L, et al. (2014). Genome and transcriptome analysis of the fungal pathogen Fusarium oxysporum f. sp. cubense causing banana vascular wilt disease. PloS one 9(4): e95543.

Gurr S, Samalova M, Fisher M (2011). The rise and rise of emerging infectious fungi challenges food security and ecosystem health. Fungal Biology Reviews 25: 181-188.

Handayani T, Martanti D, Poerba YS, et al. (2017). Deteksi awal ketahanan beberapa aksesi pisang lokal dan hasil persilangan terhadap penyakit layu Fusarium (Foc VCG 01213/16 TR4). Journal Hortikultura Indonesia 8(2): 88-96.

Hardoim PR, van Overbeek LS, Berg G, et al. (2015). The hidden world within plants: ecological and evolutionary considerations for defining functioning of microbial endophytes. Microbiology and Molecular Biology Reviews 79(3): 293-320.

Hermanto C, Sutanto A, Jumjunidang, et al. (2009). Incidence and distribution of Fusarium wilt disease of banana in Indonesia. International ISHS-ProMusa Symposium on Global Perspectives on Asian Challenges 897: 313-322.

Houterman PM, Ma L, Dekker D, et al. (2007). The effector protein Avr2 of the xylem-colonysing fungus Fusarium oxysporum activates the tomato resitance protein I-2 intracellularly. Plant Journal 58: 970-978.

Hwang SC, Ko WH (2004). Cavendish banana cultivars resistant to Fusarium wilt acquired through somaclonal variation in Taiwan. Phytopathology 88(6): 580-588.

Jhonson R (1984). A critical analysis of durable resistance. Annual Reviews Phytopathology 22: 309-330.

Jiménez-Gasco MM, Milgroom MG, Jiménez-Diaz RM (2002). Gene genealogies support Fusarium oxysporum $\mathrm{f}$. sp. ciceris as a monophyletic group. Plant Pathology 51(1): 72-77.

JinY, Szabo LJ, Carson M (2010). Century-old mystery of Pusccinia stiiformis life history solved with identification of Berberis as an alternate host. Phytopathology 100: 432-435.

Katan T (1999). Current status of vegetative compatibility groups in Fusarium oxysporum. Phytoparasitica 27(1): 51-64.

Kistler HC (1997). Genetic diversity in the plant-pathogenic fungus Fusarium oxysporum. Phytopathology 87(4): 474-479.

Koenig R, Ploetz R, Kistler HC (1997). Fusarium oxysporum f. sp. cubense consists of a small number of divergent and globally distributed clonal lineages. Phytopathology 87(9): 915-923.

Koeppel D (2007). Banana: The fate of the fruit that changed the world. Hudson Street Press, New York, USA

Leslie JF, Summerell BA (2006). The laboratory Fusarium manual. Blackwell Publishing USA. 
Leslie JF, Pearson CAS, Nelson PE, et al. (1990). Fusarium spp. from corn, sorghum, and soybean fields in the central and eastern United States. Phytopathology 80: 343-350.

Leslie JF (2013). Genetics and Fusarium oxysporum. In: Fusarium wilts of greenhouse vegetable and ornamental crops. (Gullino ML, Katan J, Garibaldi A, eds). The APS press, Minnesota, USA: 39-46.

Lievens B, rep M, Thomma B (2008). Recent developments in the molecular discrimination of formae speciales of Fusarium oxysporum. Pest Management Science 64(8): 781-788.

Lievens B, Hanssen IM, Rep M (2013). Recent developments in the detection and identification of formae speciales and races of Fusarium oxysporum: from pathogenicity testing to molecular breeding. In: Fusarium wilts of greenhouse vegetable and ornamental crops. (Gullino ML, Katan J, Garibaldi A, eds). The APS press, Minnesota, USA: 47-55.

Ma LJ, Van Der Does HC, Borkovich KA, et al. (2010). Comparative genomics reveals mobile pathogenicity chromosomes in Fusarium. Nature 464(7287): 367-373.

Marasas WFO, Ploetz RC, Wingfield MJ, et al. (2006) Mango malformation disease and the associated Fusarium species. Phytopathology 96(6): 667-672.

McDonald BA, Linde C (2002). Pathogen population genetics, evolutionary potential, and durable resistance. Annual Review of Phytopathology 40(1): 349-379.

Miao VPW (1990). Using karyotype variability to investigate the origin and relatedness of isolates of Fusarium oxysporum f. sp. cubense. In: Fusarium wilt of banana (Ploetz RC, eds). APS Press.

Michielse CB, Rep M (2009). Pathogen profile update: Fusarium oxysporum. Molecular plant pathology 10(3): 311-324.

Milgroom MG (2015). Population biology of plant pathogens: Genetics, Ecology, and Evolution. The American Phytopathological Society, Minnesota, USA.

Möller M, Stukenbrock EH (2017). Evolution and genome architecture in fungal plant pathogens. Nature Reviews Microbiology 15: 756.

Moore NY, Hargreaves PA, Pegg KG, et al. (1991). Characterisation of strains of Fusarium oxysporum f. sp. cubense by production of volatiles. Australian journal of botany 39(2): 161-166.

Moore NY, Pegg KG, Allen RN, et al. (1993). Vegetative compatibility and distribution of Fusarium oxysporum f. sp. cubense in Australia. Animal Production Science 33(6): 797-802.

Mostert D, Molina A, Daniells J, et al. (2017). The distribution and host range of the banana Fusarium wilt fungus, Fusarium oxysporum f. sp. cubense, in Asia. PLoS ONE 12(7) e0181630.

Nasution RE (1990). A Taxonomic Study of the Species Musa Acuminata Colla with its Intraspesific Taxa in Indonesia. Ph.D dissertation. Tokyo University of Agriculture, Japan.

Nelson PE, Dignani MC, Anaissie EJ (1994). Taxonomy, biology, and clinical aspects of Fusarium species." Clinical Microbiology Reviews 7(4): 479-504.

O'Donnell K, Kistler CH, Cilgenik E, et al. (1998). Multiple evolutionary origins of the fungus causing Panama disease of banana: Concordant evidence from nuclear and mitochondrial gene genealogies. Proceedings of the National Academy of Sciences of the USA 95(5): 2044-2049.

O'Donnell K, Sutton DA, Rinaldi MG, et al. (2004). Genetic diversity of human pathogenic members of the Fusarium oxysporum complex inferred from multilocus DNA sequence data and amplified fragment length polymorphism analyses: evidence for the recent dispersion of a geographically widespread clonal lineage and nosocomial origin. Journal of Clinical Microbiology 42(11): 5109-5120.

O'Donnell K, Sutton DA, Rinaldi MG, et al. (2009). A two-locus DNA sequence database for typing plant and h11man pathogens within the Fusarium oxysporum species complex. Fungal Genetics and Biology 46: $936-$ 948.

O'Donnell K, Rooney AP, Proctor RH, et al. (2013). Phylogenetic analyses of RPB1 and RPB2 support middle Cretaceous origin for a clade comprising all agriculturally and medically important fusaria. Fungal Genetics and Biology 52(0): 20-31.

O'Donnell K, Todd J, Robert V, et al. (2015). DNA sequence-based identification of Fusarium: Current status and future directions. Phytoparasitica 43(5): 583-595.

O'Gorman CM, Fuller HT, Dyer PS (2009). Discovery of a sexual cycle in the opportunistic fungal pathogen Aspergillus fumigatus. Nature 457: 471-475.

Ordóñez N, Seidl MF, Waalwijk C, et al. (2015). Worse comes to worst: bananas and Panama disease-when plant and pathogen clones meet. PLoS Pathogens 11(11): e1005197.

Ordóñez N. (2018). A global genetic diversity analysis of Fusarium oxysporum f. sp. cubense, the Panama disease pathogen of banana. Ph.D dissertation. Experimental Plant Sciences, Wageningen University, The Netherlands.

Paul JY, Becker DK, Dickman MB, Harding RM, Khanna HK, Dale JL (2011). Apotopsis-related genes confer 
resitance to Fusarium wilt in transgenic 'Lady Finger' bananas. Plant Biotechnology Journal 9: 1141-1148.

Perrier X, De Langhe E, Donohue M, et al. (2011). Multidisciplinary perspectives on banana (Musa spp.) domestication. Proceedings of the National Academy of Sciences of the USA 108(28): 11311-11318.

Pinaria AG, Liew ECY, Burgess LW (2010). Fusarium species associated with vanilla stem rot in Indonesia. Australasian Plant Pathology 39(2): 176-183.

Pinaria AG, Laurence MH, Burgess LW, et al. (2015). Phylogeny and origin of Fusarium oxysporum f. sp. vanillae in Indonesia. Plant Pathology 64(6): 1358-1365.

Ploetz RC (1990). Variability in Fusarium oxysporum f. sp. cubense. Canadian Journal of Botany 68(6): $1357-1363$.

Ploetz RC (2006). Fusarium-induced diseases of tropical, perennial crops. Phytopathology 96(6): 648-652.

Ploetz RC (2015a). Fusarium wilt of banana. Phytopathology 105(12): 1512-1521.

Ploetz RC (2015b). Management of Fusarium wilt of banana: A review with special reference to tropical race 4. Crop Protection 72: 7-15.

Puhalla JE (1985). Classification of strains of Fusarium oxysporum on the basis of vegetative compatibility. Canadian Journal of Botany 63(2): 179-183.

Recorbet G, Steinberg C, Olivain C, et al. (2003). Wanted: pathogenesis-related marker molecules for Fusarium oxysporum. New Phytologist 159(1): 73-92.

Rep M, Kistler C (2010). The genomic organization of plant pathogenicity in Fusarium species. Current opinion in Plant Biology 13: 420-426.

Rosman AY, Palm-Hernández ME (2008). Systematics of plant pathogenic fungi: Why it matters. Plant Disease 92(10): 1376-1386.

Russell GE (1978). Plant breeding for pest and disease resistance. London.

Salacinas M, Ordóñez N, Mendes O, et al. (2018). A loop-mediated isothermal amplification assay based on unique markers derived from genotyping-by-sequencing data for rapid in-plant diagnosis of Fusarium oxysporum f. sp. cubense tropical race 4 in banana. Submitted

Schlötterer C (2004). The evolution of molecular markers-just a matter of fashion?. Nature Reviews Genetics 5(1): 63-69.

Schuman GL, D'Arcy CJ (2012). Hungry planet: stories of plant diseases. The APS press, Minnesota, USA.

Shoemaker RA (1981). Changes in taxonomy and nomenclature of important genera of plant pathogens. Annual Reviews Phytopathology 19: 297-307.

Simmonds N. (1962). The Evolution of Bananas. London: Longman Itd.

Simmonds N, Shepherd K (1955). The taxonomy and origins of the cultivated bananas. Journal of the Linnean Society of London, Botany 55: 302-312.

Smith MK, Langdon PW, Pegg KG, Daniells JW (2014). Growth, yield and Fusarium resistance of six FHIA tetraploid bananas (Musa spp.) grown in the Australian subtropics. Scientia Horticulturae 170: 176-181.

Snyder WC, Hansen HN (1940). The Species Concept in Fusarium. American Journal of Botany 27(2): 64-67.

Stover RH (1962). Fusarial wilt (Panama Disease) of bananas and other Musa species. Oxford university press, Oxford, UK.

Stover R, Waite B (1960). Studies on Fusarium wilt of bananas: V. Pathogenicity and distribution of Fusarium oxysporum f. cubense Races 1 and 2. Canadian Journal of Botany 38(1): 51-61.

Stukenbrock EH, Banke S, Javan-Nikhah M et al. (2007). Origin and domestication of the fungal wheat pathogen Mycosphaerella graminicola via sympatric speciation. Molecular biology and evolution 24(2): 398-4

Stukenbrock EH, McDonald BA (2008). The origins of plant pathogens in agro-ecosystems. Annual Review of Phytopathology 46: 75-100.

Sutanto A (2014). Karakterisasi molekular ketahanan beberapa kultivar pisang (Musa spp.) terhadap penyakit layu panama (Fusarium oxysporum f. sp. cubense). Ph.D dissertation. Bogor Agricultural University, Indonesia.

Su Hj, Hwang SC, Ko WH (1986). Fusarial wilt of Cavendish bananas in Taiwan. Plant Disease 70(9): 814-818.

Takken F, Rep M (2010). The arms race between tomato and Fusarium oxysporum. Molecular plant pathology 11(2): 309-314.

Talbot NJ (2003). On the trail of a cereal killer: exploring the biology of Magnaporthe grisea. Annual Review of Microbiology 57(1): 177-202.

Taylor J, Jacobson DJ, Fisher MC (1999). The evolution of asexual fungi: reproduction, speciation and classification. Annual Review of Phytopathology 37(1): 197-246.

Tharreau D, Fusal I, Andriantsimialona D, et al. (2009). World population structure and migration of the rice blast fungus, Magnaporthe oryzae. In: Advances in genetics, genomics and control of rice blast disease (Wang GL, Valent B, eds). Springer, Dordrecht: 209-215.

Turner TR, James EK, Poole PS (2013). The plant microbiome. Genome Biology 14: 209. 
van Dam $P$, de sain M, Ter Horst A, et al. (2018). Use of comparative genomics-based markers for discrimination of host specificity in Fusarium oxysporum. Applied and Environmental Microbiology 84(1): e01868-17.

van Dam P, Rep M (2017). The distribution of miniature impala elements and SIX genes in the Fusarium genus is suggestive of horizontal gene transfer. Journal of Molecular Evolution doi:10.1007/s00239-017-9801-0.

van der Does HC, Rep M (2007). Virulence genes and the evolution of host specificity in plant-Pathogenic Fungi. Molecular Plant-Microbe Interactions 20(10): 1175-1182.

Vlaardingerbroek I, Beerens B, Rose L, et al. (2016). Exchange of core chromosomes and horizontal transfer of lineage-specific chromosomes in Fusarium oxysporum. Environmental Microbiology 18(11): 3702-3713.

Wang B, Brubaker CL, Burdon JJ (2004). Fusarium species and Fusarium wilt pathogens associated with native Gossypium populations in Australia. Mycological Research 108(1): 35-44.

Ware SB, Verstappen ECP, Breeden J, Cavaletto JR, Goodwin Sb, Waalwijk C, et al. (2006). Discovery of a functional Mycosphaerella teleomorph in the presumed asexual barley pathogen Septoria passerinii. Fungal genetics and Biology 44(389-397).

Widinugraheni S, Sanchez JN, van DerDose HC, et al. (2018). A SIX1 homolog of Fusarium oxysporum f. sp. cubense tropical race 4 contributes to virulence towards Cavendish banana. In preparation.

Wollenweber HW, Reinking OA. (1935). Die Fusarien, ihre Beschreibung, Schadwirkung, und 677 Bekämpfung. Paul Parey, Berlin.

Zadoks JC (1998). On the political economy of plant disease epidemics, capita selecta in historical epidemiology. Wageningen Academic Publisher, The Netherlands.

Zakaria L, Rahman NHA (2011). Endophytic Fusarium spp. from wild banana (Musa acuminata) roots. African Journal of Microbiology Research 5(21): 3600-3602.

Zheng SJ, Garcia-Bastidas FA, Li X, et al. (2018). New geographical insights of the latest expansion of Fusarium oxysporum f. sp. cubense Tropical Race 4 Into the greater Mekong subregion. Frontiers in Plant Science 9(457).

Zuo C, Deng G, Li B, et al. (2018). Germplasm screening of Musa spp. for resistance to Fusarium oxysporum f. sp. cubense tropical race 4 (Foc TR4). European Journal Plant Pathology, https://doi.org/10.1007/s10658-0171406-3. 



\section{Summary}

Banana is one of the most consumed fruits and also a staple in many countries. Sustaining banana production is important to supply domestic and international markets, which support the livelihood of millions of smallholder farmers. The most beloved fruit was and is currently devastated by one of the most threatening plant diseases in history called Fusarium wilt or Panama disease. The disease is caused by a suite of soil born fungi, previously collectively known as Fusarium oxysporum f. sp. cubense (Foc). A prime strategy to manage the ongoing pandemic of the disease that has devastated thousands of hectares of banana plantations in many countries is the generation of resistant banana varieties. Therefore, more knowledge on the diversity of the causal fungi is indispensable. Indonesia is the main centre of origin of banana where hundreds of wild and cultivated varieties are grown across the entire archipelago. Generally, the centres of diversity of hosts and pathogens overlap. Thus, Indonesia is the primary region to study the diversity of the pathogens causing Panama disease due to their co-evolution with the banana hosts. This thesis provides some of the most informative studies on the genetic diversity and phylogeny of Fusarium spp. associated with Panama disease. It contributes to the knowledge on the systematics of Fusarium species with pathogenicity to banana, their genotypic diversity and pathogenicity, as well as on nonpathogenic Fusarium spp. hitchhiking with pathogenic species in the interior of banana stems.

In chapter 1, I describe the current state of art of banana research and the related Fusarium pathogens. Also, the history and early domestication of banana, its production and importance as a fruit crop commodity are described. This is then connected with Fusarium wilt as one of the main constraints, culminating in the importance and urgency of studying the diversity of the causal pathogens in Indonesia.

Chapter 2 describes a sampling expedition to sample Fusarium wilt affected banana plants across 34 geographical locations of the main banana producing areas in Indonesia on Java, Flores, Kalimantan, Papua, Sumatra and Sulawesi. More than 200 Fusarium isolates were recovered from many local varieties that suffered from the disease. The identification and characterization of this collection represents the most extensive diversity analysis of Fusarium spp. associated with Panama disease. Using multi-gene phylogenetic analyses, I discovered nine distinct genetic lineages with pathogenicity to banana, which were recognised as new phylogenetic species in the Fusarium oxysporum species complex (FOSC), to which new names and taxonomic descriptions were assigned. The complexity and current status of Fusarium wilt disease in banana in Indonesia is also discussed.

In Chapter 3, I expanded the diversity analyses by using whole genomic profiles generated by genotyping-by-sequencing using Diversity Array Technology (DArTseq) markers. Cluster analyses of Indonesian and global isolates revealed the widest genotypic diversity ever reported in Fusarium wilt pathogens of banana. More than half of the genotypes identified are present in Indonesia, suggesting that Fusarium spp. co-evolved with local banana 
varieties. I provide strong evidence that the so-called Tropical Race 4 (TR4) that kills Cavendish varieties, likely emerged from Indonesia, and is still evolving with many local varieties. In contrast, Race 1 isolates, which caused the first epidemic in Gros Michel bananas in the previous century display more genetic diversity. Such precise descriptions of genetic diversity are very important to further explore disease resistance in native and wild banana varieties. The reliability of DArTseq markers was demonstrated by their power to discriminate isolates below the Fusarium spp. level, which provided an unparalleled robustness of the proposed species concept.

Chapter $\mathbf{4}$ focuses on the pathogenicity of the Indonesian collection of Fusarium spp. described in chapter $\mathbf{2}$ and 3. All isolates were phenotyped on Grand Naine, Gros Michel, the wild diploid Musa acuminata ssp. malaccensis (Pahang) and the diploid cultivated variety Pisang Rejang. This resulted in a large database with qualitative and quantitative variation for pathogenicity for the ten identified Fusarium spp. in Indonesia. Interestingly, TR4 isolates mapped to one species that I named Fusarium odoratissimum, whereas Race 1 strains belonged to six species.

Chapter $\mathbf{5}$ describes the discovery of other non-pathogenic Fusarium species hitchhiking with pathogenic Fusarium spp. on banana. Multi-gene phylogenies revealed two new species in the $F$. fujikuroi species complex (FFSC), six new species in the $F$. incarnatumequiseti species complex (FIESC) and one isolate of $F$. longipes in the $F$. sambucinum species complex (FSSC). The latter was never reported to be present in the pseudostem of banana plants. None of these species are pathogenic on banana and hence, these findings give an insight into the endophytic existence of Fusarium spp. in non-host plants and their potential role in the Fusarium wilt disease of banana.

In chapter 6, the findings in all chapters are synthesized in an overarching discussion. The required taxonomic revision of the Fusarium wilt pathogens of banana is discussed with a proposition to place them in the Fusarium of banana complex (FuBC). The adopted approach of identification comprising molecular-based diversity analyses, which excels over phenotyped-based diversity analyses and the evidence of possible sources of genetic variation in these asexual fungi are also discussed. Despite the advances, the FuBC - banana pathosystem lacks a genetic basis and comparative analyses with other formae speciales might therefore be very useful as well as genetic studies in the host. With well-characterized Fusarium species, such studies become meaningful and will contribute to an overall strategy for developing new and resistant banana germplasm. The thesis ends with a complete overview of all cited references. 


\section{Ringkasan}

Pisang merupakan salah satu komoditas buah yang paling banyak dikonsumsi dan merupakan makanan pokok di beberapa negara di dunia. Produksi pisang yang berkelanjutan menjadi sangat penting untuk menjaga ketersediaan buah ini baik di pasar domestik maupun internasional yang juga merupakan penunjang kehidupan jutaan petani kecil. Buah yang paling banyak digemari ini pernah dan masih terancam salah satu penyakit yang sangat merugikan sepanjang sejarah yaitu penyakit layu Fusarium atau Panama disease. Penyakit ini disebabkan oleh jamur tanah yang dikenal dengan Fusarium oxysporum f. sp. cubense (Foc). Strategi utama untuk mengantisipasi persebaran penyakit yang telah menghancurkan ribuan hektar perkebunan pisang di beberapa negara di dunia ini adalah dengan menghasilkan jenis pisang yang tahan penyakit. Sehingga pengetahuan tentang keragaman jamur penyebab penyakit ini menjadi sangat diperlukan. Indonesia merupakan daerah asal dan pusat keragaman pisang. Ratusan jenis pisang liar dan pisang budidaya tumbuh subur diseluruh kepulauannya. Pada umumnya pusat keragaman host/ inang dan agen penyebab penyakit yang menyerangnya berada pada tempat yang sama. Dengan demikian, Indonesia adalah kawasan utama untuk mempelajari keragaman jamur penyebab penyakit Panama disease dimana diduga co-evolution terjadi antara jamur ini dengan inangnya. Disertasi ini menyajikan beberapa studi/ kajian paling informatif pada keragaman genetik dan phylogeny Fusarium spesies yang menyebabkan penyakit layu pada pisang, keragaman genotipik dan pathogenisitasnya, serta Fusarium spp. tidak menyebabkan penyakit.

Bab 1 memaparkan tinjauan pustaka terkini pada pisang dan hubungannya dengan Fusarium yang menyebabkan penyakit. Sejarah domestikasi pisang, produksi dan pentinganya pisang sebagai komoditas buah juga ditinjau. Hal ini kemudian dihubungkan dengan penyakit layu Fusarium sebagai hambatan utama budidaya, sampai kepada pentingnya dan kebutuhan mendesak untuk mempelajari keragaman jamur penyebab penyakit ini di Indonesia.

Bab 2 menjelaskan explorasi penyakit layu Fusarium di Indonesia meliputi 34 lokasi sentra produksi pisang di Indonesia yang ada di pulau Jawa, Flores, Kalimantan, Papua, Sumatra dan Sulawesi. Lebih dari 200 isolat Fusarium berhasil diisolasi dari berbagai jenis pisang lokal yang terserang penyakit. Identifikasi dan karakterisasi koleksi ini menunjukkan analisis keragaman paling luas dan lengkap pada Fusarium spp. yang berasosiasi dengan Panama disease. Dengan menggunakan multi-gene phylogeny analisis saya menemukan sembilan genetic lineage dengan patogenisitas terhadap pisang dan dikenali sebagai phylogenetic species baru di dalam Fusarium oxysporum species complex (FOSC), sehingga nama dan deskripsi taksonomi diberikan pada spesies-spesies tersebut. Kompleksitas dan status terkini dari penyakit layu Fusarium pada pisang di Indonesia juga dibahas pada bab ini.

Pada bab 3, saya mengkaji lebih jauh analisis keragaman menggunakan profil genom yang dihasilkan dari genotyping-by-sequencing menggunakan penanda genetik Diversity Array Technology (DArTseq). Analisis klaster strain-strain asal Indonesia dan dunia 
menghasilkan keragaman genotip yang paling tinggi yang pernah dilaporkan pada jamur penyebab layu Fusarium pada pisang. Lebih dari separuh genotip yang diidentifikasi berasal dari Indonesia, menunjukkan bahwa Fusarium spp. berevolusi bersama dengan beragam pisang lokal. Deskripsi keragaman genetik secara tepat dan akurat sangat penting untuk dapat mengeksplorasi ketahanan penyakit pada pisang-pisang lokal maupun pisang-pisang liar. Keandalan penanda genetik DArTseq ditunjukkan oleh kemampuannya membedakan strainstrain dalam spesies Fusarium sehingga menghasilkan analisis yang kuat untuk konsep spesies yang diusulkan pada Bab 1.

Bab 4 fokus pada patogenisitas strain-strain Fusarium spp. dari Indonesia yang dideskripsikan pada Bab 2 dan Bab 3. Semua strain diuji patogenistasnya pada kultivar pisang Grand Naine, Gros Michel, pisang liar Musa acuminata ssp. malaccensis (Pahang), dan diploid kultivar pisang Rejang. Percobaan ini menghasilkan data yang cukup besar dengan variasi kuantitatif dan kualitatif patogenisitas pada sepuluh spesies Fusarium asal gejala layu panama yang teridentifikasi di Indonesia. Semua ras TR4 terpetakan sebagai satu spesies, $F$. odoratissimum, sedangkan ras 1 terdiri dari enam spesies.

Bab 5 menjelaskan penemuan beberapa Fusarium spesies non-patogen membonceng pada Fusarium spp. patogen pisang pada satu gejala. Multi-gene phylogeny berhasil mengidentifikasi dua spesies baru pada $F$. fujikuroi species complex (FFSC), enam spesies baru pada $F$. incarnatum-equiseti species complex (FIESC) dan satu strain $F$. longipes pada $F$. sambucinum species complex (FSSC). Spesies terakhir yang disebutkan belum pernah dilaporkan ada pada pseudostem pohon pisang. Tidak ada satupun dari spesies ini yang menyebabkan penyakit pada pisang, namun penemuan ini memberikan pengetahuan tentang keberadaan Fusarium spp. endofit serta potensial peranannya pada pisang yang teserang layu Fusarium.

Pada Bab 6, penemuan-penemuan di semua Bab disintesis dalam sebuah pembahasan yang menyeluruh. Kebutuhan revisi taksonomi patogen layu Fusarium pada pisang dibahas dengan sebuah usulan untuk menempatkannya pada Fusarium of banana complex (FuBC). Pendekatan identifikasi yang digunakan meliputi analisis keragaman berbasis molekuler yang mampu mengungguli analisis keragaman berbasis fenotip serta bukti-bukti kemungkinan sumber keragaman genetik yang dapat terjadi pada jamur aseksual ini juga dibahas. Disamping kemajuan yang telah dicapai, dasar-dasar genetik interaksi pathosystem antara FuBC - pisang belum diketahui dan komparatif analisis dengan formae specialis lain akan sangat bermanfaat termasuk dasar-dasar genetik pada inang. Dengan karakterisasi yang sangat baik yang telah diketahui pada Fusarium spp., studi seperti itu akan menjadi sangat bermanfaat dan dapat digunakan untuk mengembangkan jenis pisang baru dan tahan terhadap penyakit. 


\section{Samenvatting}

De banaan is een van de meest geconsumeerde fruitsoorten en tegelijkertijd een basisvoedsel in veel landen. De instandhouding van de bananenproductie is belangrijk om lokale en internationale markten te voorzien zodat miljoenen kleine boeren in hun levensonderhoud kunnen voorzien. Het geliefdste fruit werd en wordt echter verwoest door een van de bedreigendste ziekten in zijn historie; Fusarium verwelkingsziekte of Panamaziekte. De ziekte wordt veroorzaakt door een reeks bodemgebonden schimmels, die voorheen bekend stonden onder de gezamenlijke naam Fusarium oxysporum f.sp. cubense (Foc). De eerste strategie om de huidige pandemie, die reeds duizenden hectaren bananenplantages in vele landen heeft verwoest, te beheersen is het ontwikkelen van resistente rassen. Daarom is meer kennis van de schimmels die deze ziekte veroorzaken onmisbaar. Indonesië is het belangrijkste oorsprongsgebied van banaan waar honderden wilde soorten en variëteiten in de gehele archipel voorkomen en worden geteeld. In het algemeen overlappen de oorsprongsgebieden van gewassen en hun pathogenen. Daarom is Indonesië een van de primaire gebieden om de diversiteit van de schimmels die Panamaziekte veroorzaken te bestuderen vanwege hun co-evolutie met de waardplant. Dit proefschrift is een van de informatiefste studies naar de genetische diversiteit en de fylogenie van Fusarium soorten die worden geassocieerd met Panamaziekte. Het draagt bij aan de kennis en de systematiek van Fusarium soorten die pathogeen zijn op banaan, door de beschrijving van hun genetische diversiteit en pathogeniteit, en beschrijft ook andere soorten die banaan normaliter niet aantasten maar die meeliften met pathogene soorten in het vaatsysteem van aangetaste planten.

In hoofdstuk 1 beschrijf ik de stand van zaken in het Fusarium onderzoek bij de aanvang van het onderzoek. De geschiedenis en de domesticatie van banaan komen naar voren, en daarnaast wordt het belang van het gewas als handelsgewas besproken. Dit wordt vervolgens in verband gebracht met Fusarium verwelkingsziekte als een van de belangrijkste beperkingen, uitlopend op het belang en de noodzaak om de diversiteit van de daaraan ten grondslag liggende schimmels in Indonesië te onderzoeken.

Hoofdstuk 2 beschrijft een verzamelexpeditie waarin ziekte planten werden bemonsterd in 34 verschillende locaties in de belangrijkste bananen producerende gebieden op Java, Flores, Kalimantan, Papoea, Sumatra en Sulawesi. Meer dan 200 Fusarium isolaten werden verkregen uit vele lokale rassen die door de ziekte waren aangetast. De identificatie en karakterisering van deze collectie is een van de uitgebreidste diversiteitsanalyses van Fusarium soorten die met Panamaziekte in verband worden gebracht. Door gebruik te maken van fylogenetische analysen die werden uitgevoerd op basis van meerdere genen ontdekten wij negen onderscheiden genetische lijnen met pathogeniteit voor banaan, die wij vervolgens hebben beschreven als nieuwe soorten van het Fusarium oxysporum soorten complex (FOSC) met de daarbij behorende namen en beschrijvingen. Daarnaast wordt aandacht besteed aan de complexiteit, de huidige omvang en het belang van Panamaziekte in Indonesië. 
In hoofdstuk 3, heb ik de voorgaande diversiteitsanalyse uitgebreid door gebruik te maken van sequentietechnieken gekoppeld aan Diversity Array Technology (DArTSeq) waarmee ik profielen van het gehele genoom kon samenstellen. Door dit te combineren met een collectie wereldwijde isolaten resulteerde dit in een van de uitgebreidste diversiteitsanalyses van pathogenen die Fusarium verwelkingsziekte in banaan veroorzaken. Meer dan de helft van de geïdentificeerde genotypen zijn aanwezig in Indonesië, hetgeen suggereert dat deze Fusarium soorten zijn ontstaan door de co-evolutie met lokale bananenvariëteiten. Wij leveren sterke aanwijzingen dat het zogenaamde Tropische fysio 4 (TR4) dat Cavendish bananen doodt waarschijnlijk in Indonesië is ontstaan en zich nog steeds verder ontwikkeld in vele lokale rassen. In tegenstelling daarmee vertonen fysio 1 isolaten, die in de vorige eeuw de eerste epidemie in "Gros Michel' veroorzaakten, een grotere diversiteit. Het precies beschrijven van genetische diversiteit is van belang voor het opsporen van resistentie in inheemse rassen en wilde soorten. De betrouwbaarheid van DArTSeq merkers werd duidelijk door de hoge resolutie waarmee zij in staat zijn om isolaten binnen soorten te onderscheiden. Dit legt een ongeëvenaarde en robuuste basis onder het voorgestelde soortsconcept.

Hoofdstuk 4 concentreert zich op de pathogeniteit van de collectie Indonesische Fusarium isolaten die in banaan werden aangetroffen. Alle isolaten werden getest op 'Grand Naine', 'Gros Michel', de wilde diploïde Musa acuminata spp. malaccensis (Pahang) en de geteelde diploïde variëteit Pisang Rejang. Dit resulteerde in een grote dataset met kwalitatieve en kwantitatieve pathogeniteitsgegevens van de 10 geïdentificeerde Fusarium soorten in Indonesië. Het was interessant te zien dat de TR4 isolaten tot één soort behoren, die wij Fusarium odoratissimum hebben genoemd, terwijl de fysio 1 isolaten verdeeld zijn over zes soorten.

Hoofdstuk 5 beschrijft de ontdekking dat andere Fusarium soorten met de stammen meeliften die banaan wel kunnen aantasten. Genetische analysen op basis van meerdere genen laten zien dat twee van deze nieuwe soorten tot het $F$. fujikuroi soortencomplex (FFSC) behoren, zes nieuwe soorten maken onderdeel uit van het $F$. incarnatum-equiseti soorten complex (FIESC) en een $F$. longipes isolaat behoort tot het $F$. sambucinum soorten complex (FSSC). Deze laatste soort is nooit eerder beschreven in de pseudostam van bananen. Geen van deze nieuwe soorten is pathogeen op banaan en daarom geven deze resultaten inzicht in het epidemiologische en polyfage gedrag van Fusarium soorten op andere plantensoorten en de mogelijke rol ervan bij de ontwikkeling van Fusarium verwelkingsziekte in banaan.

In Hoofdstuk 6 worden alle resultaten aaneengesmeed in een overkoepelende discussie. De benodigde taxonomische revisie van pathogenen die Fusarium verwelkingsziekte in banaan veroorzaken wordt bediscussieerd en er wordt voorgesteld die isolaten onder te brengen in het nieuwe Fusarium van banaan complex (FuBC). De gebruikte benadering waarin gebruik werd gemaakt van moleculaire diversiteitsanalysen, die beter zijn dan op phenotypering gebaseerde methoden, en de mogelijke oorzaak van de gevonden genetische diversiteit in deze asexuele schimmels worden ook bediscussieerd. Ondanks deze inzichten ontbeert het FuBC-banaan pathosysteem een genetische basis en vergelijkende 
analysen met andere formae speciales kunnen daarom zeer waardevol zijn naast genetisch onderzoek aan de waardplant. Met goed beschreven Fusarium soorten winnen dergelijke studies aan waarde en dragen zij bij aan een alomvattende strategie om nieuwe en resistente bananenrassen te ontwikkelen. Het proefschrift eindigt met een compleet overzicht van de gebruikte literatuur. 


\section{Curriculum vitae}

Nani Maryani was born on July $29^{\text {th }} 1983$ in Tangerang, Indonesia and received her primary education in Jakarta. She continued her education at Bogor Agricultural University (IPB) and graduated (2005) in Biology with a specialization in Mycology and a BSC thesis on the formulation of Acremonium infected Aquilaria plants to produce Agarwood (Gaharu), under the supervision of Dr. Gayuh Rahayu.

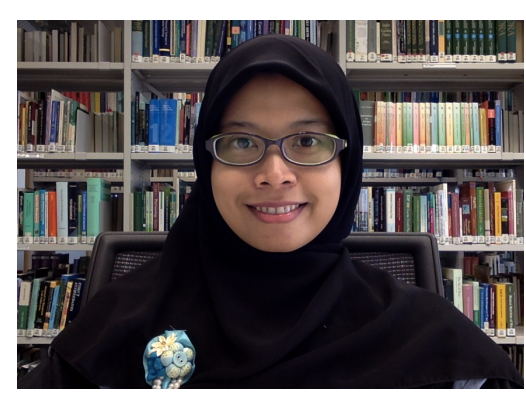

After graduation, she joined the Laboratory of Mycology, department of Biology, IPB, and continued the Acremonium research. In 2006, she worked as a biology teacher for high school students at the School of Universe, Bogor. In 2007, she took a short training on Teaching and Pedagogy at the University of Ibn Khaldun, Bogor. In 2008, she joined the department of Biology Education, Faculty of Education and Teacher Training, University of Sultan Ageng Tirtayasa (UNTIRTA), Banten, Indonesia. In 2010, she commenced a Master course in Microbiology at IPB and in 2011 she continued her Master 2 Research at the Institute Nationale des Science Appliqués (INSA) in Toulouse, France. She studied the phenotypic variation of Xanthomonas campestris pv. campestris, the causal agent of Black Rot disease of cabbage, for her MSc thesis in the group of Prof. Matthew Arlat (LIPM INRA Toulouse).

By the end of 2013, she continued her study as a PhD at Wageningen University and Research in the Scientific Program Indonesia Netherlands of the Royal Netherlands Academy of Arts and Sciences (KNAW-SPIN), under the supervision of Prof. Gert Kema. The results of her project on exploring Fusarium wilt pathogens of banana in Indonesia are presented in this book. She will continue her career as a researcher and lecturer in the department of Biology Education, UNTIRTA, Banten, Indonesia and hopes to continue her discovery research on Fusarium and banana in Indonesia. 


\section{List of Publications}

Maryani N., Lombard L., Poerba Y.S., Subandiyah S., Crous P.W., Kema G.H.J. (2019). Phylogeny and genetic diversity of the banana Fusarium wilt pathogen Fusarium oxysporum f. sp. cubense in the Indonesian centre of origin. Studies in Mycology 92: 155-194. https://doi.org/10.1016/j.simyco.2018.06.003.

Maryani N., Sandoval-Dennis M., Lombard L., Crous P.W., Kema G.H.J. (2019). New endemic Fusarium species hitchhiking with pathogenic Fusarium strains causing Panama disease in small-holder banana plots in Indonesia. Submitted

Maryani N., Seidl M.F., Crous P.W., Kema G.H.J. (2019). Genotyping-by-sequencing reveals extensive genotypic diversity among sympatric Fusarium wilt pathogens of banana in Indonesia. Submitted

Maryani N., Ahmad F., Keizer L.C.P., Crous P.W., Kema G.H.J. (2019). Pathogenic diversity of Indonesian Fusarium wilt pathogens in wild and cultivated bananas. In submission.

\section{In books of abstracts}

Maryani N., Ahmad F., Schmidt S.M., Lombard L., Poerba Y.S., Crous P.W., Kema G.H.J. (2015). Diversity of Fusarium oxysporum $\mathrm{f}$. sp. cubence isolated from local banana cultivars in Indonesia. In Book of abstracts of 28th Fungal Genetics Conference, 17-22 March 2015, Pacific Grove, CA, USA.

Maryani N., Lombard L., Poerba Y.S., Subandiyah S., Crous P.W., Kema G.H.J. (2016). Phylogenetic diversity of Fusarium oxysporum f. sp. cubense in Indonesia. In Book of abstracts of $13^{\text {th }}$ European Conference on Fungal Genetics (ECFG13), 3-6 April 2016, Paris, France.

Maryani N., Seidl M.F., Meijer H.J.G., Poerba Y.S., Subandiyah S., Crous P.W., Kema G.H.J. (2016). Fusarium oxysporum f. sp. cubense in Indonesia: Diversity and Pathogenicity. In Book of abstracts of Wageningen Indonesian Scientific Exposure (WISE), 28 October 2016, Wageningen, NL.

Maryani N., Seidl M.F, Meijer H.J.G., Kema G.H.J. (2018). Genetic variation of Indonesian Fusarium oxysporum f. sp. cubense isolates and their pathogenicity on wild and cultivated banana species. In Book of abstracts of $14^{\text {th }}$ European Conference on Fungal Genetics (ECFG), 25-28 February 2018, Haifa, Israel. 


\title{
Education Statement of the Graduate School \\ Experimental Plant Sciences
}

\author{
Issued to: Nani Maryani \\ Date: 29 October 2018 \\ Group: Laboratory of Phytopathology \\ University: Wageningen University \& Research
}

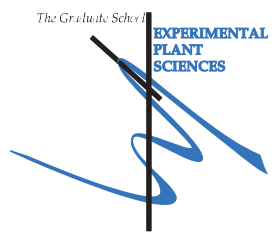

\author{
1) Start-up phase \\ - First presentation of your project \\ Genome wide diversity analyses of Fusarium oxysporum f.sp. cubense in Indonesia \\ - Writing or rewriting a project proposal \\ Genome wide diversity analyses of Fusarium oxysporum f.sp. cubense in Indonesia \\ Writing a review or book chapter \\ MSc courses \\ Laboratory use of isotopes
}

date

31 Mar 2014

31 May 2014

2) Scientific Exposure

- EPS PhD student days

EPS PhD student day 'Get2Gether', Soest, NL

EPS PhD student day 'Get2Gether', Soest, NL

Subtotal Start-up Phase

$7.5^{*}$

- EPS theme symposia

EPS Theme 4 Symposium 'Genome Biology', Wageningen, NL

EPS Theme 2 Symposium 'Interaction between plants and biotic agents' \& Willie Commelin Scholten Day, Amsterdam, NL

EPS Theme 4 Symposium 'Genome Biology', Wageningen, NL

EPS Theme 2 Symposium 'Interactions between plants and biotic agents' \& Willie Commelin Scholten

Day, Leiden, NL

EPS Theme 2 Symposium 'Interactions between plants and biotic agents' \& Willie Commelin Scholten

Day, Wageningen, NL

EPS Theme 2 Symposium 'Interactions between plants and biotic agents' \& Willie Commelin Scholten

Day, Amsterdam, NL

EPS Theme 1 Symposium 'Developmental Biology of Plants', Wageningen, NL

- National meetings (e.g. Lunteren days) and other National Platforms

Annual meeting 'Experimental Plant Sciences', Lunteren, NL

Annual meeting 'Experimental Plant Sciences', Lunteren, NL

Annual meeting 'Experimental Plant Sciences', Lunteren, NL

- Seminars (series), workshops and symposia

CBS Symposium '2nd International Workshop on Ascomycetes Systematics', Amsterdam, NL

CBS Symposium 'Fungi and Global Challenges', Amsterdam, NL

Wageningen PhD Council PhD Symposium 'Diversity in Science', Wageningen, NL

31st KNPV Fusarium Meeting, Utrecht, NL

Wageningen Indonesian Scientific Exposure (WISE), Wageningen, NL

Westerdijk Institute Symposium 'Cryptic Speciation in Classifications', Utrecht, NL

- Seminar plus

- International symposia and congresses

Indonesian Student Scientific Conference (ISSC2014), Wageningen, NL

28th Fungal Genetics Conference, Pacific Grove, CA, USA

13th European Conference on Fungal Genetics (ECFG13), Paris, France

14th European Conference on Fungal Genetics (ECFG14), Haifa, Israel

- Presentations

Talk: Indonesian Scientific Students Conference (ISSC2014), Wageningen, NL

Talk: International Conference on Sustainable Agriculture and Natural Resources Management,

Surabaya, Indonesia

Talk: EPS Theme 2 Symposium \& Willie Commelin Scholten Day, Leiden, NL

Talk: CBS Symposium 'Fungi and Global Challenges', Amsterdam, NL

Talk: 31st KNPV Fusarium Meeting, Utrecht, NL

Talk: Westerdijk Institute Symposium 'Cryptic Speciation in Classifications', Utrecht, NL

Talk: 14th European Conference on Fungal Genetics (ECFG14), Haifa, Israel

Poster: Wageningen Banana Day, Wageningen, NL

Poster: 28th Fungal Genetics Conference, Pacific Grove, CA, USA

Poster: 13th European Conference on Fungal Genetics, Paris, France

Poster: Wageningen Indonesian Scientific Expoosure (WISE), Wageningen, NL

$\underline{\text { date }}$

29-30 Jan 2015

09-10 Feb 2017

13 Dec 2013

25 Feb 2014

03 Dec 2014

22 Jan 2016

23 Jan 2017

24 Jan 2018

30 Jan 2018

14-15 Apr 2014

13-14 Apr 2015

11-12 Apr 2016

22-24 Apr 2015

14-15 Apr 2016

26 Apr 2016

26 Oct 2016

28 Oct 2016

01 Sep 2017

22 Nov 2014

17-22 Mar 2015

03-06 Apr 2016

25-28 Feb 2018

22 Nov 2014

06-07 Aug 2015

22 Jan 2016

14 Apr 2016

26 Oct 2016

01 Sep 2017

28 Feb 2018

18 Nov 2014

17-22 Mar 2015

03-06 Apr 2016

28 Oct 2016

- IAB interview

Excursions

PhD Excursion, visit to breeding company Enza Zaden, Enkhuizen, NL

12 Jun 2015

PhD Excursion, visit to company Tomato World, Honselersdijk, NL 


\section{3) In-Depth Studies}

EPS courses or other PhD courses

Course 'Fungal Biodiversity', Utrecht, NL

Postgraduate course 'Introduction to R for Statistical Analysis', Wageningen, NL

03-14 Feb 2014

Spring School 'Host-Microbe Interatomics', Wageningen, NL

COMREC Bioinformatics Course, Wageningen, NL

Postgraduate course 'Genome Assembly', Wageningen, NL

Graduate course 'Phylogenetics: Principles \& Methods', Wageningen, NL

Plant Pathogenomics Training School of the COST Action SUSTAIN, Norwich, UK

Journal club

Individual research training

\section{4) Personal development}

- Skill training courses

Course 'Social Dutch 1 - level A1', Wageningen, NL

Course 'Project and Time management', Wageningen, NL

PhD Competence Assessment, Wageningen, NL

Course 'Techniques for Writing and Presenting a Scientific Paper, Wageningen, NL

EPS Introduction Course, Wageningen, NL

Course 'Information Literacy PhD including End-Note Introduction', Wageningen, NL

Course 'Scientific Writing', Wageningen, NL

Workshop 'Reviewing a Scientific Paper', Wageningen NL

Last stretch of your PhD, Wageningen, NL

Adobe InDesign Essential Training, Wageningen, NL

19-20 May 2014

02-04 Jun 2014

04-06 Feb 2015

28-29 Apr 2015

17-19 May 2016

03-07 Apr 2017

Organisation of $\mathrm{PhD}$ students day, course or conference

- Membership of Board, Committee or PhD council 
The research described in this thesis was financially supported by the Scientific Program between Indonesia and the Netherlands (SPIN) of by the Royal Netherlands Academy of Arts and Sciences (KNAW) and the Directorate General of Higher Education (DIKTI), Ministry of Research, Technology and Higher Education, Indonesia.

\section{Cover design:}

Nani Maryani, drawn by Endah Purbayanti

\section{Layout design:}

Nani Maryani and Loes Kema

\section{Printed by:}

GVO drukkers \& vormgevers, Ede, The Netherlands 


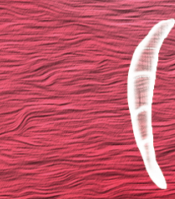

d

$p=p=1$

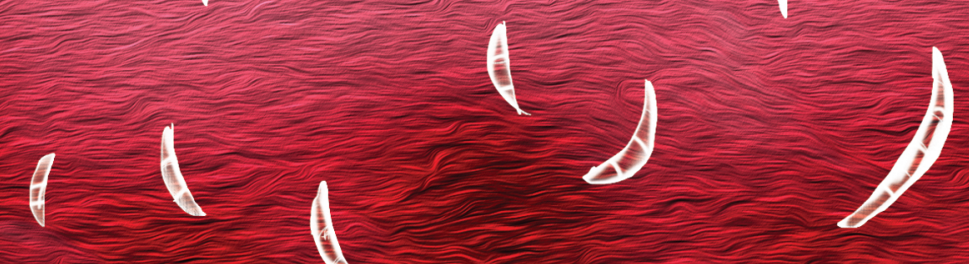

d

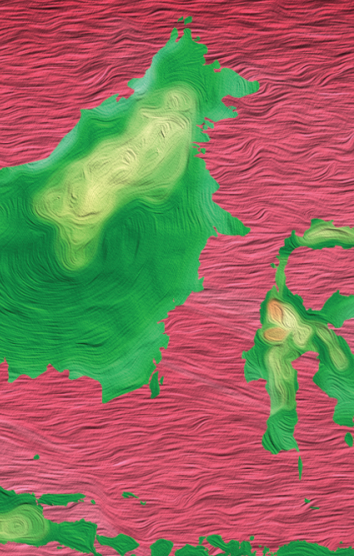

हs
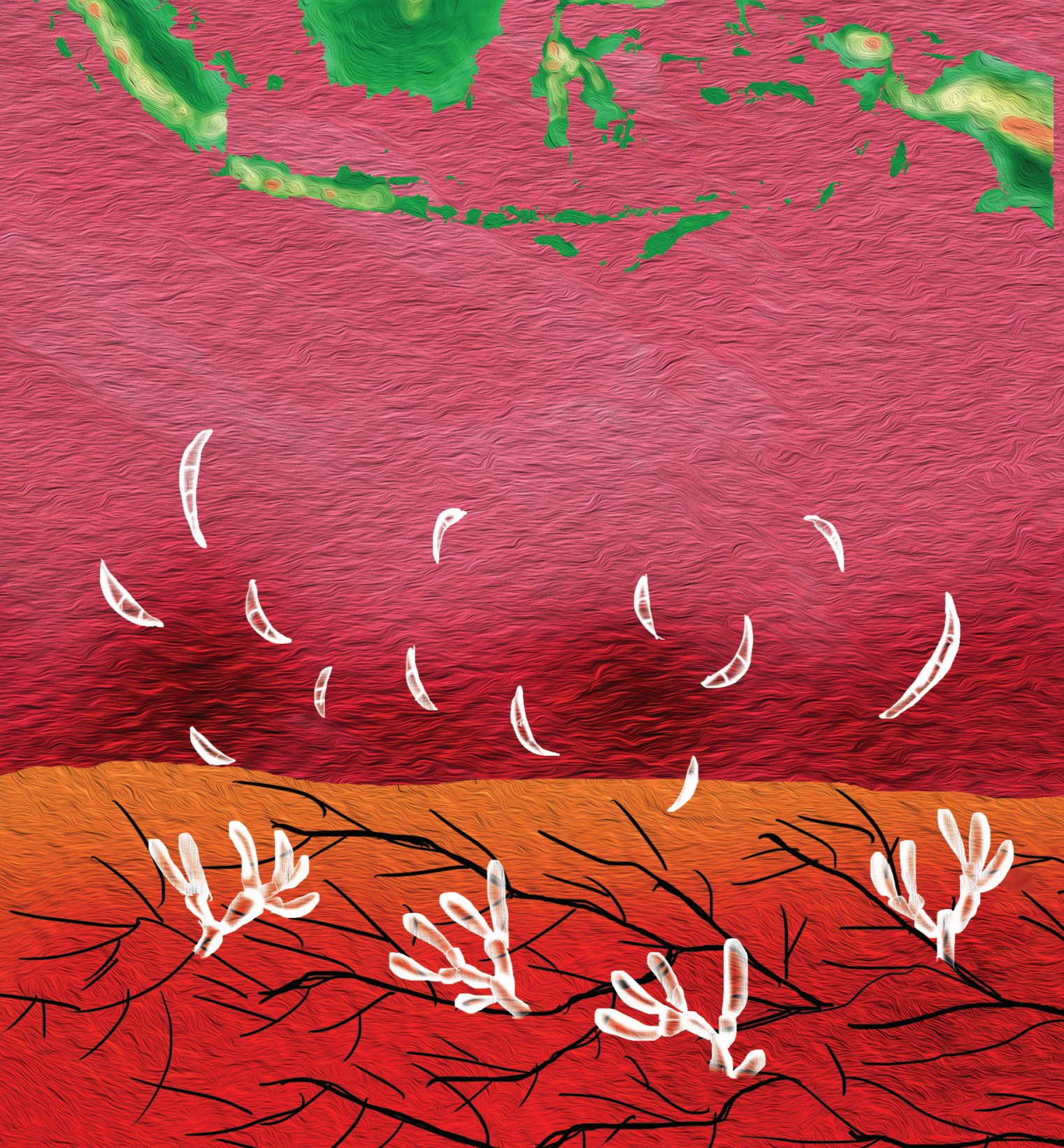